UNIVERSIDADE DE SÃO PAULO

ESCOLA DE ENGENHARIA DE SÃO CARLOS

DEPARTAMENTO DE ENGENHARIA DE ESTRUTURAS

VANESSA DOMICIANO FELÍCIO

\title{
ANÁLISE EXPERIMENTAL DE VIGAS DE AÇO E MISTAS DE AÇO E CONCRETO PARCIALMENTE REVESTIDAS EM SITUAÇÃO DE INCÊNDIO
}

SÃO CARLOS 



\title{
ANÁLISE EXPERIMENTAL DE VIGAS DE AÇO E MISTAS DE AÇO E CONCRETO PARCIALMENTE REVESTIDAS EM SITUAÇÃO DE INCÊNDIO
}

\author{
VERSÃO CORRIGIDA \\ A versão original encontra-se na Escola de Engenharia de São Carlos
}

Dissertação apresentada ao Departamento de Engenharia de Estruturas da Escola de Engenharia de São Carlos, Universidade de São Paulo, como parte dos quesitos necessários para obtenção do título de Mestre em Engenharia Civil (Estruturas).

Orientador: Prof. Dr. Jorge Munaiar Neto 
AUTORIZO A REPRODUÇÃO TOTAL OU PARCIAL DESTE TRABALHO, POR QUALQUER MEIO CONVENCIONAL OU ELETRÔNICO, PARA FINS DE ESTUDO E PESQUISA, DESDE QUE CITADA A FONTE.

Ficha catalográfica elaborada pela Biblioteca Prof. Dr. Sérgio Rodrigues Fontes da EESC/USP com os dados inseridos pelo(a) autor(a).

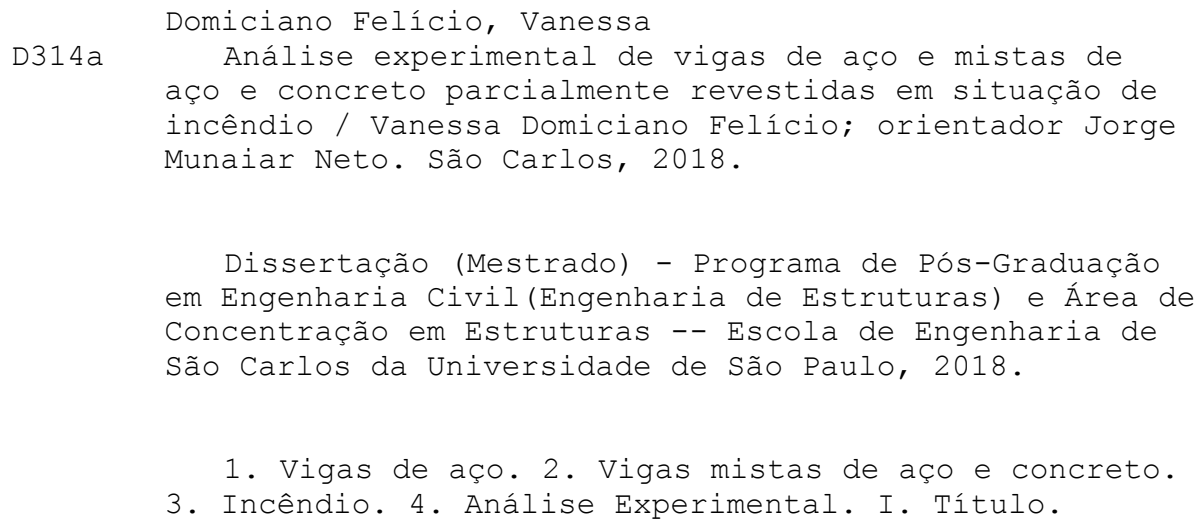

Eduardo Graziosi Silva - CRB - 8/8907 


\section{FOLHA DE JULGAMENTO}

Candidata: Engenheira VANESSA DOMICIANO FELÍCIO.

Título da dissertação: "Análise experimental de vigas de aço e mistas de aço e concreto parcialmente revestidas em situação de incêndio".

Data da defesa: $21 / 11 / 2018$.

Comissão Julgadora:

Prof. Associado Jorge Munaiar Nefo (Orientador) (Escola de Engenharia de São Carlos/EESC)

Prof. Dr. Armando Lopes Moreno Junior (Universidade Estadual de Campinas/UNICAMP)

Profa. Dra. Silvana de Nardin (Universidade Federal de São Carlos/UFSCar)

Coordenador do Programa de Pós-Graduação em Engenharia Civil (Engenharia de Estruturas):

Prof. Titular Humberło Breves Coda

Presidente da Comissão de Pós-Graduação: Prof. Associado Luís Fernando Cosía Alberto
Resultado:
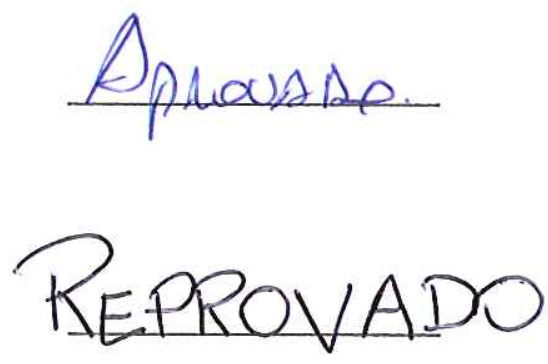

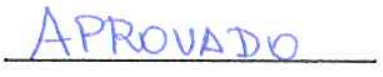



Aos meus pais, com amor e gratidão. Ao meu querido irmão, pelo amor e amizade. Serei sempre grata por vocês em minha vida. 



\section{AGRADECIMENTOS}

Agradeço a Deus, pelo dom da vida, por me iluminar e guiar meus passos.

Aos meus pais, Antônio e Hélia, pelo exemplo de vida e amor incondicional.

Ao meu irmão Vinícius pela amizade e companheirismo.

Ao meu orientador, Prof. Dr. Jorge Munaiar Neto, por sua atenção, orientação e prontidão.

Ao Fábio Rocha, pela ajuda indispensável na realização desse trabalho, bem como os funcionários do Laboratório de Estruturas.

Ao Departamento de Estruturas pelas condições de realização desse trabalho.

À Terceira Igreja Batista em Varginha por sempre me apoiar, lembrarem de mim e me sustentar pela oração.

Aos amigos de Ouro Preto, em especial ao PET Civil/UFOP, Maria Luiza, Sâmyla e Luhann, pela amizade que não mudou, independente da distância.

Aos amigos que São Carlos me deu e sempre lembrarei com carinho, em especial a Felipi Pablo e Tiago Morkis.

Ao Conselho Nacional de Desenvolvimento Científico e Tecnológico (CNPq) pela concessão da bolsa durante o mestrado. 

"Sê forte e corajoso; não temas, nem te espantes, porque o SENHOR, teu Deus, é contigo por onde quer que andares."

Josué 1:9 



\section{RESUMO}

FELÍCIO, V.D. Análise experimental de vigas de aço e mistas de aço e concreto parcialmente revestidas em situação de incêndio. 2018. 148 p. Dissertação (Mestrado em Engenharia Civil (Estruturas)) - Escola de Engenharia de São Carlos, Universidade de São Paulo, São Carlos, 2018.

Sistemas mistos de aço e concreto são aqueles em que o elemento de aço trabalha estruturalmente em conjunto com o concreto. Essa associação dos materiais resulta numa melhor utilização de ambos os materiais tanto quanto à capacidade resistente, quanto em caráter construtivo, funcional e estético. O presente trabalho tem como finalidade a análise de vigas de aço e mistas de aço e concreto parcialmente revestidas em situação de incêndio. Esse estudo tem grande importância tendo em vista os incidentes com altas temperaturas em edificações ocorridos ao longo dos anos. $\mathrm{O}$ aumento de temperatura nas estruturas é um efeito nocivo, pois prejudica a rigidez e a resistência dos materiais, podendo levar estruturas ao colapso. As análises das vigas mistas aço e concreto parcialmente revestidas em situação de incêndio foram feitas através de análises experimentais que foram realizadas no forno horizontal à gás do Laboratório de Engenharia de Estruturas da EESC/USP. Foram realizados ensaios de flexão em pontos em altas temperaturas e a variável nos ensaios foi o fator de carga aplicado no meio do vão das vigas. Foi possível comparar o comportamento das vigas metálica e mistas, bem como as temperaturas em vários pontos ao longo do elemento por meio de termopares colocados em pontos estratégicos. Transdutores de deslocamento também foram usados para saber o valor de deslocamento nos apoios e no meio do vão das vigas. Uma análise térmica bidimensional através do ABAQUS também foi feita para comparação de resultados. Conclui-se que para uma mesma carga aplicada os deslocamentos foram mais expressivos nos ensaios das vigas em situação de incêndio se comparados aos valores obtidos nos ensaios à temperatura ambiente, observou-se o efeito benéfico do revestimento de concreto ao perfil metálico, responsável por um ganho expressivo de resistência ao fogo quando comparado aos elementos puramente metálicos e por fim obteve-se boa concordância entre as temperaturas encontradas por modelagem numérica através do ABAQUS e dos ensaios experimentais realizados.

Palavras-chave: Vigas de aço. Vigas mistas de aço e concreto. Incêndio. Análise experimental. 



\begin{abstract}
FELÍCIO, V.D. Experimental analysis partially encased composite steel-concrete beams in fire. 2018. 148 p. Dissertation (M. Sc. in Civil Engineering (Structures)) - School of Engineering of São Carlos, University of São Paulo, São Carlos, 2018.
\end{abstract}

Composite steel and concrete systems are those in which the steel element works structurally in conjunction with the concrete. This association of the materials results in a better use of both materials as much as the resistant capacity, as well as in a constructive, functional and aesthetic character. The present work has the purpose of analyzing steel beams and mixed steel and concrete partially coated in a fire situation. This study has great importance in view of the incidents with high temperatures in buildings that have occurred over the years. The increase in temperature in the structures is a harmful effect, as it impairs the rigidity and the resistance of the materials, which can lead to collapse structures. The analyzes of the composite steel and concrete composite beams in a fire situation were made through experimental analyzes that were carried out in the horizontal gas furnace of the Laboratory of Structural Engineering of EESC / USP. Bending tests were performed on points at high temperatures and the variable in the tests was the load factor applied in the middle of the span of the beams. It was possible to compare the behavior of the metallic and composite beams as well as the temperatures at various points along the element by means of thermocouples placed at strategic points. Displacement transducers were also used to know the displacement value in the supports and in the middle of the span of the beams. A two-dimensional thermal analysis through ABAQUS was also done for comparison of results. It was concluded that for the same applied load the displacements were more expressive in the tests of the beams in the fire situation compared to the values obtained in the tests at room temperature, the beneficial effect of the concrete coating was observed on the metallic profile, responsible for a an expressive gain of fire resistance when compared to the purely metallic elements and finally a good agreement was obtained between the temperatures found by numerical modeling through ABAQUS and the experimental tests performed.

Keywords: Steel beams. Mixed steel-concrete beam. Fire. Experimental analysis. 



\section{SUMÁRIO}

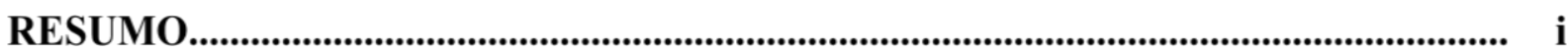

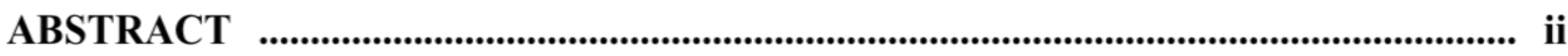

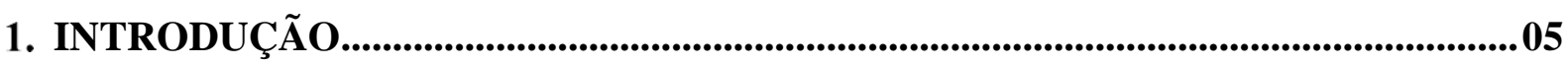

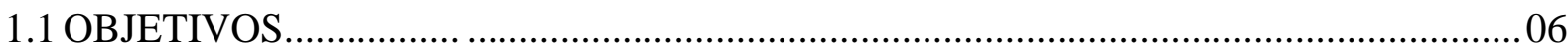

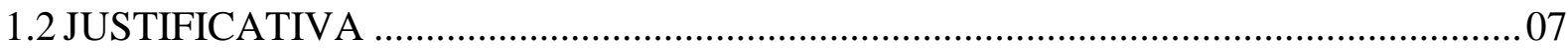

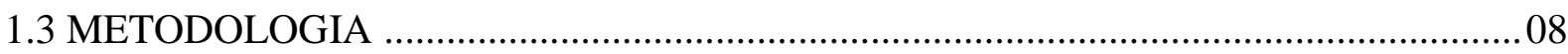

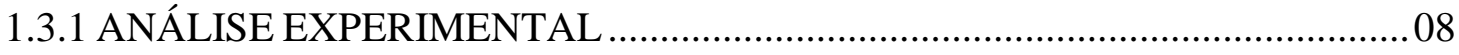

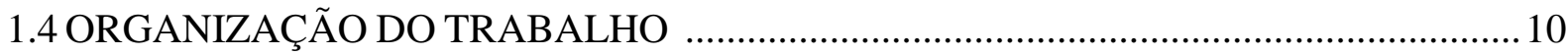

2 VIGAS MISTAS DE AÇO E CONCRETO ........................................................................13

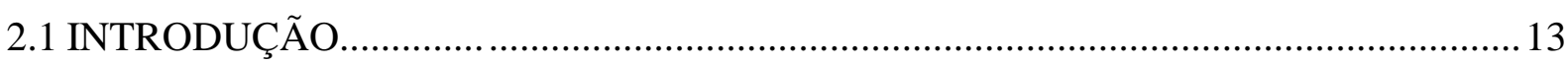

2.2 EFEITO DO CONCRETO ENTRE AS MESAS NO COMPORTAMENTO

ESTRUTURAL DE VIGAS FLETIDAS À TEMPERATURA AMBIENTE ................16

2.3 VIGAS MISTAS PARCIALMENTE REVESTIDAS EM SITUAÇÃO DE INCÊNDIO 20

3 ANÁLISE EXPERIMENTAL 39

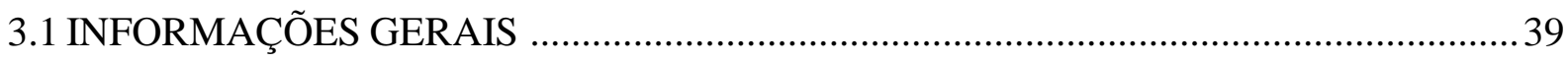

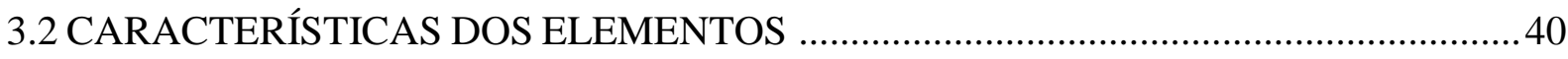

3.3 CONCRETAGEM, MOLDAGEM, ADENSAMENTO E CURA ……………………........42

3.4 CARACTERIZAÇÃO DOS MATERIAIS .................................................................... 46

3.4.1 REFERENTE AO CONCRETO UTILIZADO …………………………........ 46

3.4.2 REFERENTE AO AÇO DO PERFIL DA VIGA …………………………....... 48

3.4.3 REFERENTE AS BARRAS DE AÇO DA ARMADURA ……………………..... 49

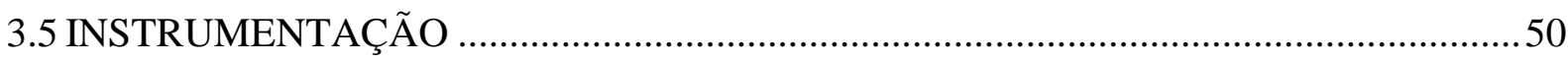

3.5.1 ENSAIO EM TEMPERATURA AMBIENTE …………………………….......50

3.5.2 ENSAIO À TEMPERATURA ELEVADA ……………………………….........

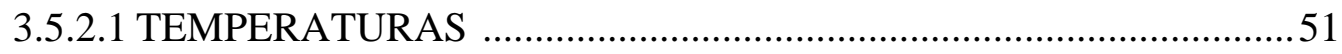

3.5.2.2 MONITORAMENTO DE DESLOCAMENTOS …………………......53

3.5.2.1 APLICAÇÃO DAS FORÇAS ………………………………………....54

3.6 RESULTADOS E DISCUSSÕES REFERENTES AOS ENSAIOS REALIZADOS .........54

3.6.1 RESULTADOS REFERENTES AO ENSAIO A TEMPERATURA

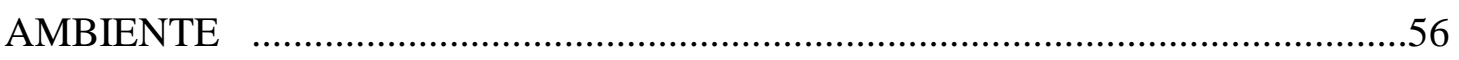

3.6.1.1 VIGA DE AÇO ISOLADA ……………………………………….... 56 
3.6.1.2 VIGA MISTA DE AÇO E CONCRETO PARCIALMENTE

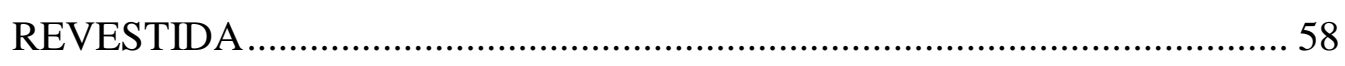

3.6.2 RESULTADOS REFERENTES AOS ENSAIOS EM TEMPERATURAS

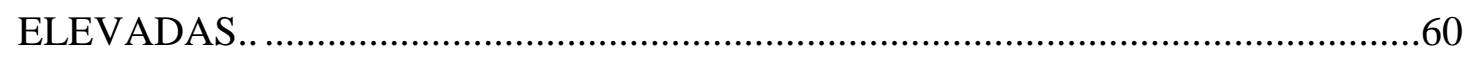

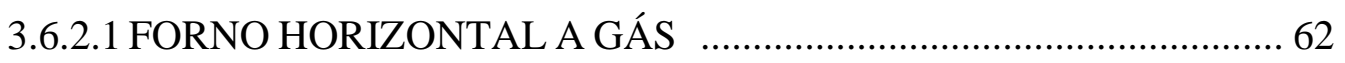

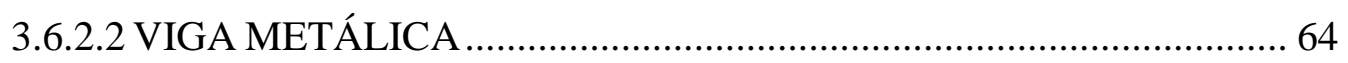

3.6.2.3 VIGA MISTA DE AÇO E CONCRETO PARCIALMENTE

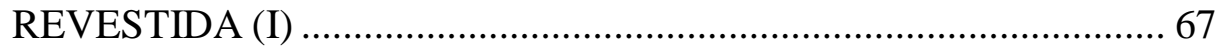

3.6.2.4 VIGA MISTA DE AÇO E CONCRETO PARCIALMENTE

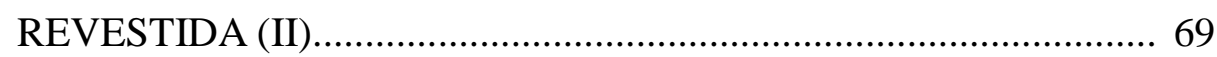

3.6.2.5 VIGA MISTA DE AÇO E CONCRETO PARCIALMENTE

REVESTIDA (III) ................................................................... 72

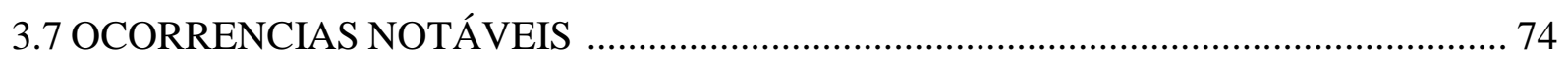

3.8 COMPARAÇÃO ENTRE CURVAS DE INCÊNDIO:

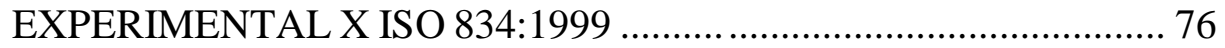

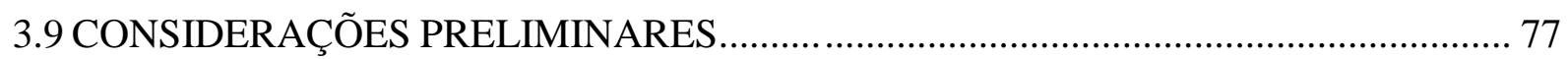

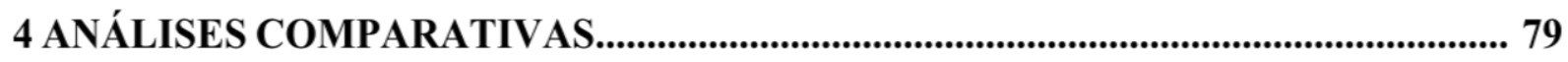

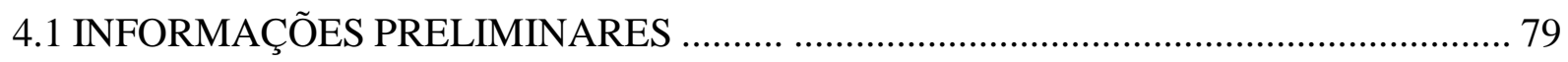

4.2 CÁlCULO CARGA MÁXIMA TEÓRICA PARA A VIGA METÁLICA ….................... 80

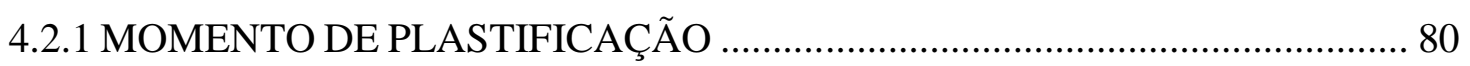

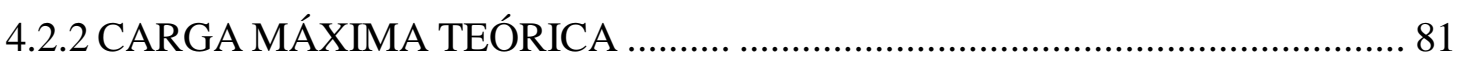

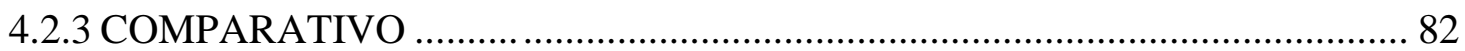

4.3 CALCULO CARGA MÁXIMA TEÓRICA PARA A VIGA MISTA DE AÇO E

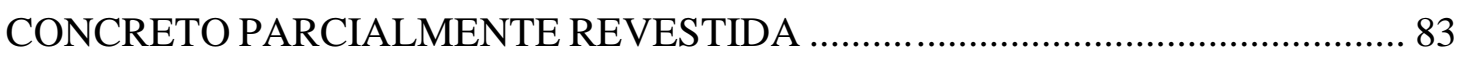

4.3.1 VALORES A SEREM CONSIDERADOS PARA OS CÁLUCLOS

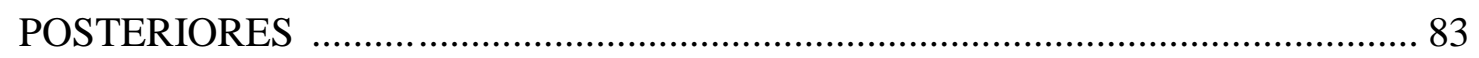

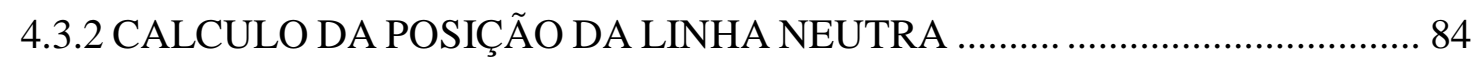

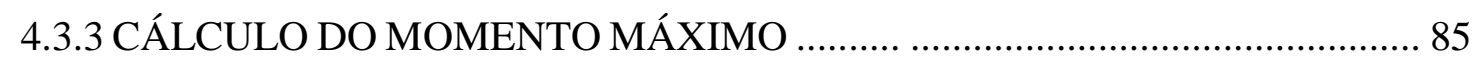

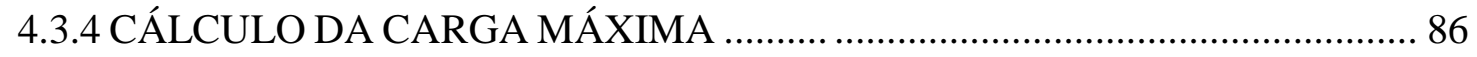

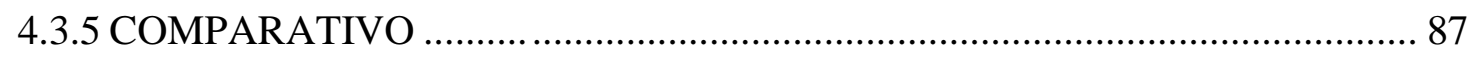

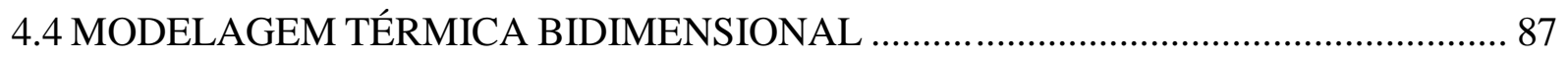

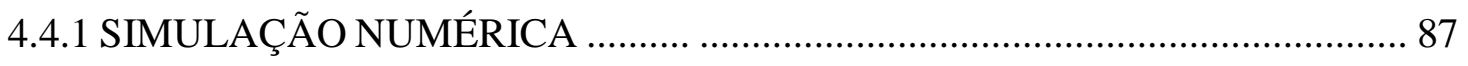

4.4.2 PROPRIEDADES TÉRMICAS DO CONCRETO ............................................ 88 
4.4.3 PROPRIEDADES TÉRMICAS DO AÇO ................................................... 91

4.4.4 RESULTADO E DISCUSSÕES - PERFIL METÁLICO ...................................93

4.4.5 RESULTADO E DISCUSSÕES - PERFIL MISTO _.....................................96

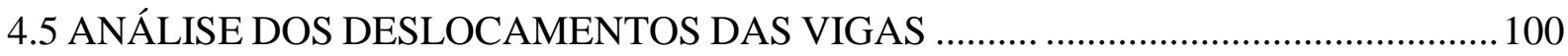

4.6 ANÁLISE DOS ENSAIOS EM TEMPERATURAS ELEVADAS COM O MESMO

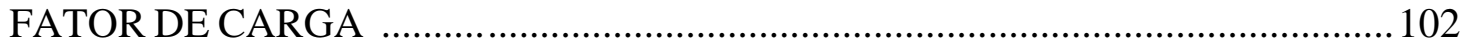

4.7 COMPARAÇÃO COM A PESQUISA DE PILOTO …............................................... 103

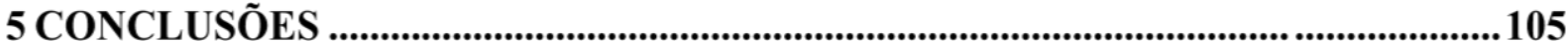

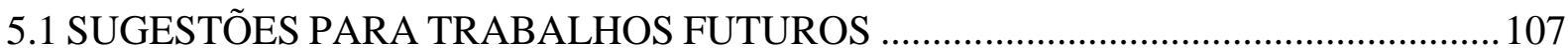

REFERÊNCIAS BIBLIOGRÁFICAS .............................................................109

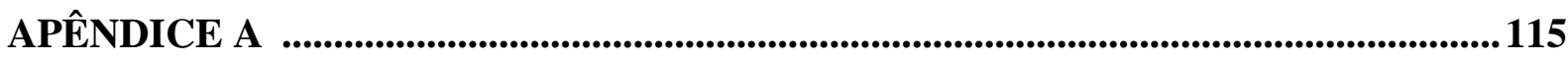

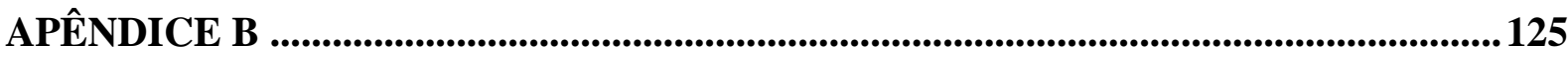





\section{Capítulo 1}

\section{INTRODUÇÃO}

O incêndio sempre constituiu um risco considerável à propriedade e à segurança humana. Quando ocorre de forma descontrolada, pode ocasionar consequências devastadoras. Conforme mencionado em Silva (2001), no passado se acreditava que o incêndio era obra do acaso e a vítima uma infortunada. Hoje, sabese que o incêndio é uma ação que pode ser evitada, e as vítimas, quer por morte ou por perda do patrimônio, surgem por consequência de ignorância ou ato criminoso.

Em Wang (2002) se afirma que as medidas de combate a incêndios em edificações tem seguido procedimentos que evoluíram durante vários anos em resposta aos desastres ocorridos anteriormente. Com relação às exigências de resistência ao fogo de elementos estruturais de aço e mistos de aço e concreto em situação de incêndio, a maioria dos regulamentos e códigos normativos do mundo todo ainda tem por base ensaios de elementos isolados em fornos.

Atualmente é reconhecido o fato de as prescrições normativas conduzirem, em geral, a projetos antieconômicos e inflexíveis. Por esta razão, no contexto internacional, a regulamentação de segurança contra incêndio em edificações tem evoluído no sentido de se libertar progressivamente das exigências de caráter prescritivo, passando a basear-se mais no desempenho dos elementos estruturais expostos a situações de incêndios reais. 
Em Vila Real (2003), são citados aspectos que permitem identificar a diferença entre a abordagem prescritiva e aquela baseada no desempenho, com relação ao comportamento de uma estrutura de interesse em situação de incêndio. Na última referência, cita-se que em uma abordagem prescritiva limita-se, por exemplo, a temperatura do aço um valor denominado "temperatura crítica", isto é, a temperatura de colapso do elemento quando exposto às curvas "temperatura-tempo" normalizadas.

Esta abordagem tem por base o pressuposto de que, para temperaturas superiores àquela denominada "temperatura crítica", uma dada estrutura metálica, por exemplo, não é segura. Com este procedimento, a avaliação da temperatura do aço é objetivo último e, neste caso, de principal interesse. Não são levadas em conta circunstâncias particulares às quais a estrutura é sujeita ao incêndio, tais como: o tipo de incêndio, as consequências da exposição ao fogo, condições de carregamento ou mesmo a interação entre os vários elementos estruturais.

Por outro lado, em abordagens baseadas no desempenho, todos os fatores são ponderados e a temperatura do aço é apenas uma das muitas variáveis envolvidas. Nesta abordagem, apesar de consistir de um procedimento mais custoso, é possível obter respostas da estrutura, quando submetida a elevadas temperaturas, bem mais representativas quando comparada às reais situações de incêndio.

Os avanços ocorridos no contexto mundial com relação ao entendimento do desempenho de estruturas em altas temperaturas e as maiores exigências quanto à segurança em situação de incêndio por parte do Corpo de Bombeiros nos grandes centros têm estimulado, no Brasil, estudos relacionados ao tema "segurança contra incêndio" com destaque ao desempenho de estruturas em situações de incêndio.

\subsection{Objetivos}

O objetivo geral dessa pesquisa é a caracterização do comportamento estrutural de vigas de aço e mistas de aço e concreto parcialmente revestidas em situação de incêndio. 
Como forma de atingir o objetivo principal apresentado, foram realizados ensaios experimentais em situação de incêndio em vigas metálicas e vigas mistas com concreto entre as mesas do perfil metálico. Uma análise térmica bidimensional foi feita afim de consolidar os resultados obtidos experimentalmente. O estudo experimental também tem como objetivo o ganho de experiência dos pesquisadores envolvidos para a futura aplicação em análises experimentais no forno horizontal localizado no Departamento de Engenharia de Estruturas da EESC/USP.

\subsection{Justificativa}

Com o crescente uso dos elementos mistos de aço e concreto, os benefícios estruturais começaram a ser notados. Tal associação resulta na melhor utilização de ambos os materiais, não somente no que se refere à capacidade resistente, mas também no ponto de vista construtivo, funcional e estético, minimizando os inconvenientes intrínsecos de cada material (Paes, 2003).

Além disso, o comportamento das estruturas em situação de incêndio tem sido assunto de crescente interesse nos meios técnico e científico devido aos incidentes ocorridos ao longo dos anos. O aumento de temperatura nas estruturas é um efeito bastante nocivo, pois esta penaliza a rigidez e a resistência dos materiais, podendo levar, em questão de minutos, uma estrutura ao colapso.

Tendo em vista o interesse no estudo das estruturas em situação de incêndio, atenta-se para o fato de que muitos dos trabalhos encontrados na literatura apresentam, em sua grande maioria, estudos essencialmente numéricos ou ensaios de elementos isolados submetidos ao incêndio-padrão. Em Kodur et al. (2012), é levantada a necessidade de se abordar, em ensaios futuros, situações que representem mais fielmente as reais condições que o elemento estrutural está submetido. No caso dos elementos estruturais de interesse no trabalho, essas condições podem se referir a situações mais reais de incêndio, que poderão ser analisadas com um modelo numérico adequadamente validado. 
A necessidade de mais dados experimentais para a validação de modelos numéricos também é ressaltada em Kodur et al. (2012), podendo-se também citar o caso dos ensaios em escala real feitos em Cardington, em 2000, cujos resultados são utilizados até hoje, mostrando o impacto de ensaios bem desenvolvidos na área de estruturas em situação de incêndio.

O trabalho não será importante apenas no que diz respeito à compreensão do comportamento do elemento estrutural em temperatura elevadas, mas também na questão do método aplicado de ensaios de elementos mistos de aço e concreto em temperatura elevada, aumentando a experiência dos pesquisadores envolvidos na utilização do forno disponível no Departamento de Engenharia de Estruturas da EESC/USP em São Carlos.

\subsection{Metodologia}

A fim de atingir os objetivos determinados, o trabalho abordou análises experimentais e numéricas de vigas de aço e mistas de aço e concreto parcialmente revestidas (concreto entre as mesas do perfil) em situação de incêndio. $O$ trabalho foi desenvolvido por análise experimental, descrita no que segue.

\subsubsection{Análise experimental}

As análises experimentais foram realizadas no Laboratório de Engenharia de Estruturas da EESC/USP, utilizando um forno horizontal (Figura 1.1) de grandes dimensões para o ensaio de elementos estruturais como vigas e lajes, em situação de incêndio, o qual foi adquirido por meio de projeto temático FAPESP 2006/06742-5 "Segurança das Estruturas em Situação de Incêndio", concluído em julho de 2013.

O forno possui dimensões internas de $3 \mathrm{~m} \times 4 \mathrm{~m} \times 1,5 \mathrm{~m}$, com funcionamento a gás. A temperatura máxima por ele atingida resulta em torno dos $1260^{\circ} \mathrm{C}$. O aquecimento dos gases obedece quaisquer curvas, inclusive curvas padronizadas como aquela proposta pela ISO 834 (Figura 1.2) e denominada curva de incêndiopadrão. Possui como característica principal apenas um ramo ascendente, admitindo 
assim que a temperatura dos gases sempre cresça com o tempo, independentemente das características do ambiente e da quantidade de material combustível presente.

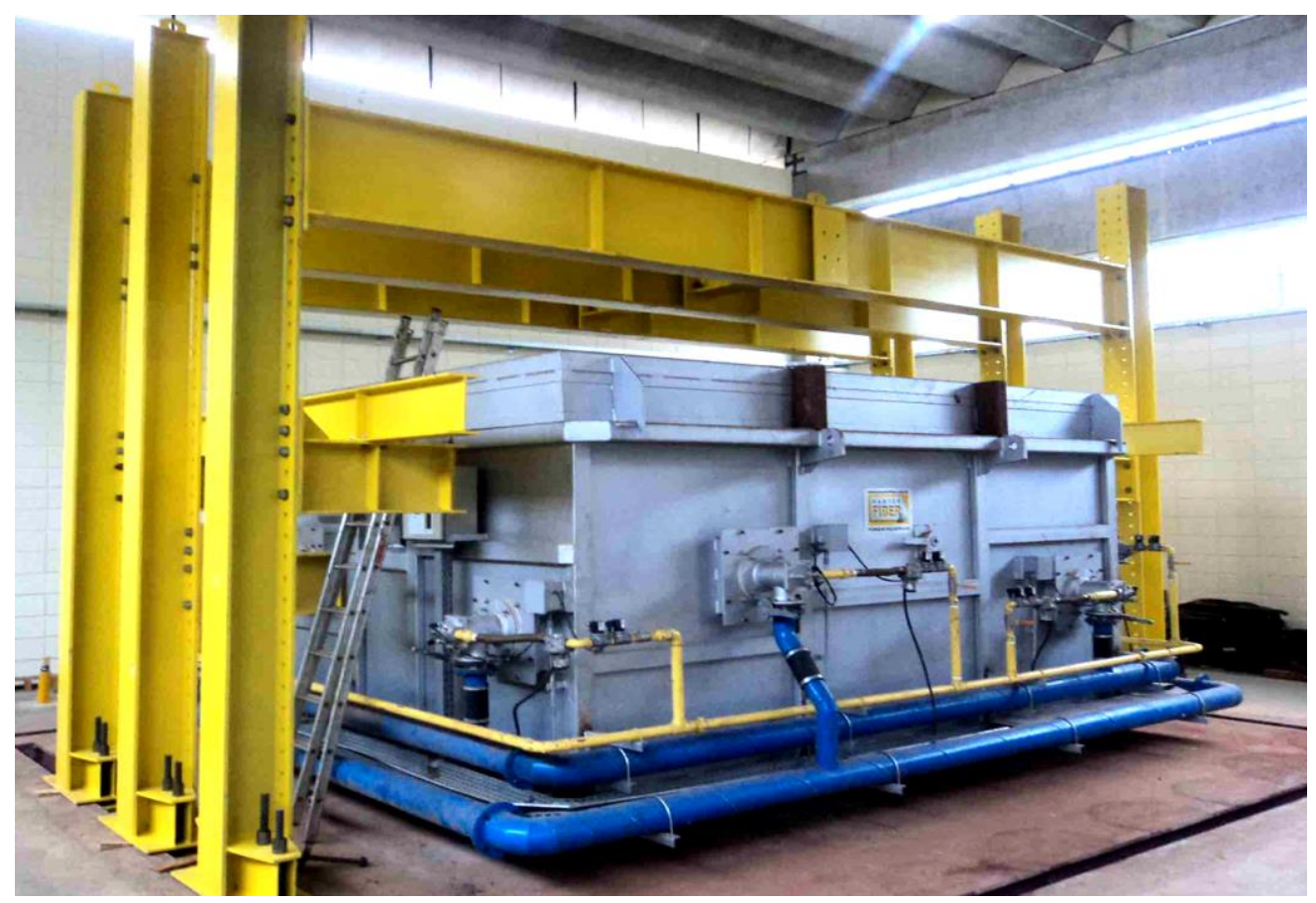

Figura 1.1 - Forno horizontal alimentado a gás da EESC/USP

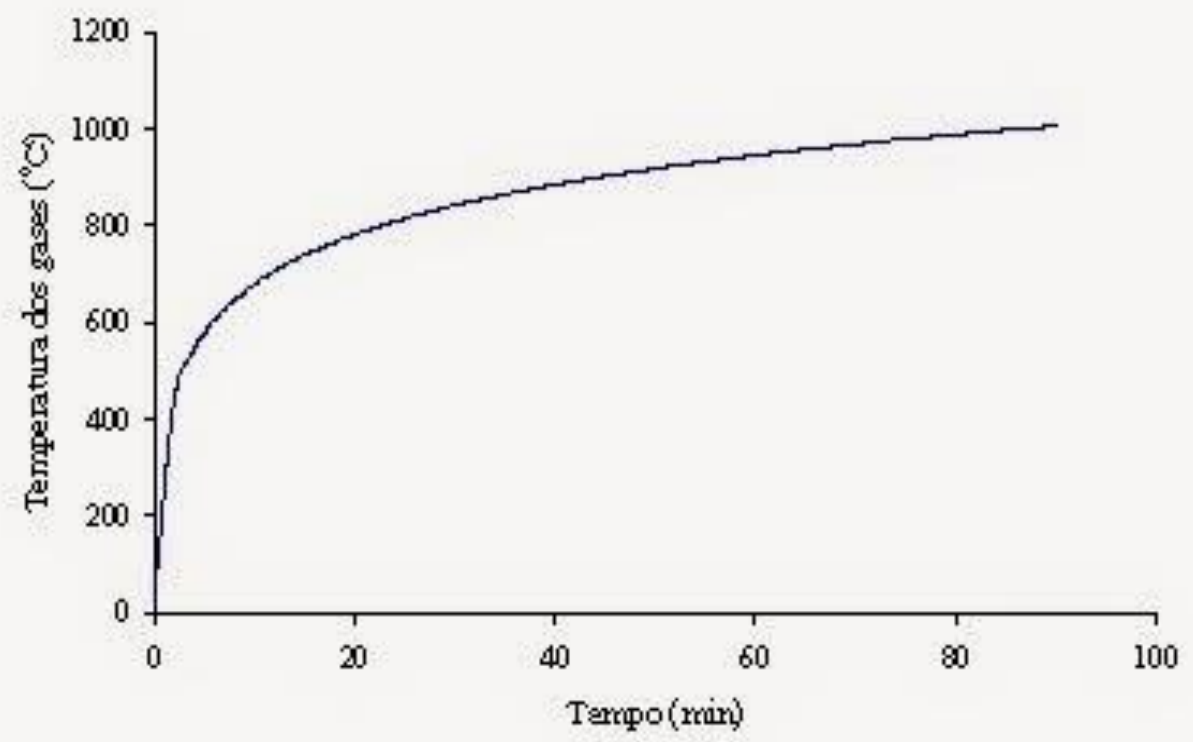

Figura 1.2 - Curva de Incêndio-Padrão, conforme ISO 834:1999 
O programa experimental consistiu de ensaios de 6 vigas, considerando 2 vigas de aço e 4 vigas mistas de aço e concreto, todas com $6000 \mathrm{~mm}$ de comprimento e $5100 \mathrm{~mm}$ de vão, constituídas pelo perfil laminado W250 x 32,7. As vigas mistas serão preenchidas com concreto classe $\mathrm{C} 60$ entre as suas mesas.

Primeiramente foram realizados dois ensaios de vigas submetidas à flexão à temperatura ambiente, para a determinação da força última, de colapso, do elemento estrutural e também ensaios de caracterização do aço e do concreto, enquanto materiais. A segunda etapa da análise experimental, já em situação de incêndio, consistirá em quatro ensaio de vigas simplesmente apoiadas submetidas a três níveis diferentes de forças, no caso, fatores de carga $30 \%$ e $45 \%$ da força última à temperatura ambiente, porém expostas ao incêndio-padrão.

Maiores detalhes sobre as análises experimentais previstas no presente trabalho serão apresentados nos capítulos seguintes do presente texto.

\subsection{Organização do trabalho}

No Capítulo 1 uma breve abordagem do tema foi realizada, apresentando os objetivos e justificativas para a realização do trabalho, assim como a metodologia adotada para o desenvolvimento do projeto.

O Capítulo 2 apresenta o estado de arte com base em estudos realizados com vigas mistas de aço e concreto em altas temperaturas.

No Capítulo 3 o programa experimental realizado foi apresentado e discutido. Bem como, é detalhada a metodologia adotada e os resultados obtidos.

No Capítulo 4 foram feitas várias análises comparativas com dados dos resultados encontrados experimentalmente. Cálculos teóricos foram feitos, assim como uma análise térmica bidimensional no ABAQUS.

O Capítulo 5 foi dedicado às conclusões e discussões finais obtidas por meio dos capítulos anteriores. São apresentados também sugestões para futuros trabalhos na área. 
Este trabalho também contém o Apêndice $\mathbf{A}$ que traz os conceitos básicos de incêndio, e o Apêndice $\mathbf{B}$ onde é apresentado o registro fotográfico mais completo dos ensaios e etapas realizadas. 


\section{Capítulo 2}

\section{VIGAS MISTAS DE AÇO E CONCRETO}

\subsection{Introdução}

Segundo Queiroz (2010), denomina-se sistema misto de aço e concreto aquele no qual um elemento de aço trabalha estruturalmente em conjunto com um elemento de concreto (geralmente armado), formando pilares, vigas, lajes ou ligações mistas. Nos primeiros casos observados de elementos metálicos associados com o concreto, o comportamento misto não era considerado, sendo o concreto utilizado apenas como forma de proteção à corrosão ou ao fogo.

Com o crescente uso dos elementos mistos de aço e concreto, os benefícios estruturais começaram a ser notados, percebendo que tal associação resultava na melhor utilização de ambos os materiais, não somente no que se refere à capacidade resistente, mas também no ponto de vista construtivo, funcional e estético, minimizando os inconvenientes intrínsecos de cada material (Paes, 2003).

Segundo Malite (1993), os primeiros estudos sobre vigas mistas de aço e concreto ocorreram por volta de 1914, na Inglaterra, onde foram realizados diversos ensaios em sistemas de pisos mistos de aço e concreto. Em 1930 já era conhecido o método de dimensionamento de estruturas mistas, sendo que nas décadas de 20 e 30 vários edifícios foram construídos nesse sistema, entre eles, os mundialmente 
conhecidos EMPIRE STATE BUILDING (Figura 2.1-a) e CHRYSLER BUILDING (Figura 2.1-b), ambos localizados na cidade de Nova lorque. As normas da American Association of State Highway (AASHO), em 1944, e a da American Institute of Steel Construction, em 1952, foram as primeiras a apresentar métodos de dimensionamento para elementos mistos de aço e concreto (De Nardin, 1999).
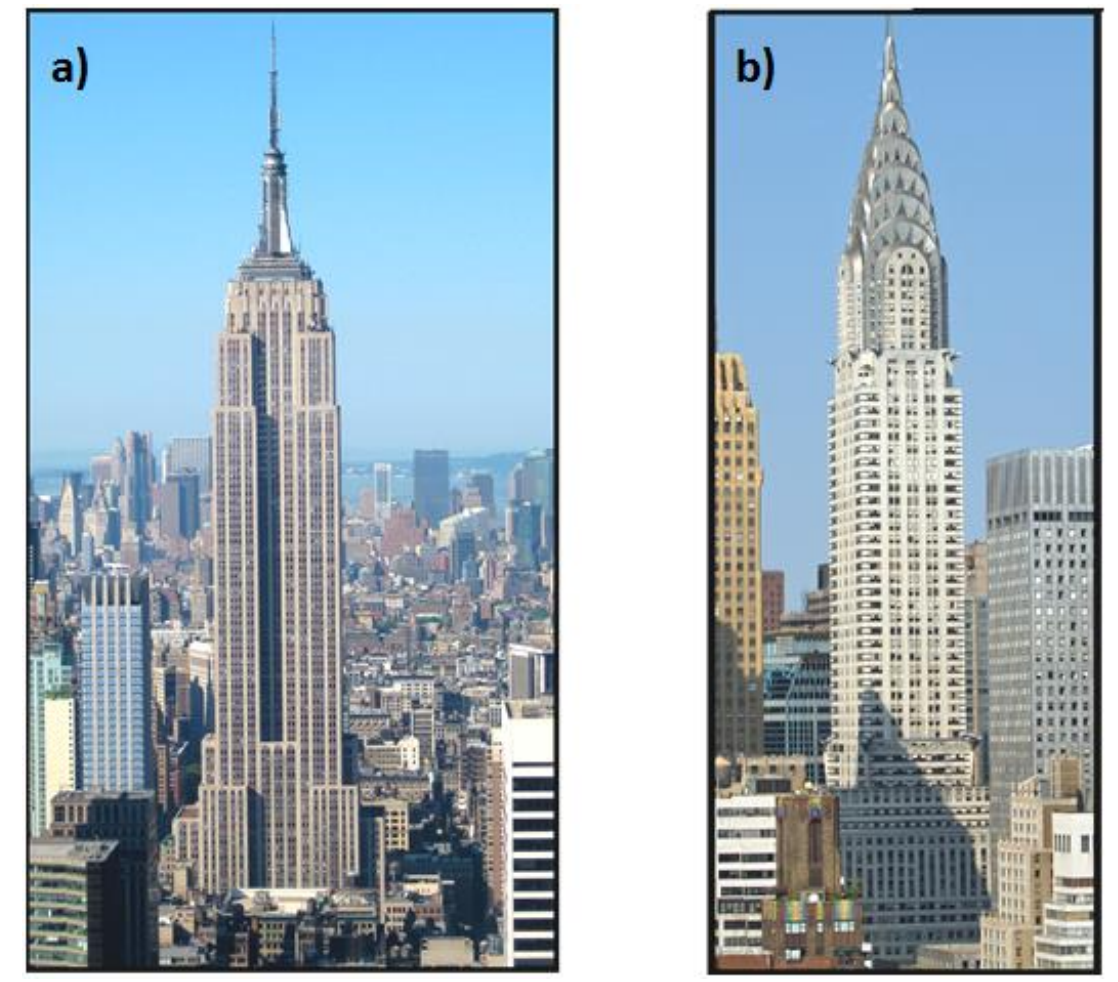

Figura 2.1 - (a) Empire State Building e (b) Chrysler Building

Já em contexto de cenário nacional, os primeiros edifícios em estrutura mista de aço e concreto foram construídos décadas depois, mais precisamente nos anos 50. Em Figueiredo (1998) são listadas obras desse período, citando como exemplos o EDIFÍCIO GARAGEM AMÉRICA, em 1957, com 16 pavimentos e mais de 15.000 $\mathrm{m}^{2}$ de área, e o Edifício sede do IPERJ, em 1965, com 24 pavimentos. Porém, como citado em Malite (1993), houve uma estagnação da construção metálica na década de 70 e início da década de 80, sendo que os edifícios e pontes ficaram restritos aos sistemas de concreto armado e protendido, mesmo nos casos em que a utilização do concreto não fosse a mais economicamente vantajosa.

Segundo Queiroz (2010), a utilização de sistemas mistos de aço e concreto amplia, consideravelmente, a gama de soluções em concreto armado e em aço, 
representando ganhos significativos na capacidade resistente de pilares e vigas, possibilitando também o uso de novas disposições construtivas, perfis e dimensões da obra. As vantagens dos sistemas construtivos mistos em relação aos sistemas convencionais metálicos ou de concreto armado se dão tanto no referente aos aspectos arquitetônicos quanto econômicos.

Dessa forma, os perfis metálicos em associação com a laje de concreto apresentam ganho de rigidez, podendo suportar vãos ainda maiores com perfis mais leves, diminuindo o consumo total de aço e, consequentemente, o custo total da obra. O sistema misto também apresenta vantagens quando analisados em relação aos processos de montagem. Nos casos em que se utiliza o sistema de laje mista com forma de aço incorporada, é dispensado o uso de formas de madeira, e ocorre considerável redução nos escoramentos, além de ser um método mais rápido de ser executado, proporcionando ganho de tempo na obra e antecipando o retorno do capital investido.

A primeira norma brasileira a contemplar o tema foi a ABNT NBR 8800:1986 "Projeto e Execução de Estruturas de Aço de Edifícios", apresentando método de dimensionamento para vigas mistas. Hoje, sua versão mais recente data de $2008 \mathrm{e}$ apresenta o dimensionamento para lajes, pilares, vigas e ligações mistas. A norma brasileira para perfis formados a frio também contempla o assunto de estruturas mistas, mas remete à anterior para a realização do dimensionamento, salvo algumas condições lá citadas. Em contexto internacional, o EUROCODE 4 contempla exclusivamente $o$ assunto de estruturas mistas de aço e concreto.

No que diz respeito à normatização para o dimensionamento em situação de incêndio, a norma brasileira ABNT NBR 14323:2013 possui um anexo para o cálculo de vigas mistas, contemplando apenas o caso do sistema misto convencional, com laje sobre a mesa superior do perfil. Já o EUROCODE 4 Part 1.2, possui o método dimensionamento para vigas mistas convencionais e parcialmente revestidas. 


\subsection{Efeito do concreto entre as mesas no comportamento estrutural de vigas fletidas à temperatura ambiente}

A seguir serão apresentadas as principais pesquisas e conclusões obtidas acerca do comportamento estrutural das vigas mistas parcialmente revestidas com concreto situado apenas entre o perfil metálico, sem a consideração da laje de concreto.

$\mathrm{Na}$ versão de 1992 do EUROCODE 4, não era possível determinar a capacidade resistente e deslocamentos de vigas mistas parcialmente revestidas levando em consideração o concreto armado entre as mesas do perfil metálico. Partindo dessa deficiência no código normativo europeu, foi desenvolvido o trabalho apresentado em Kindmann et al. (1993), que apresentou um método simplificado de cálculo a partir de uma série de modelos experimentais. Foram realizados 12 ensaios com diferentes vigas e seções transversais, e em apenas dois desses ensaios foi considerada a laje de concreto integrada ao perfil metálico. Entretanto, os resultados desses testes levaram a conclusões similares às demais. As seções analisadas são mostradas na Figura 2.2.
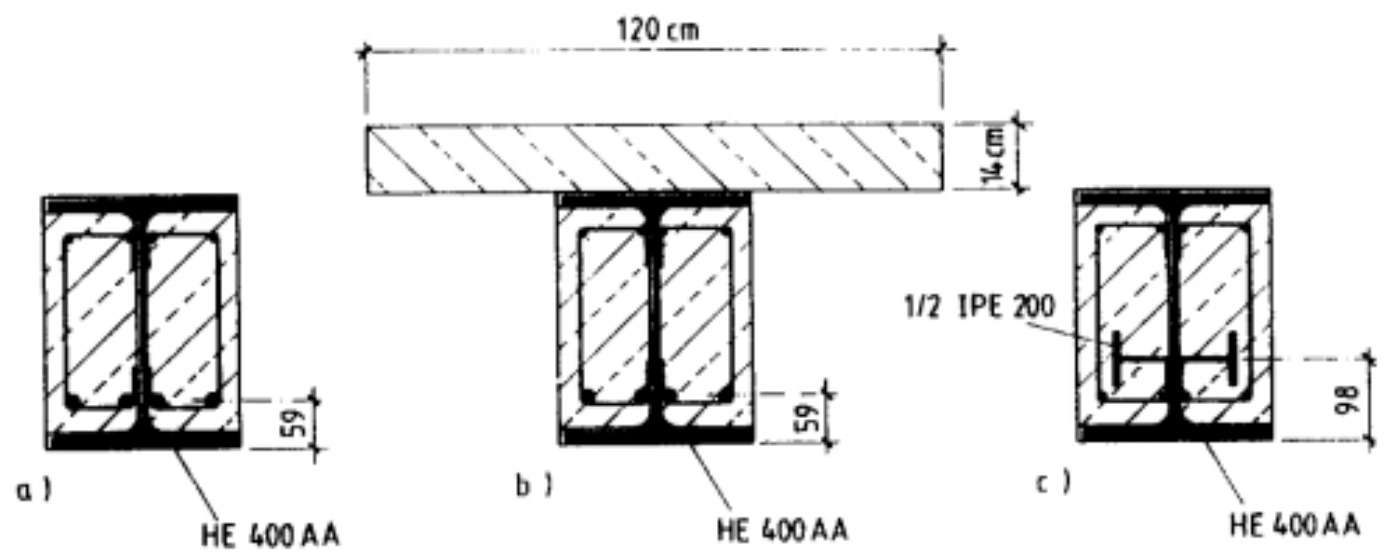

Figura 2.2 - Seções transversais ensaiadas em Kindmann et al. (1993)

Além dos casos com e sem conectores, Figura 2.2-c e Figura 2.2-a, em alguns modelos os perfis metálicos tiveram uma camada de óleo entre o aço e o concreto de revestimento, com a finalidade de anular qualquer adesão do concreto na interface. Já nos casos com conectores, Kindmann et al. (1993) justifica o seu uso apenas por 
razões construtivas, pois os conectores impedem que o concreto se desprenda do perfil metálico quando a viga é virada durante a concretagem. Também foi verificada a influência da armadura na resposta estrutural dessas vigas.

Dentre as principais conclusões obtidas na última referência, além do modelo de cálculo desenvolvido, pode-se observar que a influência do concreto de revestimento e a armadura lá inserida contribuíam significativamente para a capacidade resistente do elemento à flexão, como se era de esperar.

Também se verificou que em todas as vigas foi desenvolvido o comportamento misto, mesmo quando da inexistência de conectores de cisalhamento ou barras soldadas à alma do perfil. Por fim, para vãos curtos, a consideração do concreto entre as mesas em conjunto com a armadura, resultou em um acréscimo de $22 \%$ na resistência ao cisalhamento, dominante nesse caso. Nas vigas com vãos intermediários, o momento fletor é quem determina o colapso da viga, cujo carregamento máximo suportado obtido resultou $29 \%$ maior quando comparado com o sistema misto convencional.

Em Nakamura \& Narita (2003) também foi verificado o aumento na capacidade resistente quando utilizadas as vigas mistas parcialmente revestidas em pontes, como mostrado na Figura 2.3.

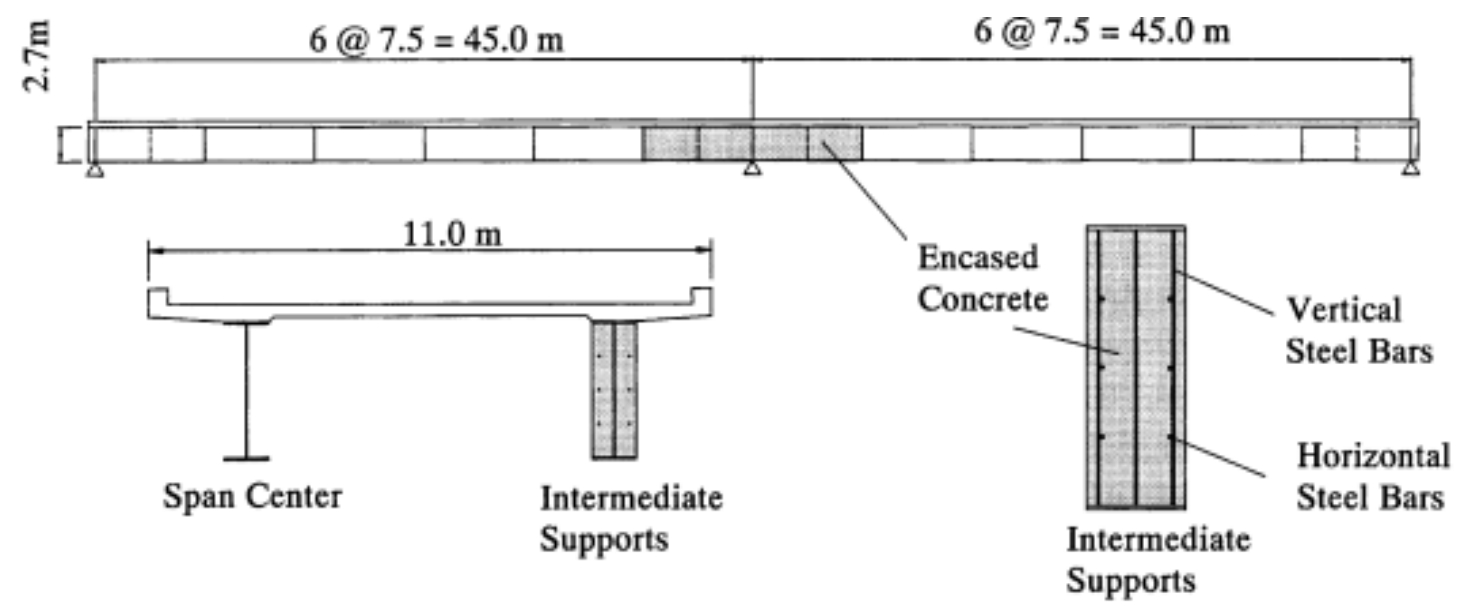

Figura 2.3 - Esquema estudado em Nakamura \& Narita (2003) 
Além do concreto entre as mesas, também foram utilizadas barras de aço soldadas ao perfil metálico, resultando em vigas com resistências ao cisalhamento e à flexão 2,98 e 2,08 vezes maior que as obtidas utilizando o sistema misto convencional, respectivamente. Quando as barras não eram soldadas ao perfil metálico o aumento das resistências ao cisalhamento e à flexão ainda era notado, mas com menor intensidade, cujos valores resultaram 1,75 e 1,89 vezes maiores que os de referência, respectivamente.

Para que haja o aumento na capacidade resistente da seção mista, deve-se garantir que o comportamento misto seja eficiente nas vigas mistas parcialmente revestidas. No trabalho apresentado em Weng et al. (2002), foram realizados ensaios em vigas metálicas totalmente revestidas por concreto, visando analisar a ruptura por cisalhamento na interface.

Foram realizados nove (9) ensaios, em que foram observados dois tipos diferentes de ruptura: por flexão e por cisalhamento. A ruptura por cisalhamento era identificada por fissuras horizontais e a queda brusca do carregamento ao atingir 0 ponto crítico, resultando em um comportamento frágil que deve ser evitado. Para isso, verificou-se que a relação entre a largura da mesa do perfil metálico e a largura total da seção deve ser menor que 0,67 . Caso contrário, era observada a ruptura por flexão.

Ainda no que diz respeito ao estudo da interação entre o aço e o concreto, em Nardin\& El Debs (2009) foi analisado o comportamento estrutural de vigas parcialmente revestidas utilizando conectores de cisalhamento em diferentes posições do perfil metálico: soldado verticalmente à mesa inferior do perfil e horizontalmente à alma do perfil. As vigas analisadas só apresentavam concreto entre as mesas do perfil metálico, como pode ser visto na Figura 2.4.

Os resultados experimentais mostraram que a melhor posição para utilizar os conectores de cisalhamento é vertical soldado à mesa inferior do perfil. No entanto, a capacidade da carga não teve aumento significativo devido a essa configuração. Pode-se concluir que os elementos com conectores de cisalhamento podem ser considerados dúcteis e com comportamento elastoplástico, enquanto que os sem conectores apresentaram um comportamento inferior aos outros testes, com capacidade de carga mais baixa, como apresentado na Figura 2.5. Adicionalmente, 
um método analítico para determinar a capacidade à flexão das vigas revestidas foi proposto, apresentando boa conformidade com os resultados experimentais.

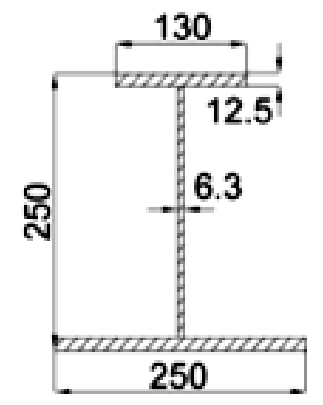

(a) PEB.

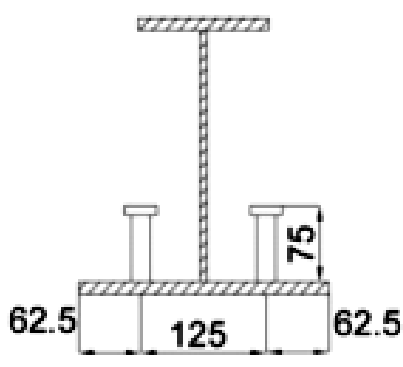

(b) PEB-B.
62.5

(c) PEB-W.

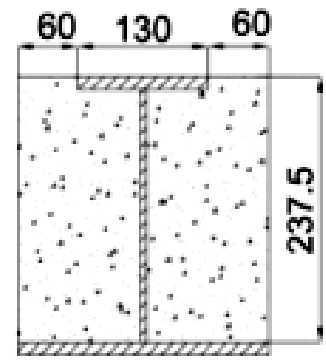

(d) Cross-section.

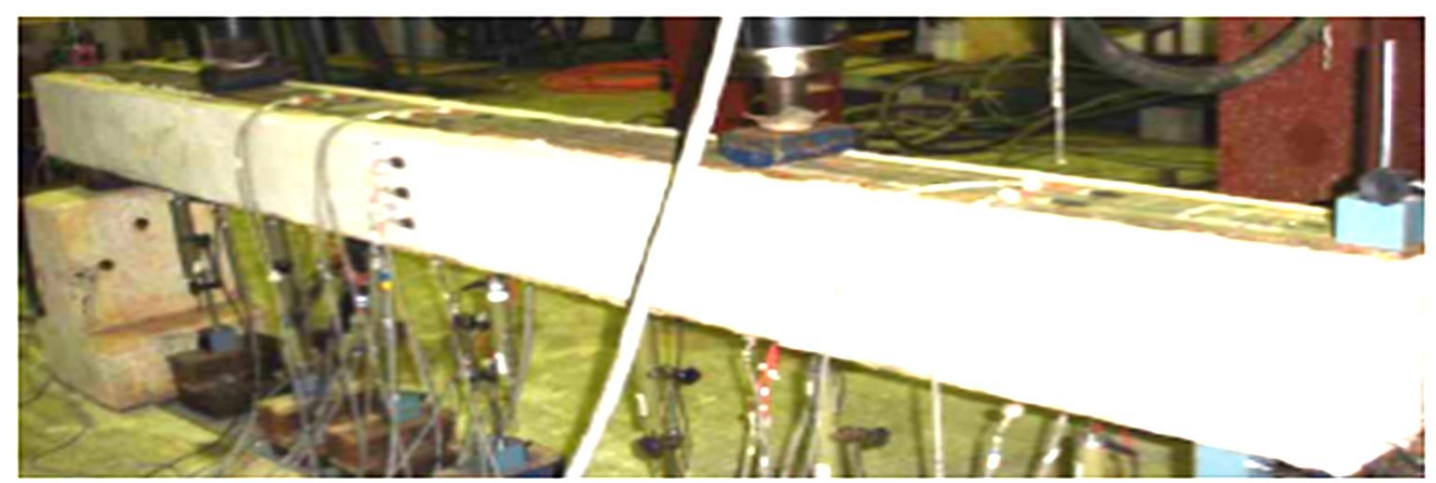

Figura 2.4 - Vigas parcialmente revestidas ensaiadas em De Nardin \& EI Debs (2009).
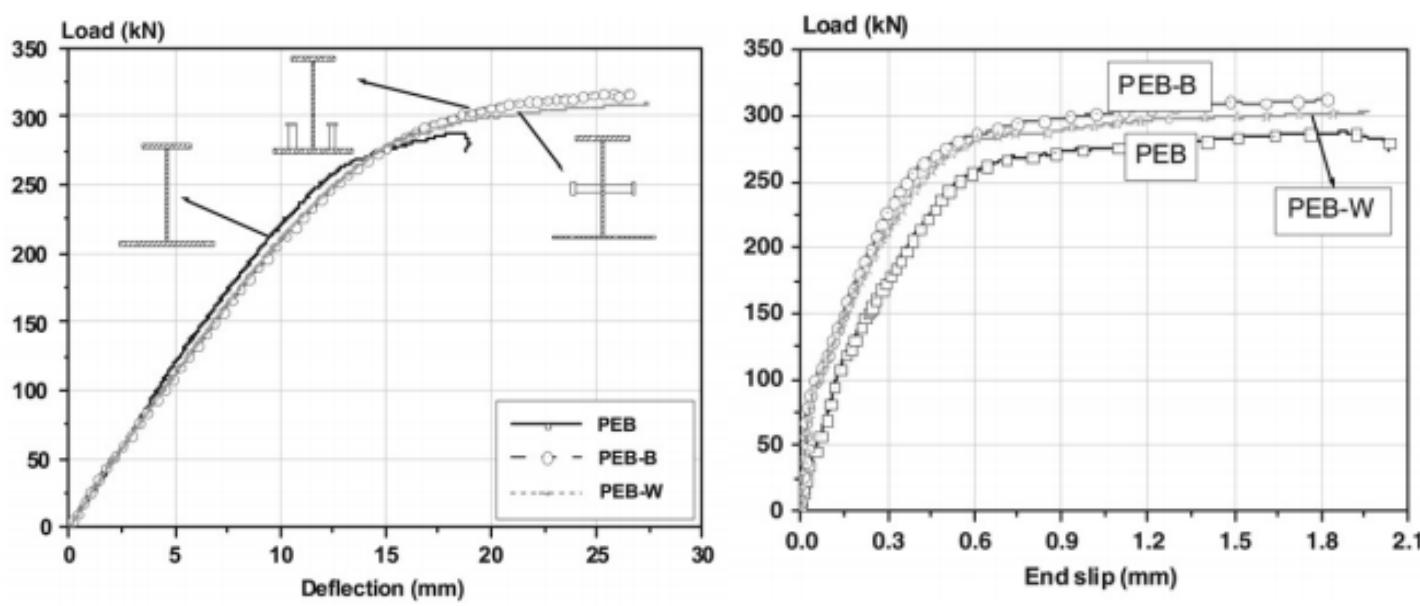

Figura 2.5 - Comportamento estrutural das vigas ensaiadas em De Nardin\& El Debs (2009)

Em Cavalcanti (2010) foram investigadas vigas parcialmente revestidas, considerando os mesmos modelos utilizados em De Nardin\& El Debs (2009), porém analisando a influência da armadura, quando colocada entre as mesas do perfil metálico, na capacidade resistente do elemento estrutural. No trabalho foi utilizado o 
código computacional TNO DIANA com uma abordagem de modelagem 2D simplificada.

Por fim, destaca-se o trabalho experimental apresentado em De Nardin \& El Debs (2012), onde foram desenvolvidos ensaios em ligações viga-pilar. A ligação consistia do piso misto de baixa altura conectado, por meio de uma chapa metálica, a um pilar misto preenchido. Também foram realizados ensaios utilizando vigas metálicas sem o revestimento de concreto, a fim de avaliar a influência da laje no comportamento da ligação. No final do trabalho foi verificado que a consideração do elemento misto aumentou a capacidade resistente da ligação.

\subsection{Vigas Mistas Parcialmente Revestidas em Situação de Incêndio}

Neste item são apresentadas algumas pesquisas desenvolvidas contemplando as vigas mistas parcialmente revestidas em situação de incêndio, porém ressaltando que cada centro de pesquisa estava focado na análise das seções que mais se adequavam ao contexto do seu país.

No caso de Newman (1995) se tem os primeiros estudos que contemplaram a análise em temperatura elevada, desenvolvidos em contextos numérico e experimental com o sistema slim floor, formado a partir da união soldada de um perfil do tipo "Universal Column" a uma chapa metálica. Já em Mäkeläinen \& Ma (2000), Ma \& Mäkeläinen (2000) e Bailey (1999), foram estudadas as vigas com abas assimétricas e em Schaumann \& Hothan (2002), as chamadas Hat Beams.

Os estudos considerando diferentes seções transversais é consequência da grande variabilidade de soluções construtivas no sistema slim floor. Mas, independente do sistema adotado, a grande maioria das pesquisas contemplou a análise numérica dos elementos. Apesar de desejável a realização de ensaios experimentais em fornos para determinar o comportamento estrutural dos elementos estudados frente ao incêndio, bem como usar esses dados para validação de modelos numéricos, o ensaio de elementos em escala natural é mais caro e trabalhoso que um ensaio à temperatura ambiente. Além disso, poucos laboratórios possuem os 
equipamentos necessários para a realização de análises experimentais em temperaturas elevadas, limitando ainda mais a sua viabilidade.

Tendo em vista as afirmações anteriores, muitos trabalhos apresentaram a análise numérica das vigas slim floor. Inicialmente, como apresentado em Newman (1995) e Mäkeläinen \& Ma (2000), foi analisada apenas a seção transversal do elemento, com as temperaturas calculadas a partir do método das diferenças finitas, considerando as leis de troca de calor de Fourier e parâmetros térmicos de material e do meio. Além dos parâmetros térmicos de material, como calor específico e condutividade, também eram necessários os parâmetros relativos à troca de calor com o meio, sendo eles a emissividade da superfície e o coeficiente de troca de calor por convecção.

Esses parâmetros já eram adotados de forma semelhante ao que é apresentado hoje no EUROCODE 4 Part 1.2 (2005). A principal diferença observada diz respeito às emissividades, pois nos casos apresentados, onde as lajes eram mistas com fôrma de aço incorporada, a emissividade dessas superfícies era adotada igual a 0,4, enquanto que a do perfil metálico era 0,6. Vale ressaltar que o EUROCODE 4 não faz distinção da emissividade de acordo com o tipo de material, consideração essa que leva a resultados diferentes dos reais para esses casos.

Outras conclusões a respeito dos parâmetros térmicos, utilizados nas análises numéricas, foram obtidas via análise experimental dos elementos, como, por exemplo, Newman (1995), em que, visando a análise mais detalhada de vigas do tipo slim floor, se realizou também ensaios com seis seções transversais diferentes todas com as chapas soldadas às vigas com espessura de $15 \mathrm{~mm}, 200 \mathrm{~mm}$ mais largas que as mesas inferiores dos perfis metálicos e com soldas de $8 \mathrm{~mm}$, variando apenas a geometria da fôrma e o tipo de preenchimento da laje.

Foi possível observar, a partir dos resultados obtidos, que sempre houve uma diferença de temperatura considerável entre a chapa de aço e a mesa inferior do perfil, sendo esse fato associado à resistência térmica nessa interface. No modelo numérico foi implementada a resistência térmica da interface por meio do coeficiente $\mathrm{Ki}$, sendo utilizados os valores de $\mathrm{Ki}=200 \mathrm{~W} / \mathrm{m}^{2 \circ} \mathrm{C}$ nas zonas de contato entre aço e aço (Perfil e chapa de aço) e $\mathrm{Ki}=50 \mathrm{~W} / \mathrm{m}^{2 \circ} \mathrm{C}$ nas interfaces entre o aço e o concreto. Essa 
consideração é levada em conta até hoje na modelagem numérica por esse e outros autores (Mäkeläinen \& Ma, 2000; Schaumann \& Hothan, 2002; Ellobody, 2012).

Ainda nos trabalhos apresentados em Newman (1995) e Mäkeläinen \& Ma (2000), a partir do campo térmico da seção transversal, a capacidade resistente das vigas era calculada por meio do método dos momentos plásticos. No caso do cálculo realizado em Newman (1995), foi desconsiderado todo concreto abaixo da mesa superior do perfil, pois a linha neutra plástica (LNP) estava sempre acima ou muito próxima desta região e, com isso, o concreto localizado abaixo da LNP resultava tracionado. Também foi considerado que todo o concreto acima da mesa superior mantém sua resistência total, pois assume que está com temperatura inferior a $100^{\circ} \mathrm{C}$. O mesmo foi considerado para a região superior da alma, sendo encontradas temperaturas inferiores a $350^{\circ} \mathrm{C}$.

Por meio dessa análise, Newman (1995) pode observar que, quando comparado a um sistema misto convencional, no qual o colapso ocorria quando a mesa do perfil estava com temperatura próxima de $600^{\circ} \mathrm{C}$, nas vigas do sistema slim floor o mesmo ocorria, na maioria dos casos, com temperaturas superiores aos $700^{\circ} \mathrm{C}$ e com maior tempo de exposição ao fogo. Comparando os resultados numéricos e experimentais realizados também pelo autor, notou-se resultados sempre próximos, com uma margem de diferença da ordem de $10 \%$, concluindo que o método de cálculo a partir do momento resistente plástico pode ser utilizado, mas aconselha a utilização de um fator de correção de 1,1 .

Em Mäkeläinen \& Ma (2000), o cálculo dos momentos plásticos das seções com vigas assimétricas (Figura 2.6) foi determinado de forma mais completa, pois os campos térmicos eram calculados para todo o intervalo de exposição ao fogo, e consequentemente, a posição da LNP e o Momento plástico resistente.

Dessa forma, era possível observar a variação desses parâmetros com o tempo de exposição ao fogo. A respeito do cálculo dos momentos plásticos, as resistências ao escoamento do aço e à compressão do concreto eram calculadas de acordo com a temperatura obtida na análise térmica e os fatores de redução apresentados no EUROCODE 4. Só era desconsiderado o concreto tracionado abaixo ou acima da 
LNP, dependendo do sinal do momento considerado. Esse método resulta mais completo que o apresentado em Newman (1995), sem realizar tantas simplificações.

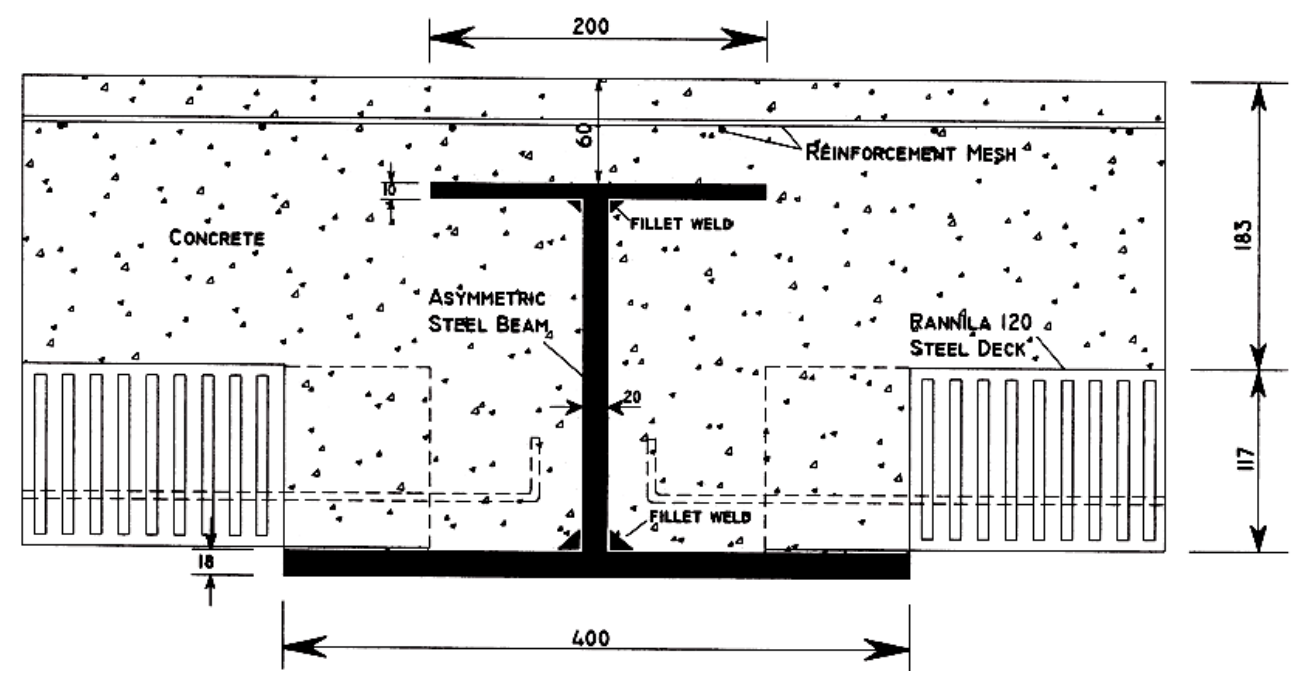

Figura 2.6 - Seção transversal de viga assimétrica soldada estudada, Mäkeläinen \& Ma (2000).

A validação do modelo foi realizada a partir dos resultados de dois ensaios de vigas, desenvolvidos pelo $\mathrm{SCl}$ com vigas de abas assimétricas, apresentados em Lawsonet al. (1997), e também com relação a alguns pilares e outros tipos de vigas mistas. Nos resultados de Mäkeläinen \& Ma (2000) se verifica uma grande variação da temperatura, da ordem de $200^{\circ} \mathrm{C}$, entre a extremidade e o meio da mesa inferior do perfil metálico, assim como na alma, apresentando gradiente térmico bastante acentuado. Isso ocorre devido ao revestimento oferecido pelo concreto, sendo que a maior parte da alma apresenta temperaturas inferiores a $400^{\circ} \mathrm{C}$ e, dessa forma, conserva boa parte de sua resistência.

Por fim, no topo do piso de concreto as temperaturas são inferiores a $50^{\circ} \mathrm{C}$ garantindo o critério de isolamento no piso superior. Essas temperaturas foram calculadas para o tempo de 60 minutos de exposição à curva de incêndio-padrão de acordo com a ISO 834. O mesmo padrão dos campos térmicos foi observado em Newman (1995).

A partir do método dos momentos plásticos, Mäkeläinen \& Ma (2000) realizam a análise de cada região do perfil na composição da capacidade resistente da seção, observando que nas regiões de momento positivo, após 60 minutos de exposição ao incêndio-padrão ISO 824, a contribuição da mesa inferior do perfil diminui de 59\% para 
$26 \%$, enquanto que a contribuição da região da alma abaixo da LNP aumenta de $14 \%$ para $55 \%$. A mesa superior possui pequena representatividade na composição do momento plástico, uma vez que a LNP se encontra bastante próxima à temperatura ambiente e em temperaturas elevadas. Já a laje de concreto apresenta temperaturas muito baixas, de modo que pode ser considerada com resistência total em ambos os casos, resultando numa contribuição da ordem de $20 \%$.

Nas regiões de momento negativo, a laje de concreto está toda tracionada e sua capacidade resistente é desconsiderada. Desse modo, as zonas tracionadas do perfil contribuem com $92 \%$ de sua resistência quando à temperatura ambiente. Porém, com o aumento de temperatura, as zonas comprimidas da seção passam a contribuir com $42 \%$ da resistência, em oposição a $58 \%$ das zonas tracionadas. Isso ocorre devido à mudança significativa da posição da LNP após a grande perda de capacidade resistente da mesa inferior do perfil. Como se pode notar, a posição da LNP é um fator determinante no momento resistente da seção, e também da parcela contribuinte de cada elemento, dessa forma, na Figura 2.7 é ilustrada a mudança da posição da LNP no decorrer do aquecimento, para as regiões de momento negativo e positivo.

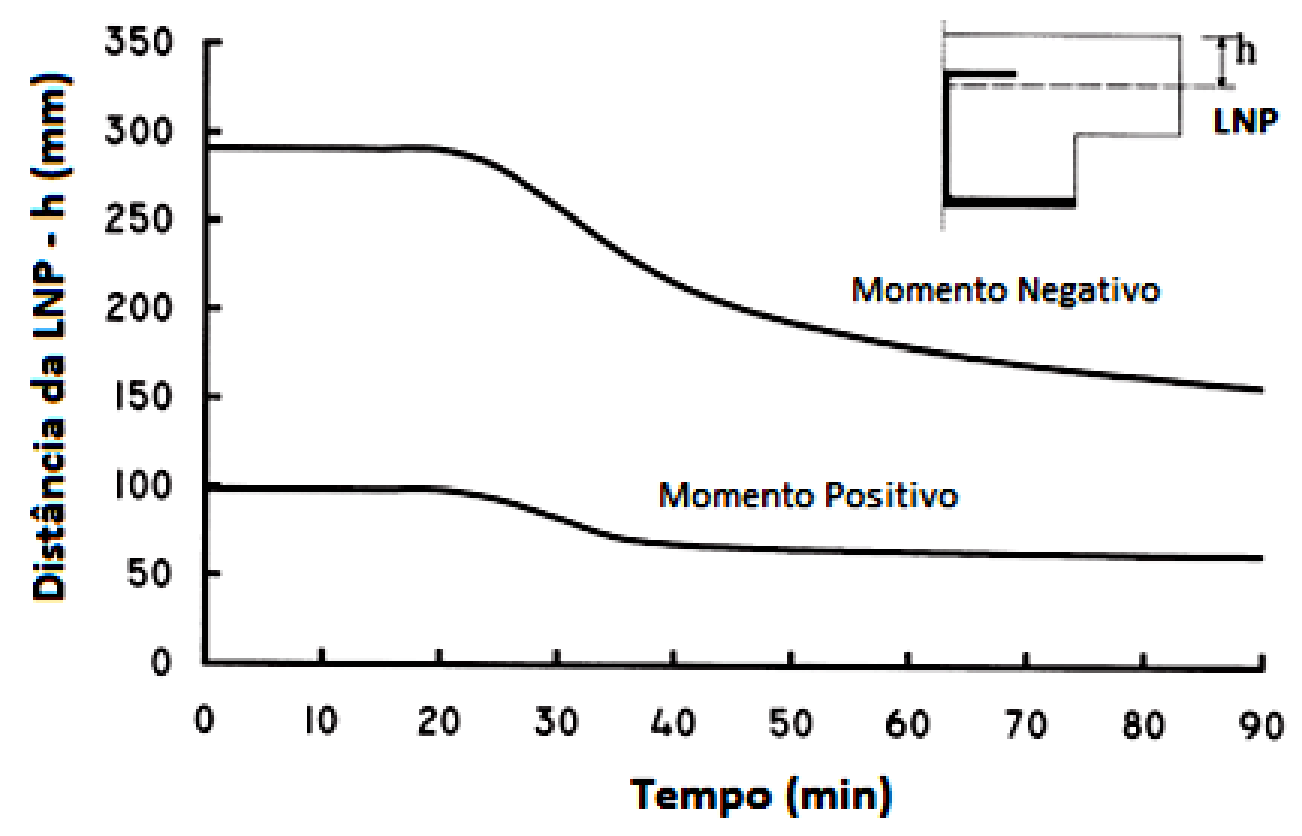

Figura 2.7 - Mudança da LNP com o decorrer do aquecimento, Mäkeläinen \& Ma (2000). 
É importante lembrar que no cálculo dos momentos resistentes em temperaturas elevadas não se utilizam os coeficientes de segurança dos materiais, pois o incêndio é considerado como uma ação excepcional. Mas para o valor de referência do fator de carga à temperatura ambiente os fatores de segurança devem ser utilizados. $O$ fator de carga é definido como a relação entre o momento resistente em temperatura elevada e à temperatura ambiente.

Ainda em Mäkeläinen \& Ma (2000) são desenvolvidas análises paramétricas, analisando fatores como o tipo de concreto, armadura de reforço, proteção contra o fogo na mesa inferior e o comportamento frente aos incêndios naturais. No que segue, são descritos alguns aspectos referentes aos materiais que compõem o sistema misto e as respectivas contribuições na resistência deste mesmo sistema frente à ação térmica.

Influência do tipo de concreto - Os concretos leves, por apresentarem menor inércia térmica, não são tão eficientes como revestimento térmico quanto os concretos normais e, dessa forma, apresentam momentos resistentes levemente inferiores aos concretos normais, como pode ser visto na Figura 2.8.

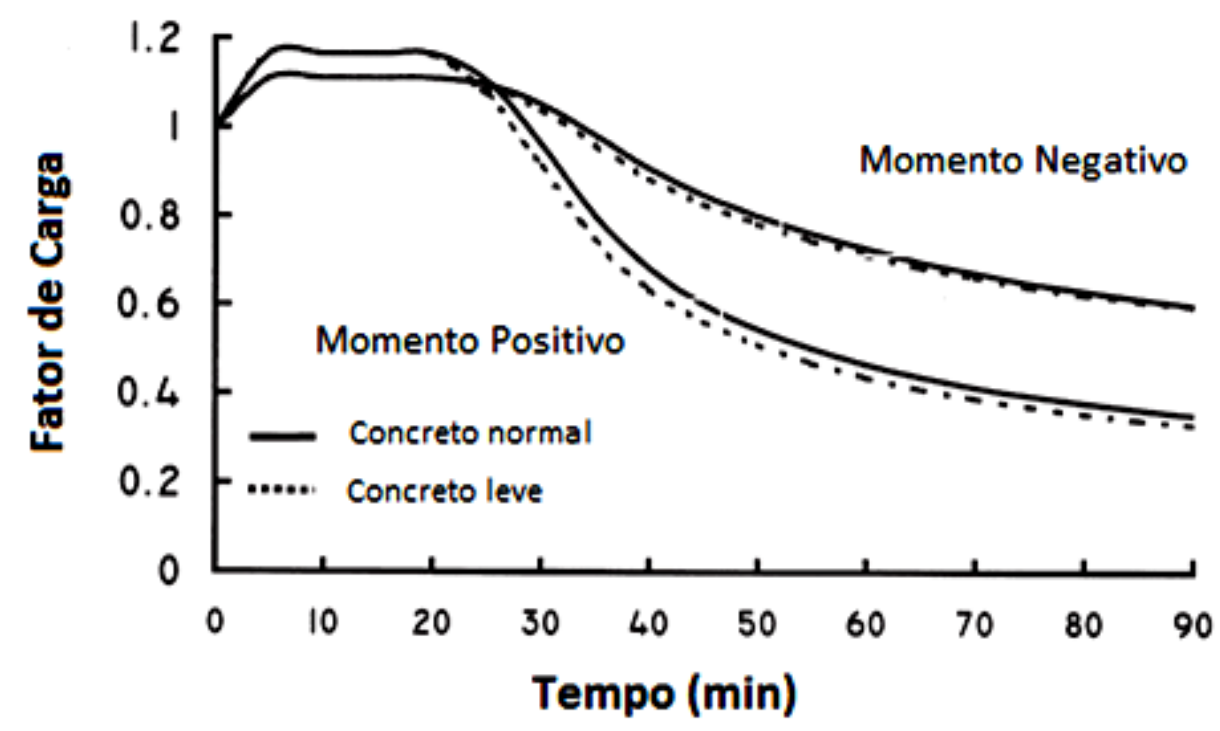

Figura 2.8 - Influência do tipo de concreto nos fatores de carga das vigas mistas de aço e concreto, Mäkeläinen \& Ma (2000).

Influência de reforço na armadura e do uso de revestimento contra fogo - A taxa de armadura da seção transversal não tem grande significância na capacidade 
resistente da viga, tendo em vista que um aumento considerável na taxa de armadura resulta em ganho de apenas $0,5 \%$ no momento resistente. Já o uso de revestimento contra fogo na mesa inferior do perfil tem grande influência na capacidade resistente da seção em temperaturas elevadas, de modo que foi obtido o fator de carga de 0,98 (praticamente capacidade total da seção) após os 60 minutos de exposição. Para 90 minutos o fator de carga ainda é elevado, sendo da ordem de 0,67 . Esses resultados são mostrados na Figura 2.9.

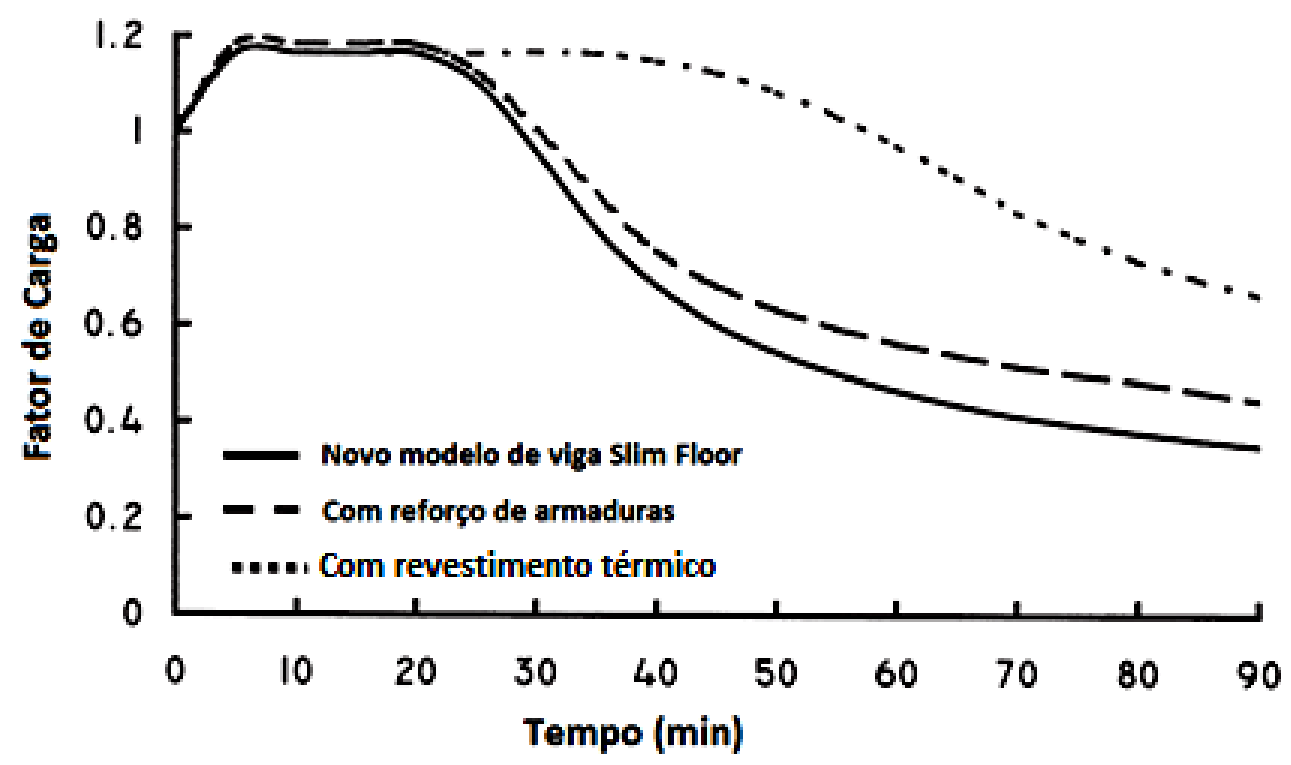

Figura 2.9 - Influência do reforço com armaduras e da proteção com pintura nos fatores de carga das vigas sob momento positivo, Mäkeläinen \& Ma (2000).

Comportamento estrutural sob a ação de incêndios naturais - Também foi analisado o aquecimento segundo as curvas de incêndio natural, apresentadas no anexo B do Eurocode1 Part 1.2, com parâmetros que caracterizavam uma situação crítica de incêndio. Outras curvas de incêndio natural são mostradas na Figura 2.10. A consideração de incêndios naturais visa aproximar as análises desenvolvidas das situações reais à qual o sistema estrutural pode estar submetido.

Para a análise termoestrutural utilizando as curvas de incêndio natural, devem ser levadas em conta as regiões de temperatura ascendente e descendente e, consequentemente, a irreversibilidade das propriedades mecânicas dos materiais com o resfriamento. No concreto, a resistência é determinada de acordo com a 
temperatura máxima atingida pelo material, ou seja, não há recuperação de resistência no resfriamento. Já para o aço, a sua resistência se baseia na temperatura atual do material, resultando na recuperação das suas propriedades iniciais após o resfriamento.

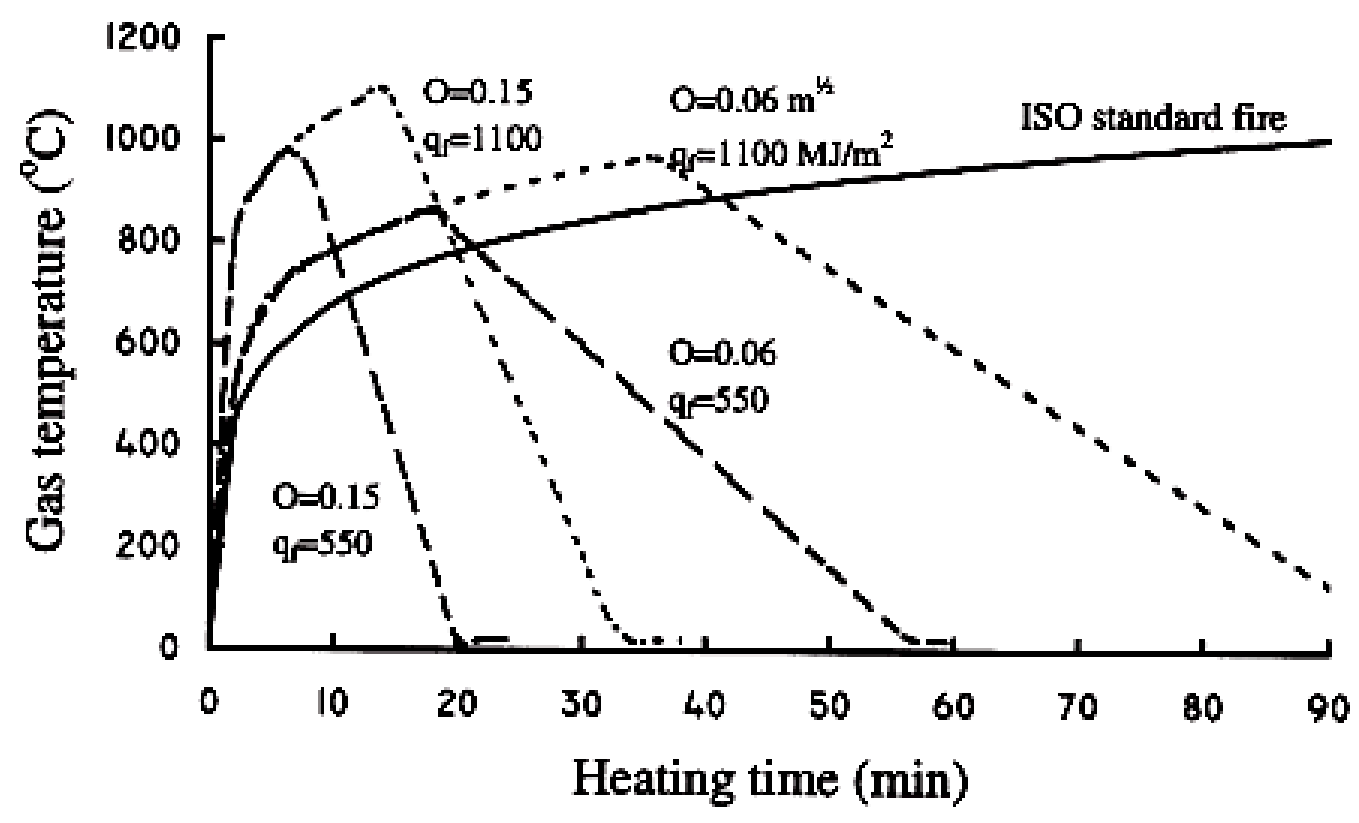

Figura 2.10 - Comparação do incêndio natural com o incêndio padrão, Mäkeläinen \& Ma (2000).

Analisando a influência dos parâmetros que definem um incêndio natural, foi constatado que o aumento da carga de incêndio resulta no colapso mais rápido da viga, mas, de maneira geral, as vigas dos pavimentos mistos de pequena altura podem ser utilizadas sem proteção ao fogo para cargas de incêndio inferiores a $1100 \mathrm{MJ} / \mathrm{m}^{2}$.

Visando tornar as análises numéricas mais próximas da condição real, analisando todos os fatores que são importantes nos modelos e evitando simplificações, em Schaumann \& Hothan (2002) se verificou a influência da troca de calor por radiação na cavidade das vigas do tipo Hat Beam (Figura 2.11), utilizando funções específicas do ABAQUS para a consideração desse efeito. $\mathrm{Na}$ mesma referência foi realizada a análise térmica bidimensional, seguida de cálculos em planilhas eletrônicas para a determinação do momento resistente via teoria plástica, como realizado em Newman (1995) e Mäkeläinen \& Ma (2000). 


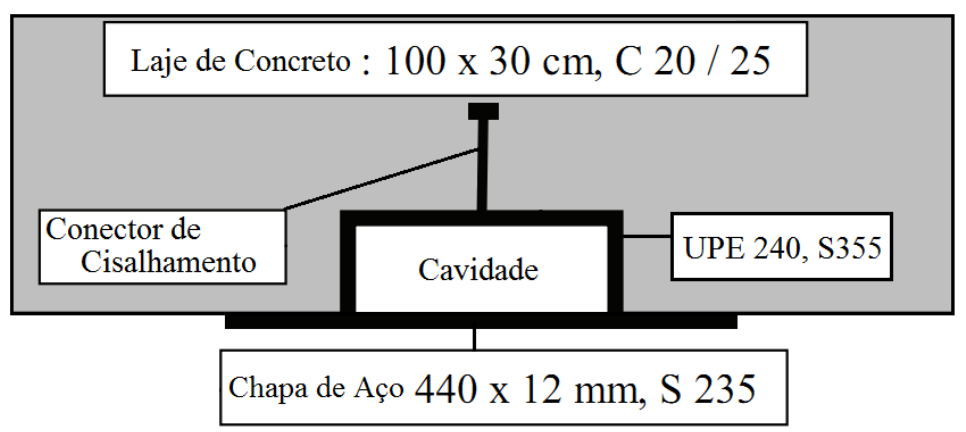

Figura 2.11 - Seção da viga analisada, Schaumann \& Hothan (2002).

Os resultados mostraram que a consideração da troca de calor na cavidade do perfil metálico causa diferenças significativas na capacidade resistente da seção transversal, principalmente para tempos de exposição ao fogo maiores que 60 minutos.

Como comentado, ao se considerar a estrutura sob efeito de incêndios naturais e a troca de calor por radiação em cavidades, busca-se aproximar ainda mais os resultados obtidos em análises numéricas dos resultados experimentais, e também dos que seriam encontrados na real situação de uso do elemento estrutural. Com este foco, algumas pesquisas (Bailey, 1999; Ma \& Mäkeläinen, 2000 e Dong \& Prasad, 2009) se interessaram em estudar situações que iam além da viga mista biapoiada e isolada sob o efeito do incêndio-padrão, situação essa que dificilmente será encontrada na prática.

No estudo apresentado em Ma \& Mäkeläinen (2006), foram realizadas análises de vigas slim floor em três situações distintas: uma primeira que se refere ao estudo da resistência ao fogo de vigas isoladas, uma segunda que trata da análise de pórticos planos com ligações semirrígidas, com a finalidade de avaliar o efeito da continuidade da viga e da interação entre os elementos do pórtico e, por fim, a terceira e última etapa que consiste da análise de uma estrutura tridimensional no sistema slim floor. Neste artigo foi realizada a análise numérica avançada por meio do código computacional ABAQUS, devido à maior complexidade das análises desenvolvidas.

Ma \& Mäkeläinen (2006) e Bailey (1999) chegaram à conclusão que a consideração das ligações semirrígidas melhora o comportamento estrutural das vigas slim floor. As análises numéricas apresentadas em Bailey (1999) foram desenvolvidas 
com o auxílio de um código computacional em elementos finitos especialmente criados para a análise de estruturas slim floor em situação de incêndio. Os elementos da viga e do pilar tem os seus graus de liberdade apresentados na Figura 2.12.

A partir do código computacional desenvolvido foram modeladas vigas simplesmente apoiadas com e sem ligações semirrígidas, sendo que em ambos os casos foi considerado o mesmo carregamento atuando sobre a viga $A$ análise prosseguiu até o instante em que a viga atingiu o deslocamento limite de $300 \mathrm{~mm}$, relativo à relação vão/20. Nota-se que a temperatura limite passa de $697^{\circ} \mathrm{C}$ para $798^{\circ} \mathrm{C}$ quando adotadas as conexões semirrígidas (Figura 2.13), apresentando uma melhora no comportamento estrutural do elemento.

Esse aumento de temperatura apresenta um ganho ainda maior em função do tempo de resistência ao fogo, onde o TRRF pode passar de 60 para 90 minutos. Além disso, Bailey (1999) cita que para casos onde há furos nas almas de vigas não superdimensionadas, a perda de TRRF (da ordem de 30 minutos) é compensada pela adoção das ligações semirrígidas. Porém, vale lembrar que a hipótese básica a ser considerada nessas análises é que toda a estrutura que envolve essa viga possa suportar o momento transferido através das ligações.

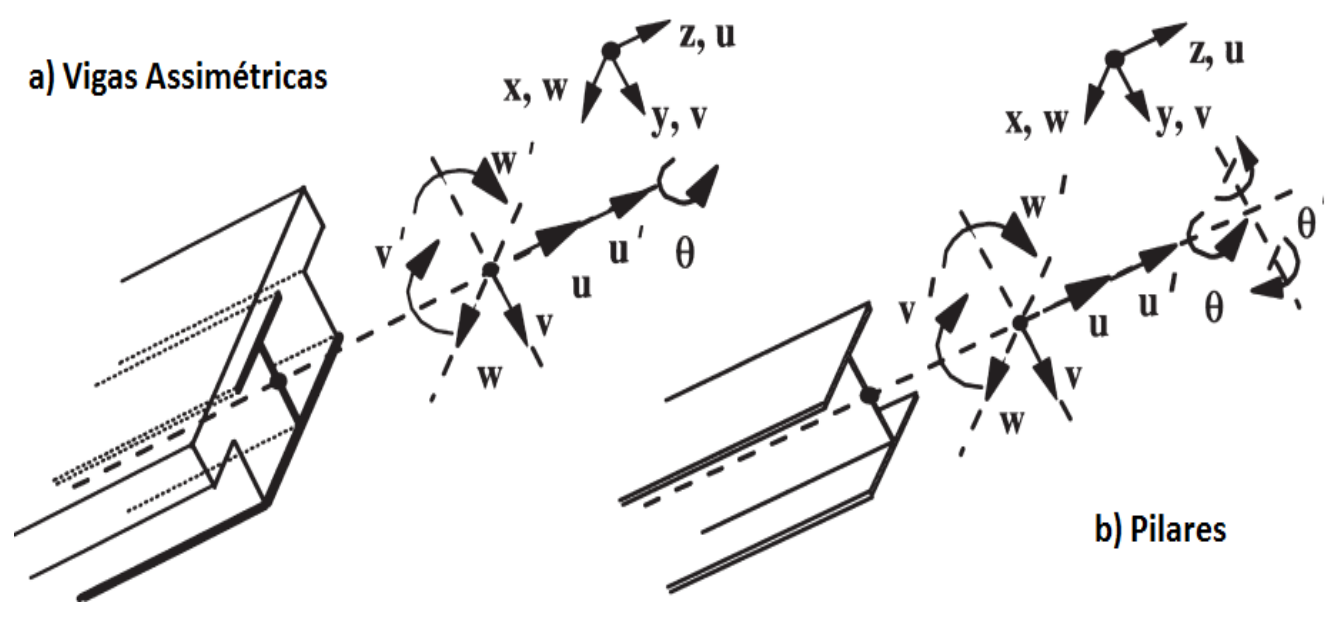

Figura 2.12 - Elementos finitos criados para as vigas e pilares do modelo, Bailey (1999). 


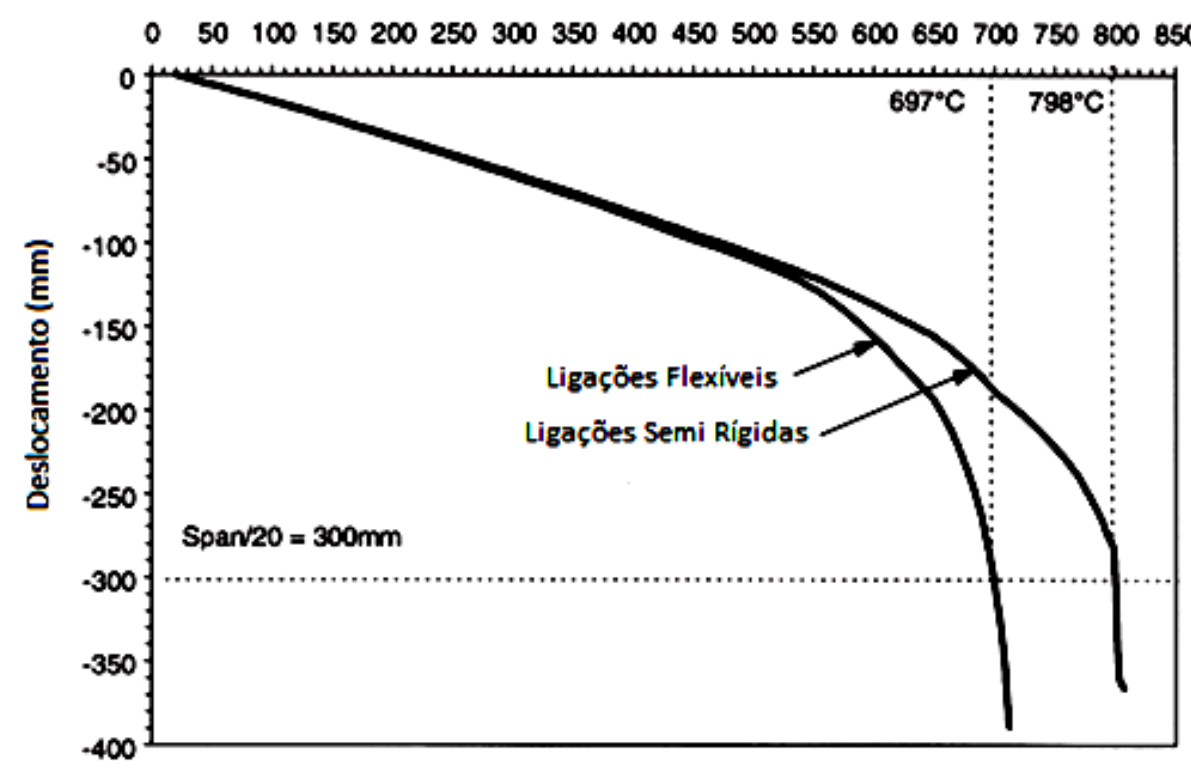

Figura 2.13 - Deslocamento vertical em função da temperatura da mesa inferior para as conexões simples e semirrígidas, Bailey (1999).

Ainda, considerando a análise de vigas pertencentes a pórticos planos, Dong \& Prasad (2009) realizaram a análise experimental de pórticos compostos por vigas com sistemas mistos convencionais e slim floor, como mostrados na Figura 2.14. Além dos diferentes tipos de vigas, os pórticos foram considerados com e sem proteção contra o fogo nos pilares.

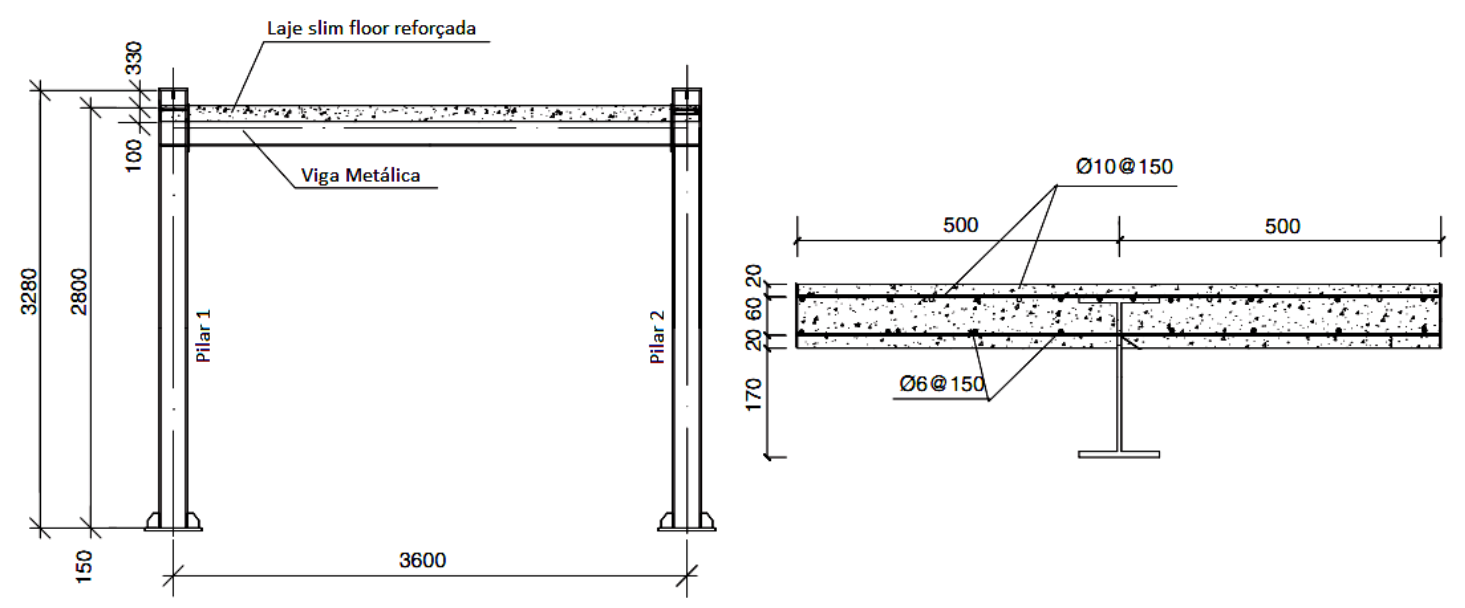

Figura 2.14 - Esquema dos ensaios utilizando vigas slim floor, Dong \& Prasad (2009). 
$\mathrm{Na}$ comparação entre os sistemas construtivos, os ensaios mostraram que os pórticos com o sistema slim floor resistiram a temperaturas maiores que os do sistema misto convencional. Já quando são comparados os resultados com sistemas construtivos iguais, mas com e sem proteção à ação térmica nos pilares, foi observado que, se os pilares não são revestidos, a estrutura resiste a menos tempo de exposição ao fogo, sendo a sua falha causada por instabilidade no pilar e não mais na viga.

Considerando agora a situação mais próxima da utilização real das vigas slim floor, em Ma \& Mäkeläinen (2006) é analisada a resposta estrutural de um pavimento tridimensional, mostrado na Figura 2.15, com ligações viga-pilar rotuladas. A carga aplicada consistia de um carregamento distribuído igual a $2,5 \mathrm{kN} / \mathrm{m}^{2}$ na laje mista que resulta em um fator de carga igual a 0,15 na mesma, sendo que tal carregamento é aplicado na viga a partir de 4 cargas concentradas, resultando em um fator de carga, para a viga, igual a 0,69 .

O piso manteve a estabilidade após 90 minutos de exposição ao aquecimento segundo a curva ISO e mostra que os deslocamentos relativos máximos entre a viga e a laje são pequenos, concluindo que a viga na estrutura tridimensional apresenta um desempenho bem melhor que a viga isolada, além de não ter apresentado o colapso verificado no caso da viga isolada.

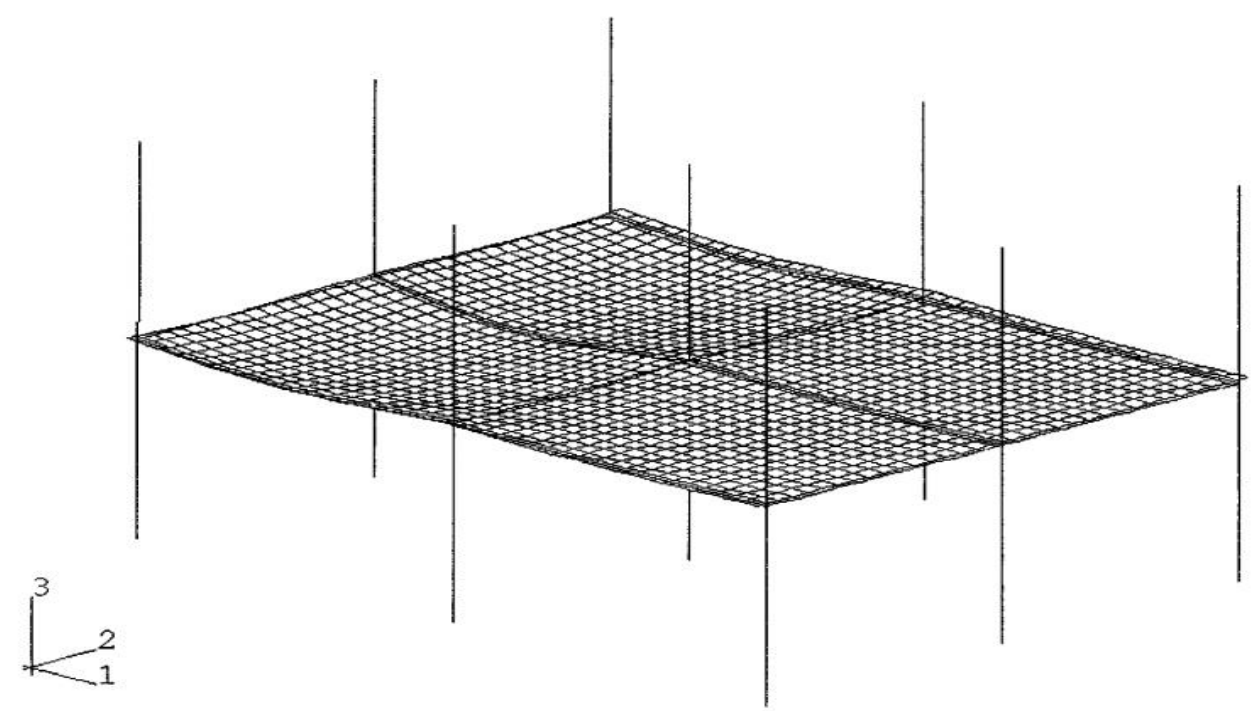

Figura 2.15 - Pavimento slim floor modelado em Ma \& Mäkeläinen (2006) 
Também é levado em consideração no modelo tridimensional que, as mesas inferiores das vigas de borda estão protegidas pelas paredes e fechamento do edifício. Quando as vigas estão protegidas não há degradação das propriedades físicas, garantindo maior restrição à laje de concreto. $\mathrm{Na}$ análise desse caso, o deslocamento vertical máximo na estrutura resultou menor quando comparado ao caso com as vigas de borda desprotegidas, observando assim que a proteção desses elementos também afeta a estabilidade das outras vigas expostas ao fogo. Esse ganho de estabilidade da estrutura está associado à possibilidade de a laje poder desenvolver o efeito de membrana na tração, fato que não se verifica no caso das vigas desprotegidas, pois as mesmas não possuíam capacidade resistente suficiente para tal.

A partir dos resultados apresentados em Bailey (1999), Ma \& Mäkeläinen (2000) e Dong \& Prasad (2009), pode-se concluir que para que a ação das restrições axiais e rotacionais nas extremidades das vigas seja benéfica para o seu comportamento estrutural, no sentido de aumentar o tempo resistente ao incêndio, as ligações viga-pilar e a estruturas que as envolvem devem ter capacidade resistente suficiente para responder aos esforços que serão transmitidos entre os elementos, para que a falha não ocorra em outro elemento que não seja a viga e também para que seja possível o desenvolvimento dos efeitos de membrana e catenária, que estabilizam os deslocamentos de lajes e vigas expostas à altas temperaturas.

Após quase 20 anos de estudos de vigas slim floor em situação de incêndio, verifica-se que já há uma técnica de modelagem (via elementos finitos) bastante consolidada no meio científico. Foi observado que grande parte dos trabalhos que contemplam análises numéricas utilizou o pacote computacional ABAQUS, que tem se mostrado bastante eficiente para a análise de estruturas mistas de aço e concreto em temperaturas elevadas.

Nesse contexto, os trabalhos apresentados em Maraveas et al. (2012) e Ellobody (2012), apresentam métodos de modelagem numérica bem definidos para a análise de vigas slim floor em situação de incêndio, apresentando resultados bastante satisfatórios na representação de análises experimentais, como é apresentado na Figura 2.16. Destaca-se que nos dois trabalhos em questão, a interface entre o aço e o concreto foi modelada por meio de elementos de contato considerando o modelo isotrópico de atrito de Mohr-Coulomb. 

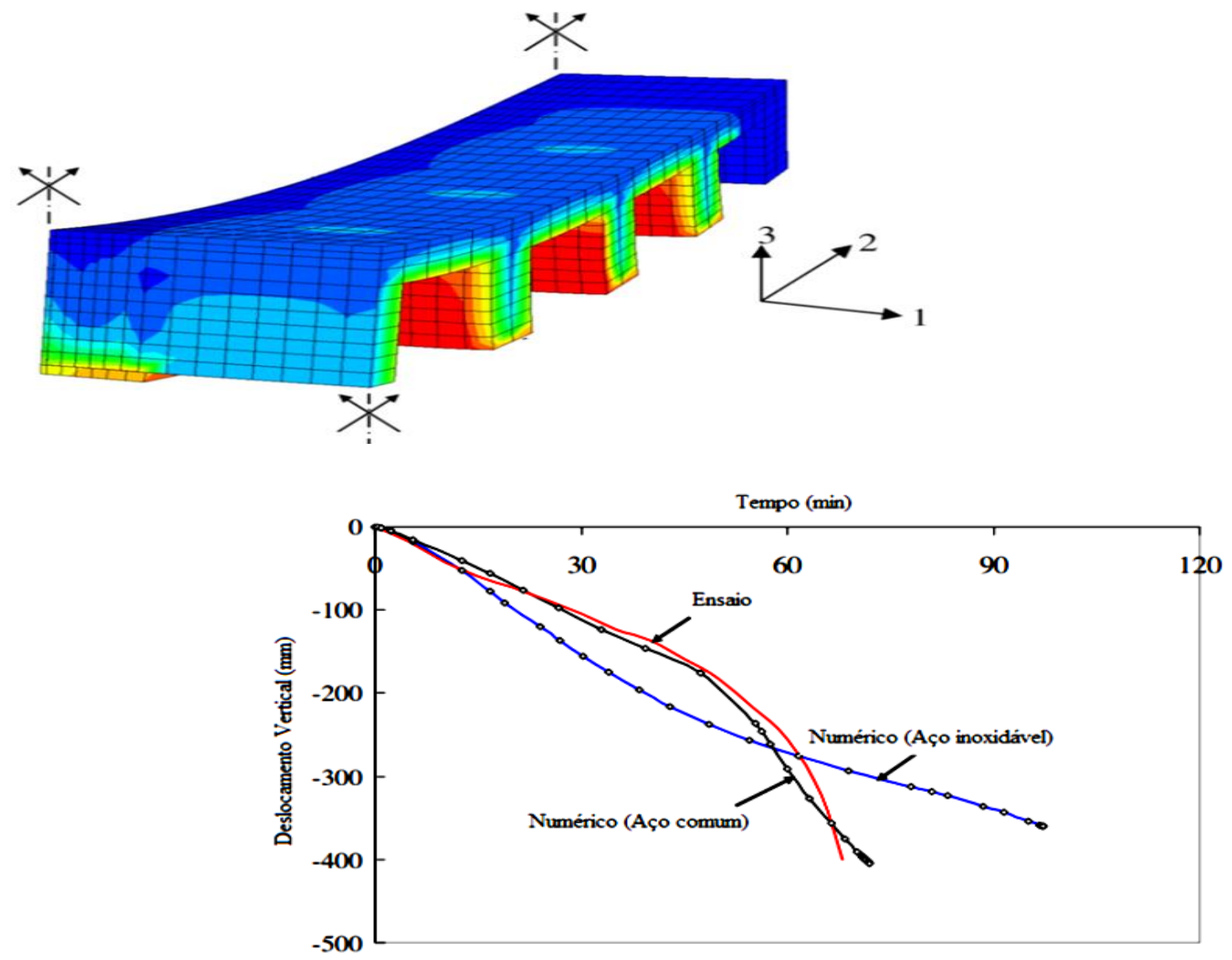

Figura 2.16 - Modelo numérico desenvolvido em Ellobody (2012) e comparação dos resultados numéricos com os experimentais, Ellobody (2012).

Os elementos utilizados consistiam de duas superfícies que podiam se deslocar relativamente entre elas, baseado nos coeficientes de atrito, mas sem ocorrer a penetração entre as mesmas. No que diz respeito ao coeficiente de atrito para modelar a interação entre o aço e o concreto, trata-se de tema que requer mais estudos, sendo que em Ellobody (2012) é sugerido um valor igual a 0,25, enquanto que em Maraveas et al. (2012) se sugere um valor igual a 0,5. Em Ellobody (2012) são apresentados resultados para vigas mistas formadas por perfis metálicos de aço inoxidável, apresentando uma melhora no comportamento frente às ações do fogo.

Também se destaca no contexto numérico os trabalhos de Park et al. (2012), Choi et al. (2012) e Rocha et al. (2013), onde foram utilizados outros pacotes computacionais, como o ANSYS, VULCAN e DIANA, respectivamente.

Como é possível observar pela análise da revisão bibliográfica a respeito dos pisos mistos de baixa altura em situação de incêndio, a maioria dos trabalhos se 
concentrou apenas em análises numéricas, em razão do elevado custo e a necessidade de equipamentos e mão de obra especializada para os ensaios em temperatura elevada.

Entretanto, alguns trabalhos realizaram a análise experimental de vigas slim floor. Dentre os já citados no presente texto, tem-se os trabalhos de Newman (1995), Lawson et al. (1997) e Dong \& Prasad (2009), que por sua vez, acabam se tornando os resultados utilizados para a validação de modelos numéricos. Destaque especial deve ser dado a Lawson et al. (1997), cujos ensaios são citados em quase todos os trabalhos que foram descritos no presente capítulo.

Esse fato mostra a carência de estudos experimentais a respeito das vigas slim floor, principalmente em situações que vão além do caso das vigas biapoiadas submetidas ao incêndio-padrão. Os ensaios mais recentes abordando vigas parcialmente revestidas em temperatura elevada são os apresentados em Kim et al. (2011) e Park et al. (2012), e listrados por meio da Figura 2.17. Os ensaios citados na última referência foram desenvolvidos na Coréia do Sul, onde foram realizados ensaios em vigas com perfis assimétricos disponíveis no mercado Sul-coreano e laje de concreto com fôrma metálica incorporada, considerando diferentes situações de carregamento e fatores de carga.
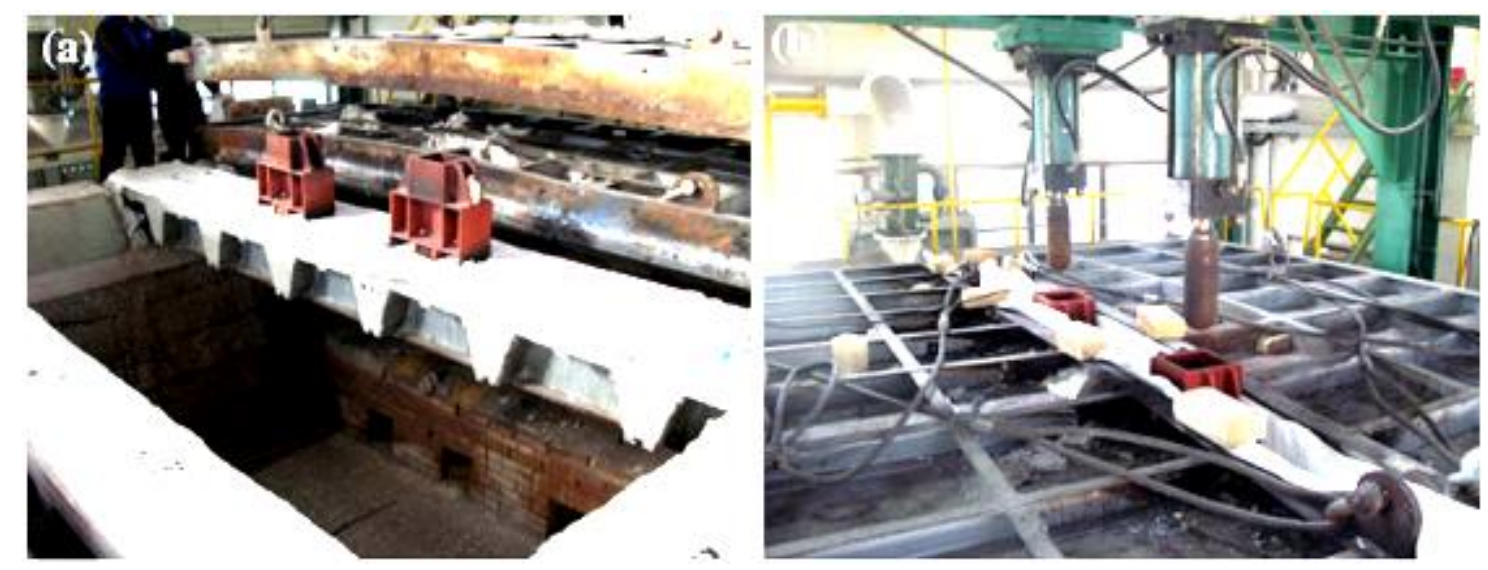

Figura 2.17 - Ensaios termoestruturais em vigas slim floor, Kim et al. (2011).

Em Hosser (1994) foram realizadas análises experimentais e numéricas em vigas mistas convencionais simplesmente apoiadas considerando também a laje de 
concreto. Foi realizado também um estudo teórico para estimar a largura efetiva da laje em vigas mistas em situação de incêndio, utilizando também análises numéricas. A influência da armadura da laje na resistência ao fogo e a propagação de fissuras foram examinadas.

Nos estudos foi dado ênfase na largura efetiva que deveria ser considerada na laje para a verificação em temperatura elevada, devido à significativa mudança na distribuição de tensões após o aquecimento. Ao final do trabalho, foi confirmado que a largura efetiva da laje pode ser considerada também para o dimensionamento em temperatura elevada de vigas mistas parcialmente revestidas, contanto que a laje esteja com conectores e armadura suficientes para suportar as condições de projeto à temperatura ambiente.

Segundo Kodaira et al. (2004), a distribuição de tensões nas vigas mistas parcialmente revestidas terá grande influência do tamanho da seção transversal dos elementos, pois está diretamente ligada com a distribuição de temperatura após um determinado intervalo de tempo. Tendo em vista esse comportamento, em Kodaira et al. (2004) foi realizado uma série de ensaios em vigas parcialmente revestidas considerando diferentes seções transversais, com e sem a laje de concreto acoplada. Todas as vigas foram ensaiadas na condição biapoiada, com o carregamento aplicado nos terços do seu vão.

No que diz respeito aos campos térmicos, pode ser visto na Figura 2.18 que a mesa inferior dos perfis metálicos tem um rápido acréscimo de temperatura, independentemente da consideração da laje, apresentando temperaturas bem próximas da curva de incêndio-padrão.

No caso da mesa superior, quando não foi considerada a laje de concreto, a mesa foi revestida com material isolante para manter o aquecimento apenas em três faces. Foi observado que, nesse caso, as temperaturas apresentadas na mesa superior resultam maiores quando não é considerada a laje de concreto, mesmo não recebendo calor diretamente, isso ocorre, pois a laje de concreto rouba calor da seção transversal. A alma do perfil metálico é a região que apresenta temperaturas menores na seção transversal, de modo que quanto maior a largura da seção, menor é a temperatura da alma do perfil metálico. 


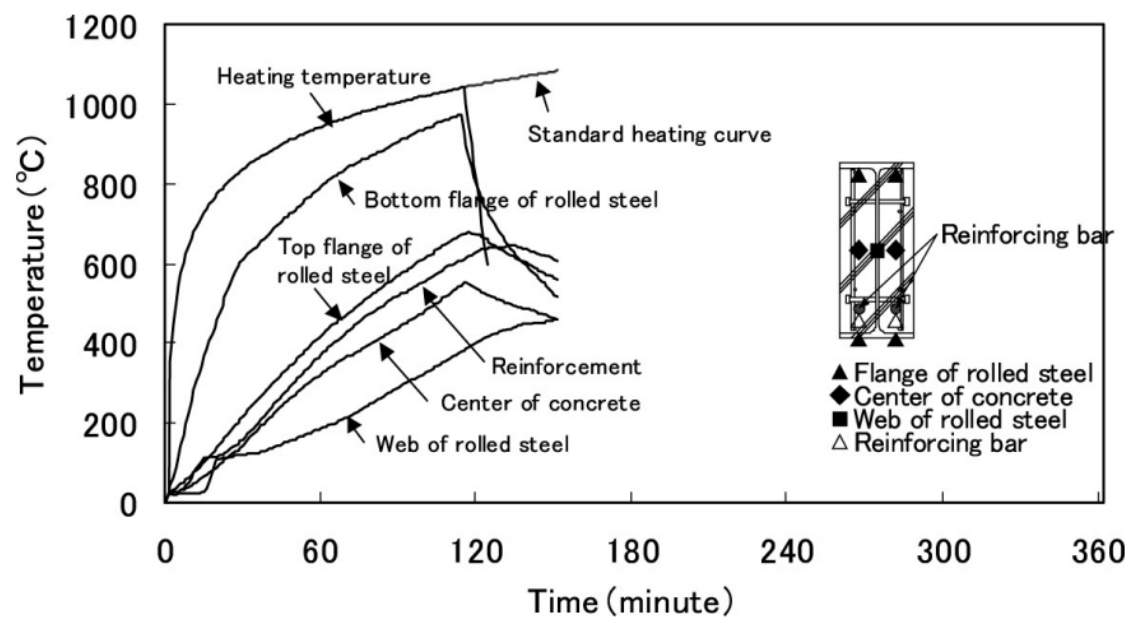

Figura 2.18 - Variação de temperatura na seção transversal, Kodaira et al. (2004).

Entre os elementos mistos parcialmente revestidos ensaiados sem a laje de concreto, foram analisados casos com e sem reforço no concreto entre as mesas. Foi observado por Kodaira et al. (2004) que os casos com reforço apresentaram deslocamentos no meio do vão bem menores que o modelo sem reforço, demorando de 14 a 23 minutos mais para atingir os critérios de parada do ensaio. Em todos os ensaios não foram observados danos no elemento até o instante em que foram atingidos os critérios de parada da ISO 834:1999, mas somente após mais algum tempo exposto ao fogo. Para vigas de dimensões usuais, considerando um fator de carga de 0,33 , foram encontradas resistências ao fogo que variaram de 80 a 242 minutos, sendo os maiores tempos encontrados nos elementos ensaiados com a laje de concreto e com maior quantidade de reforço.

Por fim, é apresentado o trabalho de Piloto et al. (2013), contemplando exclusivamente as vigas mistas parcialmente revestidas sem a consideração da laje de concreto, situação que foi analisada nesta presente dissertação. A viga foi ensaiada em modelo reduzido e na posição vertical com $100 \mathrm{~mm}$ de altura e o vão de 1210 mm, como pode ser visto na Figura 2.19.

Foram realizados três ensaios à temperatura ambiente e 12 ensaios em temperatura elevada, para diferentes níveis de carga $(0,37,0,56$ e 0,74) e condições de ligação dos estribos com a alma do perfil metálico (soldado e não soldado). Os 
resultados apresentaram boa reprodutibilidade. Em relação aos modos de falha, rótulas plásticas foram observadas nos ensaios para fatores de carga mais baixos, apresentando maiores temperaturas e, portanto, maiores reduções na resistência. Nos ensaios com o fator de carga igual a 0,74 foi observada instabilidade lateral.

(a)

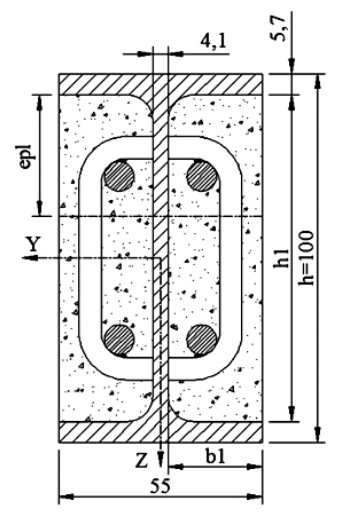

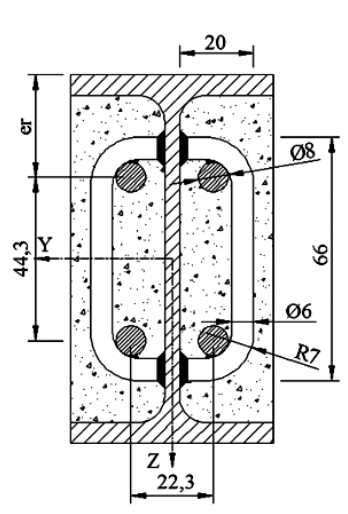

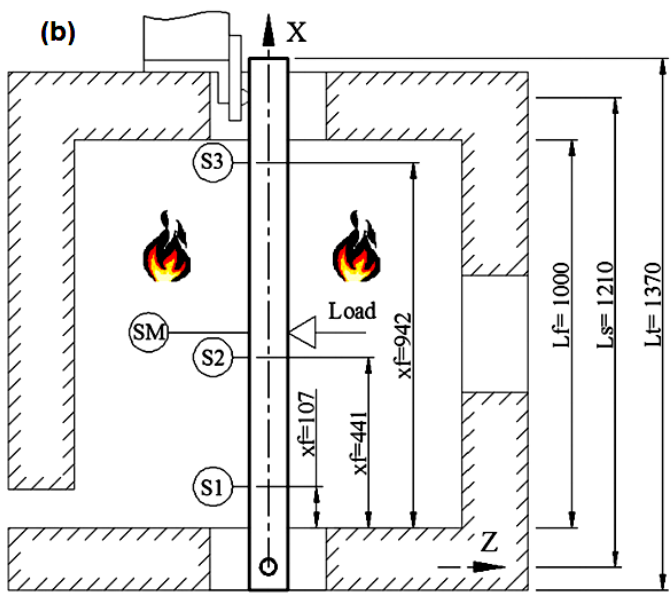

Figura 2.19 - Seção transversal e esquema de ensaio, Piloto et al. (2013).

Em relação às temperaturas, foi observado comportamento semelhante ao descrito em Kodaira et al. (2004), com temperatura da alma inferior à das mesas. Entretanto, em Piloto et al. (2013), o aquecimento foi realizado em todas as faces da viga.

Devido ao aquecimento realizado em todas as faces e a pequena dimensão dos elementos ensaiados, os tempos de resistência ao fogo variaram de 18 a 25 minutos, bem pequenos quando comparados com os resultados de Kodaira et al. (2004). Não foram obtidas maiores conclusões a respeito do uso de estribos soldados ao perfil metálico ou não. Apesar de um programa experimental bem desenvolvido, as conclusões obtidas acerca do comportamento estrutural de vigas parcialmente revestidas em situação de incêndio não podem ser estendidas para casos em tamanho real, necessitando de maiores estudos para tal associação. Em Piloto et al. (2011) é apresentado o modelo numérico validado a partir desses ensaios utilizando o pacote computacional ANSYS. 


\section{Capítulo 3}

\section{PROGRAMA EXPERIMENTAL: VIGAS \\ DE AÇO E MISTAS}

\subsection{Informações Preliminares}

Neste capítulo são apresentados os ensaios realizados em vigas de aço e mistas de aço e concreto, cujo programa experimental foi dividido em duas etapas: (1) ensaios à temperatura ambiente e (2) ensaios em temperaturas elevadas.

Os ensaios à temperatura ambiente tiveram como finalidade determinar, entre outros aspectos, a capacidade resistente de vigas de aço e mistas de aço e concreto parcialmente revestidas. Em contrapartida, nos ensaios em temperaturas elevadas, realizados no forno horizontal a gás, buscou-se avaliar a resistência ao fogo dessas mesmas vigas, considerando aplicação de carregamento e a influência do preenchimento, com concreto, da região entre as mesas nos perfis metálicos.

Dentro desse mesmo contexto, no que segue será apresentado o detalhamento do sistema experimental, as características e particularidades das vigas ensaiadas, a instrumentação utilizada, a caracterização dos materiais utilizados, bem como os resultados obtidos. 


\subsection{Características dos elementos}

Basicamente, o programa experimental compreendeu ensaios de vigas de aço e mistos de aço e concreto parcialmente revestidas, dentro do qual foram realizados 6 ensaios e foram avaliadas vigas à temperatura ambiente, em temperatura elevada, bem como diferentes fatores de carga.

As vigas que foram ensaiadas durante o programa experimental, as quais seguem como referência os modelos desenvolvidos e analisados em Piloto et al. (2013), resultaram de perfis metálicos isolados constituídos de seção transversal do tipo "I", bem como vigas mistas com preenchimento de concreto e armaduras entre as mesas e a alma.

O perfil metálico foi escolhido de forma a representar uma seção aplicável, enquanto elemento, em um edifício de múltiplos pavimentos, sendo então adotado o perfil laminado W $250 \times 32,7$, que apresentou capacidade resistente suficiente para suportar ações que ocorrem nesse tipo de edificação, conforme as prescrições da ABNT NBR 8681:2003, bem como possuíssem mesas com comprimento suficiente para acomodar as barras de armadura e os estribos, respeitando os cobrimentos e taxas mínimas da ABNT NBR 6118:2014.

As vigas ensaiadas possuíam $6000 \mathrm{~mm}$ de comprimento e $5100 \mathrm{~mm}$ de vão livre entre os apoios. Em relação à armadura nas vigas mistas de aço e concreto, foram adotadas quatro barras longitudinais de diâmetro 6,3 $\mathrm{mm}$ juntamente com estribos de um ramo e $5 \mathrm{~mm}$ de diâmetro, os quais foram soldados na alma do perfil metálico, espaçados de $15 \mathrm{~cm}$, como mostram as Figuras 3.1 e 3.2.
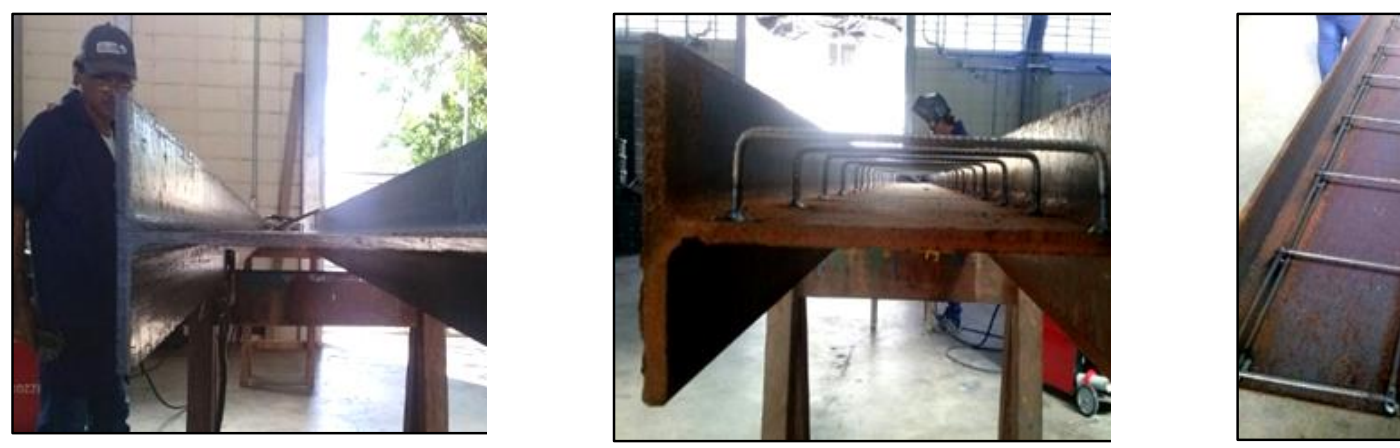

Figura 3.1 - perfil metálico "l” e armaduras soldadas nas vigas mistas 

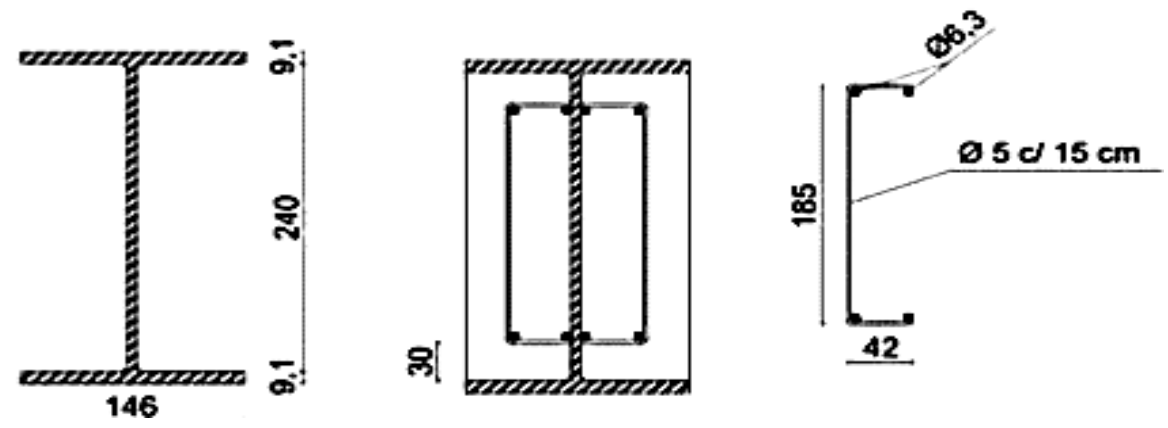

Figura 3.2 - Modelos utilizados com detalhamento das armaduras

$\mathrm{Na}$ tabela 3.1 é apresentado a quantidade de ensaios e o que se difere em cada um deles no programa experimental realizado.

Tabela 3.1 - Resumo programa experimental -

Quantidade de ensaios e o que difere entre eles

\begin{tabular}{|c|c|c|}
\hline \multicolumn{3}{|c|}{ Ensaio à Temperatura Ambiente } \\
\hline Ensaio 1 & \multicolumn{2}{|c|}{ Perfil Metálico } \\
\hline Ensaio 2 & Perfil Misto \\
\hline Ensaio em Temperaturas Elevadas \\
\hline Ensaio 4 & Perfil Metálico & $\begin{array}{c}\text { Fator de Carga aplicado: } \\
30 \%\end{array}$ \\
\hline Ensaio 5 & Perfil Misto & $\begin{array}{c}\text { Fator de Carga aplicado: } \\
30 \%\end{array}$ \\
\hline Ensaio 6 & Perfil Misto & $\begin{array}{c}\text { Fator de Carga aplicado: } \\
30 \%\end{array}$ \\
\hline
\end{tabular}




\subsection{Concretagem, moldagem, adensamento e cura}

A concretagem foi realizada em duas etapas, uma para cada lado do perfil, com diferença de sete dias entre elas. Tendo em vista a necessidade de ensaiar os elementos considerando o pouco espaço de tempo para as concretagens, no caso sete dias, foi utilizado o cimento CPV - ARI. A Figura 3.3 ilustra a produção do concreto moldado no local (laboratório da EESC).
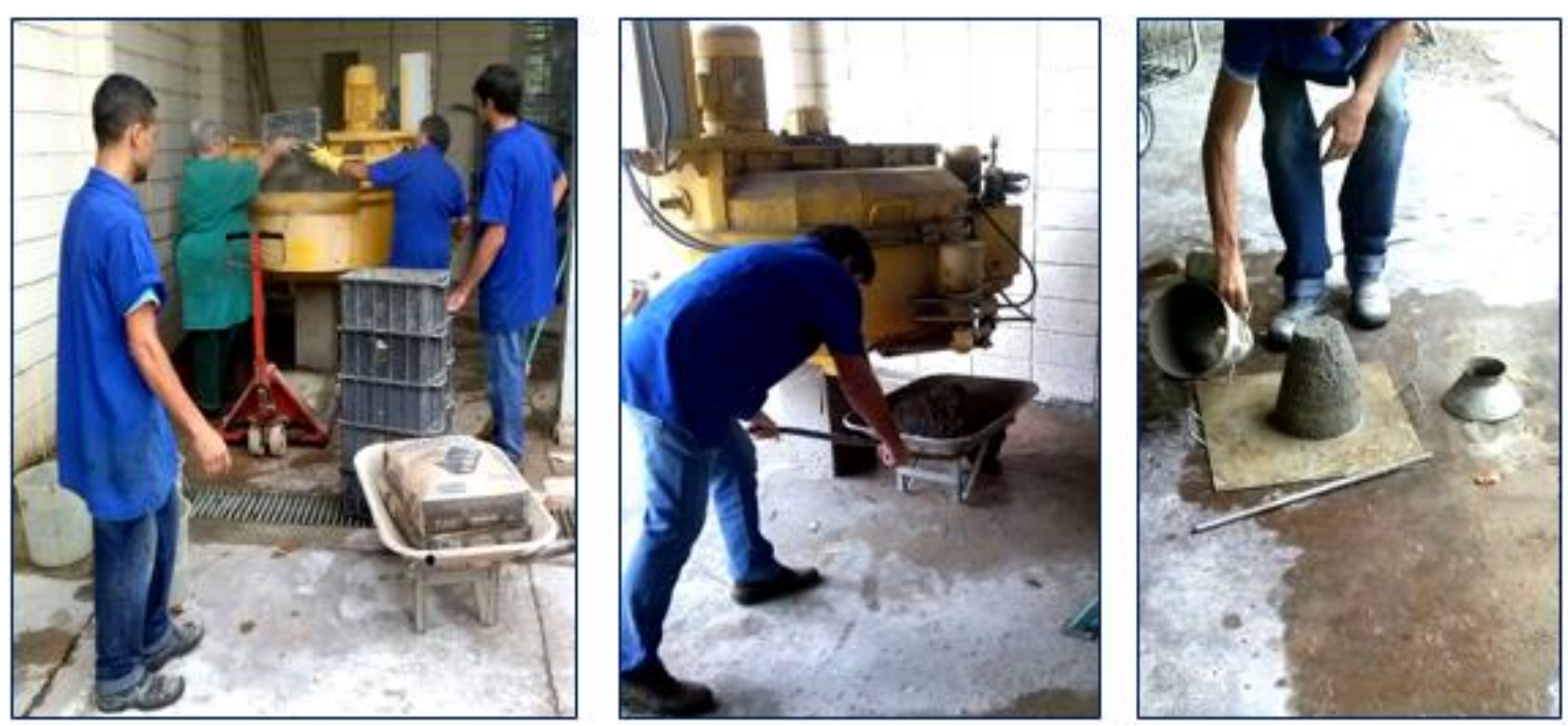

Figura 3.3 - Produção do concreto e teste de abatimento do tronco de cone

O traço do concreto adotado, em massa, foi de $1: 1,36: 2,10: 0,36$ (proporções em massa de cimento, areia, brita e água, respectivamente). Vale ressaltar que foi utilizado também um aditivo superplastificante na proporção de $3 \%$ em massa, com a finalidade de diminuir a quantidade de água no concreto. Na tabela 3.2 que seguem é apresentada as etapas de moldagem, adensamento, cura e parte da instrumentação voltada às vigas mistas. 
Tabela 3.2 - Etapas de ensaios referentes à vigas mistas de aço e concreto

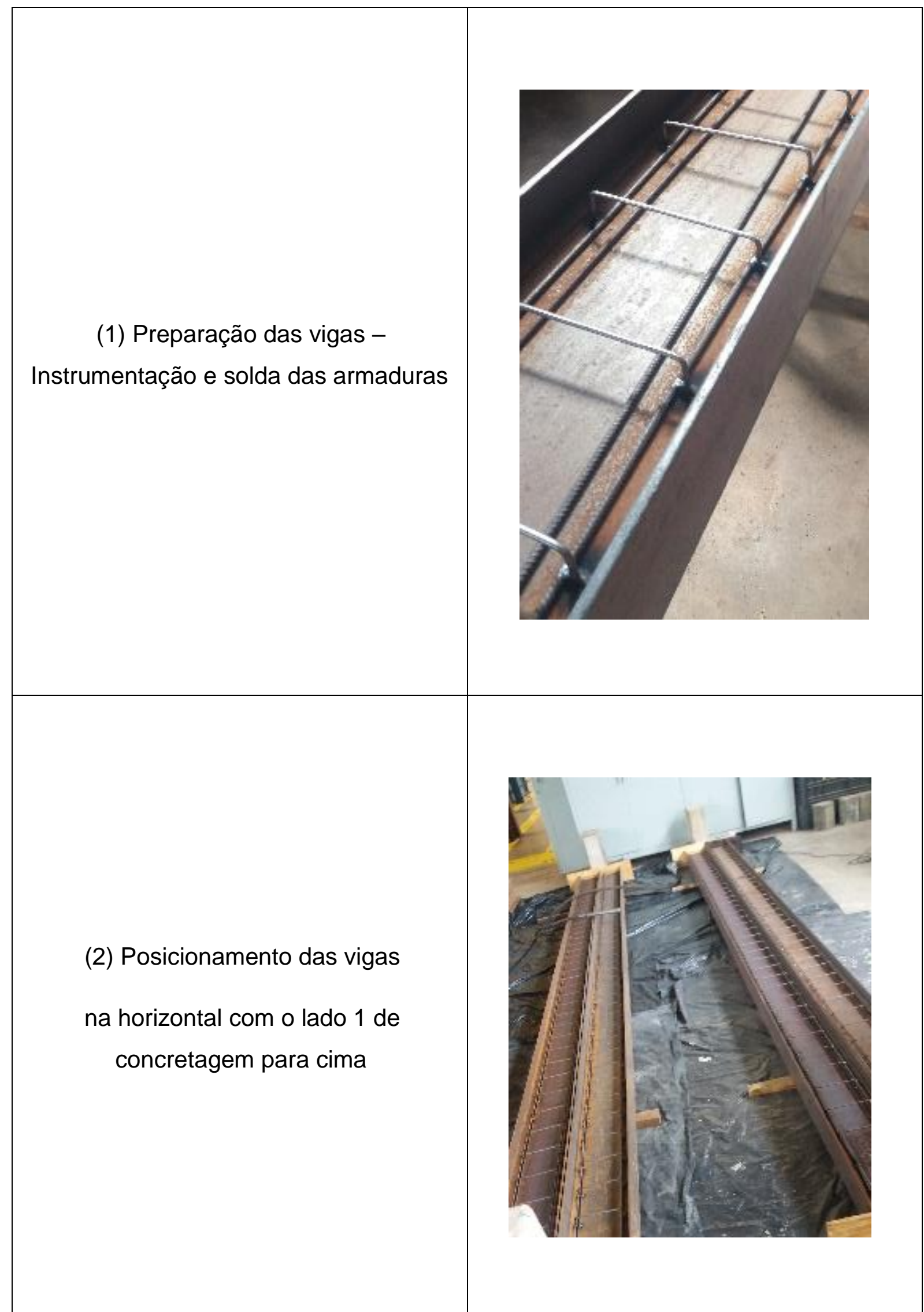


(3) Lado 1 - Concretagem e adensamento utilizando vibrador de agulha.
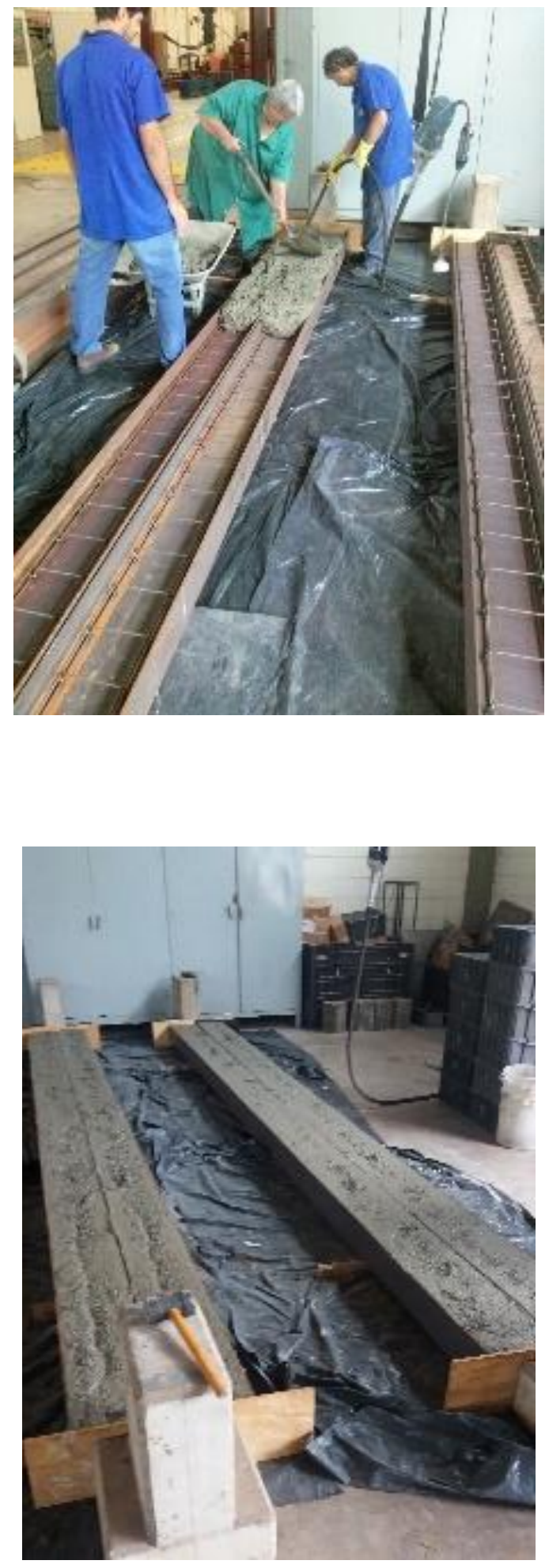


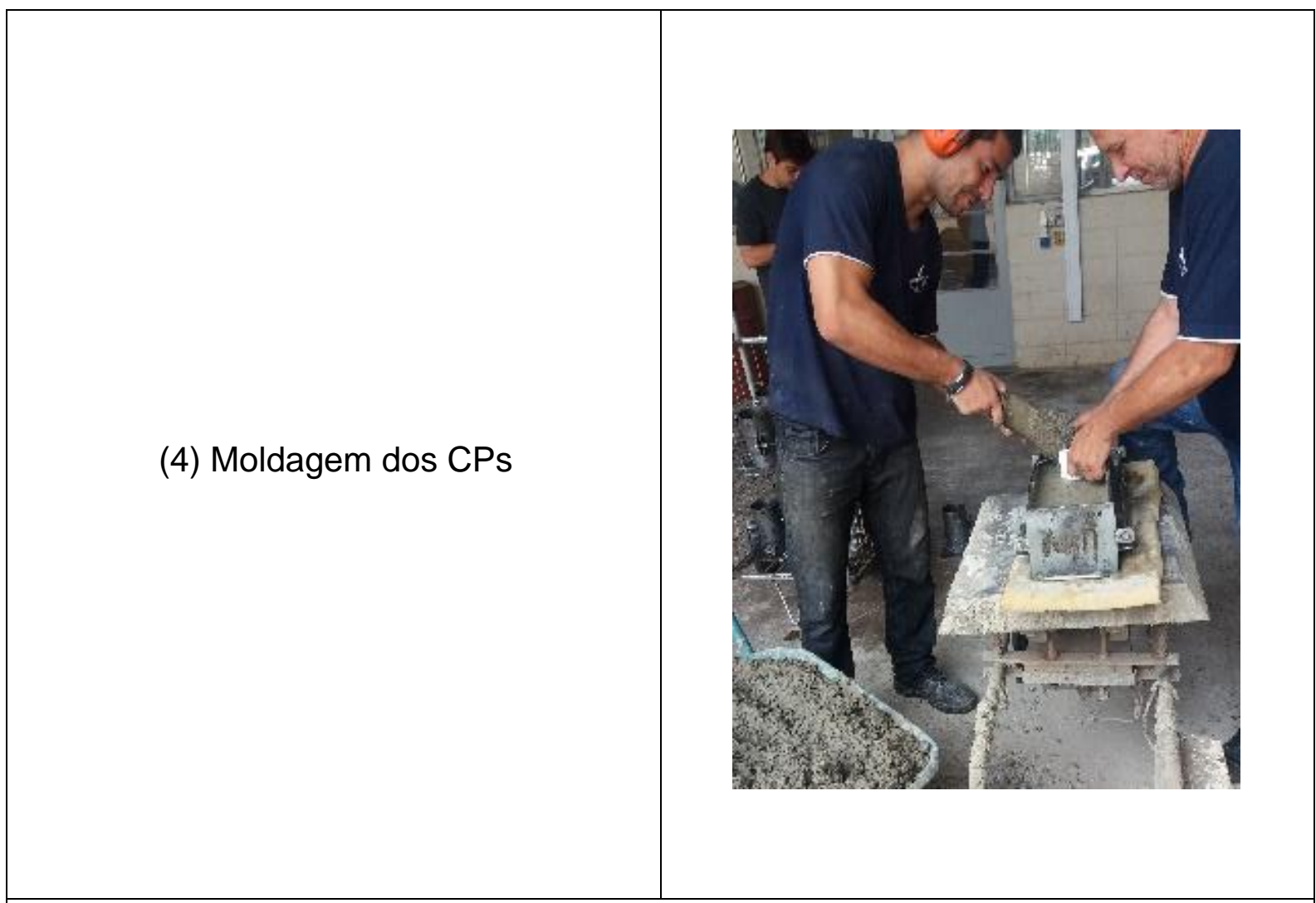

(5) Cura das vigas no galpão de ensaios cobertos por lona, para evitar perda prematura de água, por 7 dias.

(6) Posicionamento das vigas

na horizontal com o lado 2 de concretagem para cima

(7) Lado 2 - Concretagem e adensamento utilizando vibrador de agulha.

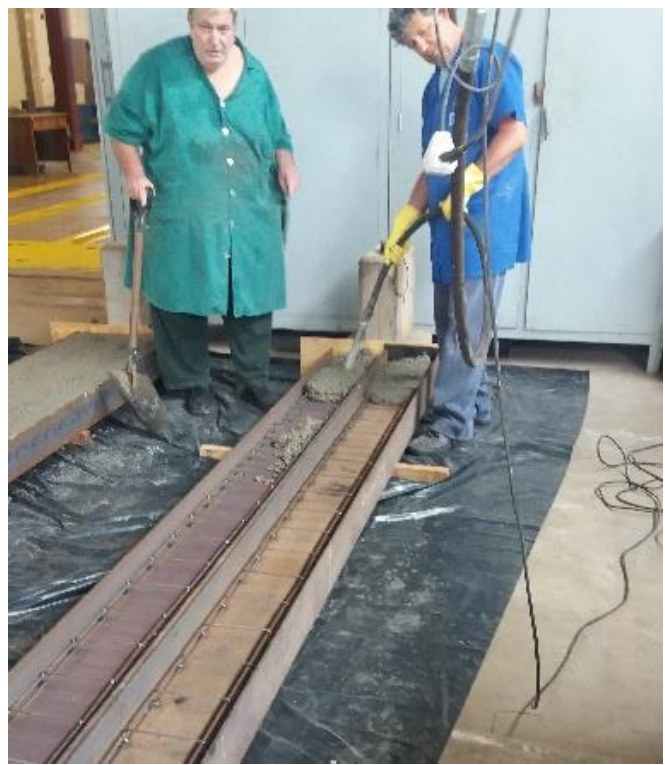

(8) Moldagem dos CPs 
(9) Cura das vigas no galpão de ensaios cobertos por lona, para evitar perda prematura de água, por 28 dias.

(10) Instrumentação das faces expostas do concreto

\subsection{Caracterização dos materiais}

Neste item será detalhada a metodologia utilizada para determinar algumas das propriedades mecânicas dos materiais utilizados nas vigas em estudos. São eles: aço do perfil, da armadura e o concreto. Os resultados encontrados também estão descritos nesses mesmos itens.

\subsubsection{Referente ao concreto utilizado}

Para a determinação da resistência à compressão do concreto, foram moldados três corpos de prova cilíndricos em cada concretagem, os quais foram ensaiados segundo recomendações da ABNT NBR 5739:2007, conforme ilustrado na Figura 3.4.
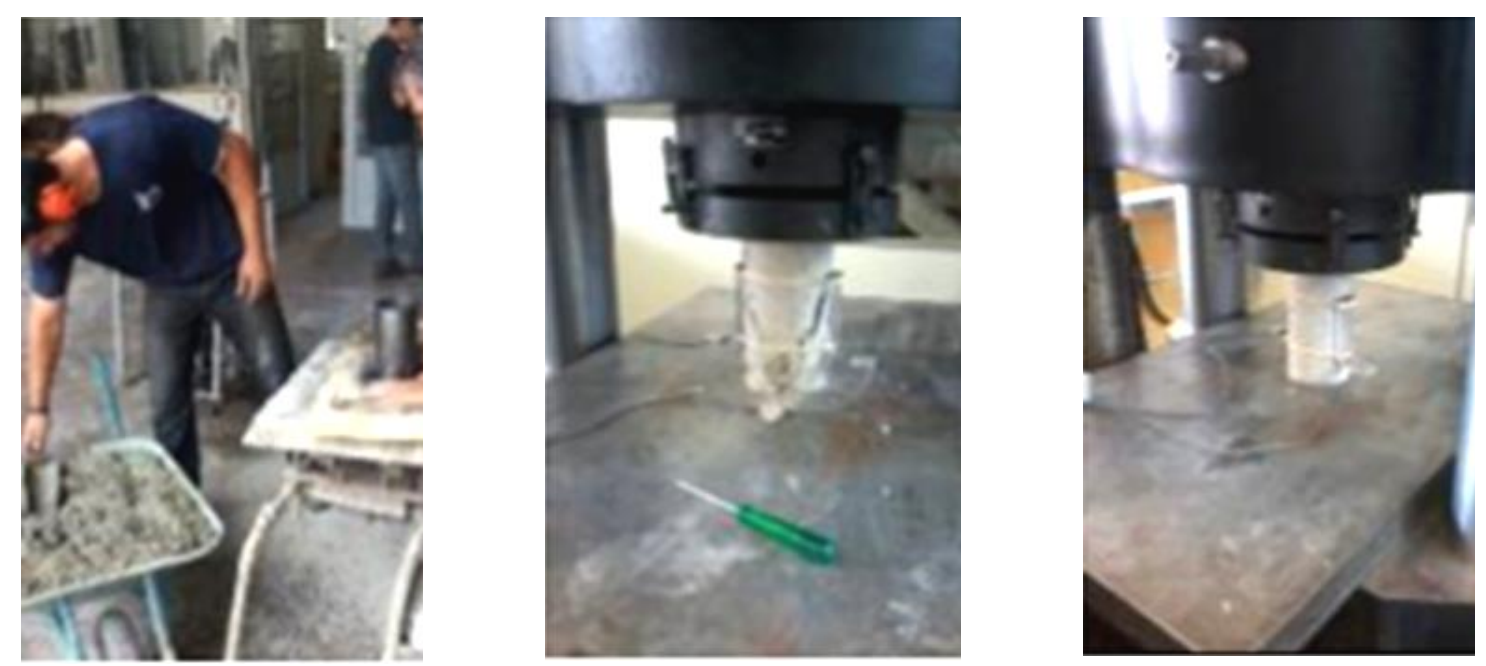

Figura 3.4 - Moldagem dos corpos de prova e ensaio de compressão

A aplicação da compressão foi desenvolvida até o momento de ruptura do concreto, de modo que o registro dessa mesma força possibilitou a determinação da 
resistência à compressão (em MPa) cujos dados são apresentados na Tabela 3.3. Para a determinação da resistência à tração, foram utilizados três corpos de prova cilíndricos para cada concretagem, seguindo as recomendações da ABNT NBR 7222:2011, conforme ilustra a Figura 3.5.

Foi aplicada uma força de compressão diametral até o momento de ruptura do concreto e, através do registro dessa mesma força, determinou-se a resistência à tração desse mesmo material, em MPa, cujos dados estão na Tabela 3.4.

Tabela 3.3 - Valores de resistência à compressão dos corpos de prova

\begin{tabular}{|c|c|c|c|c|}
\cline { 2 - 5 } \multicolumn{1}{c|}{} & \multicolumn{2}{c|}{1 1 concretagem } & \multicolumn{2}{c|}{$2^{\underline{a} \text { concretagem }}$} \\
\hline CP & $\begin{array}{c}\text { Força máxima } \\
(\mathrm{kN})\end{array}$ & $\begin{array}{c}\text { Resistência à } \\
\text { compressão } \\
(\mathrm{MPa})\end{array}$ & $\begin{array}{c}\text { Força } \\
\text { máxima } \\
(\mathrm{kN})\end{array}$ & $\begin{array}{c}\text { Resistência à } \\
\text { compressão } \\
(\mathrm{MPa})\end{array}$ \\
\hline CP 1 & 496,368 & 63,20 & 490,187 & 62,41 \\
\hline CP 2 & 505,891 & 64,41 & 499,069 & 63,54 \\
\hline CP 3 & 504,197 & 64,20 & 485,197 & 61,78 \\
\hline & Média & 63,94 & Média & 62,58 \\
\hline
\end{tabular}



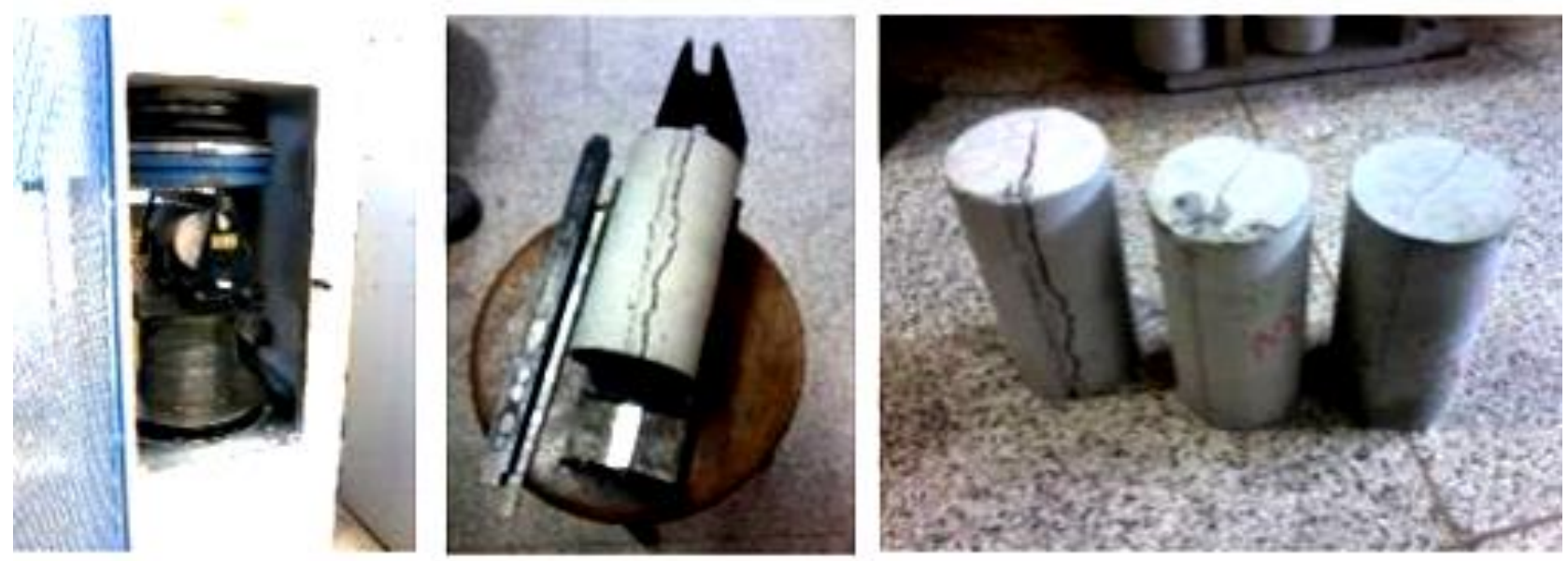

Figura 3.5 - Ensaio de compressão diametral

Tabela 3.4 - Valores de resistência à tração dos corpos de prova

\begin{tabular}{|c|c|c|c|c|}
\cline { 2 - 5 } \multicolumn{1}{c|}{} & \multicolumn{2}{c|}{$1^{1 \text { a } \text { concretagem }}$} & \multicolumn{2}{c|}{$2^{\underline{a}}$ concretagem } \\
\hline CP & $\begin{array}{c}\text { Força } \\
\text { máxima } \\
(\mathrm{kN})\end{array}$ & $\begin{array}{c}\text { Resistência à tração } \\
(\mathrm{MPa})\end{array}$ & $\begin{array}{c}\text { Força } \\
\text { máxima } \\
(\mathrm{kN})\end{array}$ & $\begin{array}{c}\text { Resistência à tração } \\
(\mathrm{MPa})\end{array}$ \\
\hline $\mathrm{CP} 1$ & 139,1 & 4,42 & 93,7 & 2,98 \\
\hline $\mathrm{CP} 2$ & 73,9 & 2,53 & 142,5 & 4,54 \\
\hline $\mathrm{CP} 3$ & 132,0 & 4,20 & 138,5 & 4,41 \\
\hline & Média & 3,72 & Média & 3,98 \\
\hline
\end{tabular}

\subsubsection{Referente ao aço do perfil da viga}

Foram adquiridos perfis I constituídos por aço ASTM A572 GR 50 (NBR7007 AR350), e realizados ensaios de tração uniaxial em três amostras retiradas da alma 
desses mesmos perfis metálicos. Esses ensaios foram feitos para certificação da qualidade e caracterização das propriedades do material dos perfis. Os ensaios seguiram as recomendações da ABNT NBR ISO 6892-1:2013, cujos detalhe do corpo de prova, esquema de ensaio e respectivos resultados estão apresentados na Figura 3.6 e na Tabela 3.5 .
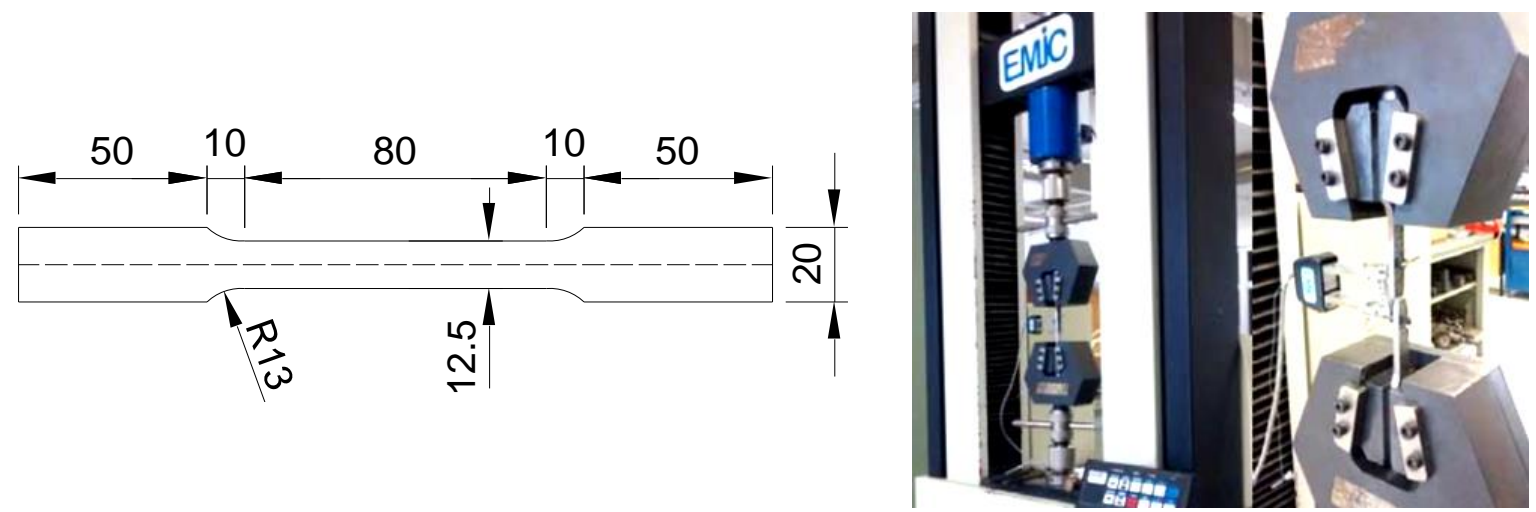

Figura 3.6 - Corpo de prova do aço e ensaio de caracterização

Tabela 3.5 - Resultados propriedades mecânicas

\begin{tabular}{|c|c|c|}
\hline Amostra & $\begin{array}{c}\text { Resistência } \\
\text { última (MPa) }\end{array}$ & $\begin{array}{c}\text { Resistência ao } \\
\text { escoamento } \\
\text { (MPa) }\end{array}$ \\
\hline 1 & 520,3 & 380,2 \\
\hline 2 & 523,8 & 385,3 \\
\hline 3 & 522,7 & 394,2 \\
\hline Média & 522,3 & 386,6 \\
\hline
\end{tabular}

\subsubsection{Referente às barras de aço da armadura}

Os ensaios de tração nas barras das armaduras seguiram as recomendações da ABNT NBR 6892-1:2013. Duas amostras de $100 \mathrm{~cm}$ de comprimento foram usadas na caracterização das armaduras transversais e longitudinais, as quais foram 
ensaiadas em uma máquina de ensaio universal com capacidade de 1500 kN. Os resultados são descritos na Tabela 3.6.

Tabela 3.6 - Determinação da resistência ao escoamento das barras (em MPa)

\begin{tabular}{|c|c|c|}
\hline Amostra & $\Phi 5 \mathrm{~mm}$ & $\Phi 6,3 \mathrm{~mm}$ \\
\hline 1 & 670 & 623 \\
\hline 2 & 692 & 648 \\
\hline Média & 681 & 636 \\
\hline
\end{tabular}

\subsection{Instrumentação}

Neste item será detalhada toda a instrumentação utilizada nesse programa experimental, cujas etapas serão apresentadas em duas partes distintas. Uma primeira etapa mostrando a instrumentação utilizada nos ensaios realizados à temperatura ambiente, bem como uma segunda apresentando aos ensaios realizados em temperatura elevada.

\subsubsection{Ensaios realizados à temperatura ambiente}

Em temperatura ambiente foram realizados ensaios em vigas com flexão a três pontos, cuja condição estática consistia de sistema simplesmente apoiado com força concentrada aplicada no meio do vão igual a $5100 \mathrm{~mm}$.

Além de uma célula de carga para monitoramento, controle e consequente obtenção do valor da força aplicada, também foram utilizados 3 transdutores para fins de controle de deslocamento. Os transdutores 1 e 3 estavam posicionados a $400 \mathrm{~mm}$ de ambos os apoios (extremidades da viga), enquanto o transdutor 2 foi posicionado no meio do vão, conforme ilustrado na Figura 3.7. 


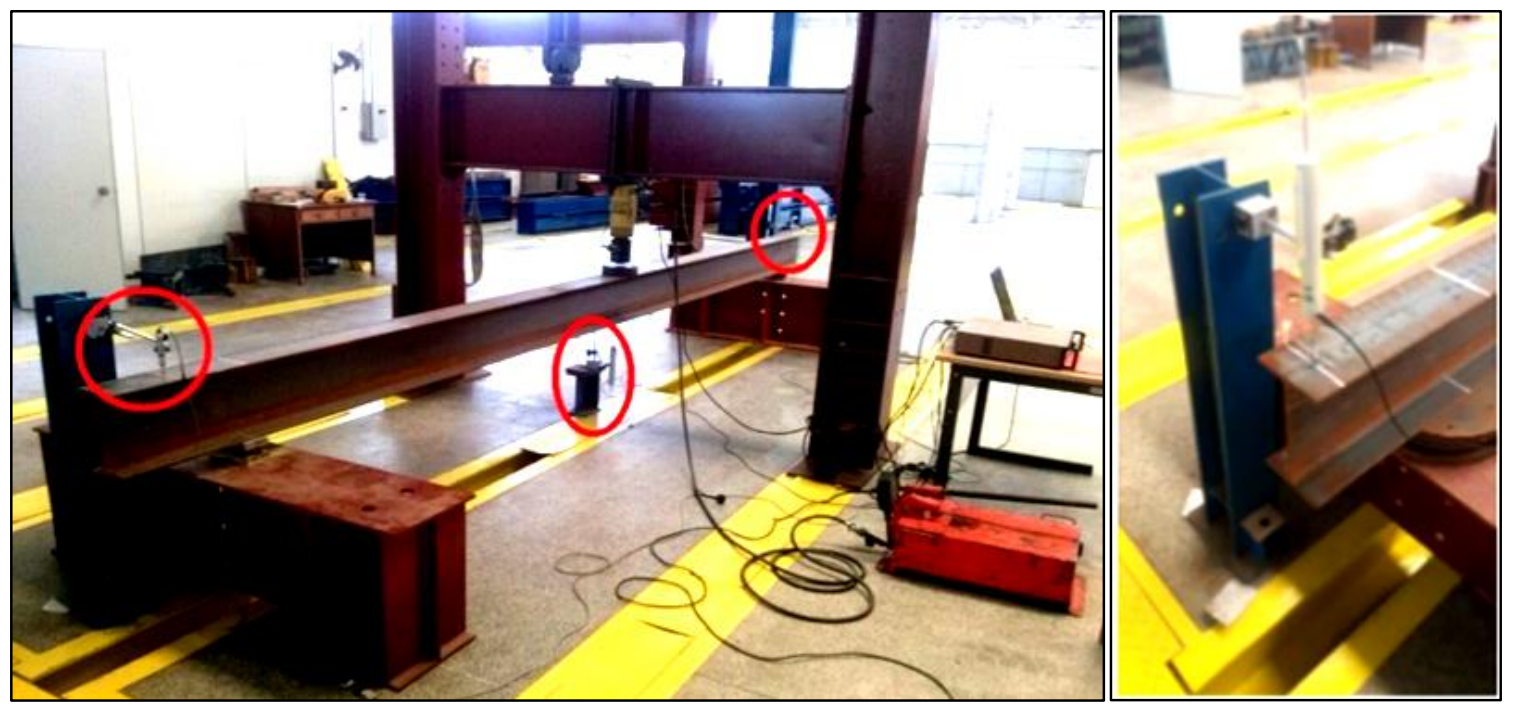

Figura 3.7- Transdutores posicionados em um dos ensaios em temperatura ambiente

\subsubsection{Ensaios em temperatura elevada}

Nos ensaios termoestruturais, as grandezas básicas que foram medidas durante os ensaios são: (1) temperatura, em diversas seções ao longo da viga; (2) deslocamentos em determinados pontos de interesse e (3) força aplicada ao longo do ensaio. A seguir são apresentados os procedimentos e os equipamentos que foram utilizados para medir cada uma das grandezas citadas anteriormente.

\subsubsection{Temperaturas}

As temperaturas ao longo da viga foram medidas por meio de cabos termopares do tipo $\mathrm{K}$ instalados em 3 seções diferentes ao longo da viga, conforme a Figura 3.9. Os termopares do tipo $\mathrm{K}$ tem $2,5 \mathrm{~mm}$ de diâmetro e são formados por fios de Chromel (termoelemento positivo) e Alumel (termoelemento negativo), e são adequados para medir temperaturas continuamente entre $-200^{\circ} \mathrm{C}$ e $1260^{\circ} \mathrm{C}$.

A leitura de temperatura ocorre no ponto onde os dois fios (Chromel e Alumel) estão unidos (em contato). Essa junção foi feita através da soldagem dos fios feita com o equipamento Thermocouple Attachment Unit (TAU), marca STORK, modelo 41757. A outra extremidade do termopar foi ligado a um conector para a ligação ao 
sistema de aquisição de dados do forno. O equipamento TAU e um dos conectores usados podem ser vistos na Figura 3.8.

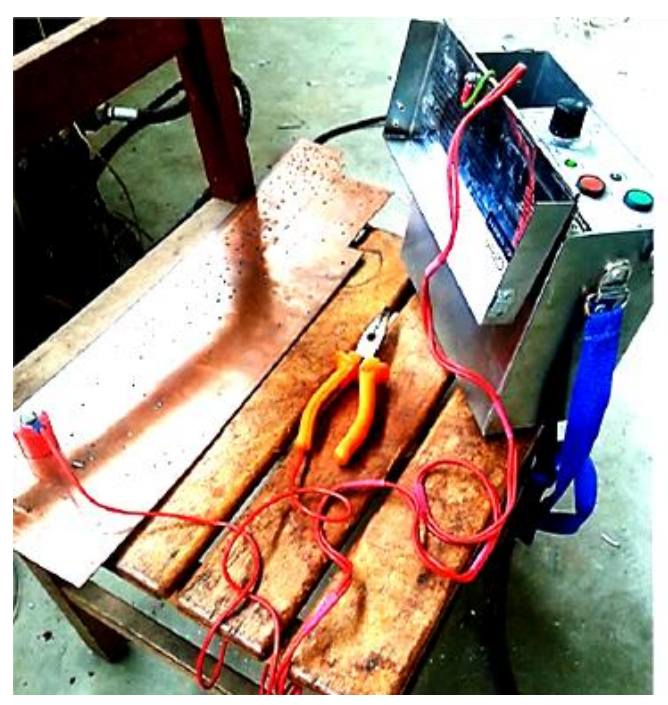

(a)

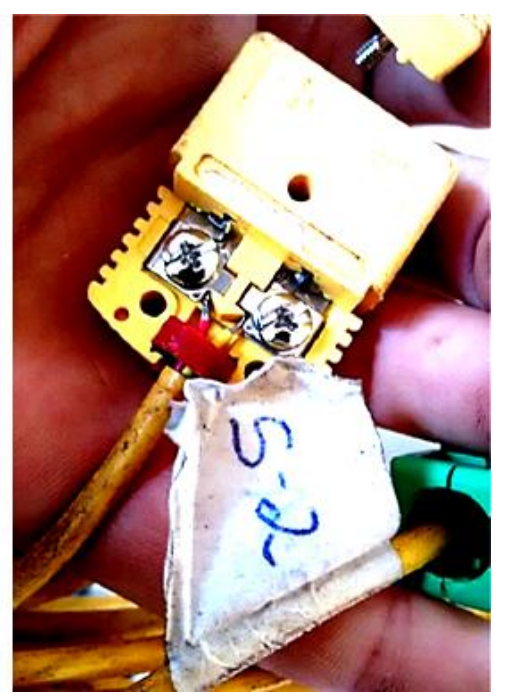

(b)

Figura 3.8 - (a) Equipamento TAU e (b) conectores utilizados

Nas vigas de aço e mistas de aço e concreto os termopares foram instalados conforme a Figura 3.9 em seções das vigas dispostas de forma igual é mostrado na Figura 3.10. Os pontos de leitura foram nomeados Tx.z, onde " $x$ " representa o número da seção ao longo da viga e "z" representa o ponto de leitura. (Exemplo: T1.3 é a temperatura medida no ponto 3 da seção $\$ 1$ ).
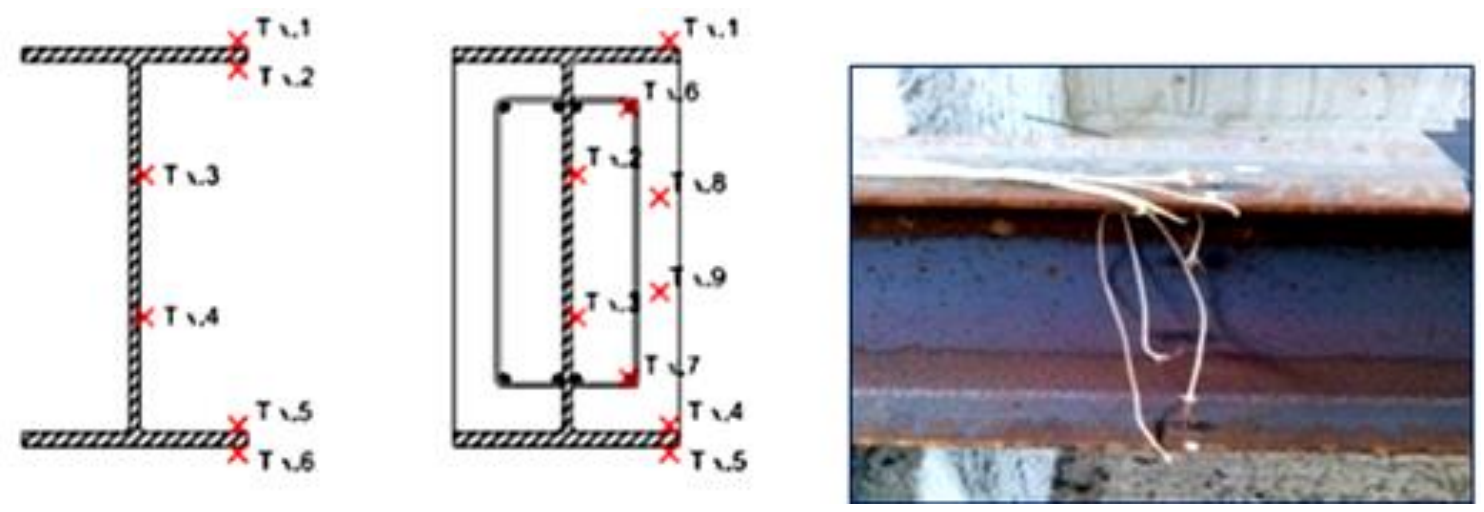

Figura 3.9- Posicionamento dos termopares no perfil das vigas 


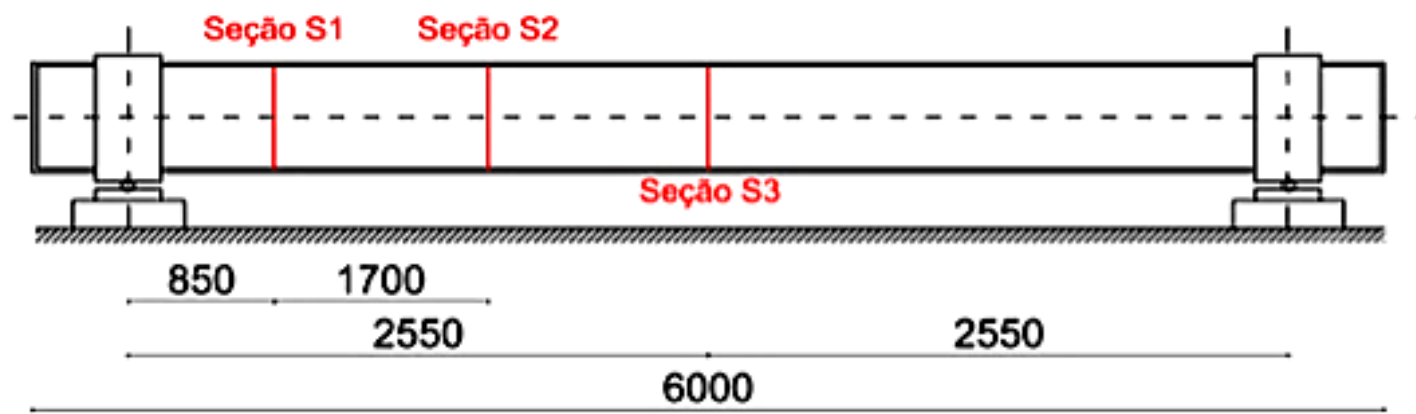

Figura 3.10 - Seções de análise para fins de instrumentação das vigas

Nas vigas puramente metálicas o número de termopares instalados ao longo da seção resultou menor, uma vez que ocorre uma uniformidade maior do aumento da temperatura no perfil comparado as vigas mistas de aço e concreto.

\subsubsection{Monitoramento dos Deslocamentos}

Um dos principais instrumentos de controle para determinar o comportamento estrutural de um elemento em um ensaio termoestrutural se volta aos deslocamentos ocorridos. Para acompanhar o deslocamento que a viga apresentava no meio do seu vão livre foram utilizados dois transdutores de fio marca VISHAY, modelo CDS - 50, com curso de $127 \mathrm{~cm}$. Nesses transdutores foi acoplado um cabo termopar que foi amarrado a viga no interior do forno. Os transdutores podem ser visualizados na Figura 3.11.

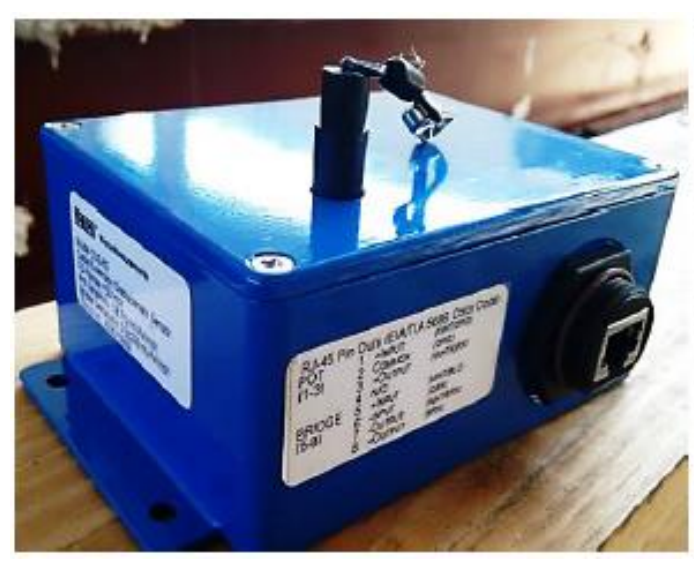

(a)

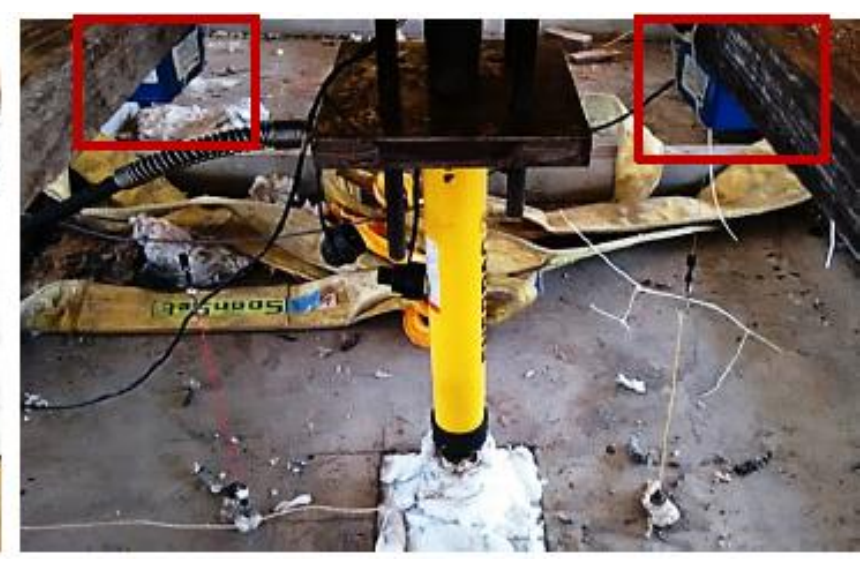

(b)

Figura 3.11 - (a)Transdutor de fio e (b) Respectivo posicionamento 


\subsubsection{Aplicação das Forças}

Nos ensaios termoestruturais foi considerada a ocorrência de força concentrada aplicada no meio do vão por meio da utilização de um cilindro hidráulico marca ENERPAC, modelo RC 1012, com capacidade máxima de $10 \mathrm{kN}$ e curso de $304 \mathrm{~mm}$. Ao cilindro foi adicionado um prolongador de $500 \mathrm{~mm}$, e este foi revestido com manta cerâmica para poder ser utilizado no interior do forno. A Figura 3.12 mostra o cilindro hidráulico e o prolongador protegido com manta cerâmica.

Uma célula de carga foi utilizada como transdutor de medição da força aplicada, como mostra a Figura 3.13, a qual foi posicionada na parte superior do cilindro hidráulico. As leituras das forças foram registradas em um sistema de aquisição de dados tipo SYSTEM 5000.

\subsection{Resultados e discussões referentes aos ensaios realizados}

No que se segue, serão apresentados resultados e discussões para os ensaios realizados no programa experimental. Primeiro serão discutidos os ensaios em temperatura ambiente e em seguida os ensaios à temperatura elevada. É importante destacar que os resultados encontrados nos ensaios em temperatura ambiente serviram de base para os ensaios em temperatura elevada (na definição dos fatores de carga aplicados). 

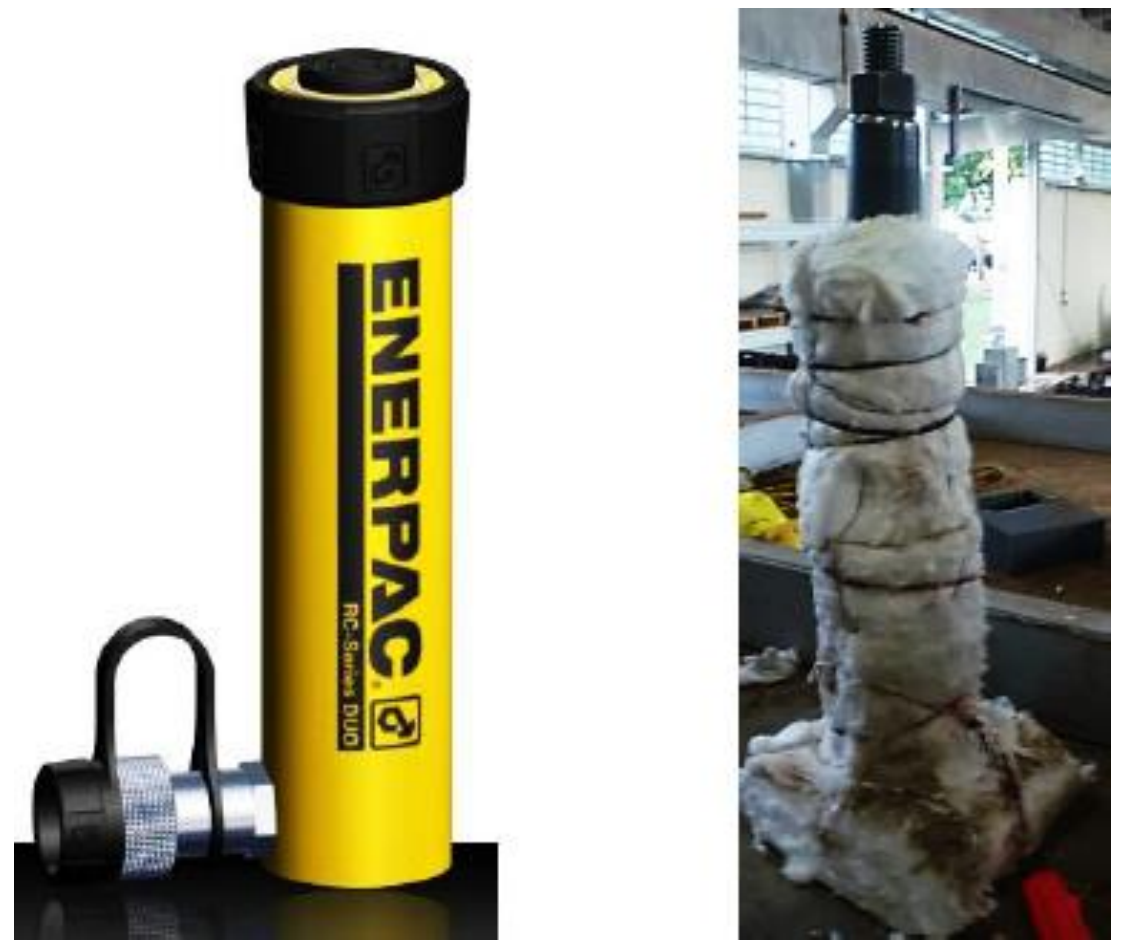

Figura 3.12 - Cilindro hidráulico e prolongador protegido com manta cerâmica

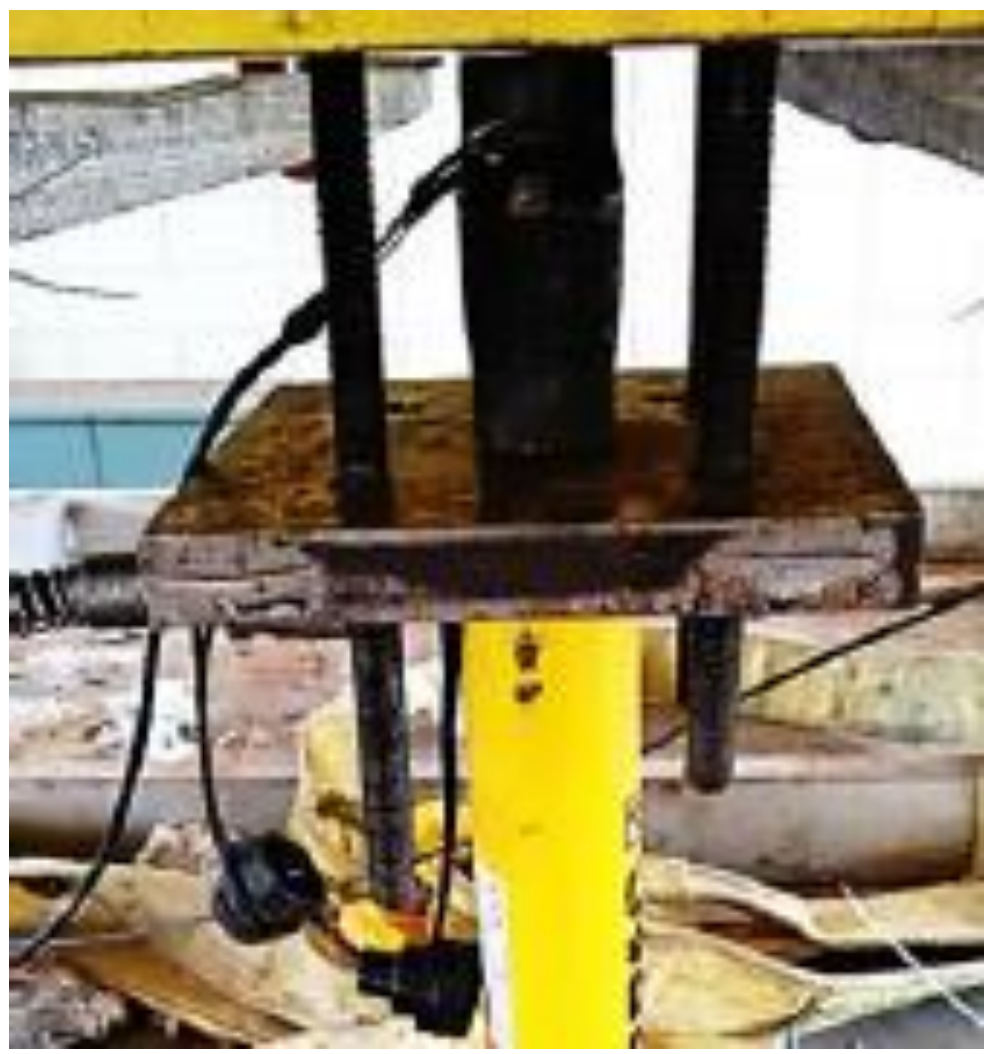

Figura 3.13 - Célula de carga utilizada para aplicação da força na viga 


\subsubsection{Resultados referentes aos ensaios à temperatura ambiente}

Os ensaios realizados consideraram flexão a três pontos, uma vez que as vigas estavam em condição estática simplesmente apoiada com força concentrada aplicada no meio do vão. Após a instrumentação dos elementos a serem ensaiados, a carga foi aplicada no meio do vão livre e aumentada até o momento de ruptura do elemento. Os valores da carga e dos deslocamentos nos transdutores 1 (à direita da viga), 2 (no centro da viga) e 3 (à esquerda da viga) eram gravados, o que permitiu a construção de gráficos que relacionassem essas grandezas.

A seguir, serão apresentados os resultados dos dois tipos de vigas consideradas no programa experimental, no caso, viga de aço isolada e viga mista de aço e concreto parcialmente revestida.

\subsubsection{Viga de aço isolada}

O elemento metálico atingiu sua capacidade resistente quando a carga atingiu $123 \mathrm{kN}$. Nesse instante, o deslocamento resultou igual a $54,1 \mathrm{~mm}$ no centro do vão, como mostra a Figura 3.14. Vale notar que quando a carga atinge valores próximos a $110 \mathrm{kN}$, o material entra em regime plástico, no qual o deslocamento continua a crescer mesmo sem aumento significativo da força aplicada.

Quando a força atinge $123 \mathrm{kN}$, a viga atinge a sua capacidade resistente e sua deformação é diminuída até o valor residual de $19 \mathrm{~mm}$, quando então não consegue mais voltar às condições iniciais. A Figura 3.15 representa os deslocamentos nos transdutores 1, 2 e 3 em função da carga aplicada. Os deslocamentos obtidos com fator de carga igual a $30 \%$ (utilizado nos ensaios em temperatura elevada) estão detalhados na Tabela 3.7. 


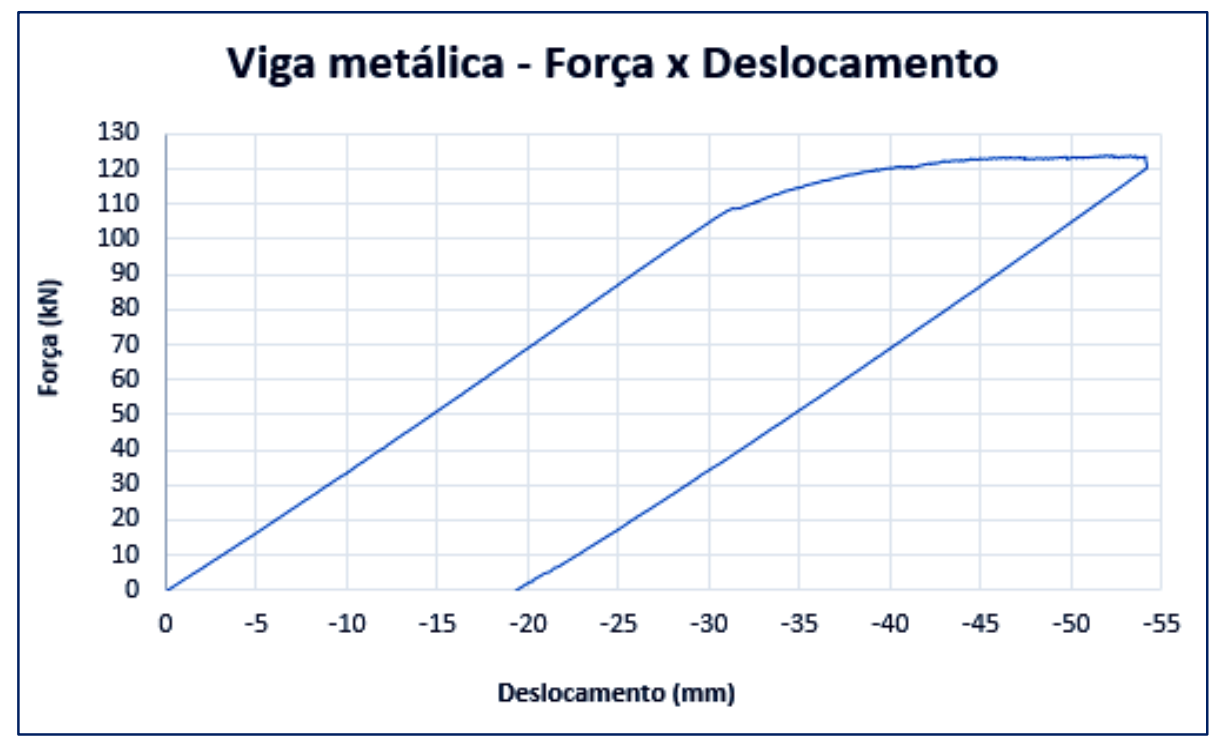

Figura 3.14 - Gráfico referente à força aplicada em função do deslocamento no centro do vão da viga metálica, ensaiada à temperatura ambiente.

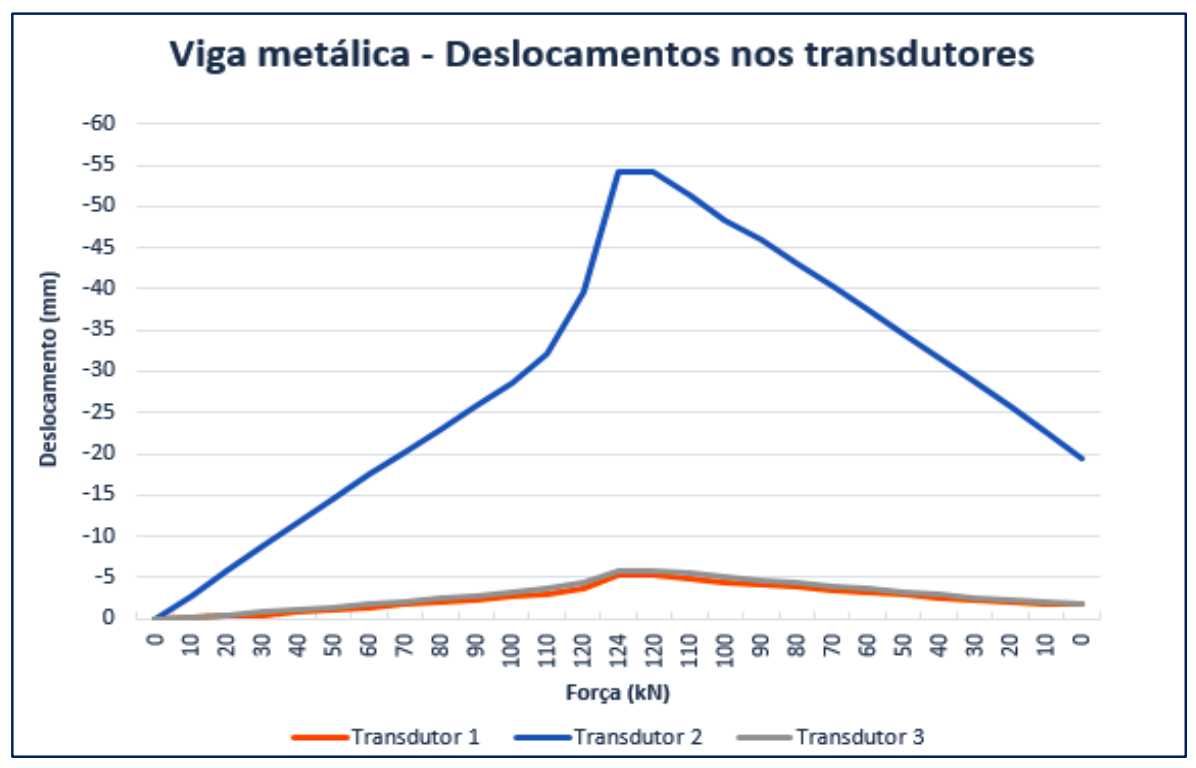

Figura 3.15 - Gráfico referente aos deslocamentos nos transdutores 1, 2 e 3 em função da carga aplicada na viga metálica, ensaiada à temperatura ambiente. 
Tabela 3.7-Deslocamento nos transdutores 1, 2 e 3 quando aplicado um fator de carga de $30 \%$ na viga metálica, ensaiada em temperatura ambiente

\begin{tabular}{|c|c|c|c|c|}
\hline \multirow{2}{*}{ Fator de carga } & \multirow{2}{*}{ Força $(\mathrm{kN})$} & \multicolumn{3}{|c|}{ Deslocamentos (mm) } \\
\cline { 3 - 5 } & & Transdutor 1 & Transdutor 2 & Transdutor 3 \\
\hline $30 \%$ & 37,65 & 0,7 & 11,1 & 1,0 \\
\hline
\end{tabular}

\subsubsection{Viga mista de aço e concreto parcialmente revestida}

Com relação à viga mista de aço e concreto, durante o ensaio foi possível identificar que a mesma atingiu sua capacidade resistente quando a força aplicada estava próxima dos $164 \mathrm{kN}$. Nesse instante, o deslocamento resultou igual a 71,1 mm no centro do vão, como mostra a figura 3.16.

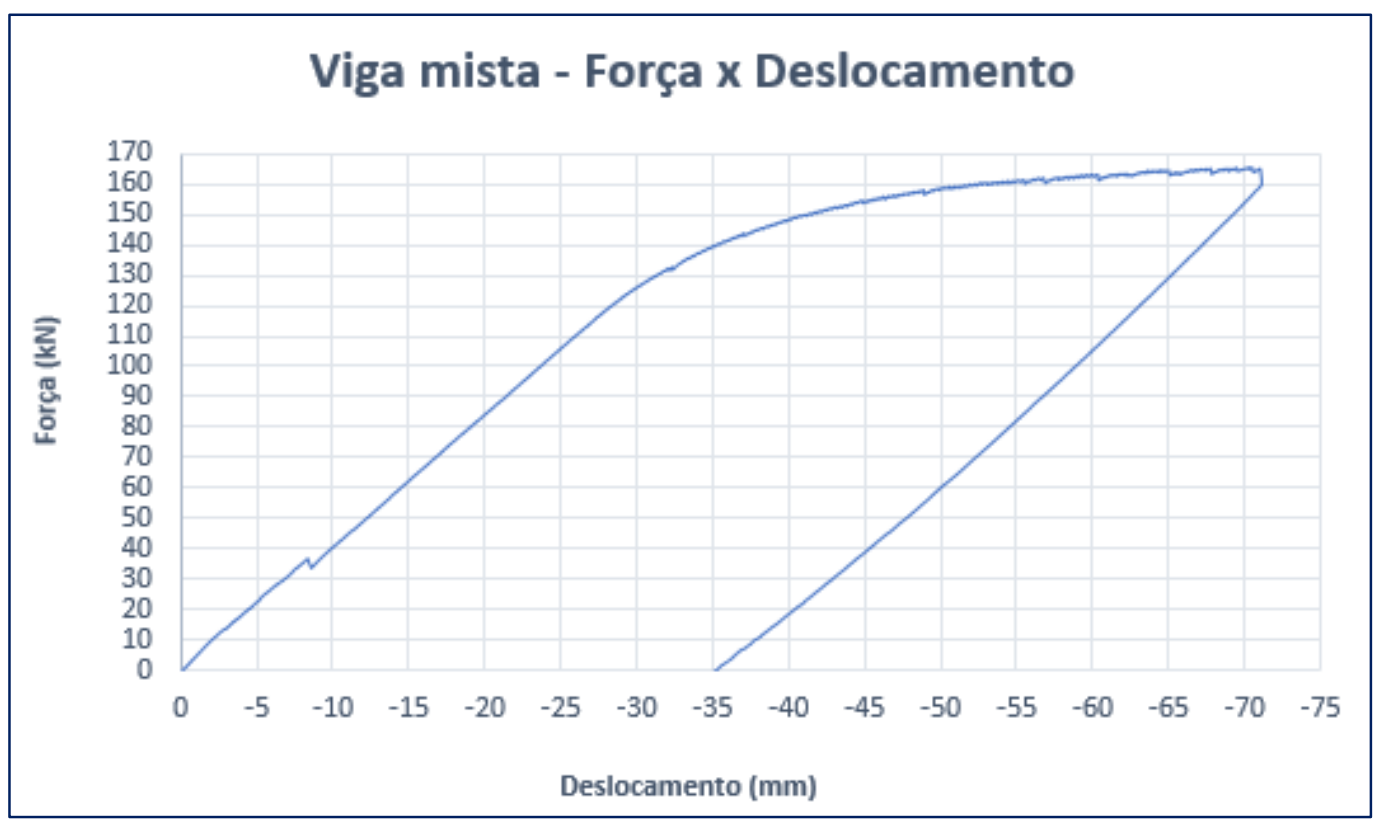

Figura 3.16 - Gráfico referente à força aplicada em função do deslocamento no centro do vão da viga mista de aço e concreto, ensaiada à temperatura ambiente. 
Nota-se que quando a carga atinge valores próximos a 140 kN, o material entra em regime inelástico, no qual o deslocamento continua a crescer mesmo sem aumento significativo da força aplicada. Quando esta mesma força atinge $164 \mathrm{kN}$, a viga atinge sua capacidade resistente e sua deformação é diminuída até o valor residual igual a $35 \mathrm{~mm}$, situação em que não se consegue mais voltar às condições iniciais.

A Figura 3.17 traz informações que representam os deslocamentos nos transdutores 1, 2 e 3 em função da carga aplicada. Os deslocamentos obtidos nos fatores de carga igual a $30 \%$ e a $45 \%$, os quais serão de interesse quando da realização dos ensaios em temperatura elevada, estão detalhados na Tabela 3.8.

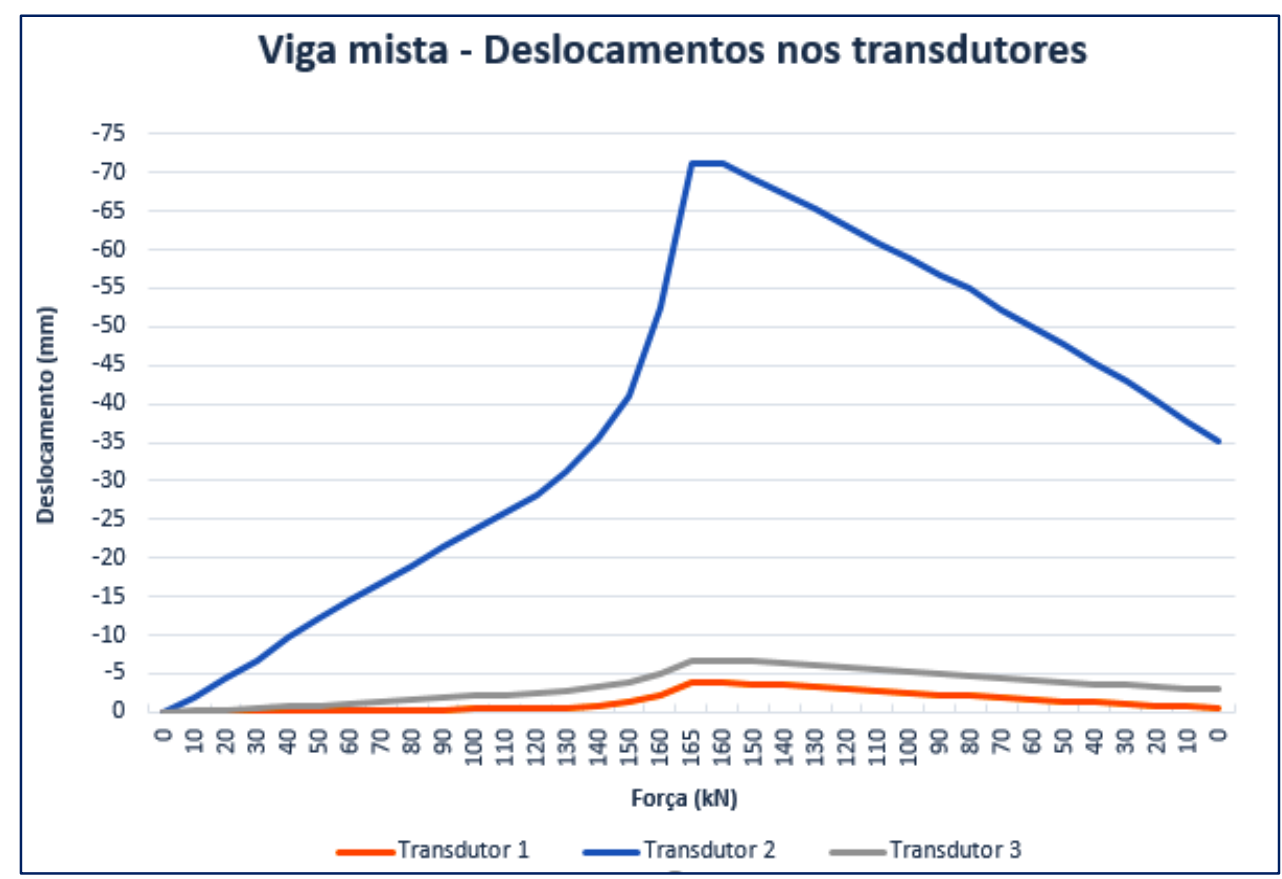

Figura 3.17 - Gráfico dos deslocamentos nos transdutores 1, 2 e 3 em função da carga aplicada na viga mista de aço e concreto, ensaiada em temperatura ambiente 
Tabela 3.8 - Deslocamento nos transdutores 1, 2 e 3 quando aplicados os fatores de carga de $30 \%$ e de $45 \%$ na viga mista de aço e concreto, ensaiada à temperatura ambiente

\begin{tabular}{|c|c|c|c|c|}
\hline \multirow{2}{*}{ Fator de carga } & \multirow{2}{*}{ Força (kN) } & \multicolumn{3}{|c|}{ Deslocamentos (mm) } \\
\cline { 3 - 5 } & & Transdutor 1 & Transdutor 2 & Transdutor 3 \\
\hline $30 \%$ & 48,24 & 0,4 & 11,8 & 0,9 \\
\hline $45 \%$ & 72,36 & 0,7 & 17,3 & 1,4 \\
\hline
\end{tabular}

\subsubsection{Resultados referentes aos ensaios em Temperatura Elevada}

Quando da realização dos ensaios em temperaturas elevadas, vale inicialmente destacar que, além de toda a instrumentação citada nos itens anteriores voltadas aos ensaios à temperatura ambiente, também se fez necessária a confecção de fechamentos laterais para o forno, como pode ser observado na Figura 3.18. Tais fechamentos eram constituídos de madeira e manta cerâmica, com vistas a promover $o$ isolamento do interior do forno com o ambiente externo a esse mesmo equipamento utilizado.

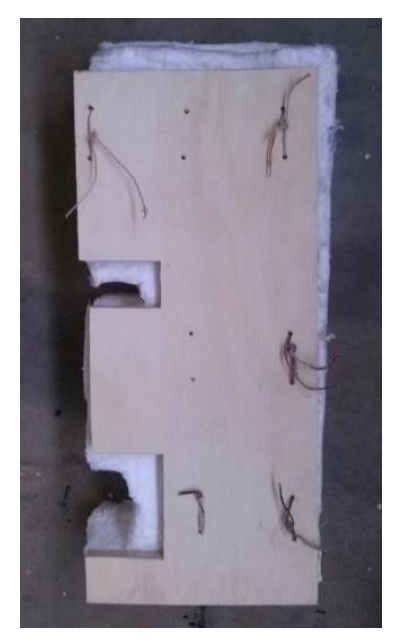

Figura 3.18 - Fechamentos de madeira utilizados nas aberturas laterais do forno 
Finalizada a preparação das vigas de aço e mistas de aço e concreto, foram realizados os ensaios em temperatura elevada para a verificação das mesmas, tanto em relação ao seu comportamento estrutural em situação de incêndio, quanto com relação à influência do revestimento de concreto no perfil metálico. Basicamente, tais ensaios foram constituídos de ação térmica em conjunto com ação mecânica.

Primeiramente, era aplicada a carga mecânica, com os valores apresentados nos ensaios à temperatura ambiente, considerando fator de carga igual a 30\% para viga metálica, bem como fatores de carga iguais a 30\% e $45 \%$ para as vigas mistas de aço e concreto. Em seguida, o forno era ativado, realizando o aquecimento até o instante em que fosse observado deslocamento excessivo nos elementos. Devido à penalização das propriedades térmicas e mecânicas dos materiais, a força aplicada passava a resultar gradualmente reduzida, sendo necessário, durante a fase de aquecimento, que a mesma fosse compensada para manutenção do nível de carga estipulado.

A Figura 3.19 ilustra um esquema da montagem dos ensaios de flexão a três pontos no interior do forno horizontal. A vedação da parte superior foi realizada com a instalação da tampa do forno, na qual foram realizadas furações para a passagem do prolongador acoplado ao cilindro hidráulico e dos cabos conectados aos transdutores de deslocamento.

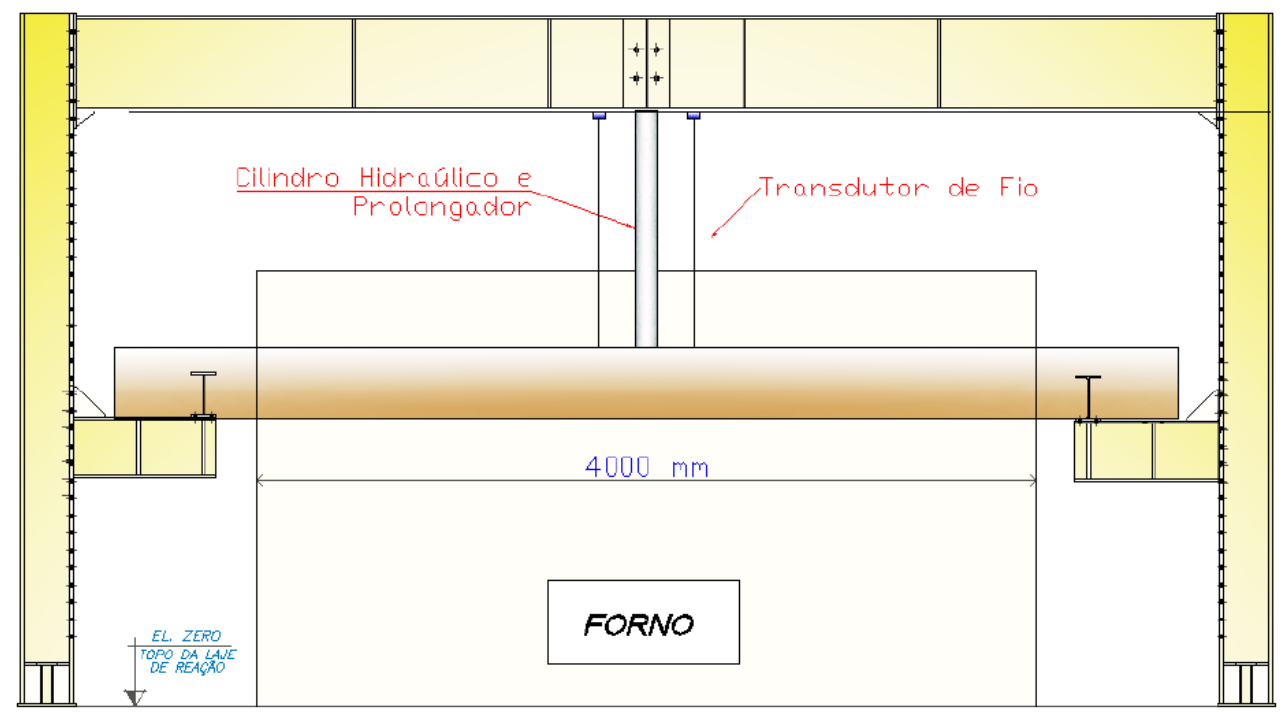

Figura 3.19 - Esquema do ensaio com aplicação de carga 
Outro ponto importante a ser ressaltado se refere ao destaque para a face superior das vigas de aço, as quais foram revestidas com manta cerâmica para garantir nessa mesma face 0 isolamento térmico e proteção dos termopares necessários para a realização dos ensaios, como mostra a figura 3.20. As demais faces (face inferior e faces laterais) ficaram expostas ao fogo.

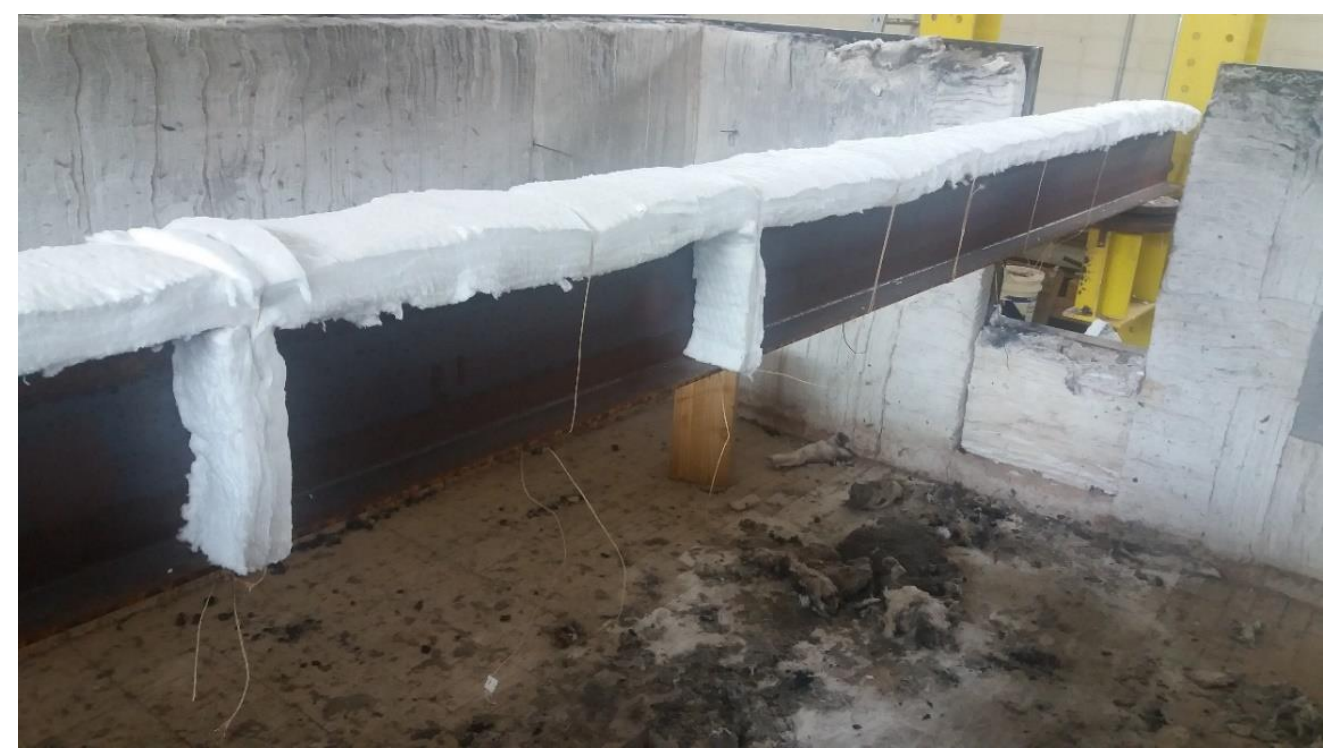

Figura 3.20 - Isolamento térmico imposto à face superior da viga de aço

\subsubsection{Forno horizontal a gás}

Os ensaios em temperaturas elevadas foram realizados em um forno horizontal, com dimensões internas de $3 \mathrm{~m} \times 4 \mathrm{~m} \times 1,5 \mathrm{~m}$, o qual se encontra alocado nas dependências do Laboratório de Estruturas do Departamento de Engenharia de Estruturas da USP em São Carlos. Trata-se de um forno que permite a realização de ensaios de elementos estruturais dos tipos lajes, vigas e similares, em temperaturas elevadas, com funcionamento a gás, no qual a temperatura máxima que pode atingir níveis da ordem de $1260^{\circ} \mathrm{C}$.

$\mathrm{Na}$ Figura 3.21 é apresentado o interior desse mesmo forno, com pisos de tijolos de alta resistência mecânica e térmica em seu piso, bem como paredes revestidas com manta de fibras cerâmicas em suas laterais. 

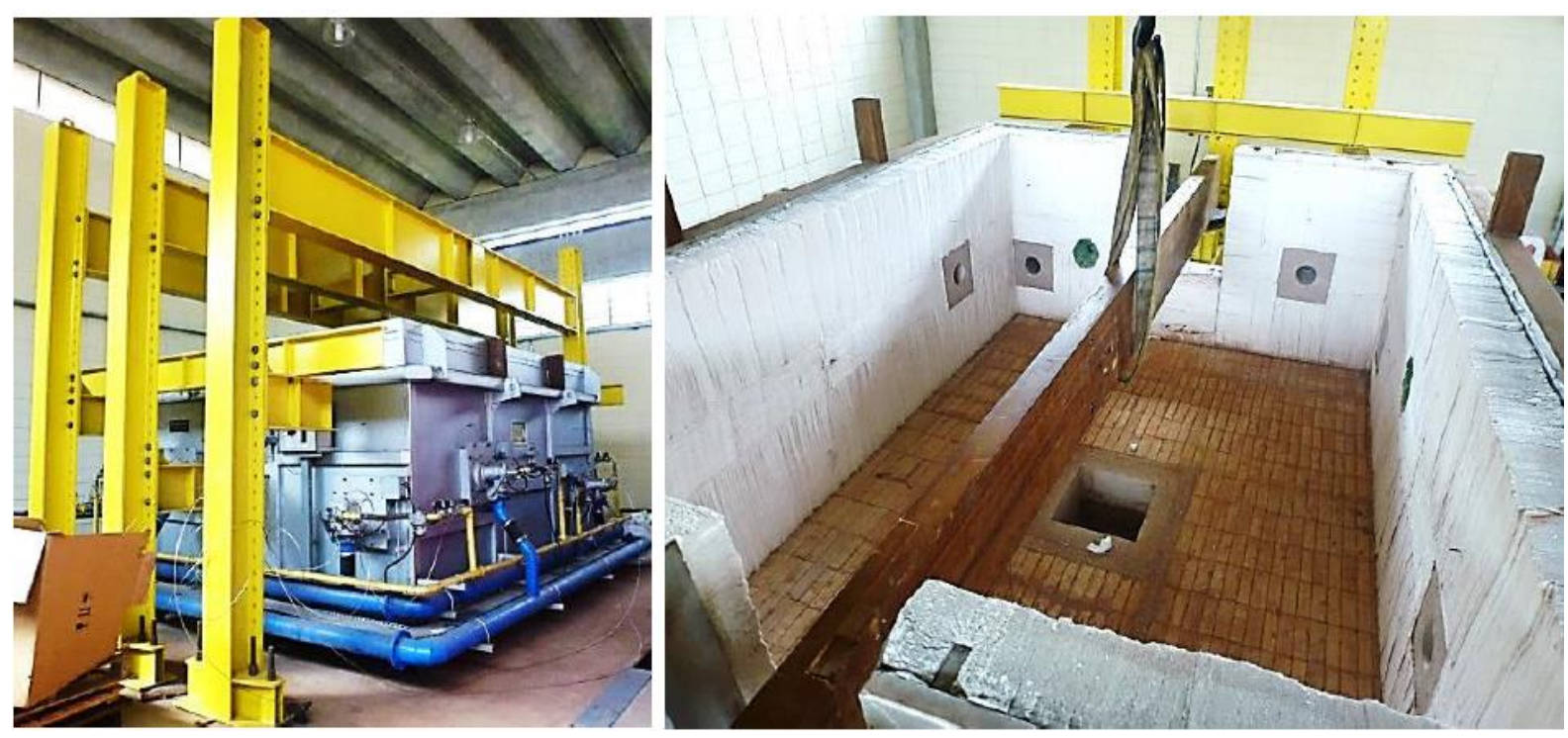

Figura 3.21 - Forno horizontal a gás alocado nas dependências do Laboratório de Engenharia de Estruturas da EESC/USP

O forno possui oito queimadores com potência total igual a $3600 \mathrm{~kW}$ que podem ser ligados e desligados individualmente. Esses queimadores são programados para fazer o aquecimento do forno de acordo com qualquer curva de aquecimento de interesse, inclusive a curva de incêndio-padrão, a qual foi aqui utilizada, considerando o acionamento ou não automaticamente desses mesmos queimadores durante o ensaio para garantir a manutenção dos níveis de temperatura dentro das tolerâncias estabelecidas para a validação da curva de incêndio-padrão.

A curva de incêndio-padrão adotada nesse programa experimental foi definida com base naquela proposta pela ISO 834-1:1999. Essa curva pode ser obtida e controlada pela Equação 3.1, para a qual valem $\mathrm{T}$ como sendo a temperatura média do forno $\left({ }^{\circ} \mathrm{C}\right)$, bem como $t$ como sendo o tempo em minutos.

$$
\mathrm{T}=345 \cdot \log (8 t+1)+20
$$

Após o início do aquecimento, a ISO 834-1:1999 traz algumas recomendações a respeito dos critérios de parada que devem ser considerados para avaliar a resistência ao fogo de elementos expostos ao incêndio-padrão. Os critérios se baseiam em: capacidade resistente do elemento, integridade (capacidade do elemento em manter sua função de isolar o fogo) e isolamento (verificar se o calor que 
passa por condução da superfície exposta não é maior que os limites lá estabelecidos).

Como as vigas ensaiadas estavam inseridas completamente no forno, sendo a face não exposta representada por uma face protegida contra o fogo (manta cerâmica), nos ensaios do programa experimental em questão só foi utilizado o critério de capacidade resistente do elemento, o qual para peças fletidas se baseia no deslocamento limite e na taxa de deslocamento limite, dados pelas Equações 3.2 e 3.3 que seguem:

\section{Deslocamento limite:}

$$
D=\frac{L^{2}}{400 \cdot d}
$$

\section{Taxa de deslocamento limite:}

$$
\frac{d D}{d t}=\frac{L^{2}}{9000 \cdot d}
$$

Nas Equações 3.2 e 3.3, d é a distância entre as fibras extremas, comprimida e tracionada da seção transversal, e L é o vão da viga. Vale ressaltar que o critério de taxa de deslocamento só pode ser aplicado quando o deslocamento do meio do vão for maior que $\mathrm{L} / 30$.

\subsubsection{Viga metálica}

No ensaio da viga metálica à temperatura ambiente foi utilizado o fator de carga igual a 30\% em relação ao valor obtido no ensaio em temperatura ambiente, ou seja, $37,65 \mathrm{kN}$. O ensaio com a viga metálica foi finalizado após 7 minutos de aquecimento, quando foi observado um deslocamento excessivo, da ordem de $92 \mathrm{~mm}$ no centro do vão e rotação excessiva nos apoios, conforme na Figura 3.22. 

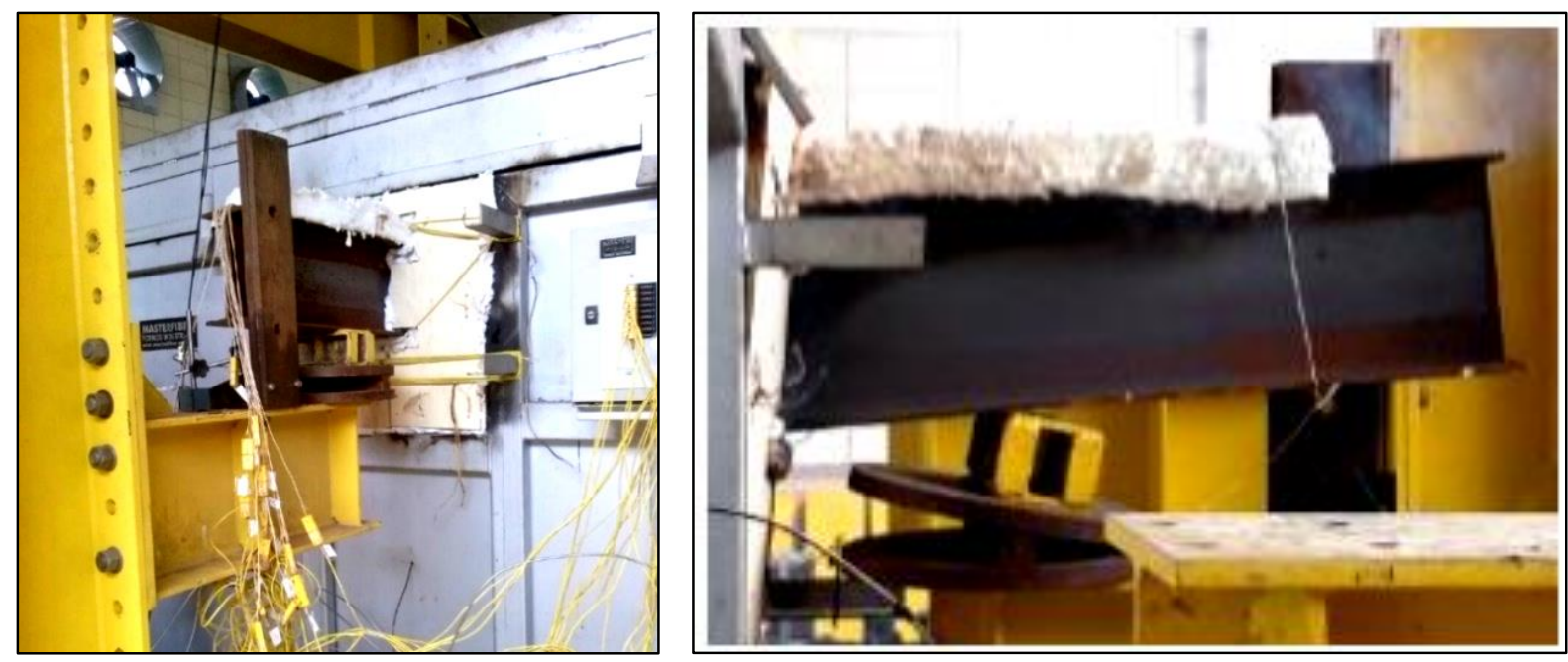

Figura 3.22 - Fechamento lateral do forno e rotação excessiva em um dos apoios

O modelo apresentou uma taxa de deslocamento médio de aproximadamente $13,1 \mathrm{~mm} / \mathrm{min}$, totalizando os $92 \mathrm{~mm}$ ao final dos 7 minutos de ensaio. Neste instante, não era mais possível compensar o carregamento perdido, devido à elevada taxa de deslocamento da viga, o que já caracterizava a perda de sua capacidade resistente.

Na Figura 3.23 são apresentados os deslocamentos medidos no meio do vão (média entre ambos os transdutores 1 e 2), o deslocamento medido na extremidade da viga (transdutor 3), bem como a força aplicada durante todo o ensaio, em função do tempo e da temperatura média da seção central. Vale ressaltar que, ao final do ensaio, o deslocamento continuava a crescer de forma assintótica, apesar do gradual alívio do carregamento mecânico.

$\mathrm{Na}$ figura 3.24 são apresentadas as medidas de temperatura em cada ponto das seções S1 e S2, em função do tempo de ensaio. Durante todo o ensaio, a mesa inferior (Tx.5 e Tx.6) e a alma (Tx.3 e Tx.4) apresentaram temperaturas semelhantes entre si, ambas maiores que as temperaturas na mesa superior (Tx.1 e Tx.2). 
a)

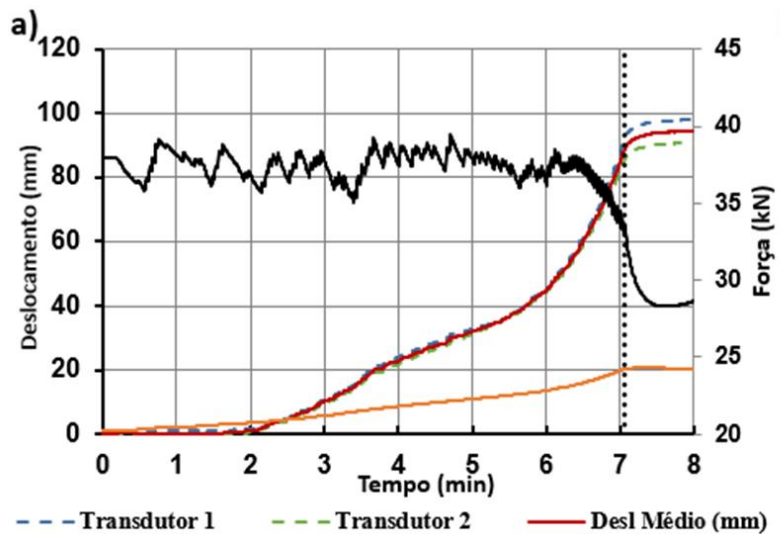

b)

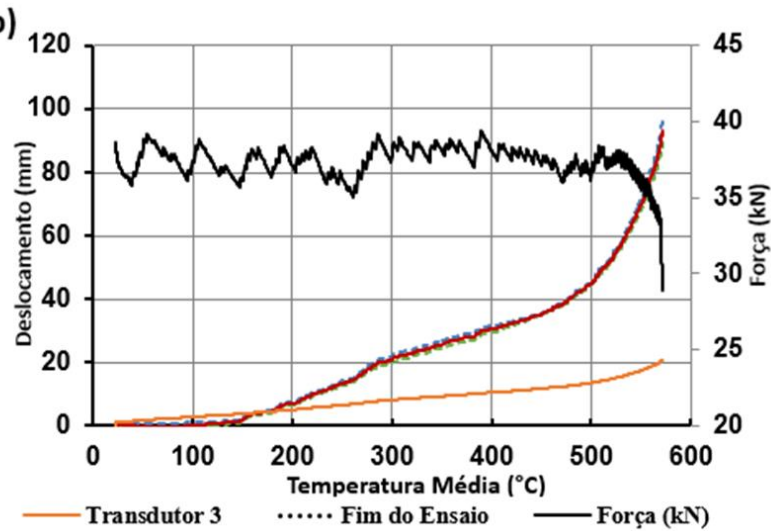

Figura 3.23- Comportamento termoestrutural da viga metálica em função de: (a) tempo do ensaio e (b) temperatura média do perfil metálico na seção central
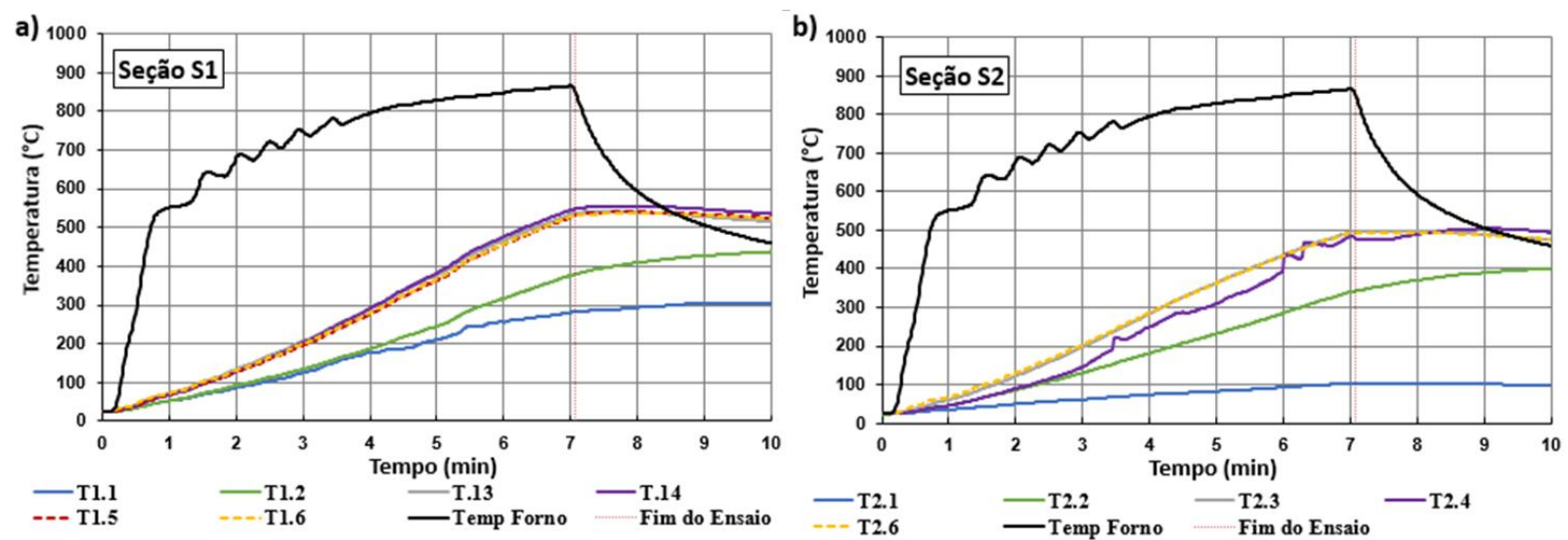

Figura 3.24 - Temperaturas medidas nas seções S1 e S2 durante o ensaio da viga metálica sem revestimento

Tal aspecto se evidenciou uma vez que a face de cima da viga estava protegida com manta cerâmica. Vale destacar a eficiência dessa proteção, uma vez que, mesmo possuindo apenas $9,1 \mathrm{~mm}$ de espessura, a mesa superior apresentou temperaturas inferiores a $400^{\circ} \mathrm{C}$ ao final do ensaio. Já a mesa inferior e a alma apresentaram temperaturas próximas a $550^{\circ} \mathrm{C}$. Vale ressaltar que em temperaturas da ordem de $400^{\circ} \mathrm{C}$ o aço já começa a perder suas propriedades estruturais.

Neste primeiro ensaio com elemento metálico, foi observada rotação excessiva nos apoios, situação que pode ser crítica ao revestimento lateral do forno. Então, por questões de segurança, a equipe responsável pelos ensaios e pelo equipamento 
estipulou que o ensaio com o elemento misto ocorreria até que se observasse um deslocamento de $50 \mathrm{~mm}$ no centro do vão.

\subsubsection{Viga mista de aço e concreto parcialmente revestida - Ensaio I}

O primeiro ensaio com viga mista de aço e concreto, considerando fator de carga igual a $30 \%$, foi realizado em aproximadamente 30 minutos de aquecimento, no qual foi possível observar um comportamento predominantemente dúctil do elemento. A taxa de deslocamento médio no centro da viga resultou igual a $1,7 \mathrm{~mm} / \mathrm{min}$, muito menor se comparado aos resultados obtidos para a viga metálica, totalizando $50 \mathrm{~mm}$ quando o ensaio foi finalizado. Isso é explicado pelas diferentes taxas de aquecimento que cada parte do perfil metálico estará submetida.

Na Figura 3.25 são apresentados os deslocamentos medidos no meio do vão (média entre os transdutores 1 e 2), o deslocamento medido na extremidade da viga (transdutor 3) e a força aplicada durante todo o ensaio, em função do tempo e da temperatura média da seção central. Vale destacar uma menor taxa de deslocamento favorece a aplicação de níveis de força mais elevados, pois se torna mais fácil mantêla constante.
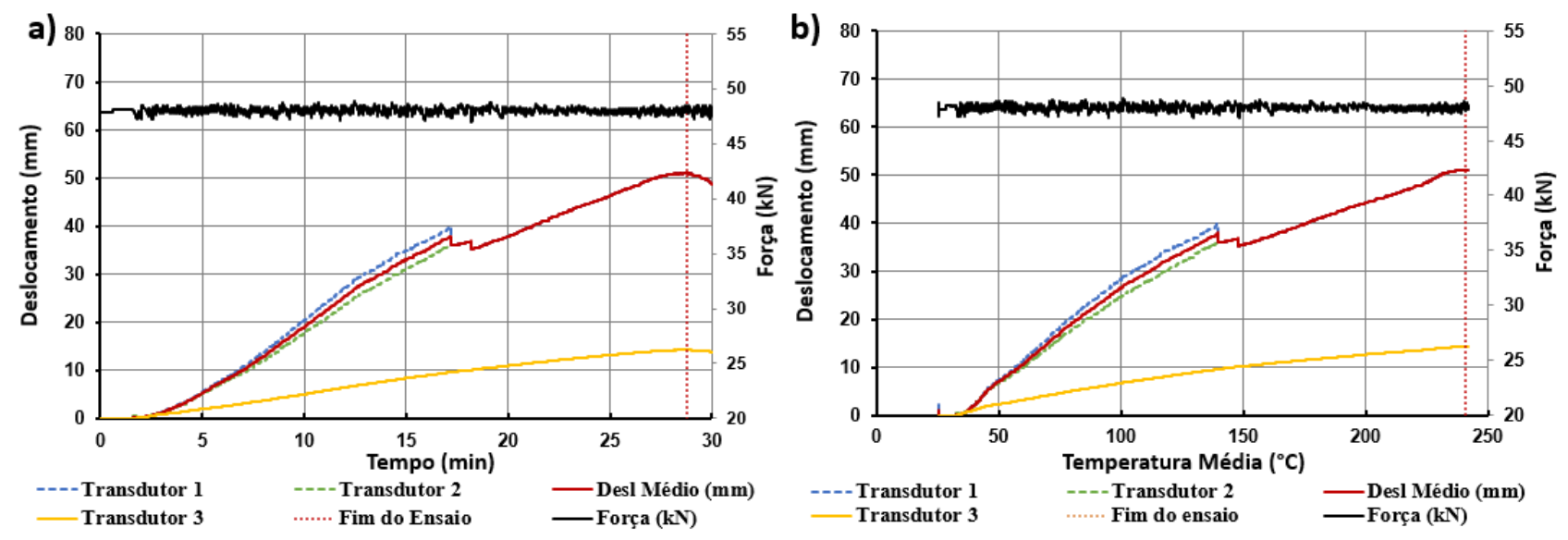

Figura 3.25 - Comportamento termoestrutural da viga mista em função de: (a) tempo do ensaio e (b) temperatura média do perfil metálico na seção central 
Ainda com relação à figura 3.25, pode-se perceber que aos 17 minutos houve descontinuidade na linha do deslocamento médio, aspecto que ocorreu devido a um lascamento do concreto nas regiões próximas ao centro da viga, o qual foi responsável por romper o cabo de um dos transdutores. A partir desse instante, o deslocamento é monitorado pelos valores do transdutor restante.

Outra colocação importante é que, observando o gráfico da figura 3.25b, notase que o ensaio finalizou quando a temperatura média na seção central resultava igual a $270^{\circ} \mathrm{C}$. Nesta mesma temperatura, a viga havia se deslocado apenas $17 \mathrm{~mm}$ segundo a vertical. Porém, como comentado anteriormente, a diferença no deslocamento se dá pelas diferentes taxas de aquecimento do perfil. Comparando a Figura 3.26 com a Figura 3.24, percebe-se que a viga metálica se aquece muito mais rapidamente.
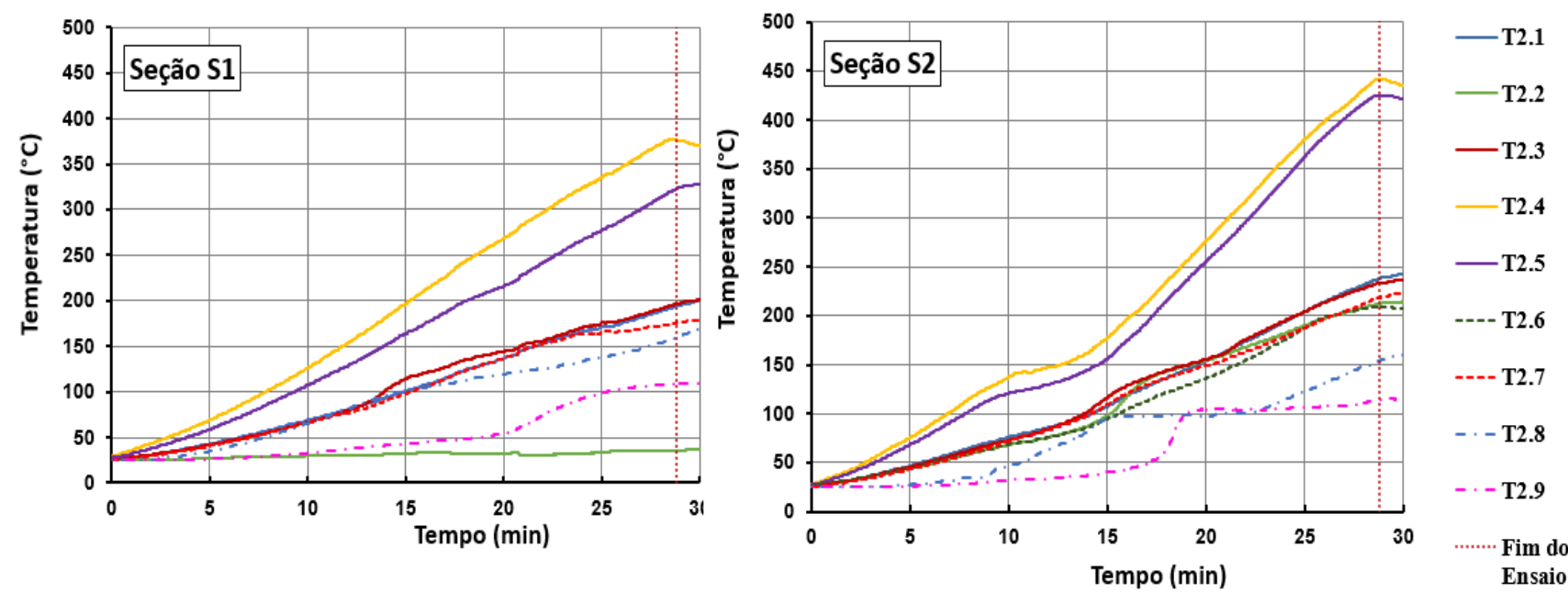

Figura 3.26 - Temperaturas medidas nas seções S1 e S2 durante o ensaio da viga mista de aço e concreto parcialmente revestida

Vale notar que o ponto T1.2 (seção S1) foi considerando como descartado para fins de análise uma vez que, durante o ensaio, a leitura da temperatura não foi realizada corretamente.

Apesar disso, analisando os demais valores encontrados, pode-se verificar que a mesa inferior (Tx.4 e Tx.5) do perfil apresentou as maiores temperaturas, de $300^{\circ} \mathrm{C}$ a $400^{\circ} \mathrm{C}$, enquanto a mesa superior (Tx.1), a alma (Tx.2 e Tx.3) e as armaduras (Tx.6 e Tx.7) finalizaram o ensaio com níveis de temperaturas mais baixas, da ordem de 
$200^{\circ} \mathrm{C}$, ou seja, sem sofrer deterioração das propriedades mecânicas. Já a temperatura no concreto (Tx.8 e Tx.9) ficou próxima dos $150^{\circ} \mathrm{C}$.

Tais resultados comprovam o efeito benéfico do revestimento de concreto ao perfil metálico, protegendo os componentes internos da elevada temperatura, os quais acabam por ter sua capacidade resistente menos afetada.

\subsubsection{Viga mista de aço e concreto parcialmente revestida - Ensaio II}

Devido ao rompimento do cabo de um dos transdutores no primeiro ensaio citado em 3.6.2.3, no segundo ensaio com viga mista de aço e concreto em temperatura elevada também foi utilizado o fator de carga de $30 \%$, visando uma maior precisão nos resultados obtidos.

Esse mesmo ensaio apresentou duração aproximada de 28 minutos, momento no qual se observou rotação excessiva nos apoios da viga e, portanto, a equipe envolvida optou por interromper o ensaio. A taxa de deslocamento médio no centro do vão foi de aproximadamente $1,55 \mathrm{~mm} / \mathrm{min}$, totalizando cerca de $43 \mathrm{~mm}$ no final do ensaio, valores bem próximos aos encontrados no primeiro ensaio de viga mista em situação de incêndio.

Os deslocamentos medidos no centro do vão (média entre os transdutores $1 \mathrm{e}$ 2), o deslocamento medido na extremidade da viga (transdutor 3) e a força aplicada durante todo o ensaio, em função do tempo e da temperatura média da seção central, são apresentados na Figura 3.27 que segue. 


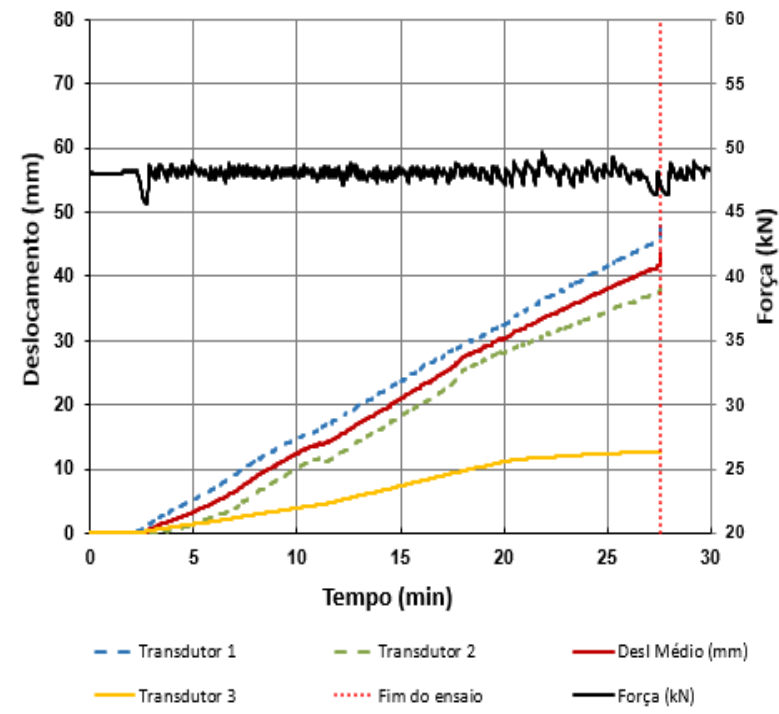

(a)

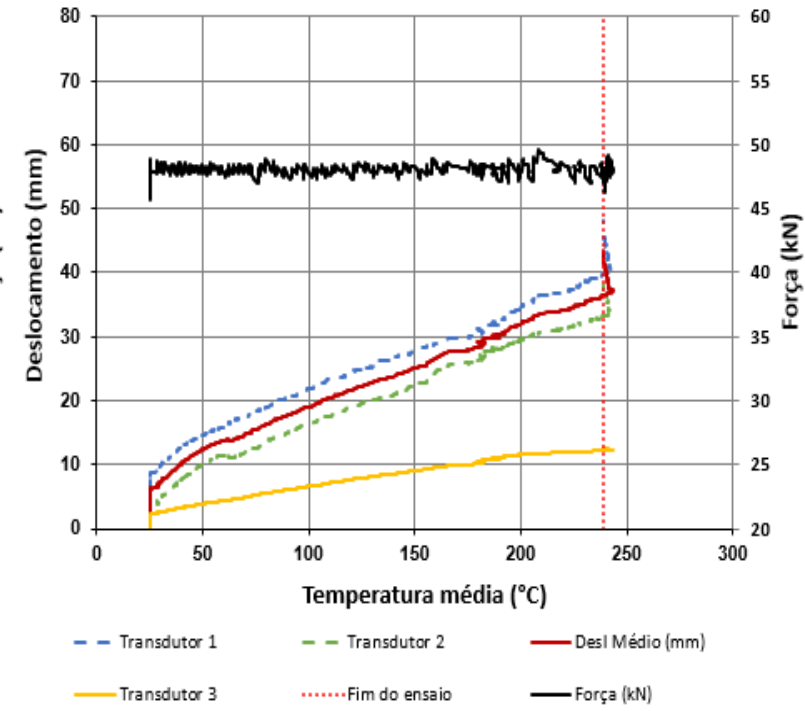

(b)

Figura 3.27 - Comportamento termoestrutural da viga mista (II) em função de: (a) tempo do ensaio e (b) temperatura média do perfil metálico na seção central

Neste ensaio, felizmente não foi identificado ruptura dos cabos dos transdutores e, portanto, foi possível medir os três deslocamentos até o final do ensaio. Comparando as curvas obtidas na Figura $3.27 \mathrm{com}$ as curvas do ensaio anterior (mesmo fator de carga), apresentadas na Figura 3.25, nota-se uma certa semelhança entre elas. Ambos os resultados ao término do ensaio indicam um deslocamento na extremidade da viga próximo a $13 \mathrm{~mm}$, enquanto no centro do vão esse deslocamento é da ordem de $45 \mathrm{~mm}$.

Em relação ao aquecimento do perfil metálico, tem-se na Figura 3.28 as temperaturas medidas em diferentes pontos da seção S1 e S3 da viga mista de aço e concreto parcialmente revestida. 

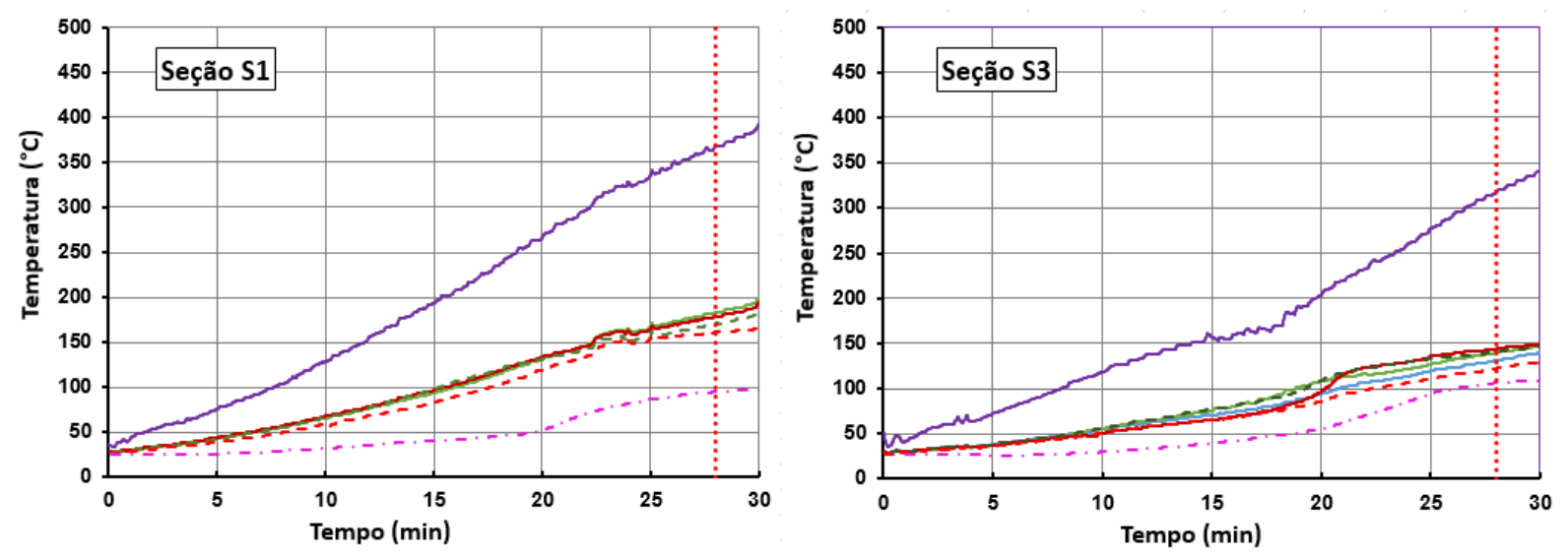

Figura 3.28 - Temperaturas medidas nas seções S1 e S3 durante o ensaio da viga mista de aço e concreto parcialmente revestida (II)

Assim como ocorreu no ensaio I, alguns pontos também apresentaram erros de leitura, isto é, a temperatura não foi medida corretamente. Entretanto, no caso deste ensaio II esses pontos não foram lançados no gráfico, por motivos de melhor análise das medidas em que as temperaturas estão corretas.

Analisando apenas os valores medidos corretamente, pode-se verificar que a mesa inferior (Tx.5) do perfil apresentou as maiores temperaturas, entre $300^{\circ} \mathrm{C} \mathrm{e}$ $400^{\circ} \mathrm{C}$, enquanto a mesa superior (Tx.1), a alma (Tx.2 e Tx.3) e as armaduras (Tx.6 e Tx.7) finalizaram o ensaio em temperaturas mais baixas, cerca de $150^{\circ} \mathrm{C}$ a $200^{\circ} \mathrm{C}$, ou seja, sem sofrer deterioração das propriedades mecânicas. Já a temperatura no concreto (Tx.9) ficou na ordem dos $100^{\circ} \mathrm{C}$.

Pode-se perceber que os valores de temperatura obtidos neste ensaio foram um pouco menores, mas ainda bem parecidos com o do ensaio anterior, comprovando uma certa eficiência no método utilizado. Por outro lado, algumas medidas precisam ser mais bem pensadas e melhoradas para os próximos estudos de estruturas em situação de incêndio a serem realizados no laboratório da EESC, como por exemplo uma melhor maneira de soldagem dos cabos termopares, a fim de evitar que alguns pontos sejam perdidos. 


\subsubsection{Viga mista de aço e concreto parcialmente revestida - Ensaio III}

Por fim, foi realizado um último ensaio voltado para as viga mista de aço e concreto parcialmente revestida em situação de incêndio, porém desta vez aplicando um fator de carga igual a $45 \%$ em relação à carga de ruptura encontrada no ensaio em temperatura ambiente.

O ensaio apresentou duração total de 23 minutos, quando a temperatura média da viga indicava aproximadamente $185^{\circ} \mathrm{C}$. No entanto, durante o ensaios em um instante próximo dos 14 minutos, houve rompimento dos cabos dos transdutores $1 \mathrm{e}$ 2, devido ao desplacamento de concreto causado pelas altas temperaturas. A partir de então, não foi possível medir o deslocamento da viga no centro do vão, conforme indica a Figura 3.29.

O rompimento dos cabos dos transdutores no centro do vão da viga é outra questão a ser mais bem analisada para os próximos ensaios de sistemas estruturais em situação de incêndio a serem realizados no Laboratório da EESC. Uma ideia é prendê-los somente na parte metálica da viga, talvez por um gancho soldado na mesma, para que, assim, o desplacamento de concreto (normal em elevadas temperaturas) não influencie na medida dos deslocamentos.

Ainda que os cabos tenham sido rompidos, foi possível determinar uma taxa de deslocamento médio no meio do vão de $1,65 \mathrm{~mm} / \mathrm{min}$, totalizando $23 \mathrm{~mm}$ ao final dos 14 minutos, instante no qual os cabos dos transdutores foram rompidos.

Pode-se notar que essa taxa foi pouco superior à calculada no ensaio anterior, que apresentou um deslocamento de cerca de $18 \mathrm{~mm}$ aos 14 minutos, fato que pode ser entendido pelo maior fator de carga aplicado (45\%). No entanto, trata-se de diferença não tão significativa, evidenciando a elevação de temperatura como fator de extrema influência na perda das propriedades mecânicas da estrutura. 
(a)

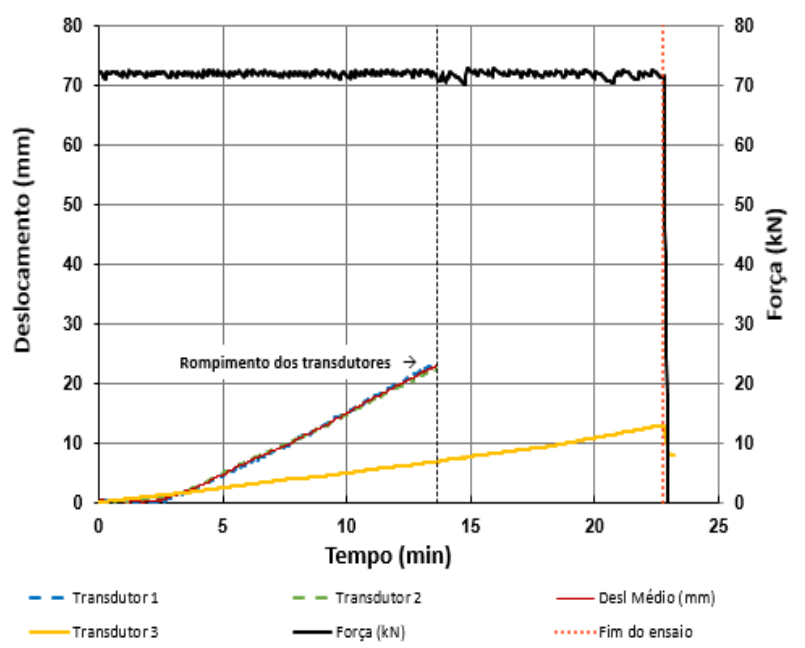

(b)

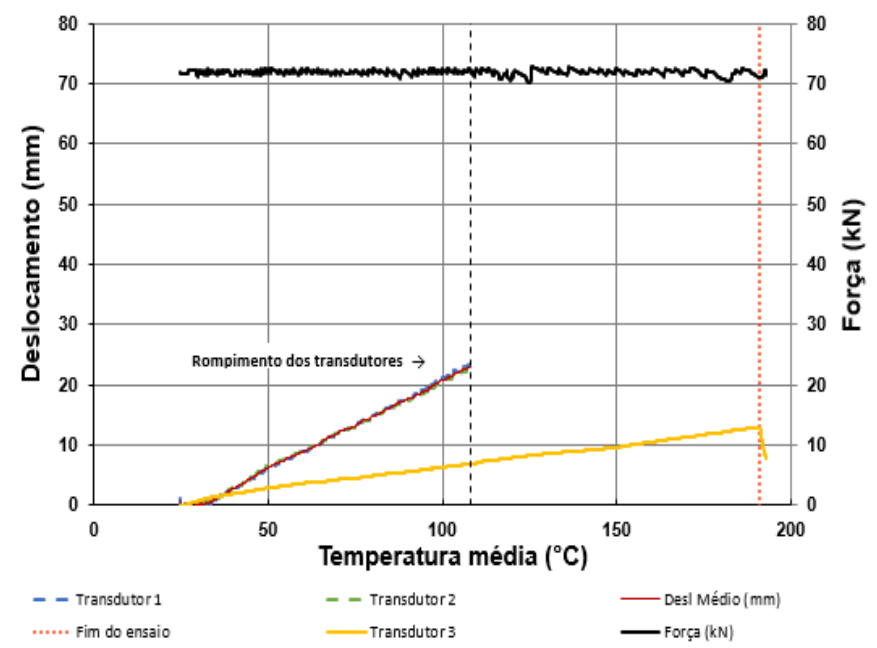

Figura 3.29 - Comportamento termoestrutural da viga mista (III) em função de:

(a) tempo do ensaio e (b) temperatura média do perfil metálico na seção central

Quanto às temperaturas medidas durante o ensaio, são apresentados na Figura 3.30 os valores dessas mesmas em diferentes pontos nas seções S1 e S3 da viga analisada.
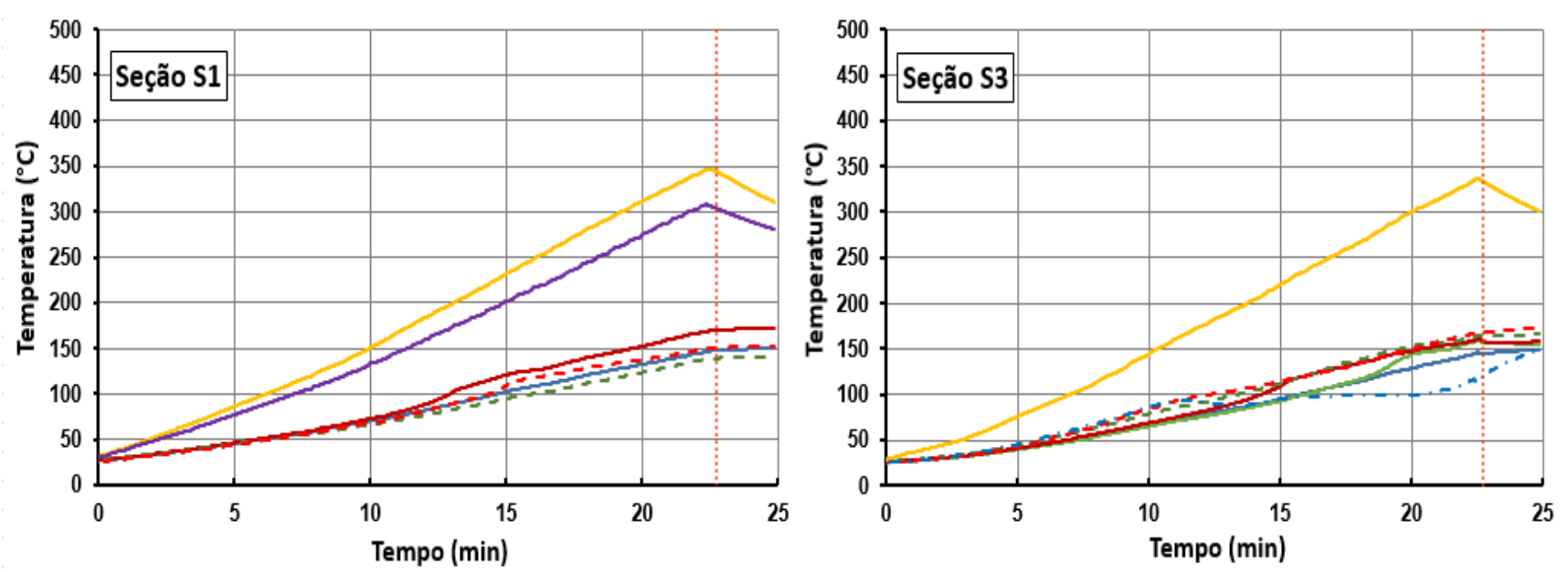

Figura 3.26 - Temperaturas medidas nas seções S1 e S3 durante o ensaio da viga mista de aço e concreto parcialmente revestida (III)

Observando os gráficos anteriores, pode-se perceber que alguns pontos também não aparecem neste ensaio, pois não marcaram a temperatura de maneira correta e, portanto, não foram considerados. Analisando, assim, os valores que foram 
medidos corretamente, verifica-se que a mesa inferior (Tx.4 e Tx.5) do perfil, sem revestimento, apresentou as maiores temperaturas, entre $300^{\circ} \mathrm{C}$ e $350^{\circ} \mathrm{C}$. Já a mesa superior (Tx.1), a alma (Tx.2 e Tx.3) e as armaduras (Tx.6 e Tx.7) finalizaram o ensaio em temperaturas mais baixas, cerca de $150^{\circ} \mathrm{C}$, ou seja, sem sofrer deterioração das propriedades mecânicas. O mesmo foi observado na temperatura do concreto (Tx.8), que também ficou na ordem dos $150^{\circ} \mathrm{C}$.

Conforme o esperado, os resultados obtidos para a temperatura em diferentes pontos da viga são similares aos obtidos nos dois ensaios anteriores, fato que destaca a eficiência do concreto como revestimento ao perfil metálico, protegendo os componentes internos do aquecimento elevado e, portanto, da perda de propriedades mecânicas.

\subsection{Ocorrências notáveis}

As Figuras 3.31 e 3.32 ilustram a configuração deslocada final das vigas de aço e mistas de aço e concreto após serem ensaiadas.

Com relação á viga de aço, conforme figura 3.31, é possível observar que, mesmo após o resfriamento, a mesma apresenta um deslocamento residual vertical da ordem de $12,5 \mathrm{~mm}$ no meio do vão, enquanto que na viga mista de aço e concreto, conforme figura 3.32, esse mesmo deslocamento resultou praticamente nulo.

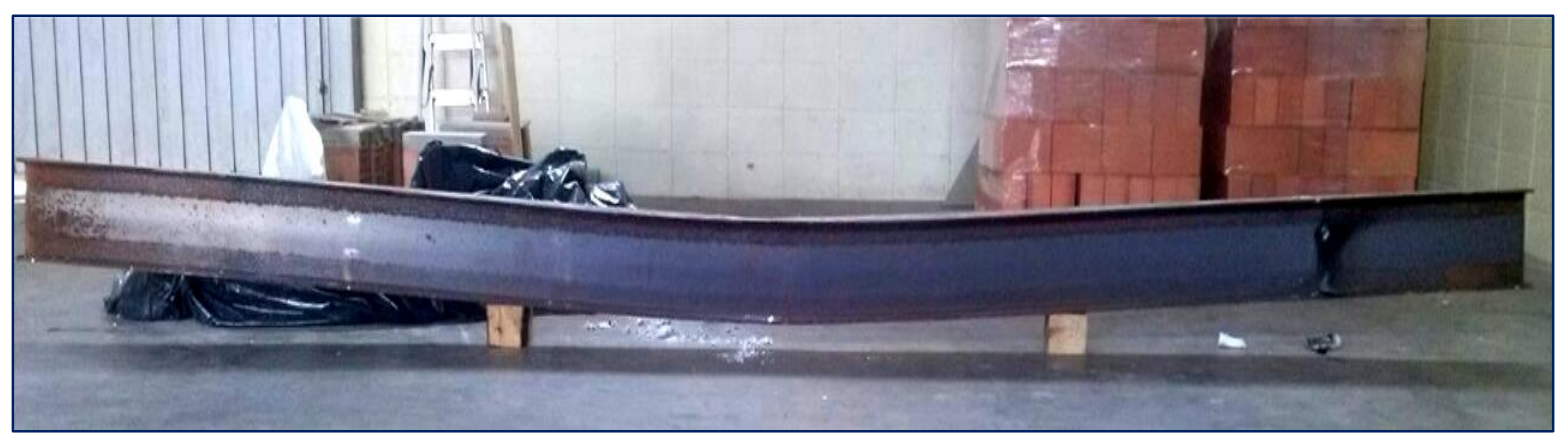

Figura 3.31 - Configuração final da viga de aço isolada após submetida ao ensaio em temperatura elevada 


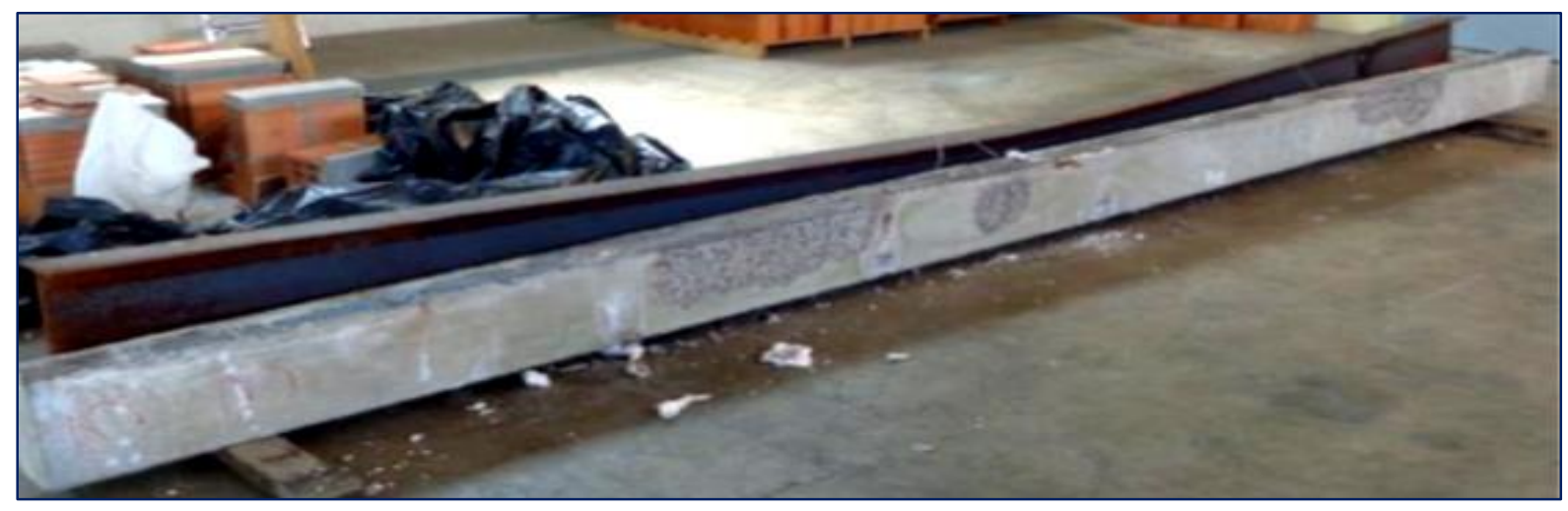

Figura 3.32 - Configuração final das vigas de aço isolada e viga mista de aço e concreto parcialmente revestida após submetida ao ensaio em temperatura elevada

Em relação ao concreto, verifica-se a ocorrência de lascamento (spalling) desse mesmo material em partes da viga. Ao contrário do esperado, o lascamento não foi acentuado, mesmo tendo sido realizado o ensaio com apenas 30 dias após a concretagem, quando o concreto ainda apresenta grande quantidade de água em seu interior, conforme mostra a Figura 3.33.
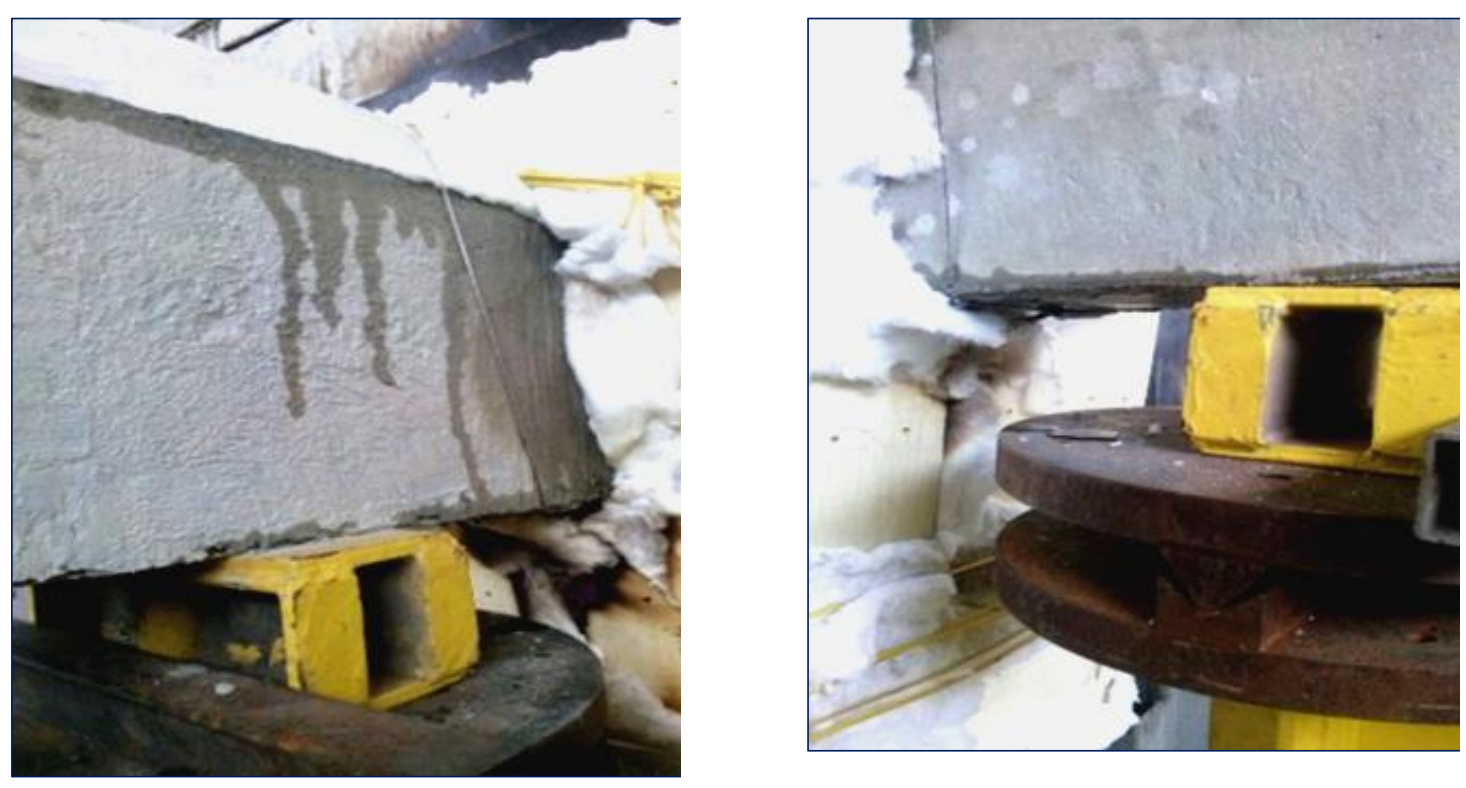

Figura 3.33 - Liberação de água do concreto devido à alta temperatura 


\subsection{Comparação entre Curvas de incêndio: Experimental x ISO 834:1999}

Foi comentado anteriormente que o forno horizontal é capaz de reproduzir a temperatura dos gases de acordo com a curva de incêndio-padrão proposta pela ISO 834:1999. A partir das temperaturas medidas dentro do forno, em nove pontos diferentes, durante o segundo ensaio de viga mista de aço e concreto em situação de incêndio, construiu-se um gráfico que mostra a evolução dessas temperaturas, representada no eixo y, em função do tempo, representado no eixo x. A Figura 3.34
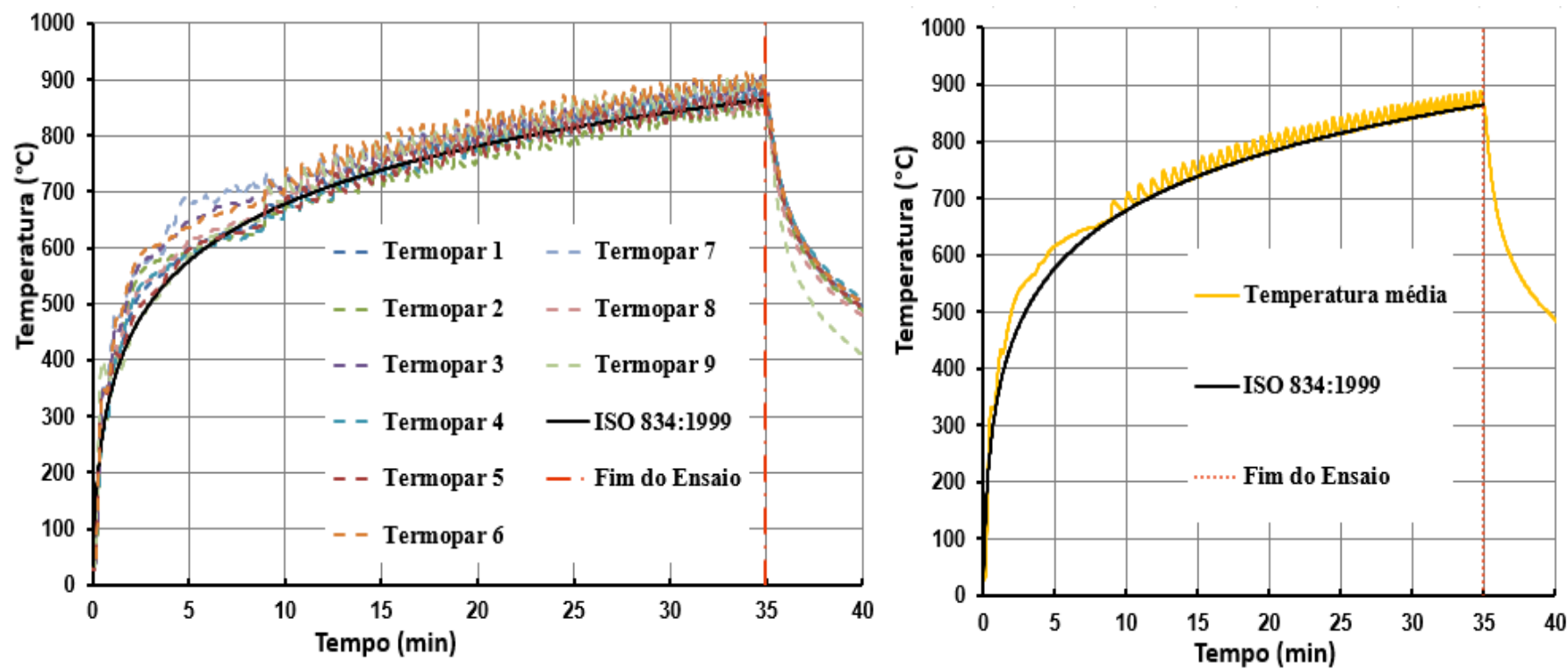

apresenta a curva obtida comparada com a curva da ISO 834:1999.

Figura 3.30 - Comparação da curva de incêndio obtida através das temperaturas medidas dentro do forno com a curva de incêndio proposta pela ISO 834:1999

Conforme apresentado, o modelo proposto pela ISO 834:1999 segue a equação logarítmica 3.1, a qual depende somente do tempo de exposição ao fogo e da temperatura inicial, comumente adotado oo valor de $20^{\circ} \mathrm{C}$.

$$
T=20+345 \log (8 t+1)
$$

Equação 3.1

Pode-se notar que as temperaturas medidas dentro do forno se aproximaram satisfatoriamente das temperaturas obtidas por tal modelo, comprovando sua eficiência na representação do incêndio padronizado. Tal constatação enquanto 
similaridades das temperaturas permite considerar que tal equipamento pode ser utilizado para fins de análises experimentais e numéricas de estruturas submetidas à situação de incêndio.

\subsection{Considerações Preliminares}

Em relação aos ensaios das vigas (metálica e mista de aço e concreto parcialmente revestida) realizados em situação de incêndio, foi possível constatar que, para uma mesma carga aplicada (fatores de 30 e 45\%), foram observados deslocamentos muito mais expressivos se comparados aos valores obtidos nos ensaios à temperatura ambiente, fato que comprova como as elevadas temperaturas comprometem as propriedades térmicas e mecânicas dos materiais e, consequentemente, sua capacidade resistente.

Deve-se ressaltar, ainda, que estes ensaios são inovadores no Brasil e, portanto, algumas dificuldades foram encontradas, como a perda de medidas de temperatura e/ou deslocamento. Apesar disso, através da comparação dos resultados obtidos pelas vigas metálica e mistas de aço e concreto, pode-se verificar o efeito benéfico do revestimento de concreto ao perfil metálico, responsável por um ganho expressivo de resistência ao fogo quando comparado aos elementos puramente metálicos.

Nota-se, também, que estes ensaios permitiram significativo ganho de experiência a todos participantes, sejam eles alunos da graduação ou do mestrado, professores e técnicos de laboratório. Além disso, servirão como ponto de partida para as demais pesquisas que serão desenvolvidas no forno do laboratório de estruturas da EESC/USP.

Por outro lado, vale destacar que, no referente às vigas puramente metálicas, não foram realizados ensaios no forno com maiores fatores de carga, por motivos de segurança, pois se sabe que o elemento metálico isolado deve apresentar elevadas taxas de aquecimento, reduzindo suas propriedades mecânicas muito rapidamente, razão pela qual se acredita que o ensaio seria finalizado com menos de sete minutos, o que o tornaria pouco representativo. Adicionalmente, tal aspecto provocaria 
deslocamentos excessivos, os quais poderiam danificar os equipamentos de ensaio, como os atuadores hidráulicos, os transdutores e os revestimentos laterais. 


\section{Capítulo 4}

\section{ANÁLISES COMPARATIVAS}

\subsection{Informações Preliminares}

Neste capítulo são apresentadas análises comparativas feitas com diversas informações apresentados nos capítulos anteriores desta dissertação. O primeiro item apresentado é o comparativo das cargas máximas de ruptura encontradas experimentalmente em ensaios de temperatura ambiente com o valor teórico calculado aqui, posteriormente, para os dois casos de vigas em estudo (viga metálica e viga mista de aço e concreto parcialmente revestida).

É apresentada também uma modelagem térmica bidimensional feita para perfis de vigas metálica e mista de aço e concreto. São apresentados as propriedades térmicas dos materiais utilizados na simulação numérica no ABAQUS, bem como as curvas de temperatura por tempo de incêndio e os perfis de temperatura de cada um deles.

Há uma análise dos deslocamentos apresentados nas vigas. Os deslocamentos analisados são os próximos aos apoios das vigas e no meio delas. Uma comparação é feita com os deslocamentos dos ensaios em temperatura ambiente e altas temperaturas de cada tipo de viga. 
Foi feita uma análise comparativa dos dois ensaios que foram feitas em altas temperaturas e com o mesmo fator de carga. Características desses ensaios foram descritas e comparadas.

Por fim, há uma comparação dos resultados obtidos pelo presente programa experimental e o trabalho de Piloto que é exclusivo de vigas mistas de aço e concreto parcialmente revestidas em escala reduzida e em altas temperaturas.

\subsection{Cálculo carga máxima teórica para a viga metálica}

Para o cálculo teórico da carga de ruptura, será calculado primeiramente o valor do seu Momento de Plastificação $(\mathrm{Mpl})$. Sabendo o valor do momento chegaremos ao valor da carga máxima teórica e assim pode ser feito um comparativo do valor teórico com o encontrado experimentalmente no ensaio realizado.

\subsubsection{Momento de plastificação}

O momento de plastificação ( $\mathrm{Mpl}$ ) é calculado pela equação 4.1.

$$
M_{p l}=f_{y} . Z_{x}
$$

Onde:

Mplé o momento de plastificação (kN.cm)

$f_{y}$ é a resistência de escoamento do aço $\left(\mathrm{kN} / \mathrm{cm}^{2}\right)$

Zx é o módulo plástico de resistência máxima em relação ao eixo x $\left(\mathrm{cm}^{3}\right)$

O valor de fy é encontrado na norma ABNT NBR 8800 , onde para perfil laminado (A572), grupo 1 , classe 50 , temos o valor de $34,5 \mathrm{kN} / \mathrm{cm}^{2}$.

O valor de $Z_{x}$ pode ser calculado pela fórmula dada na Tabela 4.1. 
Tabela 4.1 - Fórmula para encontrar o valor de Z para uma seção com perfil I

\begin{tabular}{|l|c|}
\hline \multicolumn{1}{|c|}{ Seção } & $\begin{array}{c}\text { Módulo Resistente } \\
\text { Plástico }(\mathbf{Z})\end{array}$ \\
\hline Perfil-I: & $b_{f} \cdot t_{f} \cdot\left(d-t_{f}\right)+$ \\
\hline b & $\frac{t_{w} \cdot\left(d-2 \cdot t_{f}\right)^{2}}{4}$ \\
\hline
\end{tabular}

Para a viga em estudo temos os seguintes valores para a sua seção:

$b_{f}=14,6 \mathrm{~cm}$

$\mathrm{tf}_{\mathrm{f}}=0,91 \mathrm{~cm}$

$\mathrm{h}=24 \mathrm{~cm}$

$\mathrm{d}=25,8 \mathrm{~cm}$

$\mathrm{t}_{\mathrm{w}}=0,61 \mathrm{~cm}$

Aplicando esses valores na fórmula de Zx encontramos, para ele, o valor de $418,38 \mathrm{~cm}^{3}$.

Assim, temos que $\mathrm{Mpl}=418,38 \times 34,5=\mathbf{1 4 . 4 3 4 , 1 1} \mathbf{k N} . \mathbf{c m}$.

\subsubsection{Carga máxima teórica}

Nesse trabalho, temos como configuração de aplicação de carga uma viga simplesmente apoiada, com uma carga concentrada sendo aplicada ao centro.

Nessa configuração, o valor máximo de momento é dado pela equação 4.2. 


$$
M=\frac{P \times l}{4}
$$

Onde:

$\mathrm{M}$ = momento máximo $(\mathrm{kN} . \mathrm{cm})$

$\mathrm{P}=$ carga máxima aplicada $(\mathrm{kN})$

$I=$ comprimento da viga $(\mathrm{cm})$

Assim, temos que:

$$
14.434,11=\frac{P \times 510}{4}
$$

$$
P=113,20 \mathrm{kN}
$$

\subsubsection{Comparativo}

O valor da carga máxima teórica calculada é de $113,20 \mathrm{kN}$. No ensaio de temperatura ambiente, para a viga metálica, foi encontrado o valor para essa carga de $123 \mathrm{kN}$.

Fazendo uma comparação entre esses valores, encontramos que o valor experimental é aproximadamente 8\% maior que o valor teórico. Essa diferença pode ser explicada por erros acidentais ou aleatórios no momento do ensaio, como por exemplo, imperícia dos operadores, falha no posicionamento da viga na montagem do ensaio, entre outros 


\subsection{Cálculo carga máxima teórica para a viga mista de aço e concreto parcialmente revestida}

Para o cálculo teórico da carga de ruptura, será calculado o momento de plastificação da seção para depois ser calculado o valor da carga máxima. Para o cálculo do momento necessita-se conhecer a posição da linha neutra para em seguida fazer-se o somatório de momentos gerados e assim chegarmos ao valor do momento máximo. Após esse cálculo, pela formula do momento máximo para uma viga biapoiada com uma carga aplicada pontualmente ao centro, encontraremos o valor da carga máxima.

\subsubsection{Valores a serem considerados para os cálculos posteriores}

- perfil laminado (A572) $-f_{y}=34,5 \mathrm{kN} / \mathrm{cm}^{2}$

- armadura (aço CA 50) $-\mathrm{f}_{\mathrm{s}}=52 \mathrm{kN} / \mathrm{cm}^{2}$

- concreto (classe C60) - $f_{c k}=6 \mathrm{kN} / \mathrm{cm}^{2}$

Coeficientes minoração:
- perfil : $\gamma_{m}=1,0$
Assim, $f_{y d}=34,5 \mathrm{kN} / \mathrm{cm}^{2}$
- armadura: $\eta_{s}=1,15$
Assim, $f_{s d}=43,48 \mathrm{kN} / \mathrm{cm}^{2}$
- concreto: $y_{c}=1,4$
Assim, $\mathrm{f}_{\mathrm{cd}}=4,29 \mathrm{kN} / \mathrm{cm}^{2}$ 


\subsubsection{Cálculo da posição da linha neutra}

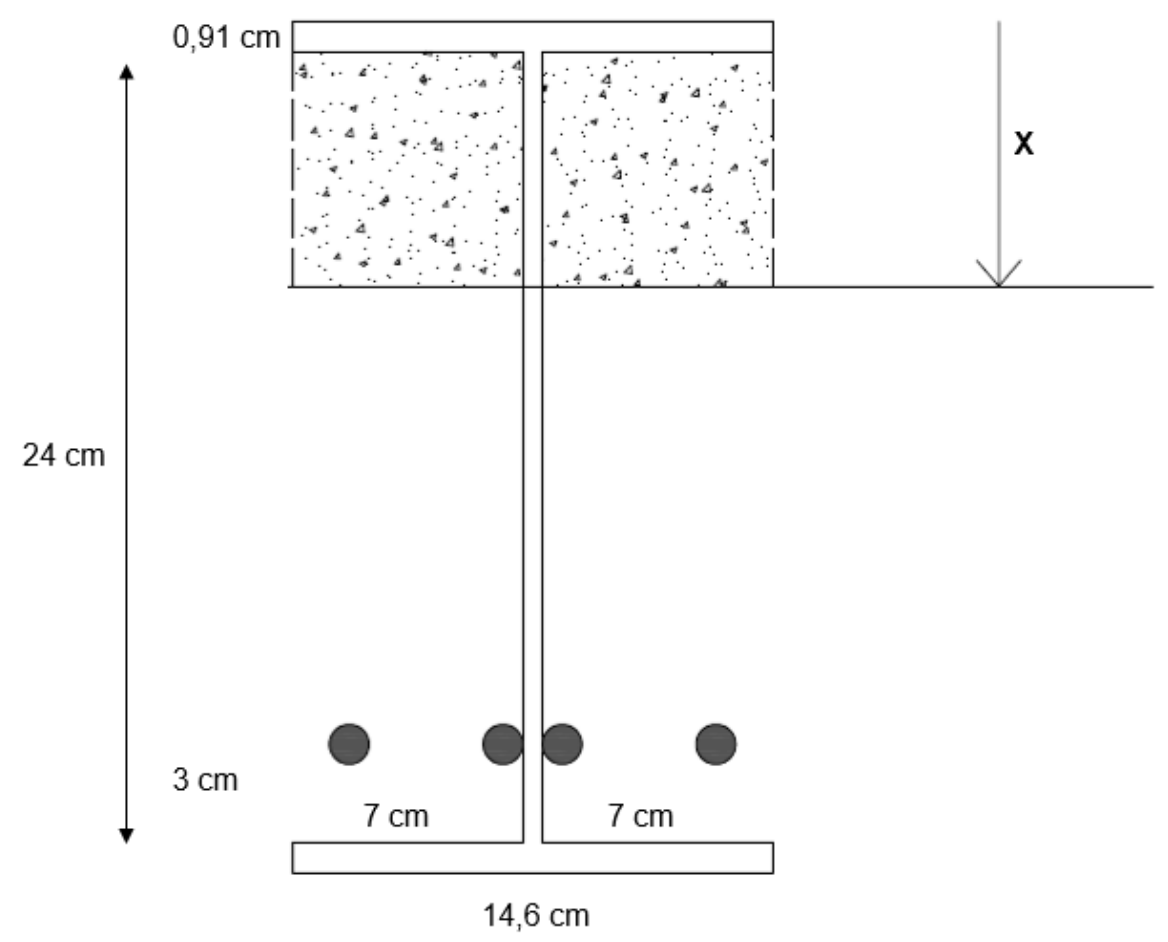

Figura 4.1 - Posição da Linha Neutra na seção

Podemos calcular a posição da linha neutra (representada por x na Figura 4.1) através da equação abaixo:

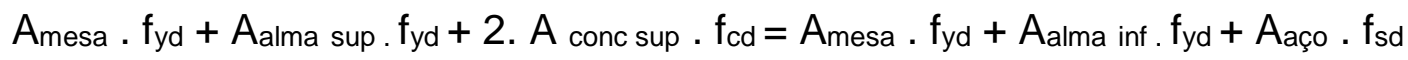

Resolvendo a equação acima temos que o valor de $x$, que representa a posição da linha neutra na seção, é 7,48 cm. 


\subsubsection{Cálculo do momento máximo}

Áreas:

- Mesa $=0,91 \times 14,6=13,29 \mathrm{~cm}^{2}$

- Alma superior a linha neutra $=(7,48-0,91) \times 0,61=4,01 \mathrm{~cm}^{2}$

- Concreto superior a linha neutra $=2 \times(7,48-0,91) \times 7=91,98 \mathrm{~cm}^{2}$

- Alma inferior a linha neutra $=(18,32-0,91) \times 0,61=10,62 \mathrm{~cm}^{2}$

- Armadura inferior $=4 \times \pi \times 0,5^{2} / 4=0,79 \mathrm{~cm}^{2}$

$\mathrm{F}_{\mathrm{id}}\left(\mathrm{kN} / \mathrm{cm}^{2}\right)$ :

- perfil : $f_{y d}=34,5 \mathrm{kN} / \mathrm{cm}^{2}$

- armadura: $f_{s d}=43,48 \mathrm{kN} / \mathrm{cm}^{2}$

- concreto: $f_{c d}=4,29 \mathrm{kN} / \mathrm{cm}^{2}$

Diagrama das distâncias de cada força resultante $\left(d_{i}\right)$ até a linha neutra é representado pela Figura 4.2.

A equação 4.3 mostra como é calculado o momento máximo na viga mista de aço e concreto parcialmente revestida.

$$
M=\sum A_{i} x f_{i d} x d_{i}
$$

Fazendo os cálculos da equação acima, temos que $\mathbf{M}=18.617,99$ kN.cm 


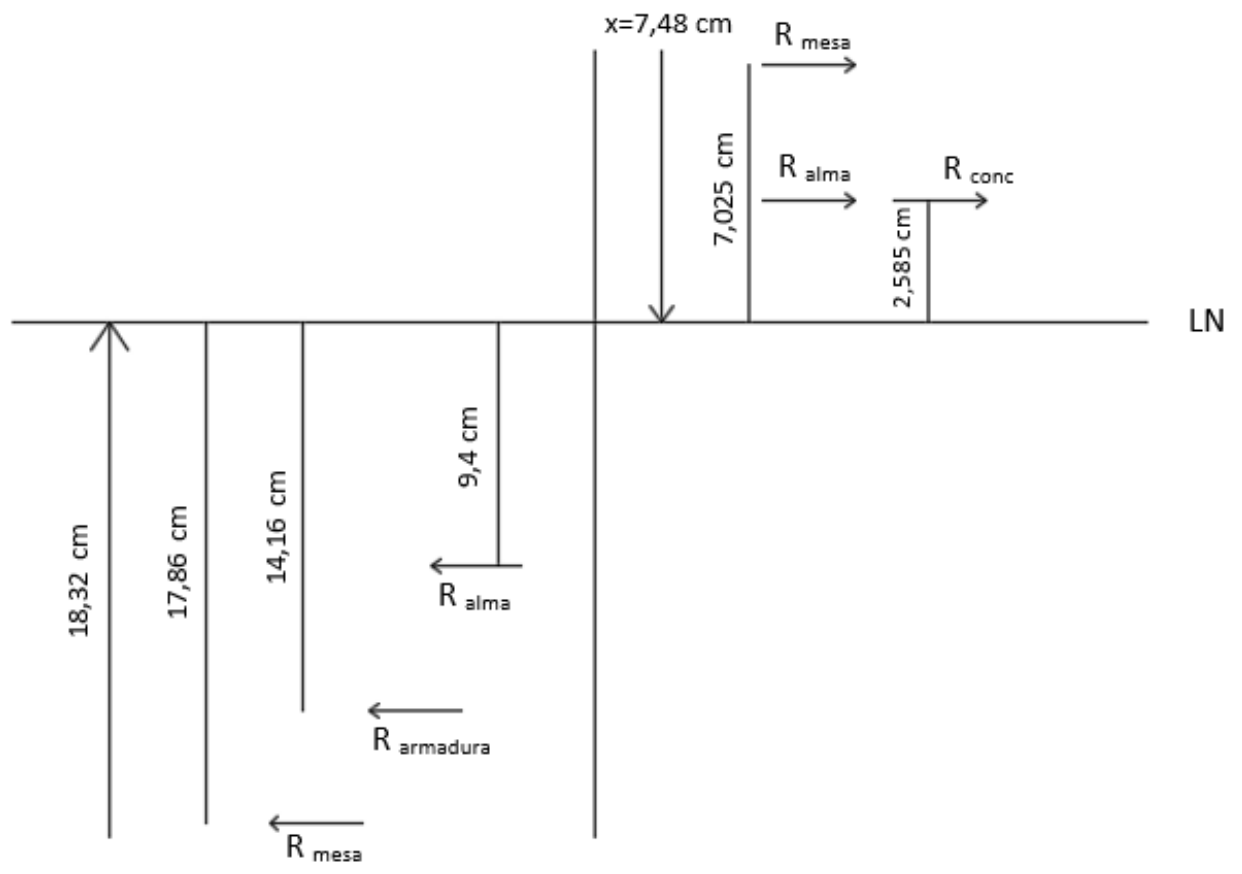

Figura 4.2 - Diagrama $d_{i}$

\subsubsection{Cálculo da carga máxima}

Nesse trabalho, temos como configuração de aplicação de carga uma viga biapoiada, com uma carga concentrada sendo aplicada ao centro.

Nessa configuração, o valor máximo de momento é dado pela equação 4.2.

Assim, temos que:

$18.617,99=\frac{P \times 510}{4}$

$P=146,02 k N$ 


\subsubsection{Comparativo}

O valor da carga máxima teórica calculada é de $146,02 \mathrm{kN}$. No ensaio de temperatura ambiente, para a viga mista, foi encontrado o valor para essa carga de $164 \mathrm{kN}$.

Fazendo uma comparação entre esses valores, encontramos que o valor experimental é aproximadamente $11 \%$ maior que o valor teórico. Essa diferença pode ser explicada por erros acidentais ou aleatórios no momento do ensaio, como por exemplo, imperícia dos operadores, falha no posicionamento da viga na montagem do ensaio, entre outros.

\subsection{Modelagem térmica bidimensional}

Neste tópico são apresentadas duas simulações numéricas referente ao programa experimental desenvolvido em temperaturas elevadas. A primeira constitui uma modelagem térmica de uma seção transversal metálica e teve como finalidade uma comparação entre os resultados encontrados experimentalmente e os resultados obtidos através do ABAQUS.

A segunda modelagem teve como finalidade usar os resultados obtidos através da modelagem no ABAQUS para uma comparação com os resultados experimentais encontrados para a viga mista de aço e concreto.

\subsubsection{Simulação numérica}

Neste item foi avaliada uma seção transversal das vigas metálica e mista de aço e concreta, já apresentada no tópico 3.2 desta dissertação (Figura 3.2), onde foi considerada a atuação da curva de incêndio padrão segundo a ISO 834 (1999). A atuação do incêndio ocorre nas faces laterais e inferior do perfil da viga, enquanto a face superior permanece em temperatura ambiente.

Para as superfícies submetidas a altas temperaturas aplicou-se o coeficiente de troca de calor por convecção de $25 \mathrm{~W} /\left(\mathrm{m}^{2}{ }^{\circ} \mathrm{C}\right)$ e a emissividade resultante igual a 
0,8 . Já para a superfície a temperatura ambiente aplicou-se o valor recomendado pelo EN 1991-1-2:2002 para o coeficiente de troca de colar por convecção de $9 \mathrm{~W} /\left(\mathrm{m}^{2}\right.$ $\stackrel{\circ}{ })$.

$\mathrm{Na}$ discretização dos elementos foi utilizado um elemento finito presente na biblioteca do ABAQUS, o DC2D4, que é um elemento linear de 4 nós usado para análises de transferência de calor. Empregou-se uma malha de elementos finitos na forma aproximada de um quadrado com $5 \mathrm{~mm}$ de dimensão.

Já para a análise numérica não linear foi adotado na ABAQUS um procedimento do tipo transferência de calor que emprega um critério de análises de convergência de fluxo de calor com tolerância de 0,005.

A variação das propriedades térmicas de concreto e do aço foram consideradas, respectivamente, de acordo com a ABNT NBR 15200:2012 e ABNT NBR 14323:2013 e são valores são apresentados a seguir.

\subsubsection{Propriedades térmicas do concreto}

Como já citado anteriormente, as propriedades térmicas do concreto aqui mostradas seguem as recomendações da ABNT NBR 15200:2012.

Para o cálculo da condutividade térmica do concreto de densidade normal $(\lambda)$ em função da temperatura $\left(\theta_{c}\right)$ é apresentada a equação 4.4. Através dessa equação é apresentada na Figura 4.3 a curva de condutividade térmica do concreto em função da temperatura.

$$
\lambda=1,36-0,36 \cdot \frac{\theta_{c}}{100}+0,0057 \cdot\left(\frac{\theta_{c}}{100}\right)^{2}
$$




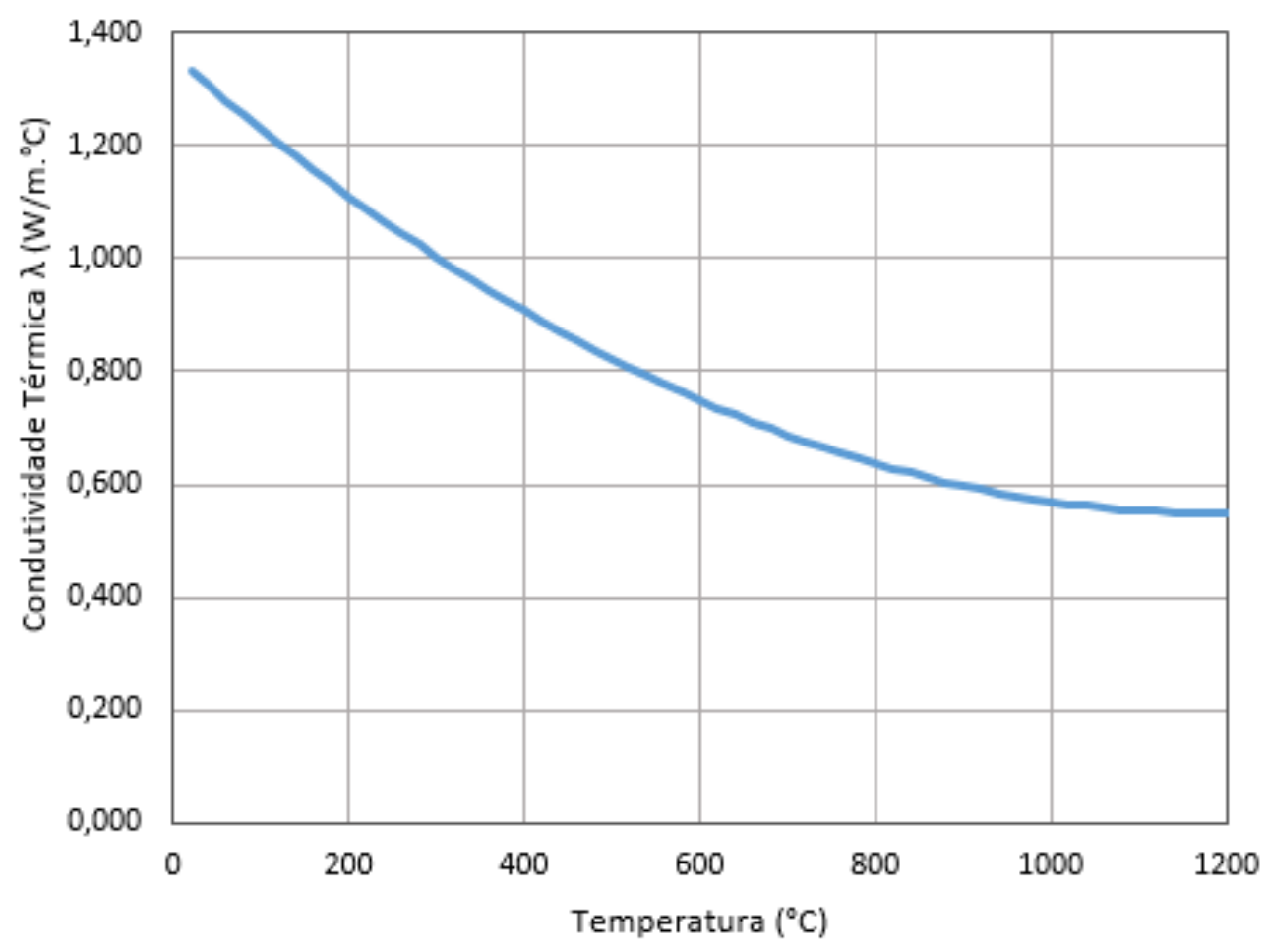

Figura 4.3 - Gráfico Condutividade Térmica do Concreto x Temperatura

O calor específico do concreto, $c_{p}(\theta)$, em função da temperatura $(\theta)$, é determinado pelas equações 4.5. Quando a umidade não for considerada explicitamente no modelo de cálculo, o calor específico pode ser considerado um valor constante $\left(c_{p, t o t}\right)$ entre $100^{\circ} \mathrm{C}$ e $115^{\circ} \mathrm{C}$, equações 4.6 , com um decréscimo linear entre $115^{\circ} \mathrm{C}$ e $200^{\circ} \mathrm{C}$.

A Figura 4.4 traz o gráfico que representa o calor específico do concreto em função da temperatura.

$$
\begin{aligned}
& c_{p}(\theta)=900 \frac{\mathrm{J}}{\mathrm{kg} \cdot{ }^{\circ} \mathrm{C}} \operatorname{para} 20^{\circ} \mathrm{C} \leq \theta \leq 100^{\circ} \mathrm{C} \\
& c_{p}(\theta)=900+(\theta-100)\left(\frac{\mathrm{J}}{\mathrm{kg} \cdot{ }^{\circ} \mathrm{C}}\right) \operatorname{para} 100^{\circ} \mathrm{C} \leq \theta \leq 200^{\circ} \mathrm{C} \\
& c_{p}(\theta)=1000+\left(\frac{\theta-200}{2}\right)\left(\frac{\mathrm{J}}{\mathrm{kg} \cdot{ }^{\circ} \mathrm{C}}\right) \operatorname{para} 200^{\circ} \mathrm{C} \leq \theta \leq 400^{\circ} \mathrm{C}
\end{aligned}
$$




$$
\begin{aligned}
& c_{p}(\theta)=1100 \frac{\mathrm{J}}{\mathrm{kg} \cdot{ }^{\circ} \mathrm{C}} \text { para } 400{ }^{\circ} \mathrm{C} \leq \theta \leq 1200^{\circ} \mathrm{C} \\
& c_{p, t o t}=900 \frac{\mathrm{J}}{\mathrm{kg} \cdot{ }^{\circ} \mathrm{C}} \text { para umidade } 0 \% \text { em peso } \\
& c_{p, \text { tot }}=1470 \frac{\mathrm{J}}{\mathrm{kg} \cdot{ }^{\circ} \mathrm{C}} \text { para umidade } 1,5 \% \text { em peso } \\
& c_{p, \text { tot }}=2020 \frac{\mathrm{J}}{\mathrm{kg} \cdot{ }^{\circ} \mathrm{C}} \text { para umidade } 3,0 \% \text { em peso }
\end{aligned}
$$

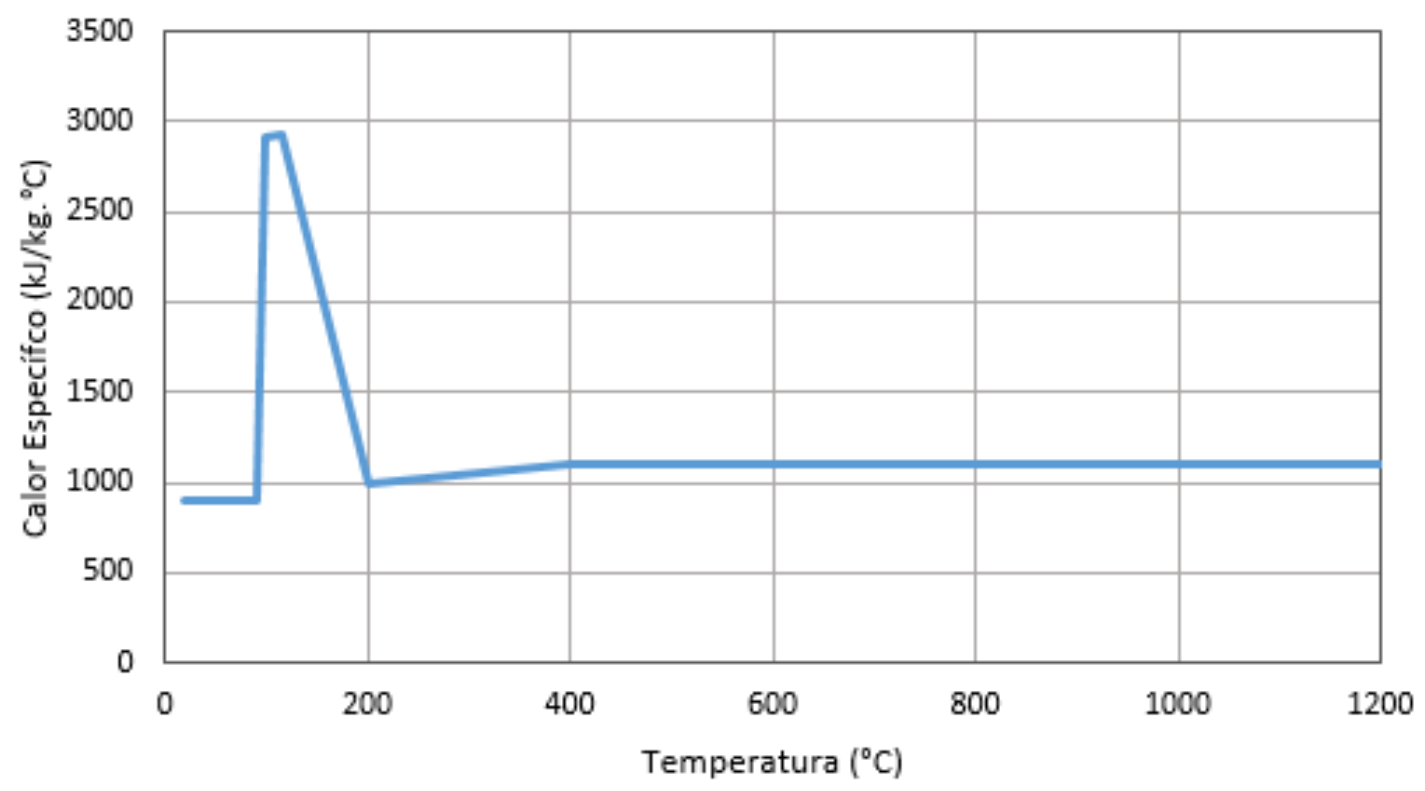

Figura 4.4 - Gráfico Relação Calor Específico do Concreto x Temperatura

A variação da densidade do concreto $(\rho)$ com a temperatura $(\theta)$ é apresentada pelas equações 4.7 , onde $\rho\left(\theta=20^{\circ} \mathrm{C}\right)$ é a densidade do concreto a $20^{\circ} \mathrm{C}$ que adotou-se $2500 \mathrm{~kg} / \mathrm{m}^{3}$. A figura 4.5 traz o gráfico que representa a variação da densidade do concreto com a temperatura. Nota-se que no gráfico é apresentado no eixo vertical a razão da densidade, onde 1 representa a densidade a $20^{\circ} \mathrm{C}$ com valor de $2500 \mathrm{~kg} / \mathrm{m}^{3}$. 


$$
\begin{aligned}
& \rho(\theta)=\rho\left(\theta=20^{\circ} \mathrm{C}\right) \text { para } 20^{\circ} \mathrm{C} \leq \theta \leq 115^{\circ} \mathrm{C} \\
& \rho(\theta)=\rho\left(\theta=20^{\circ} \mathrm{C}\right) \cdot\left(1-0,02 \cdot \frac{\theta-115}{85}\right) \text { para } 115^{\circ} \mathrm{C} \leq \theta \leq 200^{\circ} \mathrm{C} \\
& \rho(\theta)=\rho\left(\theta=20^{\circ} \mathrm{C}\right) \cdot\left(0,98-0,03 \cdot \frac{\theta-200}{200}\right) \text { para } 200^{\circ} \mathrm{C} \leq \theta \leq 400^{\circ} \mathrm{C} \\
& \rho(\theta)=\rho\left(\theta=20^{\circ} \mathrm{C}\right) \cdot\left(0,95-0,07 \cdot \frac{\theta-400}{800}\right) \text { para } 400^{\circ} \mathrm{C} \leq \theta \leq 1200^{\circ} \mathrm{C}
\end{aligned}
$$

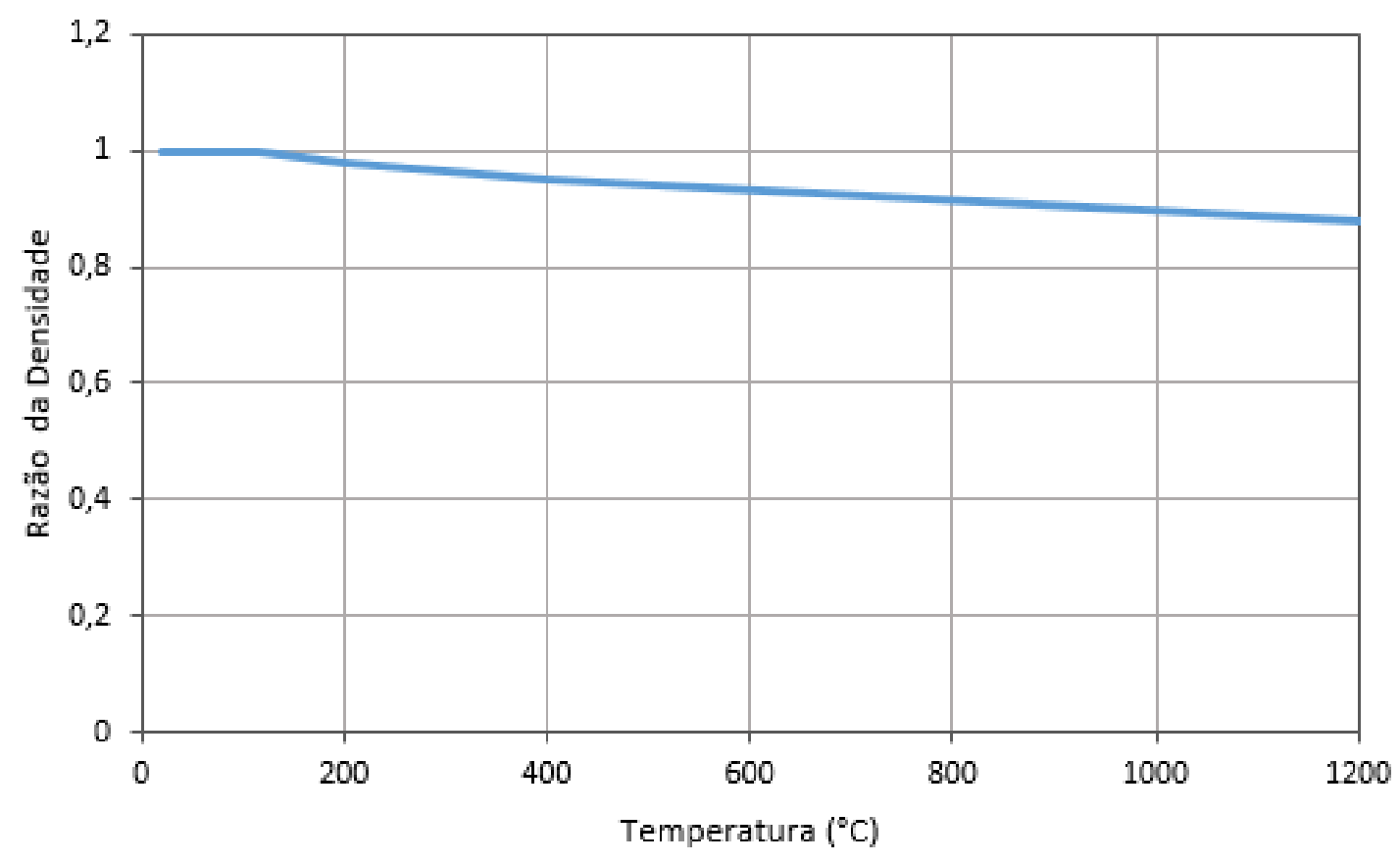

Figura 4.5 - Gráfico Relação Densidade do Concreto x Temperatura

\subsubsection{Propriedades térmicas do aço}

As propriedades do aço são baseadas no EN 1992-1-2:2004 e no EM 1994-12:2005. As normas brasileiras ABNT NBR 14323:2013 e ABNT NBR 15200:2012 são baseadas nelas.

A densidade do aço foi considerada constante no valor de $7850 \mathrm{~kg} / \mathrm{m}^{3}$ ao longo da modelagem, independendo da temperatura. 
A condutividade térmica do aço $\left(\lambda_{a}\right)$ é dada pelas equações 4.8 e a figura 4.6 mostra o gráfico que representa a condutividade térmica do aço em função da temperatura $\left(\theta_{a}\right)$ do aço.

$$
\begin{aligned}
& \lambda_{a}=54-3,33 \cdot 10^{-2} \cdot \theta_{a} \text { para } 20^{\circ} \mathrm{C} \leq \theta_{a} \leq 800^{\circ} \mathrm{C} \\
& \lambda_{a}=27,3 \text { para } 800^{\circ} \mathrm{C} \leq \theta_{a} \leq 1200^{\circ} \mathrm{C}
\end{aligned}
$$

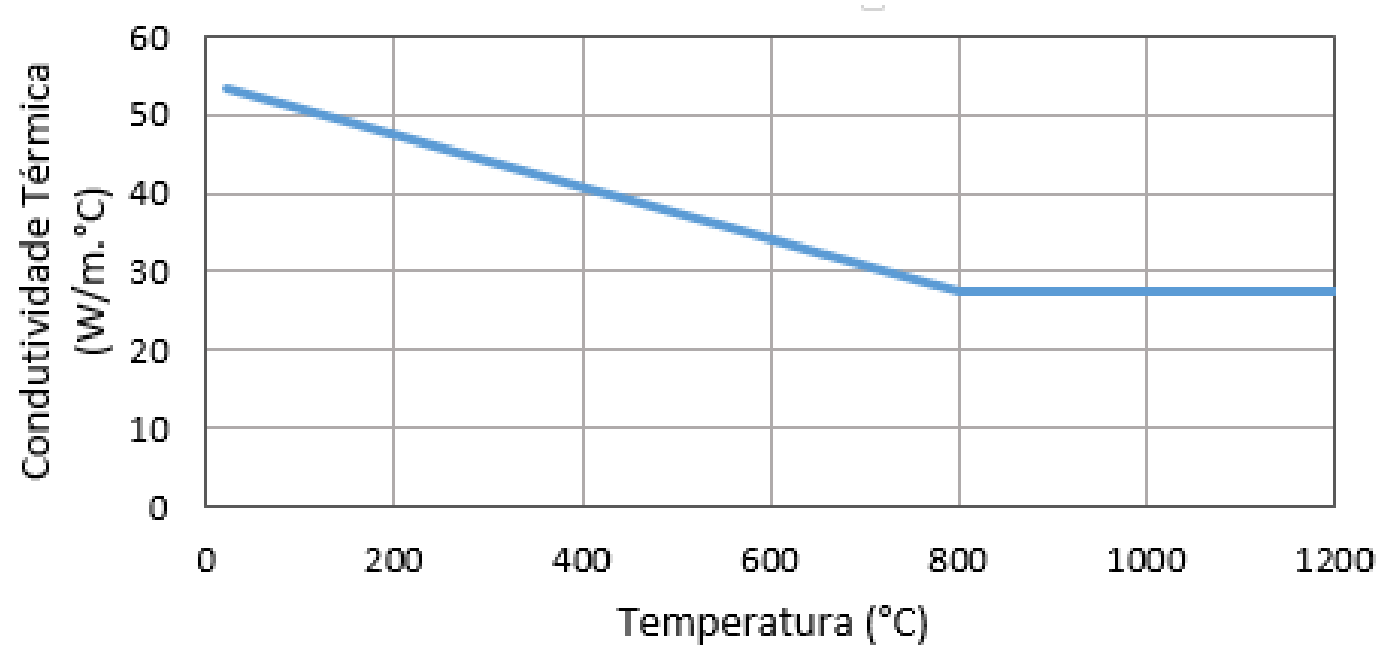

Figura 4.6 - Gráfico Relação Condutividade Térmica do aço x Temperatura

O calor específico do aço é determinado pelas equações 4.9. A figura 4.7 mostra o gráfico que representa a relação do calor específico com a temperatura do aço.

$$
\begin{aligned}
& c_{a}=425+7,73 \cdot 10^{-1} \cdot \theta_{a}-1,69 \cdot 10^{-3} \cdot \theta_{a}^{2}+2,22 \cdot 10^{-6} \cdot \theta_{a}^{3} \frac{\mathrm{J}}{\mathrm{kg} \cdot{ }^{\circ} \mathrm{C}} \operatorname{para} 20^{\circ} \mathrm{C} \leq \theta \leq 600^{\circ} \mathrm{C} \\
& c_{a}=666+\frac{13002}{738-\theta_{a}} \frac{\mathrm{J}}{\mathrm{kg} \cdot{ }^{\circ} \mathrm{C}} \operatorname{para} 600^{\circ} \mathrm{C} \leq \theta \leq 735^{\circ} \mathrm{C} \\
& c_{a}=545+\frac{17820}{\theta_{a}-731} \frac{\mathrm{J}}{\mathrm{kg} \cdot{ }^{\circ} \mathrm{C}} \operatorname{para~} 735^{\circ} \mathrm{C} \leq \theta \leq 900^{\circ} \mathrm{C} \\
& c_{a}=650 \frac{\mathrm{J}}{\mathrm{kg} \cdot{ }^{\circ} \mathrm{C}} \operatorname{para} 900{ }^{\circ} \mathrm{C} \leq \theta \leq 1200^{\circ} \mathrm{C}
\end{aligned}
$$




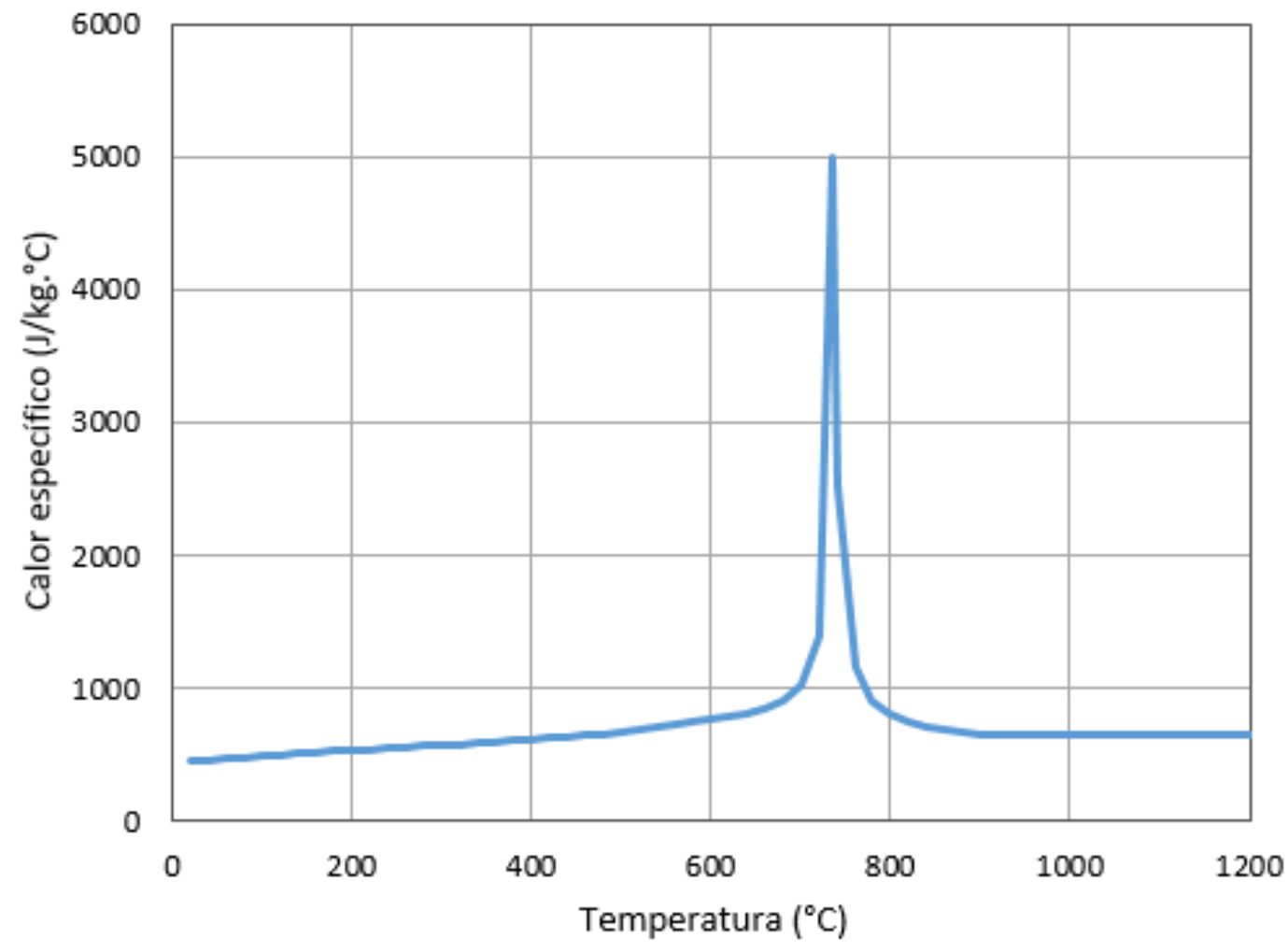

Figura 4.7- Gráfico Relação Calor Específico do aço x Temperatura

\subsubsection{Resultado e discussões - perfil metálico}

Na Figura 4.9 são apresentadas as curvas de temperatura por tempo de incêndio para os pontos de TX.1 a TX.6, indicados na Figura 4.8. Esses resultados foram obtidos por meio do programa de elementos finitos ABAQUS.

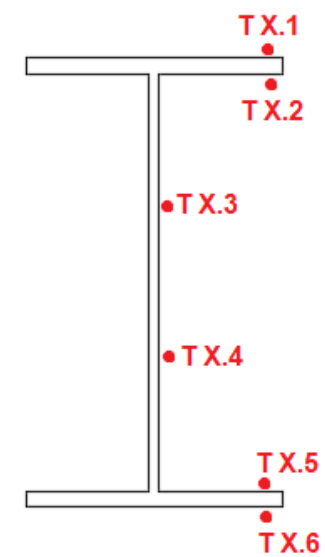

Figura 4.8- Pontos de análise na modelagem térmica no perfil metálico 


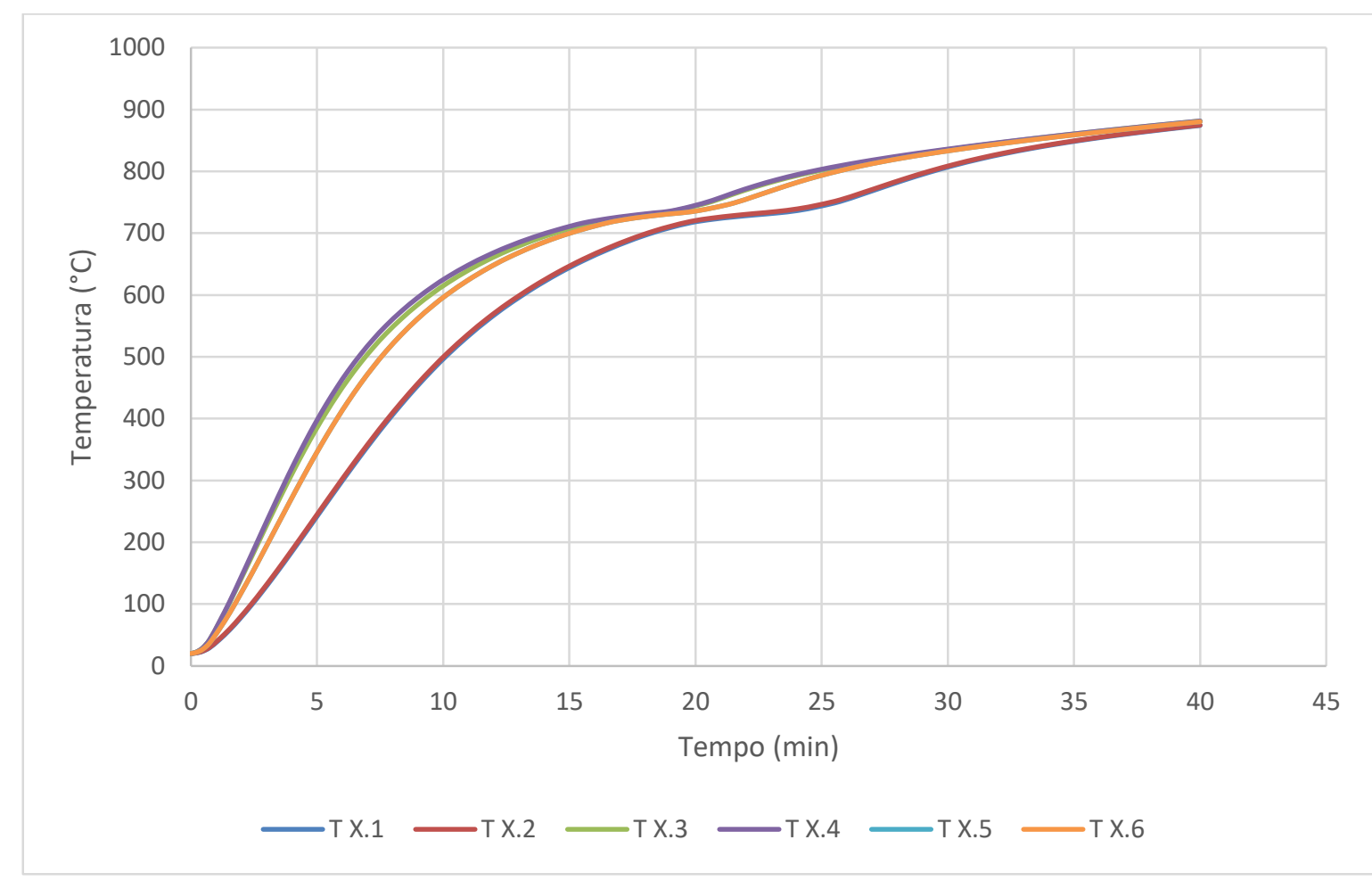

Figura 4.9 - Curvas de temperatura por tempo de incêndio

Ressalta-se que as análises numéricas, apresentadas na Figura 4.9 foram feitas para um tempo de incêndio de 40 minutos, entretanto a investigação experimental da viga metálica apresentada no tópico 2.6.2.2 desta dissertação durou aproximadamente 7 minutos.

A Tabela 4.2 apresenta um comparativo das temperaturas registradas através do ABAQUS nesta modelagem térmica com as temperaturas registradas na análise experimental que estão apresentadas na Figura 3.24 desta dissertação. Utilizaremos os dados da Seção 1 da análise experimental por possuir os dados mais completos e sem erro na medição.

Nota-se que houve boa concordância entre as temperaturas encontradas. Pela simulação numérica pode-se dizer que o ensaio experimental foi corretamente realizado, as leituras dos termopares foram feitas de forma correta e que o ensaio está a favor da segurança, uma vez que os valores das temperaturas medidos experimentalmente são sempre superiores aos valores encontrados numericamente. 
Outra constatação é a aplicabilidade do código computacional ABAQUS na análise térmica de vigas metálicas em situação de incêndio.

Tabela 4.2 - Comparativo das temperaturas entre análise térmica e experimental

\begin{tabular}{|c|c|c|c|}
\hline \multicolumn{4}{|c|}{$\begin{array}{c}\text { Temperaturas nos pontos de análise } \\
\text { em } 7 \text { minutos de incêndio }\end{array}$} \\
\hline & ABAQUS & Experimental & Erro (aprox.) \\
\hline T X.1 & $365^{\circ} \mathrm{C}$ & $281^{\circ} \mathrm{C}$ & $23 \%$ \\
\hline T X.2 & $370^{\circ} \mathrm{C}$ & $375^{\circ} \mathrm{C}$ & $1 \%$ \\
\hline T X.3 & $510^{\circ} \mathrm{C}$ & $530^{\circ} \mathrm{C}$ & $4 \%$ \\
\hline T X.4 & $530^{\circ} \mathrm{C}$ & $545^{\circ} \mathrm{C}$ & $3 \%$ \\
\hline T X.5 & $480^{\circ} \mathrm{C}$ & $530^{\circ} \mathrm{C}$ & $11 \%$ \\
\hline T X.6 & $480^{\circ} \mathrm{C}$ & $530^{\circ} \mathrm{C}$ & $11 \%$ \\
\hline
\end{tabular}

Na Figura 4.10 são apresentados três perfis de temperatura para a seção transversal do perfil metálico, obtido através do ABAQUS, onde é possível acompanhar a evolução da distribuição de temperatura ao longo do perfil ao longo do incêndio analisado. Os perfis correspondem a 2, 4 e 7 minutos de incêndio.

Os perfis de temperatura apresentam um gradiente térmico ao longo do perfil que é formado por faixas ao longo da altura do perfil da viga, sendo que essas faixas são mais espessas na parte inferior (mais quente) do que na região superior (mais frio). 


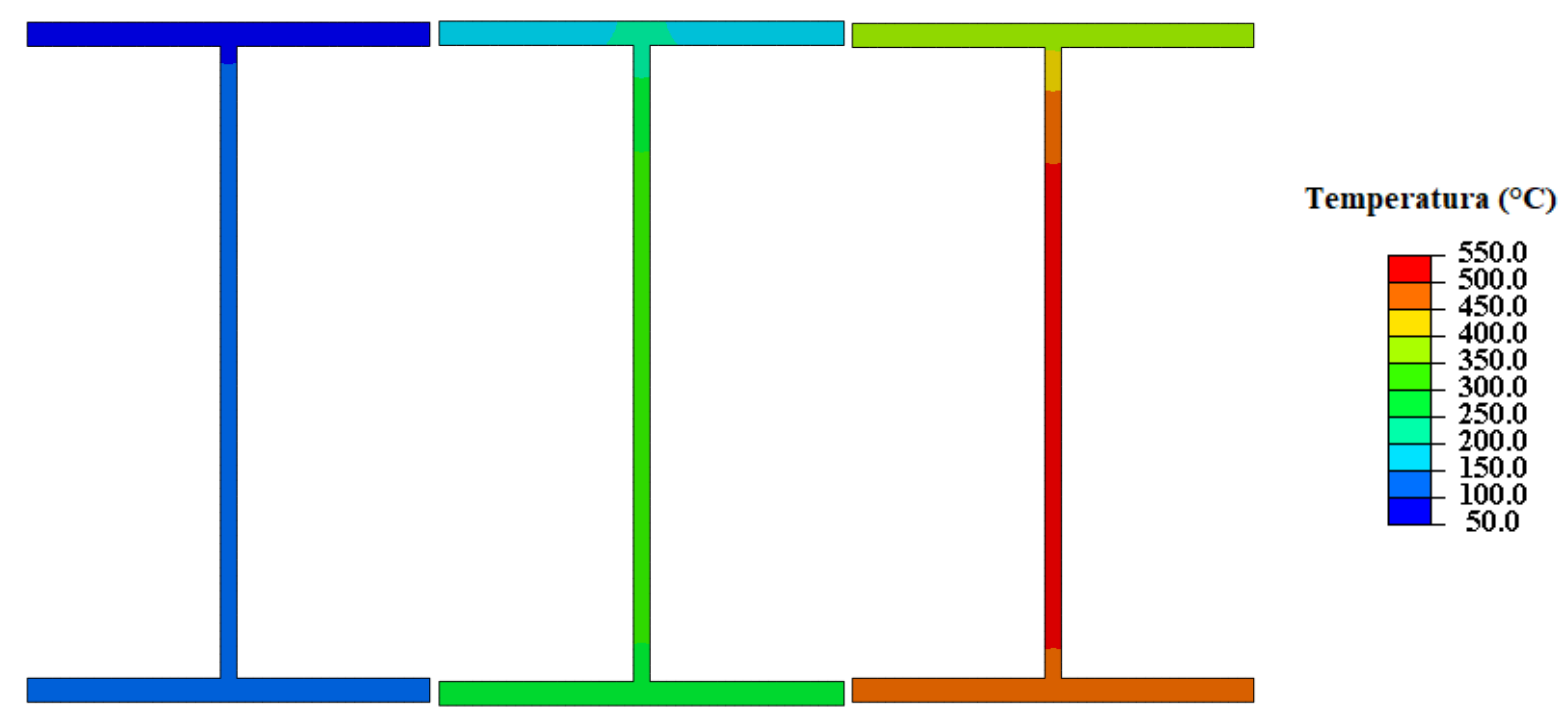

Figura 4.10 - Perfis de temperatura para a seção transversal do perfil metálico em 2, 4 e 7 minutos de ensaio respectivamente.

\subsubsection{Resultado e discussões - perfil misto}

$\mathrm{Na}$ Figura 4.12 são apresentadas as curvas de temperatura por tempo de incêndio para os pontos de TX.1 a T X.9, indicados na Figura 4.11. Os pontos T X.6 e T X.7 não aparecem no modelo numérico uma vez que eles se encontram na armadura do perfil misto de aço e concreto e foi feita uma análise bidimensional, impedindo de analisarmos esses pontos. O ponto T X.9 não aparece nas análises comparativas porque não temos dados experimentais sobre ele, houve erro na leitura desse termopar. Esses resultados foram obtidos por meio do programa de elementos finitos ABAQUS.

Ressalta-se que as análises numéricas, apresentadas na Figura 4.12 foram feitas para um tempo de incêndio de 30 minutos. Foram feitos três ensaios experimentais com as vigas mistas, como já foi descrito no Capítulo 3 desta dissertação, os tempos desses ensaios foram de 30, 28 e 23 minutos. Para comparações usaremos o ensaio experimental de maior duração (30 minutos). Esse ensaio está detalhado na seção 3.6.2.3 desta dissertação. 


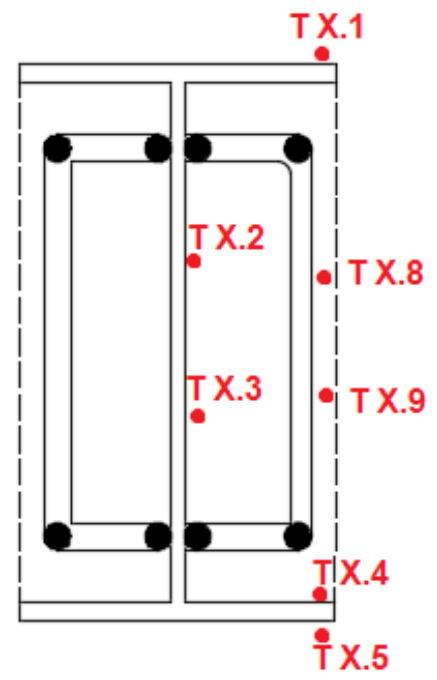

Figura 4.11 - Pontos de análise na modelagem térmica no perfil da viga mista.

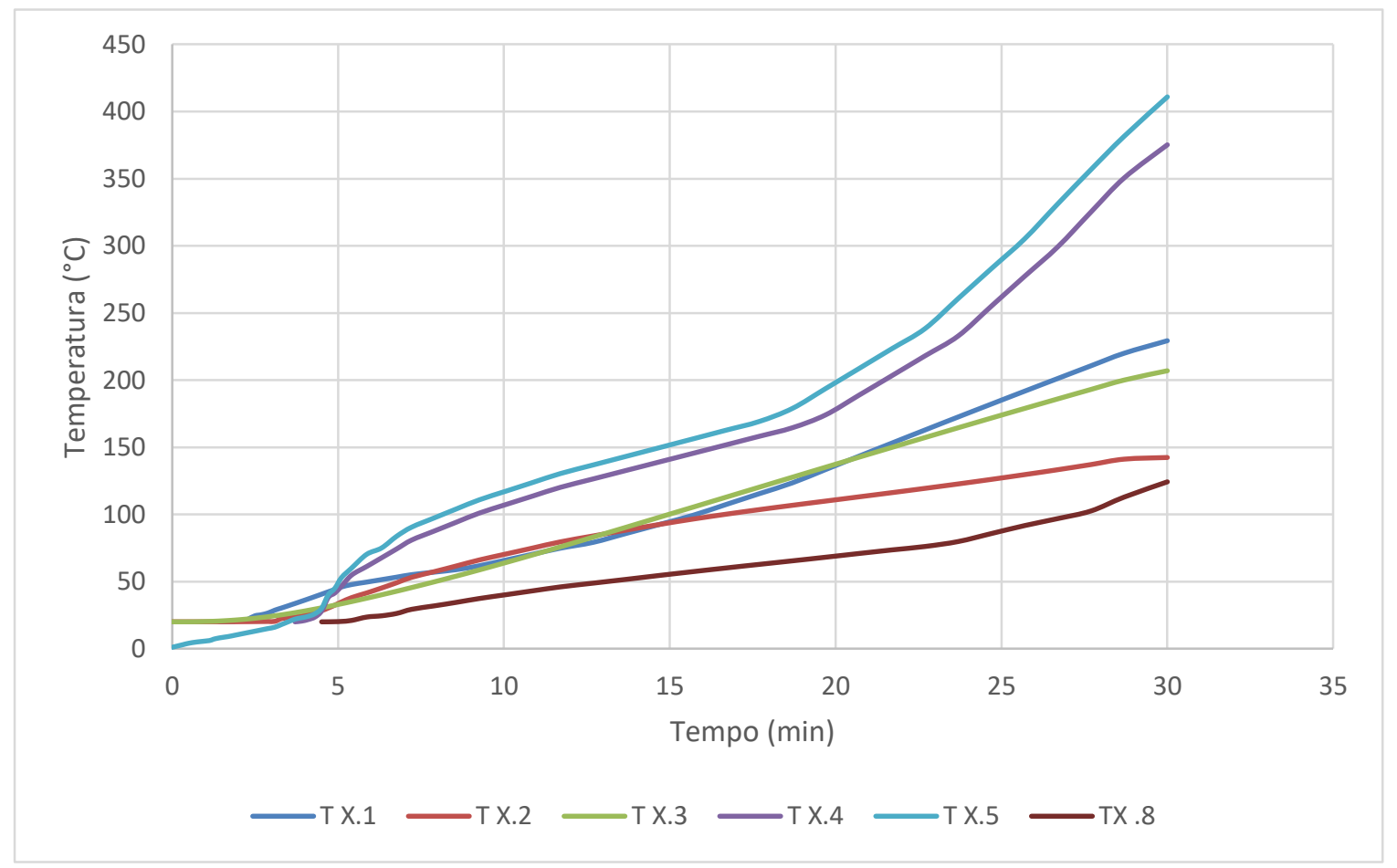

Figura 4.12 - Curvas de temperatura por tempo de incêndio

A Tabela 4.3 apresenta um comparativo das temperaturas registradas através do ABAQUS nesta modelagem térmica com as temperaturas registradas na análise experimental que estão apresentadas na Figura 3.26 desta dissertação. Utilizaremos 
os dados da Seção 2 da análise experimental por possuir os dados mais completos e sem muitos erros de leitura dos termopares.

Os pontos TX.2 e TX.8 tiveram uma maior diferença de temperaturas registradas entre as análises numérica e experimental. Os termopares responsáveis pela leitura da temperatura desses pontos foram colocados antes da concretagem da viga mista, logo, pode ter acontecido um dano na soldagem e a leitura no ensaio experimental ter sido comprometida. Nos demais pontos houve boa concordância entre as temperaturas encontradas. Pela simulação numérica pode-se dizer que o ensaio experimental foi corretamente realizado, as leituras dos termopares foram feitas de forma correta e que o ensaio está a favor da segurança, uma vez que os valores das temperaturas medidos experimentalmente são sempre superiores aos valores encontrados numericamente.

Mais uma vez podemos constatar a aplicabilidade do código computacional ABAQUS na análise térmica de vigas metálicas em situação de incêndio.

Na Figura 4.13 é apresentado um perfil de temperatura para a seção transversal do perfil da viga mista de aço e concreto, obtido através do ABAQUS, onde é possível ver a distribuição de temperatura ao longo do perfil para o incêndio de 30 minutos.

O perfil de temperatura apresenta um gradiente térmico ao longo do perfil que é formado por faixas ao longo da largura do perfil da viga, sendo que essas faixas são mais espessas na parte interna (mais fria) do que na região externa (mais quente). 
Tabela 4.3 - Comparativo das temperaturas entre análise térmica e experimental

\begin{tabular}{|c|c|c|c|}
\hline \multicolumn{4}{|c|}{ Temperaturas nos pontos de análise } \\
\hline & em 30 minutos de incêndio \\
\hline & $230^{\circ} \mathrm{C}$ & $240^{\circ} \mathrm{C}$ & $5 \%$ \\
\hline T X.1 & $145^{\circ} \mathrm{C}$ & $213^{\circ} \mathrm{C}$ & $46 \%$ \\
\hline T X.2 & $210^{\circ} \mathrm{C}$ & $235^{\circ} \mathrm{C}$ & $12 \%$ \\
\hline T X.3 & $375^{\circ} \mathrm{C}$ & $440^{\circ} \mathrm{C}$ & $7 \%$ \\
\hline T X.4 & $410^{\circ} \mathrm{C}$ & $425^{\circ} \mathrm{C}$ & $4 \%$ \\
\hline T X.5 & $125^{\circ} \mathrm{C}$ & $156^{\circ} \mathrm{C}$ & $24 \%$ \\
\hline T X.8 & & & \\
\hline
\end{tabular}

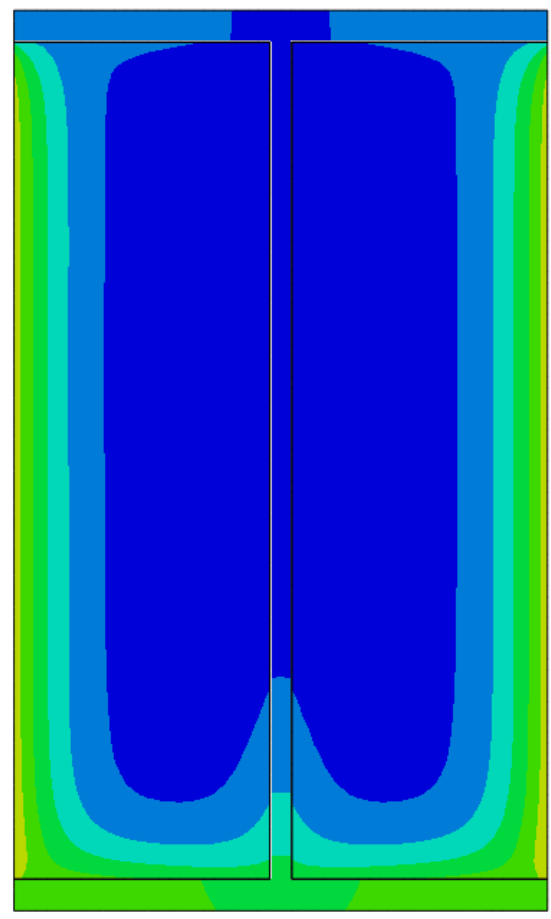

\section{Temperatura $\left({ }^{\circ} \mathrm{C}\right)$}

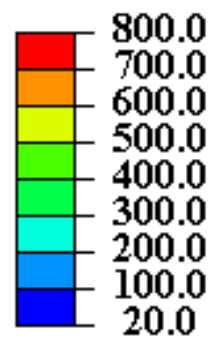

Figura 4.13 - Perfis de temperatura para a seção transversal do perfil da viga mista em 30 minutos de ensaio. 


\subsection{Análise dos deslocamentos nas vigas}

Neste tópico será apresentada de forma mais detalhada os deslocamentos registrados no programa experimental apresentado no capítulo 3 desta dissertação.

Para a viga metálica, a apresentação dos valores de deslocamento próximo aos apoios e no centro da viga é feita na Tabela 4.4. Ressaltando que esses valores que já foram apresentadas anteriormente nas Figuras 3.14 e Figura 3.23.

Tabela 4.4 - Valores de deslocamento na viga metálica

\begin{tabular}{|c|c|c|c|c|c|}
\hline \multirow{3}{*}{$\begin{array}{c}\text { Fator de } \\
\text { carga }\end{array}$} & \multirow{3}{*}{$\begin{array}{c}\text { Força } \\
(k N)\end{array}$} & \multicolumn{4}{|c|}{ Deslocamentos (mm) } \\
\hline & & \multicolumn{2}{|c|}{ Temperatura ambiente } & \multicolumn{2}{|c|}{ Altas temperaturas } \\
\hline & & Apoio & $\begin{array}{c}\text { Meio da } \\
\text { viga }\end{array}$ & Apoio & $\begin{array}{c}\text { Meio da } \\
\text { viga }\end{array}$ \\
\hline $30 \%$ & 37,65 & 0,7 & 11 & 20 & 93 \\
\hline
\end{tabular}

De acordo com os dados apresentados na Tabela 4.4, nota-se que, para 0 mesmo fator de carga, o deslocamento em altas temperaturas é cerca de 28 vezes maior do que em temperatura ambiente. Esse grande deslocamento em altas temperaturas foi observado durante o ensaio, uma vez que houve grande rotação nos apoios, sendo esse um dos motivos para finalizar o ensaio. Já no centro da viga, vale ressaltar que os valores apresentados para altas temperaturas é um deslocamento médio de dois transdutores que foram colocados na seção central da viga. $O$ deslocamento no centro da viga em altas temperaturas foi aproximadamente 8 vezes maior que o mesmo deslocamento medido em temperatura ambiente.

Comprova-se então a influência de temperaturas elevadas no comportamento da viga metálica, uma vez que o único fator variante entre os dois ensaios foi esse (o fator de carga foi o mesmo). 
A Tabela 4.5 apresenta os deslocamentos para as vigas mistas de aço e concreto que foram ensaiadas, tanto em temperatura ambiente, quanto em altas temperaturas. Foram 3 ensaios com vigas mistas, sendo dois com o mesmo fator de carga $(30 \%)$ e o outro com fator de carga de $45 \%$. Os valores da tabela já foram apresentados anteriormente nas Figuras 3.16, 3.25 e 3.29 .

Tabela 4.5 - Valores de deslocamento na viga mista de aço e concreto

\begin{tabular}{|c|c|c|c|c|c|}
\hline \multirow{3}{*}{$\begin{array}{c}\text { Fator de } \\
\text { carga }\end{array}$} & \multirow{3}{*}{$\begin{array}{l}\text { Força } \\
\text { (kN) }\end{array}$} & \multicolumn{4}{|c|}{ Deslocamentos (mm) } \\
\hline & & \multicolumn{2}{|c|}{ Temperatura ambiente } & \multicolumn{2}{|c|}{ Altas temperaturas } \\
\hline & & Apoio & $\begin{array}{c}\text { Meio da } \\
\text { viga }\end{array}$ & Apoio & $\begin{array}{c}\text { Meio da } \\
\text { viga }\end{array}$ \\
\hline $30 \%$ & 48,24 & 0,9 & 12 & 14 & 42 \\
\hline $30 \%$ & 48,24 & 0,9 & 12 & 14 & 52 \\
\hline $45 \%$ & 72,36 & 1,4 & 17 & 15 & - \\
\hline
\end{tabular}

Pelos dados da Tabela 4.5, observamos que para o mesmo fator de carga, os deslocamentos foram semelhantes, o que já era esperado. Nesses ensaios, o deslocamento em altas temperaturas próximo aos apoios foi aproximadamente 16 vezes maior que o deslocamento em temperatura ambiente. Já no meio da viga, o deslocamento em altas temperaturas foi cerca de 3 a 4 vezes maior que o deslocamento em temperatura ambiente.

Se compararmos agora os deslocamentos dos ensaios com variação do fator de carga encontramos deslocamentos maiores para fator de carga de $45 \%$ em relação aos de fator de carga de $30 \%$. Já era um resultado esperado uma vez que quanto maior a carga aplicada na viga maiores os deslocamentos dela.

No ensaio com fator de carga de $45 \%$ temos que o deslocamento em altas temperaturas próximo aos apoios aumentou cerca de 11 vezes se comparado ao deslocamento em temperatura ambiente. Não podemos fazer a mesma comparação 
com os deslocamentos do meio da viga pois os transdutores que mediam esse deslocamento em altas temperaturas se rompeu durante o ensaio, impossibilitando assim de termos uma leitura.

Com os dados apresentados, comprova-se a influência de temperaturas elevadas no comportamento da viga mista de aço e concreto, aumentando seus deslocamentos quando comparado aos deslocamentos em temperatura ambiente.

\subsection{Análise dos ensaios em temperaturas elevadas com o mesmo fator de carga}

No programa experimental apresentado no Capítulo 3 desta dissertação, foi feito dois ensaios com em altas temperaturas com o mesmo fator de carga. A repetição desse ensaio teve como finalidade a comprovação dos resultados e do método utilizado, uma vez que foram os primeiros ensaios em altas temperaturas e havia falta de experiência.

O primeiro ensaio teve duração de 30 minutos e teve uma taxa de deslocamento de $1,7 \mathrm{~mm} / \mathrm{min}$. Houve ruptura de um dos cabos dos transdutores que fazia a medição do deslocamento no meio da viga. Houve também um ponto de leitura de temperatura perdido (T1.2).

O segundo ensaio teve duração de 28 minutos, com uma taxa de deslocamento de $1,55 \mathrm{~mm} / \mathrm{min}$. Não houve ruptura de nenhum cabo dos transdutores que mediram os deslocamentos, porém mais pontos de leitura de temperatura foram perdidos (T1.1, T1.4 e T1.8.

Os resultados encontrados mostram que de certa forma o método de ensaio é eficiente, e foi importante a realização de mais de um ensaio, pois os dados que acabaram perdidos em um estão presentes no outro. Vale ressaltar a necessidade de melhorar a soldagem dos termopares nos pontos onde se deseja medir a temperatura além de um melhor esquema de como colocar os cabos transdutores para eles não se romperem perdendo assim as medidas de deslocamento na viga. 


\subsection{Comparação com a pesquisa de Piloto}

Piloto (2013) apresenta um trabalho apenas com vigas mistas de aço e concreto parcialmente revestidas em altas temperaturas. Ele fez ensaios experimentais em tamanho reduzido, com todas as faces da viga expostas ao fogo. Ele utilizou reforços na viga e aplicou três níveis de carga em seus ensaios (37\%,56\% e $74 \%$ ). No programa experimental desta dissertação foram aplicados dois fatores de carga $(30 \%$ e $40 \%)$ nos ensaios em altas temperaturas em escala real.

Ele concluiu com seu trabalho que existe uma dependência da resistência ao fogo com o nível de carga aplicado. Foram observadas fissuras e desplacamento no concreto durante os ensaios, o que também ocorreu nos ensaios em escala real.

Ele ressalta que as conclusões sobre esses ensaios por ele realizado só podem ser tiradas para o tipo de seção transversal escolhida e com o tamanho reduzido do elemento.

Em relação a temperaturas obtidas, apesar de ter todas as faces expostas ao fogo e a presença de reforços, uma comparação pode ser feita com os resultados de escala reduzida e os de escala real.

Para o fator de carga aproximado de $30 \%$, as maiores temperaturas foram encontradas na mesa inferior e em um ponto externo ao concreto, com temperaturas em torno de $650^{\circ} \mathrm{C}$. Já as menores temperaturas, ficaram na casa dos $400^{\circ} \mathrm{C}$ e foram registradas nas armaduras, alma, e um ponto interno no concreto. Para esse mesmo fator de carga, em escala real, os resultados encontrados pelo programa experimental desta dissertação foi de maiores temperaturas presente na mesa inferior, na casa dos $400^{\circ} \mathrm{C}$, e temperaturas mais baixas no restante do perfil em trono de $200^{\circ} \mathrm{C}$. Lembrando que essas temperaturas foram registradas com o mesmo tempo de incêndio, 30 minutos.

Ressalta-se que essa diferença nas temperaturas entre escala real e reduzida pode ser justificada por em um todas as faces estarem expostas ao fogo e no outro uma face permanece em temperatura ambiente, além dos reforços que foram utilizados nos ensaios de escala reduzida e não foram empregados nos ensaios em escala real. 
Não foi possível fazer uma comparação com os demais fatores de carga, uma vez que eles diferem muito nos ensaios de escala reduzida e escala real. 


\section{Capítulo 5}

\section{CONCLUSÕES}

Após a finalização desse trabalho, pode-se concluir que para uma mesma carga aplicada foi observado deslocamentos muito mais expressivos nos ensaios das vigas em situação de incêndio se comparados aos valores obtidos nos ensaios à temperatura ambiente.

Observou-se também que, como os deslocamentos foram muito mais expressivos em situação de incêndio, altas temperaturas comprometem as propriedades térmicas e mecânicas dos materiais, culminando assim no comprometimento da capacidade resistente desses materiais.

Verificou-se o efeito benéfico do revestimento de concreto ao perfil metálico, responsável por um ganho expressivo de resistência ao fogo quando comparado aos elementos puramente metálicos.

Os ensaios permitiram significativo ganho de experiência a todos participantes, sejam eles alunos da graduação ou do mestrado, professores e técnicos de laboratório, uma vez que esses tipos de ensaio são inovadores no Brasil. Destaca-se também que dificuldades foram encontradas, como perda na leitura de temperatura e/ou deslocamentos.

Esses ensaios servirão como ponto de partida para as demais pesquisas que serão desenvolvidas no forno do laboratório de estruturas da EESC/USP. 
Comparando-se os valores de carga máxima resistente das vigas metálicas e mistas de aço e concreto parcialmente revestidas encontradas experimentalmente através de ensaios em temperatura ambiente e seus valores teóricos calculados, para as vigas metálicas houve boa precisão, sendo o valor experimental aproximadamente $8 \%$ maior que o teórico. Já para a viga mista de aço e concreto o valor experimental apresentou-se cerca de $11 \%$ maior que o teórico. Esse valor comparativo pode ser explicado por falhas nos ensaios, sejam elas na montagem do experimento ou na aplicação da carga na viga.

Nota-se que houve boa concordância entre as temperaturas encontradas por modelagem numérica através do ABAQUS e dos ensaios experimentais realizados, tanto para o perfil metálico quanto para o perfil de viga mista de aço e concreto parcialmente revestidas. Pela simulação numérica pode-se dizer que o ensaio experimental foi corretamente realizado, as leituras dos termopares foram feitas de forma correta e que o ensaio está a favor da segurança, uma vez que os valores das temperaturas medidos experimentalmente são sempre superiores aos valores encontrados numericamente. Outra constatação é a aplicabilidade do código computacional ABAQUS na análise térmica de vigas metálicas e mistas de aço e concreto parcialmente revestidas em situação de incêndio.

Quando comparado os deslocamentos dos ensaios com variação do fator de carga encontramos deslocamentos maiores para fator de carga de $45 \%$ em relação aos de fator de carga de $30 \%$. Já era um resultado esperado uma vez que quanto maior a carga aplicada na viga maiores os deslocamentos dela.

A repetição de ensaios com as mesmas características e fator de carga em altas temperaturas geram resultados que mostram que o método de ensaio é eficiente. Foi importante a realização de mais de um ensaio, pois os dados que acabaram perdidos em um estão presentes no outro. Vale ressaltar a necessidade de melhorar a soldagem dos termopares nos pontos onde se deseja medir a temperatura além de um melhor esquema de como colocar os cabos transdutores para eles não se romperem perdendo assim as medidas de deslocamento na viga.

Em comparação do presente trabalho com o trabalho de Piloto em escala reduzida encontramos valores de temperatura que se distanciam um pouco. Esse fato 
pode ser explicado pelo fato do ensaio em escala reduzida todas as faces da viga estão em contato com altas temperaturas, o que não acontece em escala real, além do uso de reforços em escala reduzida que não foram empregados em escala real.

Nos ensaios de escala reduzida houve a presença de fissuras visíveis e desplacamento do concreto, características que também foram constatadas em ensaios de escala real, portanto alguns comportamentos das vigas podem ser previstos ou analisados em escala reduzida, não sendo necessário o uso de ensaios em escala real.

\subsection{Sugestões para trabalhos futuros}

Faz-se necessário a realização de uma análise experimental de vigas mistas de aço e concreto parcialmente revestidas em situação de incêndio. Dados desse presente trabalho podem ser utilizados para calibração do modelo numérico.

Mais trabalhos experimentais, em escala real, precisam ser feitos em altas temperaturas no Brasil. Dificuldades que foram encontradas nesse presente trabalho devem ser utilizadas como exemplo e ponto de partida para que a cada trabalho feito no forno a gás seja mais fiel à teoria.

Podem ser realizados trabalhos que estudem outras formas de proteção de estruturas puramente metálicas, como, por exemplo, utilizando tintas de proteção térmica. 


\section{REFERÊNCIAS BIBLIOGRÁFICAS}

ABAQUS (2014) - ABAQUS/CAE User's Manual, Dassault Systèmes, Providence, USA.

ASSOCIAÇÃO BRASILEIRA DE NORMAS TÉCNICAS (2008). NBR 8800: Projeto de estruturas de aço e de estruturas mistas de aço e concreto de edifícios. Rio de Janeiro: ABNT.

(2013). NBR 14323 - Dimensionamento de estruturas de aço de edifícios em situação de incêndio - Procedimento. Rio de Janeiro: ABNT.

(2014). NBR 6118 - Projeto de estruturas de concreto - Procedimento. Rio de Janeiro: ABNT.

(2013). NBR 6892 - Materiais e métodos - Ensaio de tração. Rio de Janeiro: ABNT.

(2007). NBR 5739 - Concreto - Ensaios de compressão de corpos de prova cilíndricos. Rio de Janeiro: ABNT.

BAILEY, C.G. (1999). Behaviour of asymmetric slim floor steel beams in fire. Journal of Constructional Steel Research 50, 235-257.

BUCHANAN, A. H. (2002). Structural Design for Fire Safety. Chichester: John Wiley \& Sons, Ltd.

CAVALCANTI, L.A. (2010). Estudo teórico-experimental da contribuição de armadura para a capacidade resistente de vigas parcialmente revestida. Dissertação 
(Mestrado) - Escola de Engenharia de São Carlos, Universidade de São Paulo, São Carlos.

CHOI, S., ALI, F., NADJAI, A., HAN, S., AND CHOI, J. (2011). Structural performance of slim beam floor system in fire. Journal of Structural Fire Engineering 2, 57-66.

COSTA, C.N.; SILVA, V.P. (2006) Revisão histórica das curvas padronizadas de incêndio. In: Seminário Internacional NUTAU'06 Tecnologia e Durabilidade, 2006, São Paulo. Nutau'06. São Paulo: Núcleo de Tecnologia em Arquitetura e Urbanismo da Universidade de São Paulo.

DE NARDIN, S. (1999). Estudo teórico-experimental de pilares mistos compostos por tubos de aço preenchidos com concreto de alta resistência, Dissertação (Mestrado) - Escola de Engenharia de São Carlos, Universidade de São Paulo, São Carlos.

DE NARDIN, S., AND EL DEBS, A.L.H.C. (2009). Study of partially encased composite beams with innovative position of stub bolts. Journal of Constructional Steel Research 342-350.

DE NARDIN, S., AND EL DEBS, A.L.H.C. (2012). Composite connections in slimfloor system: An experimental study. Journal of Constructional Steel Research 68, 78-88.

DONG, Y., AND PRASAD, K. (2009). Behavior of full-scale frames with slim floor slab construction under exposure in a fire resistance furnace. Journal of Fire Protection Engineering 19, 197-220.

ELLOBODY, E. (2012). Composite slim floor stainless steel beam construction exposed to different fires. Engineering Structures 36, 1-13.

EUROPEAN COMMITTEE FOR STANDARDIZATION (2005). EN 1991-1-2: Eurocode 1 - Basis of design and actions on structures. Part 1-2: Actions on structures - Actions on structures exposed to fire, final draft, Brussels.

(2005). EN 1994-1-1:2005 Eurocode 4-Design of composite steel and concrete structures. Part 1-2: General rules - Structural Fire Design. Brussels. 
FAKURY, R.H. (1999) Dimensionamento de estruturas de aço de edifícios em situação de incêndio. Trabalho produzido especialmente para o núcleo de excelência em estruturas metálicas e mistas. Vitória.

FIGUEIREDO, L.M.B. (1998). Projeto de construção de pilares mistos aço-concreto. Dissertação (Mestrado) - Escola de Engenharia de São Carlos, Universidade de São Paulo, São Carlos.

HOSSER, D., DORN, T., AND EL-NESR, O. (1994). Experimental and Numerical Studies of Composite Beams Exposed to Fire. Journal of Structures Engineering 120, 22.

KIM, H.J., KIM, H.J., AND PARK, S.Y. (2011). An experimental study on fire resistance of slim floor beam. In 3rd International Workshop on Performance, Protection and Strengthening of Structures under Extreme Loading, PROTECT2011, August 30, 2011 - September 1,2011, (Trans Tech Publications), pp. 752-757.

KINDMANN, R., AND BERGMANN, R. (1993). Effect of reinforced concrete between the flanges of the steel profile of partially encased composite beams. Journal of Constructional Steel Research 27, 107-122.

KODAIRA, A., FUJINAKA, H., OHASHI, HG., AND NISHIMURA, T. (2004). Fire Resistance of Composite Beams Composed of Rolled Steel Profile Concreted Between Flanges. Fire Science and Technology 23, 192-208.

KODUR, V.K.R., GARLOCK, M., AND IWANKIW, N.(2012). Structures in Fire: Stateof-the-Art, Research and Training Needs. Fire Technology 48, 825-839.

LAWSON, R.M., MULLET, D.L., RACKHAM, J.W. (1997). Design of asymmetric "Slim floor" beams using deep composite decking, Steel Construction Institute, SCI P-179.

MA, Z., AND MAKELAINEM, P. (2000). Behavior of composite slim floor structures in fire. Journal of Structural Engineering New York, N.Y. 126, 830-837.

MA, Z., AND MAKELAINEM, P. (2006). Structural behaviour of composite slim floor frames in fire conditions. Journal of Constructional Steel Research 62, 1282-1289. 
MAKELAINEM, P., AND MA, Z. (2000). Fire resistance of composite slim floor beams. Journal of Constructional Steel Research 54, 345-363.

MALITE, M. (1993). Análise de comportamento estrutural de vigas mistas açoconcreto constituídas por perfis de chapa dobrada. São Carlos. 2v. Tese (Doutorado) - Escola de Engenharia de São Carlos. Universidade de São Paulo.

MARAVEAS, C.M., SWAILES, T., AND WANG, Y. (2012). A Detailed Methodology for the Finite Element Analysis os Assymetric Slim Floor Beams in Fire. In Proceedings of the 2012 Nordic Steel Construction Conference, (Oslo, Norway).

MENDES, C. L. (2004) Estudo teórico dobre perfis formados a frio em situação de incêndio. 160 p. Dissertação de Mestrado - Escola de Engenharia de São Carlos, Universidade de São Paulo, São Carlos.

NEWMAN, G.M. (1995). Fire Resistance of Slim Floor Beams. Journal of Constructional Steel Research 33, 87-100.

NAKAMURA, S., AND NARITA, N. (2003). Bending and shear strengths of partially encased composite I-girders. Journal of Constructional Steel Research 59, 14351453.

PAES, J.L.R. (2003). Aportaciones al análisis del comportamiento estructural de sistemas de forjados mixtos tipo "Slim floor". Departamento de Engenharia de Construção, Universidade Politécnica da Catalunha, Barcelona.

PARK, S., KIM, H., AND HONG, K.(2013). Effect of Load Rations on the Behavior of Asymmetric Slim Floor Beams Exposed to Fire. Fire Technology 49, 907-926.

PILOTO, P.A.G., GAVILA, A.B.R., ZIPPONI, M., MARINI, A., MESQUITA, L.M.R., AND PLIZZARI, G. (2013). Experimental investigation of the fire resistance of partially encased beams. Journal of Constructional Steel Research 80, 121-137. PURKIS, J.A. (2007). Fire Safety Engineering - Design of Structures. Second Edition. Butterworth-Heinemann: 1-13.

QUEIROZ, G., PIMENTA,R.J., MARTINS, A.G. (2010). Manual de construção em aço- Estruturas Mistas. 2v. Centro Brasileiro de Construção em Aço - CBCA, Rio de Janeiro. 
RIBEIRO, J. C. L. (2004) Simulação via método dos elementos finitos da distribuição tridimensional de temperatura em estruturas em situação de incêndio. 178 p.

Dissertação de Mestrado - Escola de Engenharia da Universidade Federal de Minas Gerais, Universidade Federal de Minas Gerais, Belo Horizonte.

REGOBELLO, R. (2007) Análise numérica de seções transversais e de elementos estruturais de aço e mistos de aço e concreto em situação de incêndio. 254 p. Dissertação de Mestrado - Escola de Engenharia de São Carlos, Universidade de São Paulo, São Carlos.

ROCHA, F.M. (2012). Modelos numéricos de vigas mistas de aço e concreto pertencentes a sistemas de pisos mistos de pequena altura em situação de incêndio. Dissertação (Mestrado) - Escola de Engenharia de São Carlos, Universidade de São Paulo, São Carlos.

SCHAUMANN, P., AND HOTHAN, S.(2002). Fire Design of a new slim floor beams system using FEM-Analysis. (Christchurch), pp. 291-302.

SILVA, C.J., CALMON, J.L. (2001). Análise térmica bidimensional em regime transiente pelo método dos elementos finitos. Aplicação às estruturas de concreto de alto desempenho. Revista Engenharia Ciência Tecnologia. Vitória.

VELARDE, J.L.S. (2008). Sobre o comportamento dos pilares de aço em situação de incêndio. São Carlos. Dissertação (Mestrado) - Escola Politécnica - Universidade de São Paulo.

VILA REAL, P. (2003). Incêndio em Estruturas Metálicas - Cálculo Estrutural. Edições Orion. Mafra.

WANG, Y.C. (2002). Steel and Composite Structures - Behaviour and Design for Fire Safety. Spon Press. London.

WANG, Y., YANG, L., SHI, Y., AND WANG, C. (2012). Pseudo-static loading test on a full-scale two-storey composite slim floor. Tumu Gongcheng Xuebao/China Civil Engineering Journal 45,26-34+98. 
WENG, C.C., YEN, S.I., AND JIAG, M.H. (2002) Experimental study on shear splitting failure of full-scale composite concrete encased steel beams. Journal of Structural Egineering 128, 1186-1194. 


\section{Apêndice A}

\section{CARACTERIZAÇÃO DO INCÊNDIO}

\section{A.1 Conceitos gerais sobre incêndio}

Segundo Silva et al. (2010), o fogo é um fenômeno físico-químico, caracterizado por uma reação de oxidação, com emissão de calor e luz. Para que ocorra a combustão devem coexistir os seguintes componentes:

- Combustível: substância que por meio de reação química da combustão é capaz de produzir calor;

- Comburente: o oxigênio é o mais comum, mas pode ser qualquer substância que alimenta a reação química da combustão;

- Calor: energia térmica que se transfere de um sistema para outro em virtude da diferença de temperatura entre os dois;

- Reação em cadeia: a sequência dos três eventos acima, que resulta na combustão propriamente dita. Esses três eventos são mostrados no triângulo do fogo da Figura A.1. 


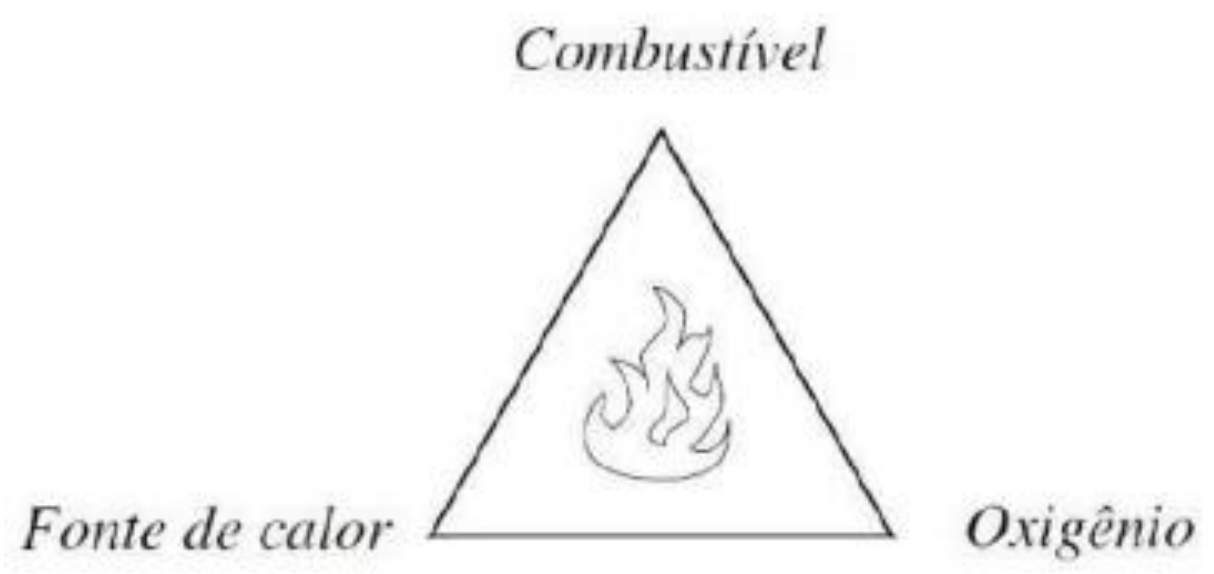

Figura A.1 - Triângulo do fogo

Fonte: Caldas (2008)

Ao serem aquecidos, vapores dos combustíveis se desprendem da superfície do sólido e se misturam ao oxigênio do ar. Essa mistura inflamável que se forma é a responsável pela ignição. Apareça uma chama na superfície do sólido combustível. Este fornece mais vapor combustível para a queima gerando assim um ciclo que só para quando um dos elementos (combustível, comburente ou calor) for eliminado.

\section{A.2 Desenvolvimento do incêndio}

A evolução de um incêndio passa por três fases bem definidas: fase inicial de elevação progressiva da temperatura; fase de aquecimento brusco e fase de resfriamento e extinção. Todas as fases estão representadas na Figura A.2

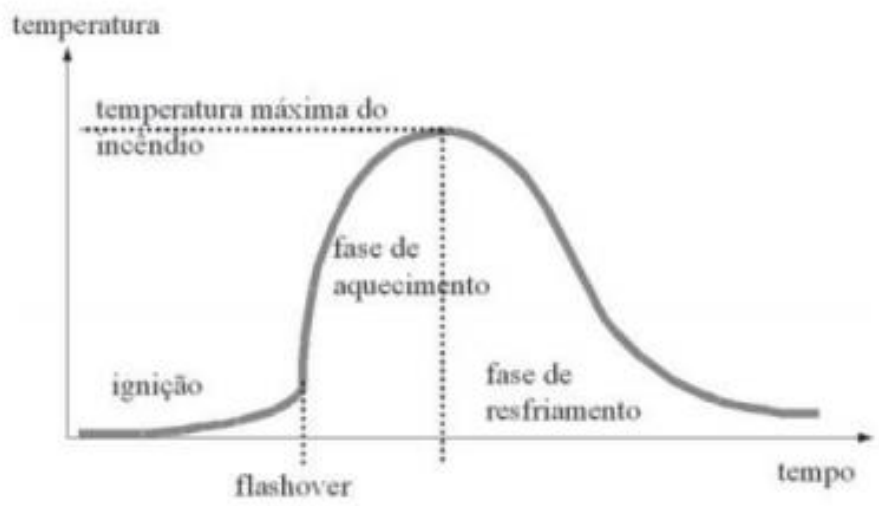

Figura A.2 - Curva temperatura-tempo de um incêndio real

Fonte: Silva et al. (2010) 
A fase inicial do aumento da temperatura se caracteriza pelo surgimento da ignição inicial. Nesta fase, a combustão pode gerar gases tóxicos, mas, o risco de dano à estrutura é pequeno. $O$ incêndio começa então a se espalhar lentamente e uma quantidade significativa de fumaça e gases inflamáveis é produzida, indicando o período de pré-flashover. $O$ flashover é o ponto de transição para o período de combustão mais forte, demonstrado no gráfico da Figura A.2 pelo ponto onde se aumenta a inclinação. Esse período é chamado de combustão generalizada, onde as temperaturas no ambiente são elevadas e as taxas de produção de calor são muito altas (Buchanan, 2001). Após algum tempo, devido ao total consumo do combustível presente no local ou à falta de oxigênio, o incêndio terá sua intensidade reduzida, entrando na fase de resfriamento e, em seguida, extinguir-se-á.

\section{A.3 Incêndio-padrão}

A caracterização de um incêndio por meio de curvas tempo-temperatura nem sempre é possível, uma vez que há uma gama de parâmetros que nele influem. Os primeiros ensaios de resistência ao fogo de elementos estruturais, realizados nos Estados Unidos no início do século XX, levaram a uma curva tempo-temperatura característica conhecida como incêndio-padrão. Nesse modelo de incêndio se admite que a temperatura dos gases do ambiente em chamas segue as curvas padronizadas para ensaios. Embora não represente o desenvolvimento de um incêndio real, convencionou-se adotar a curva de incêndio-padrão como modelo para análise experimental de estruturas, de materiais de revestimento contra fogo, de portas cortafogo, etc. Segundo Silva (1997), a característica principal dessa família de curvas é a de possuir apenas um ramo ascendente, admitindo, portanto, que a temperatura dos gases é sempre crescente com o tempo.

O EN 1991-1-2 (2002) e as normas brasileiras ABNT NBR 5628:1980 e ABNT NBR 14432:2000 recomendam a aplicação da curva de incêndio-padrão fornecida pela ISO 834 (1975). De acordo com Costa e Silva (2006), em 1961, a Organisation for International Standards designou um comitê para preparar um compêndio de especificações para ensaios de resistência ao fogo; os estudos deram origem ao texto R834 para discussão - era a primeira versão do projeto de uma norma, que propunha 
uma curva temperatura-tempo, resultante da uniformização entre as curvas americanas ASTM E119 (1918) e britânica BS476 (1932). Em 1975, essa organização publicou a norma ISO 834 "Fire-Resistance Tests - Elements of Building Construction", que forneceu a Equação A.1 para estimar a temperatura em função do tempo. O gráfico da curva de incêndio-padrão ISO 834:1975 é ilustrado na Figura A.3.

$$
\theta g=\theta_{0}+345 \cdot \log (8 t+1)
$$

Onde,

$\theta g$ é a temperatura dos gases, em graus Celsius, no instante $t$;

$\theta_{0}$ é a temperatura do ambiente antes do início do aquecimento, em graus Celsius, geralmente tomada igual a $20^{\circ} \mathrm{C}$;

$t$ é o tempo, em minutos.

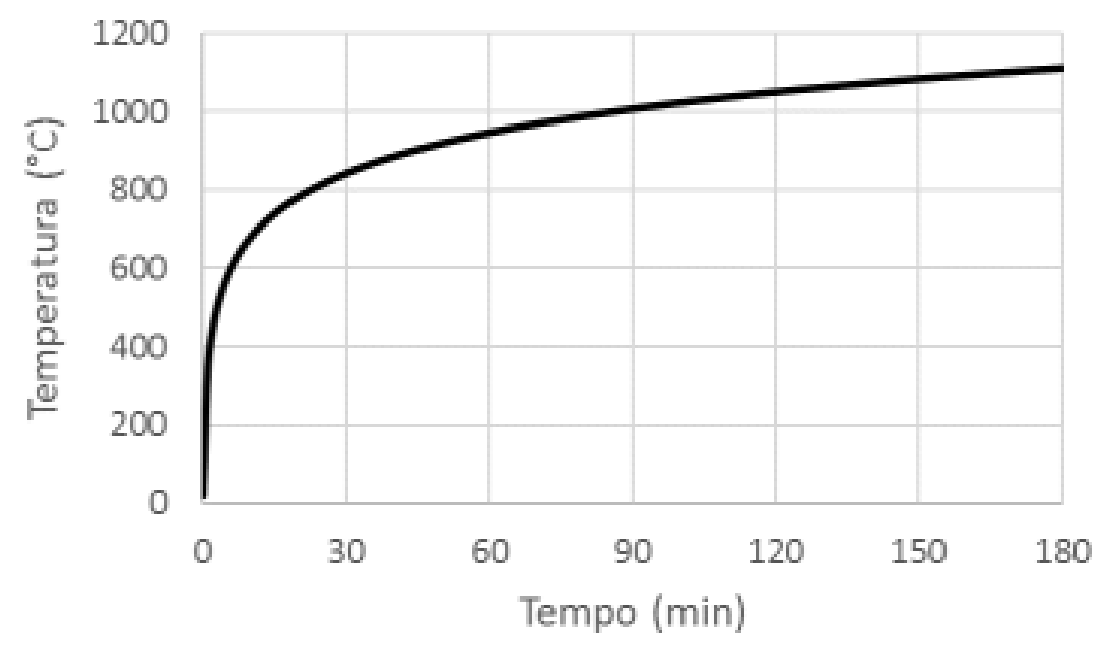

Figura A.3 - Curva de incêndio-padrão

Fonte: ISO 834:1975 


\section{A.4 Incêndio natural}

É denominado incêndio natural aquele em que se admite que a temperatura dos gases respeite as curvas temperatura-tempo naturais, cuja construção é realizada a partir de ensaios, modelos matemáticos aferidos em ensaios ou de incêndios que simulem a real situação de um compartimento em chamas. Os ensaios acontecem em compartimentos com aberturas (janelas), nos quais 0 incêndio ocorre sem possibilidade de propagação para fora dos mesmos. Isso é possível devido às características apresentadas pelo compartimento, como isolamento térmico, estanqueidade e resistência dos elementos de vedação. A principal característica que difere as curvas de incêndio natural das curvas de incêndio-padrão é a de possuir um ramo ascendente (fase de aquecimento) e um ramo descendente (fase de resfriamento) admitindo, portanto, racionalmente, que as fases que envolvem o fogo não têm sua temperatura sempre crescente com o tempo, conforme a Figura A.4.

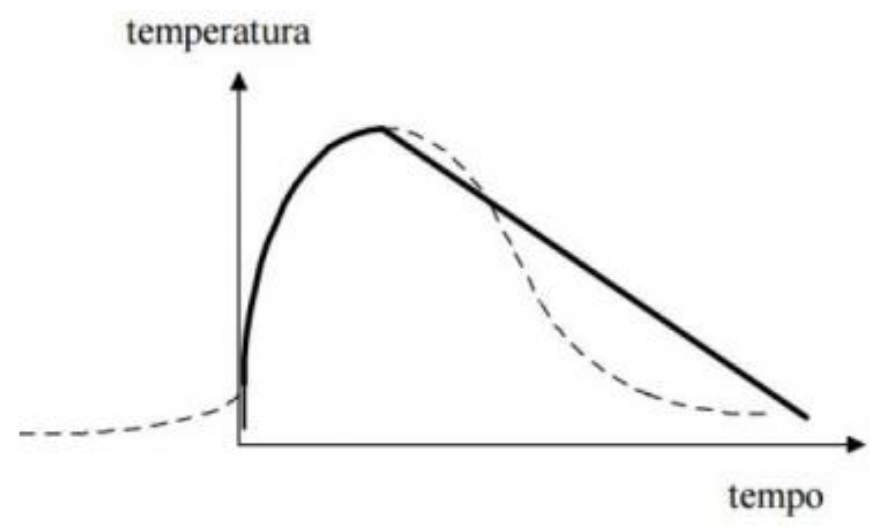

Figura A.4 - Curva de incêndio natural

Fonte: Silva (1997)

\section{A.5 Medidas de Proteção}

No combate a situações de incêndio as formas de proteção adotadas têm como principais objetivos:

- Proteção da vida dos ocupantes;

- Dificultar a propagação do incêndio ou extingui-lo no seu estágio inicial; 
- Fornecer condições para a execução das operações de combate do corpo de bombeiros e reduzir a perda de patrimônio;

Dentro do contexto de proteção, a ABNT NBR 14432:2001 faz a classificação em dois tipos distintos: a proteção ativa e a proteção passiva.

A proteção ativa contra incêndio consiste nos meios que necessitam ser ativados de forma manual ou automática em resposta aos estímulos provocados pelo fogo. Esta proteção objetiva a detecção rápida do incêndio para que os ocupantes sejam alertados e retirados em segurança da edificação. São compostas, basicamente, pelas instalações prediais de proteção contra incêndio. Podem ser citados como exemplos de meios de proteção ativa: sistema de alarme manual de incêndio, meios de detecção e alarme automáticos de incêndio (detectores de fumaça e temperatura), extintores, hidrantes e chuveiros automáticos (sprinklers), sistema de iluminação e sinalização de emergência e sistemas de controle e exaustão da fumaça.

A proteção passiva corresponde ao conjunto de medidas incorporadas ao sistema construtivo do edifício e que estão em funcionamento durante o uso normal da edificação, ou seja, não necessitam de acionamento para executar sua função, como na proteção ativa. Este tipo de proteção reage passivamente ao desenvolvimento do incêndio de forma a dificultar o seu crescimento e propagação, auxiliando ainda na fuga dos usuários através da resistência conferida aos materiais constituintes da edificação. Mais detalhes deste tipo de proteção serão abordados na sequência do texto.

\section{A.6 Materiais de revestimento contra o fogo}

As propriedades mecânicas dos materiais sofrem reduções devido à elevação de temperatura. Propriedades do aço, tais como sua resistência ao escoamento e módulo de elasticidade, assim como a resistência à compressão do concreto e seu módulo de elasticidade, têm seus valores drasticamente alterados em situações de incêndio, o que pode conduzir o elemento estrutural ou mesmo toda a estrutura ao colapso. 
Com relação às estruturas metálicas, por exemplo, Rocha (2012) afirma que o aço sem revestimento térmico, quando exposto a altas temperaturas, sofre uma rápida redução em suas propriedades mecânicas como consequência de uma de suas propriedades térmicas (condutividade térmica). Sendo assim, a fim de melhorar o desempenho dessas estruturas é necessária a utilização de materiais que apresentem mais resistência ao fogo, tais como os revestimentos contra fogo.

A fim de evitar as perdas de vidas e materiais decorrentes da falha prematura de uma estrutura em situação de incêndio podem ser adotadas duas soluções. A primeira consiste no dimensionamento adequado da estrutura para resistir às temperaturas elevadas e aos esforços decorrentes dessa situação. A segunda opção relaciona-se com a utilização de materiais de revestimento que, devido as suas propriedades térmicas, atuam como proteção contra a ação do fogo, reduzindo ou mesmo retardando os efeitos prejudiciais das chamas sobre o elemento protegido.

Segundo Fakury (1999) apud Regobello (2007), no início das aplicações de materiais de proteção térmica eram empregadas técnicas simples, tais como a execução de alvenarias contornando os pilares ou mesmo a construção de vigas e pilares no interior do concreto (Figura A.5). Porém, atualmente, em Ribeiro (2004) se afirma que estes métodos são pouco usados, devido principalmente ao tempo dispendido para a execução de tais proteções, além da elevação do peso próprio da estrutura.
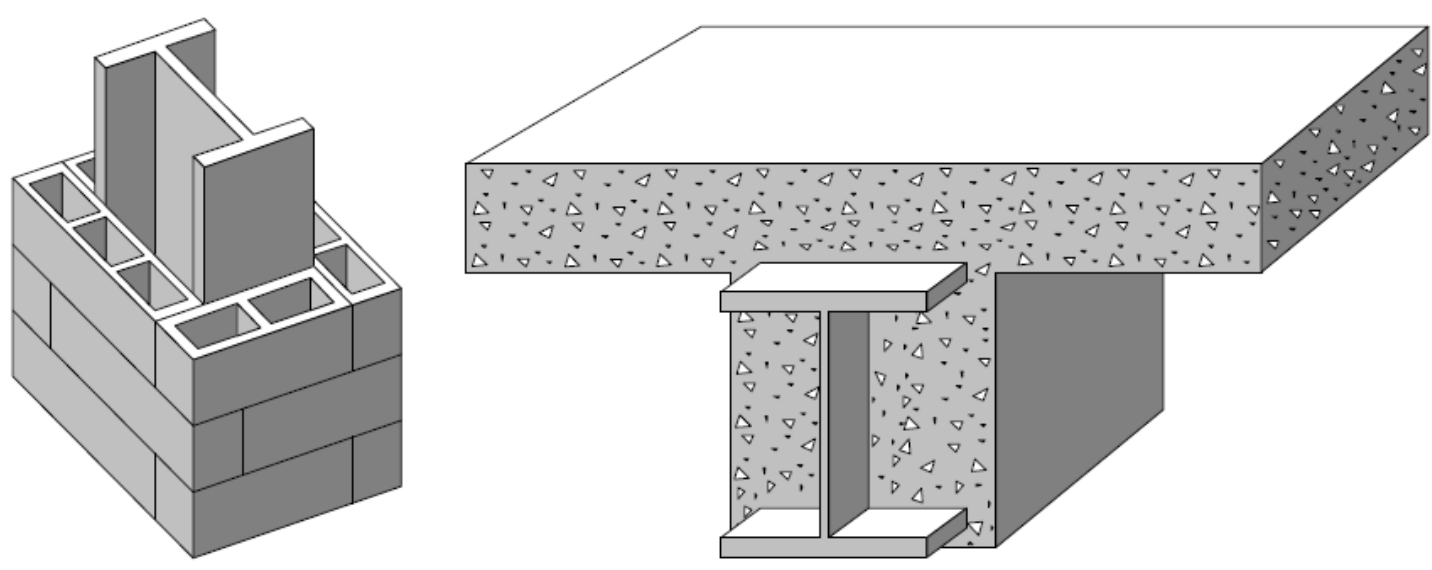

Figura A.5 - Proteções térmicas inicialmente utilizadas em estruturas metálicas.

Fonte: Ribeiro, 2004. 
Segundo Mendes (2004), os materiais de proteção térmica devem apresentar capacidade de proteção térmica quando submetidos a elevadas temperaturas, preservando a sua integridade estrutural durante o incêndio. Tais materiais não podem apresentar riscos à saúde e devem trabalhar solidariamente com a estrutura a qual estão associados, acompanhando os deslocamentos das mesmas e fornecendo uma proteção homogênea.

Nesse contexto, Mendes (2004) afirma que para garantir um bom desempenho, características como baixa massa específica aparente, baixa condutividade térmica e elevado calor específico, devem estar presentes em tais materiais.

\section{A.7 Classificação dos materiais de revestimento contra o fogo}

As proteções térmicas podem ser classificadas quanto ao material constituinte, quanto à morfologia e quanto à técnica de colocação (Fakury (1999) apud Regobello (2007)).

Com relação ao material constituinte, pode-se ter alvenaria, concreto de cimento portland, concreto leve, argamassas à base de cimento, de fibras minerais, de vermiculita ou de gesso, mantas de fibras cerâmicas, de fibras minerais ou de lã de rocha, tintas intumescentes, entre outros. Quanto à morfologia, podem ser do tipo contorno, do tipo caixa com vãos e sem vãos, assim como apresentado pela Figura A.6 e pela Figura A.7.

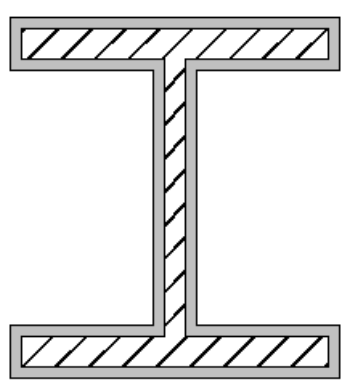

Tipo contorno

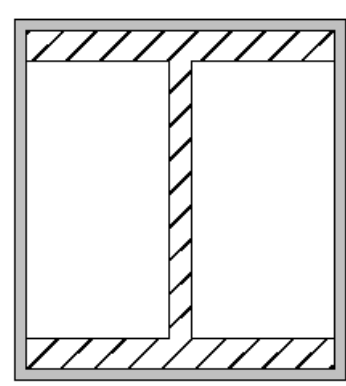

Tipo Caixa

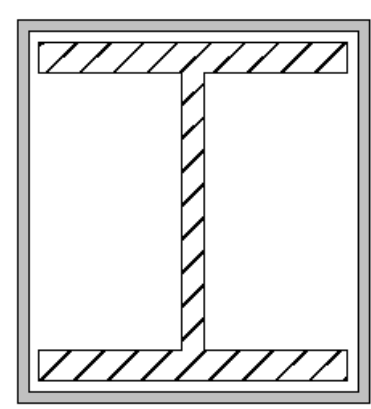

Tipo caixa com vãos

Figura A.6 - Proteção térmica do tipo contorno e do tipo caixa para pilares. 


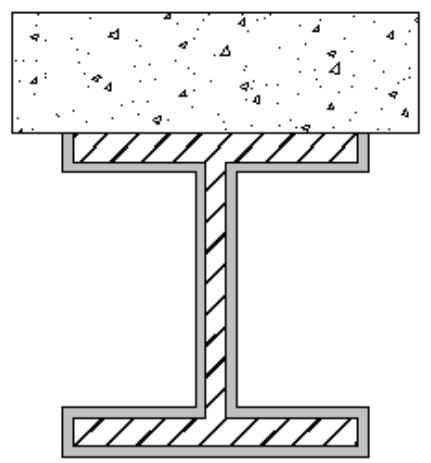

Tipo contorno

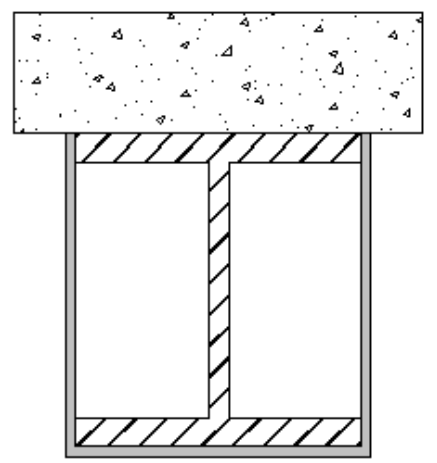

Tipo Caixa

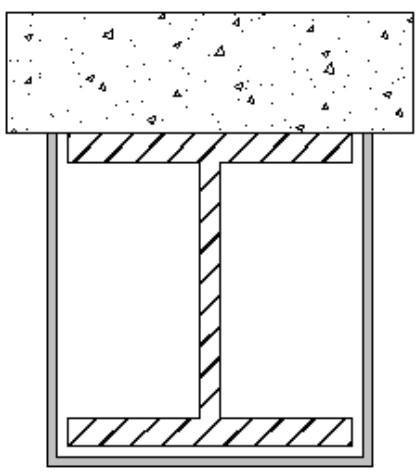

Tipo caixa com

vãos

Figura A.7 - Proteção térmica do tipo contorno e do tipo caixa para vigas.

Por fim, podem ainda ser classificadas quanto à técnica de colocação, na qual são moldadas com fôrmas, aplicadas manualmente (por jateamento), fixadas por dispositivos apropriados ou montadas.

Vale destacar que, segundo Ribeiro (2004), as proteções térmicas do tipo caixa apresentam a maior eficiência térmica em decorrência do confinamento do ar promovido em seu interior e que as proteções constituídas por alvenarias são utilizadas, por exemplo, envolvendo o elemento de aço, formando uma proteção do tipo caixa. Além disso, os concretos aplicados utilizando fôrmas podem constituir tanto proteções do tipo caixa quanto do tipo contorno. 


\section{Apêndice B}

\section{REGISTRO FOTOGRÁFICO}

Figuras B.1 - Soldagem armaduras e termopares:

São mostradas, a seguir, fotografias tiradas no laboratório de estruturas durante a soldagem das armaduras e dos termopares. Essa soldagem fazia parte da preparação das vigas mistas de aço e concreto parcialmente revestidas.
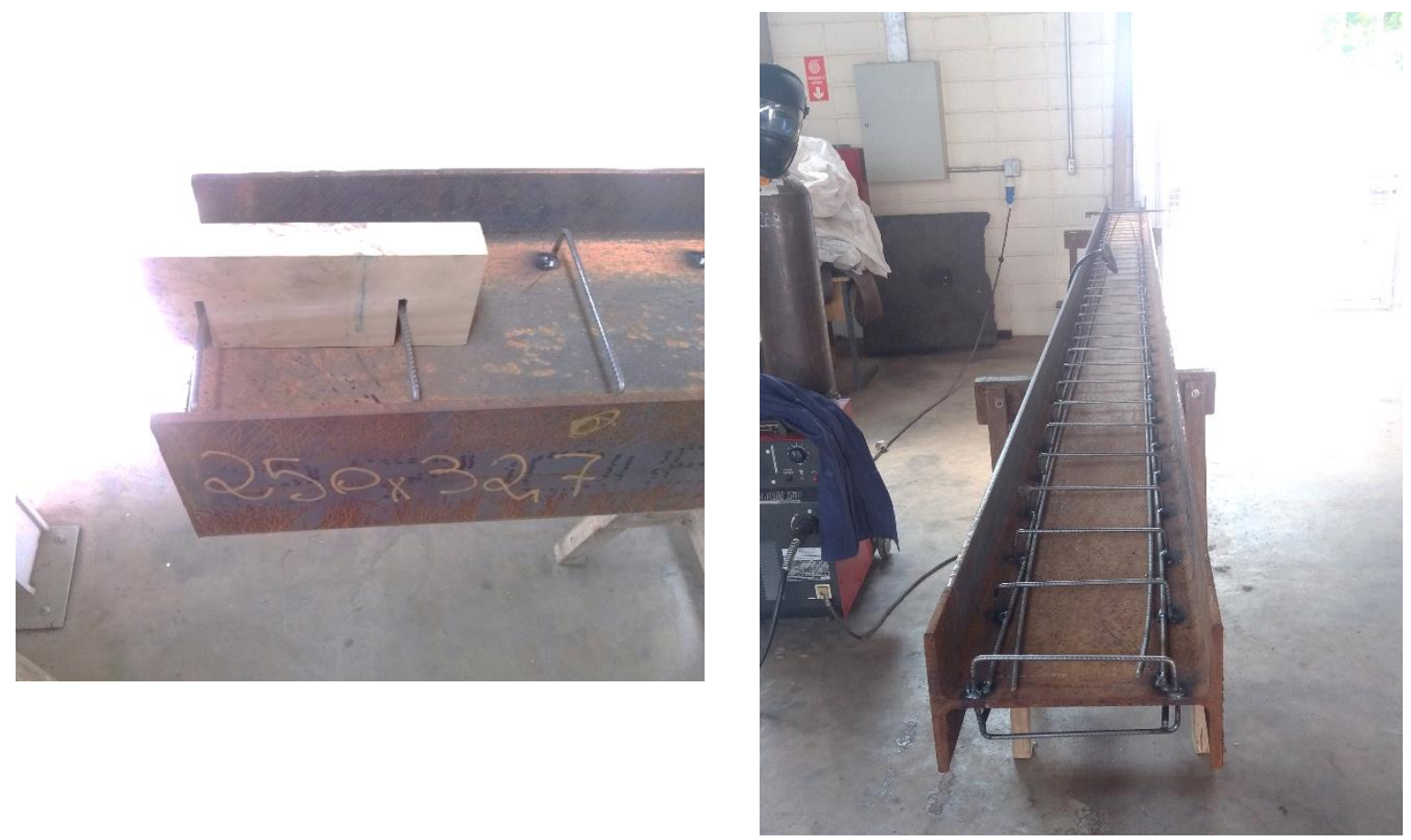

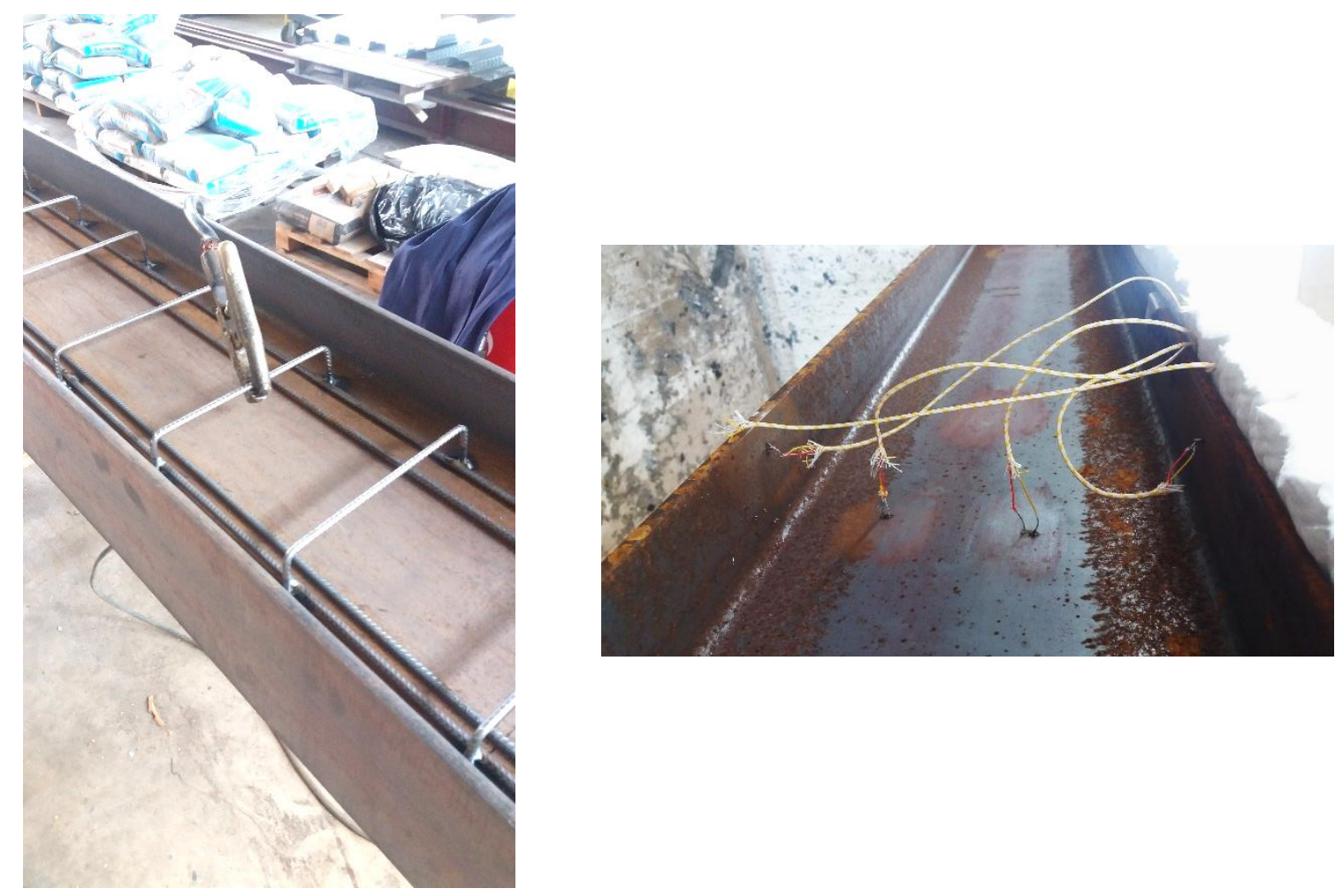

Figuras B.2 - Concretagem:

Abaixo são apresentadas fotografias tiradas durante os dois dias de concretagem, uma vez que a concretagem foi feita em duas etapas com um espaço de 7 dias entre elas.
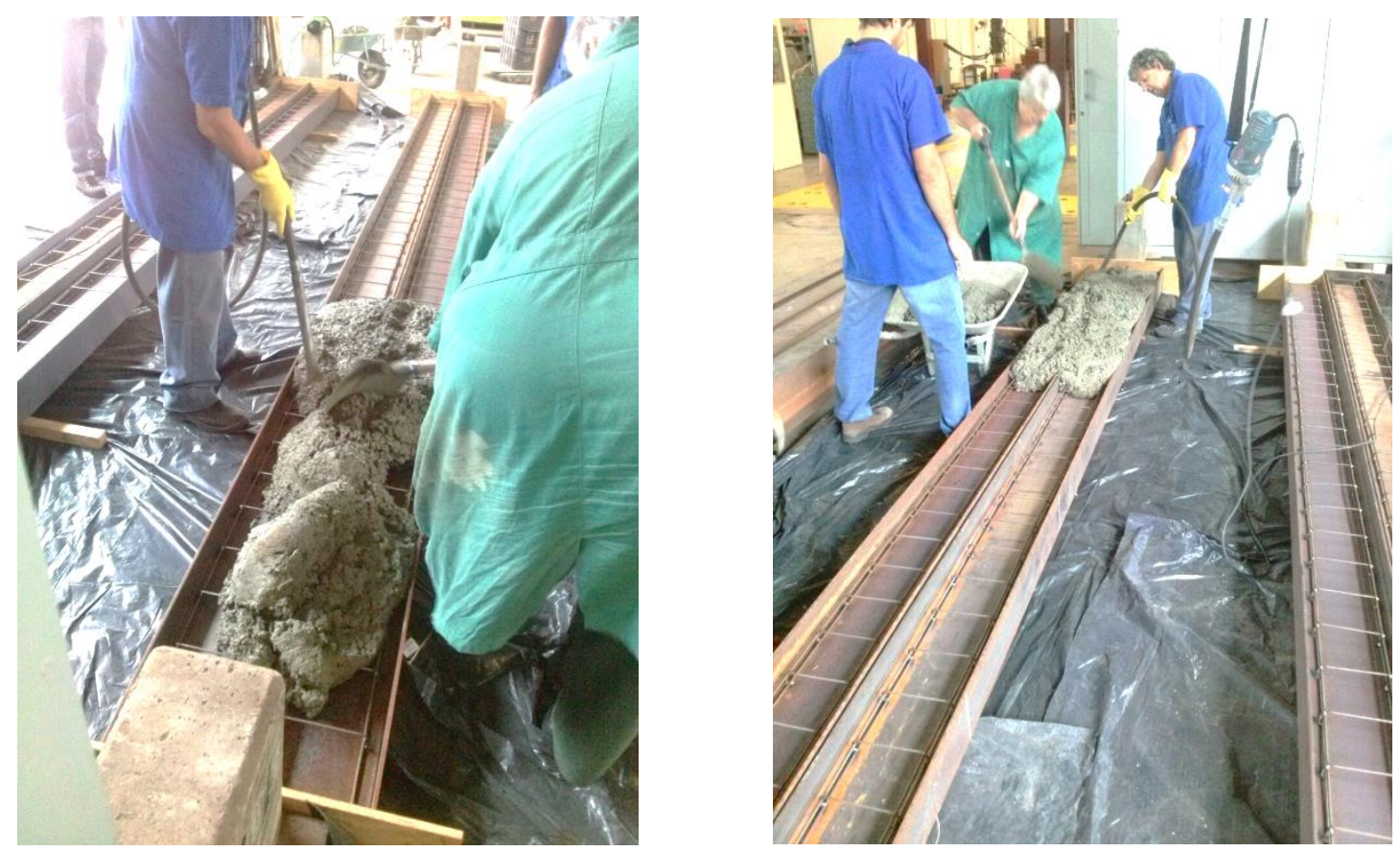

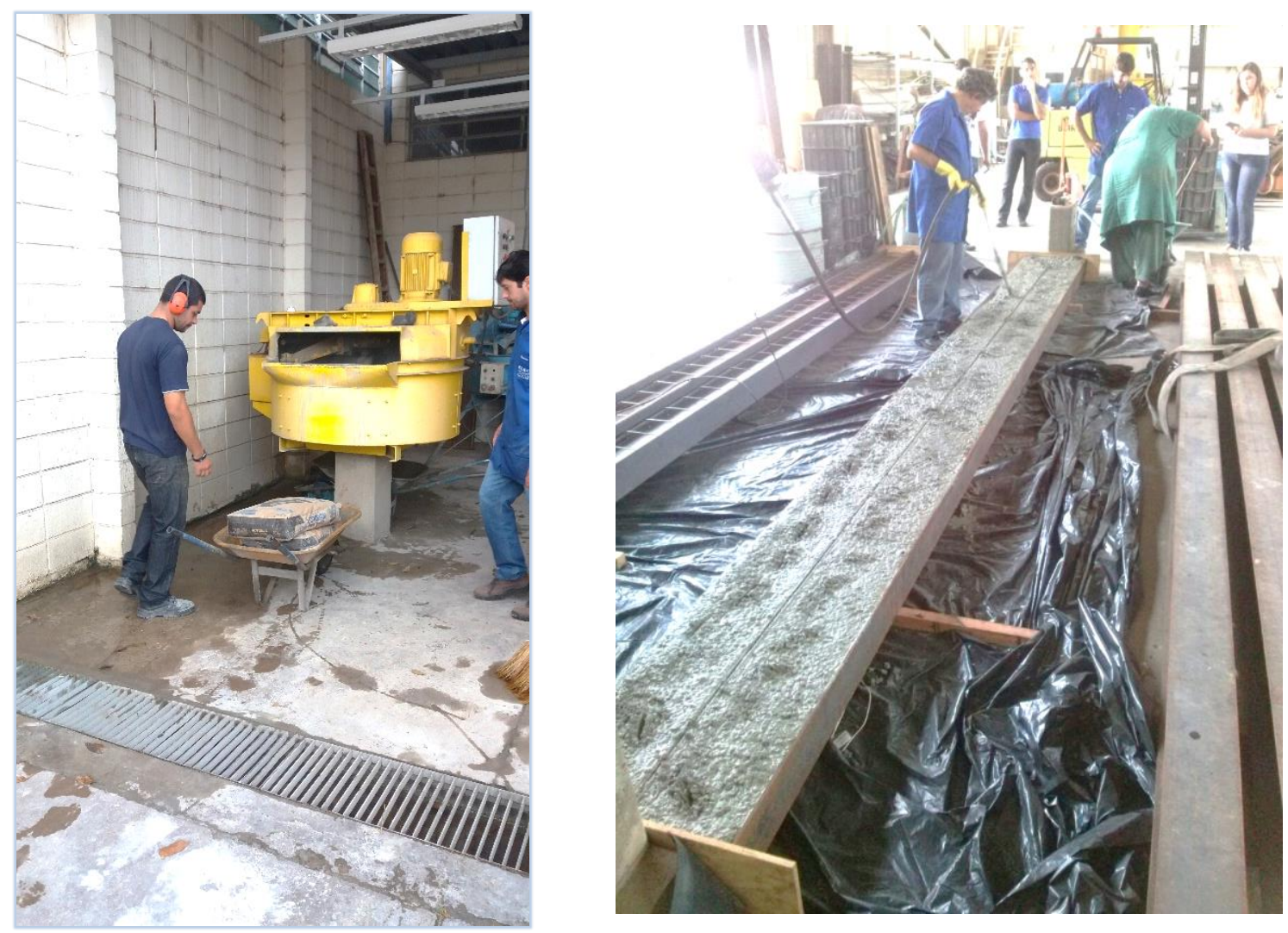

Figuras B.3 - Ensaios em temperatura ambiente:

Seguem fotografias tiradas nos dois ensaios feitos a temperatura ambiente. Um deles na viga metálica e o outro feito na viga mista de aço e concreto parcialmente revesta. Esses ensaios foram realizados com o objetivo de determinar experimentalmente o valor da carga máxima de ruptura das vigas. Esse valor foi posteriormente utilizado nos ensaios em temperatura elevada.

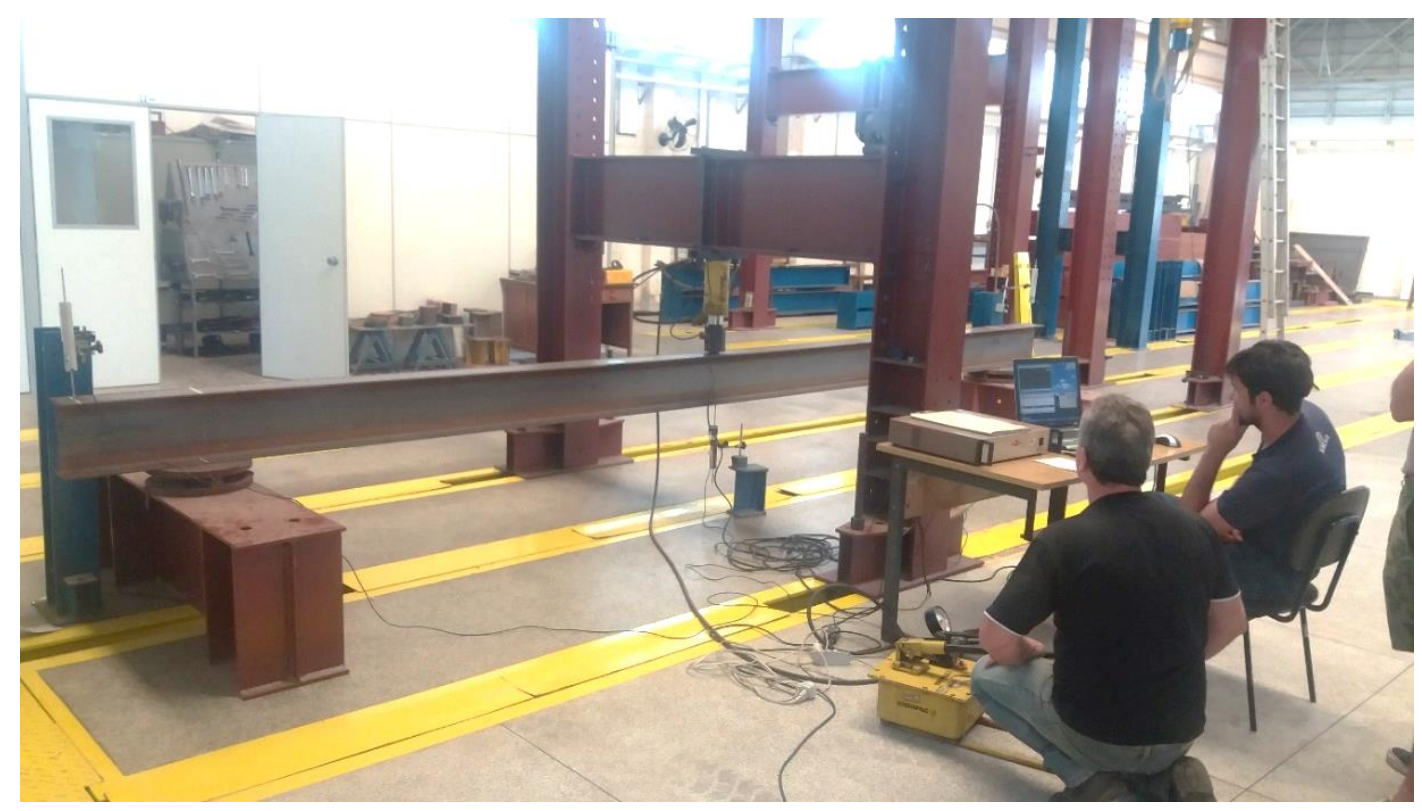



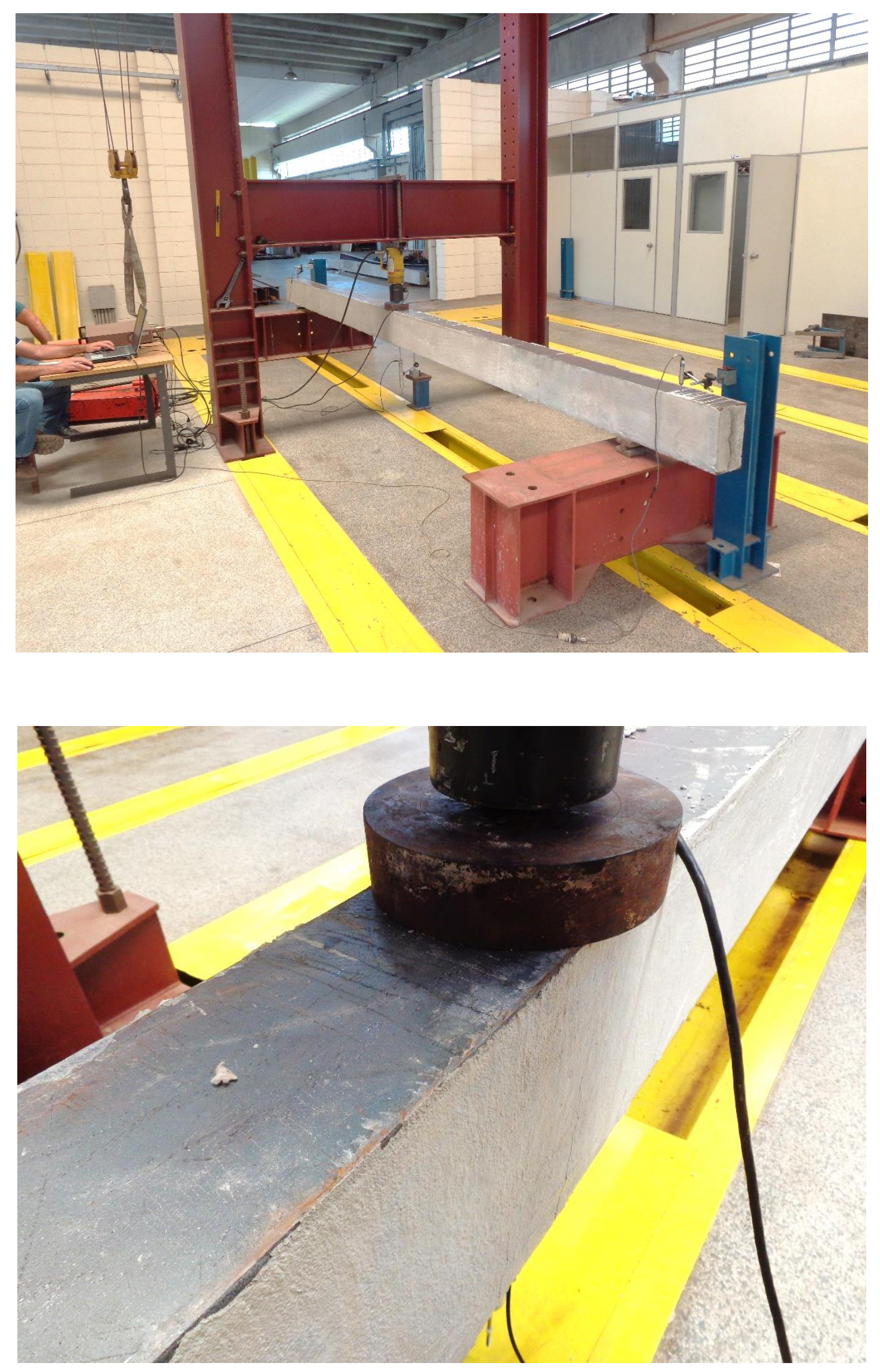
Figuras B.4 - Ensaios temperatura elevada:

As fotos abaixo mostram momentos dos ensaios a temperaturas elevadas. Nelas temos a vista do forno de vários ângulos do laboratório de estruturas, mostrando pontos relevantes dos ensaios (apoios, transdutores, aplicação de carga). Em uma das fotos temos o engenheiro doutor Fábio Martins Rocha (que muito contribuiu para o presente trabalho) realizando a leitura dos dados no computador anexo ao forno durante os ensaios.

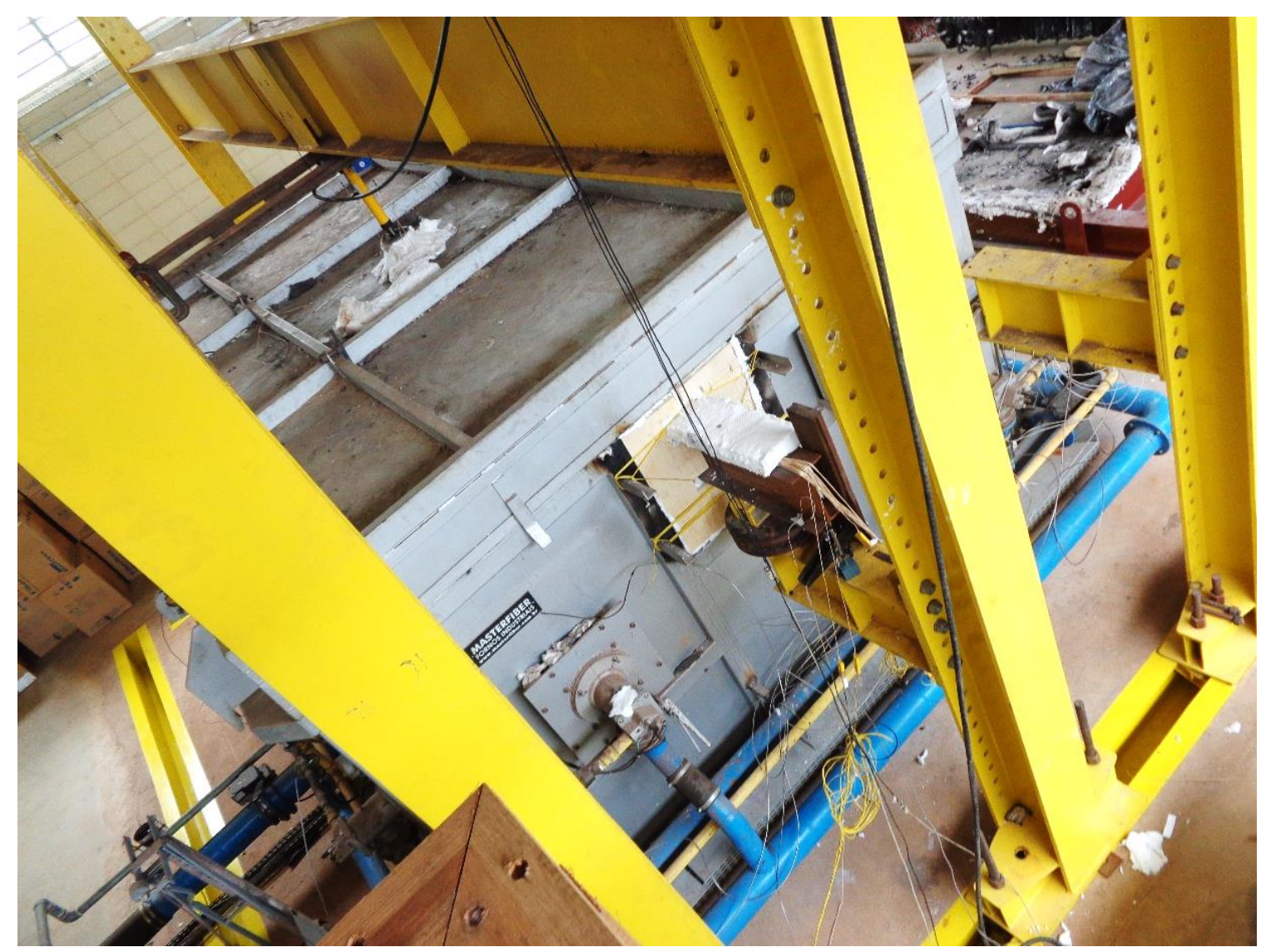



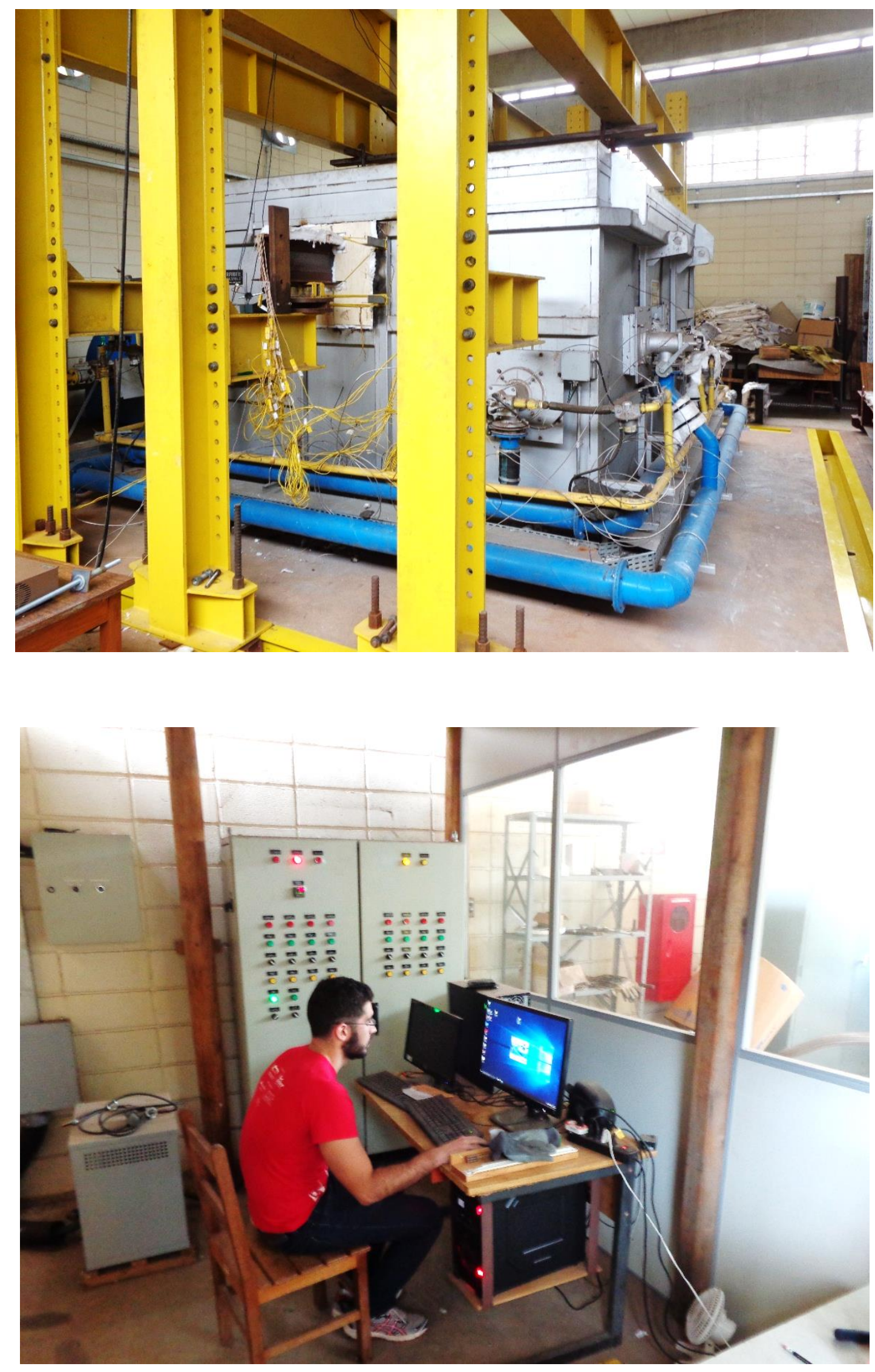


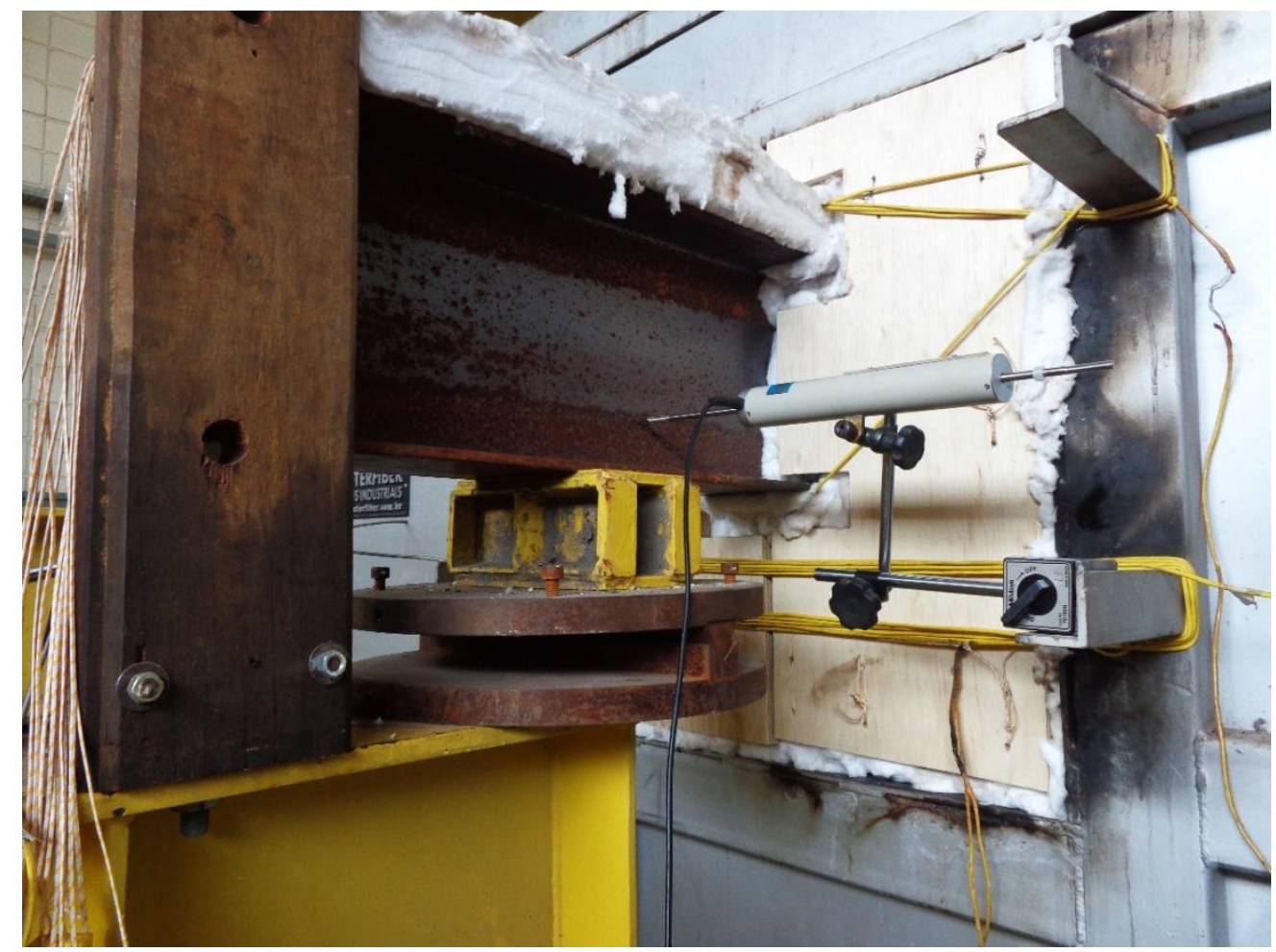

Figuras B.5 - Vigas após os ensaios

Por fim, fotografias tiradas após os ensaios a temperatura elevada, mostrando as vigas sendo retiradas do forno, bem como o estado de deformação delas após os ensaios.

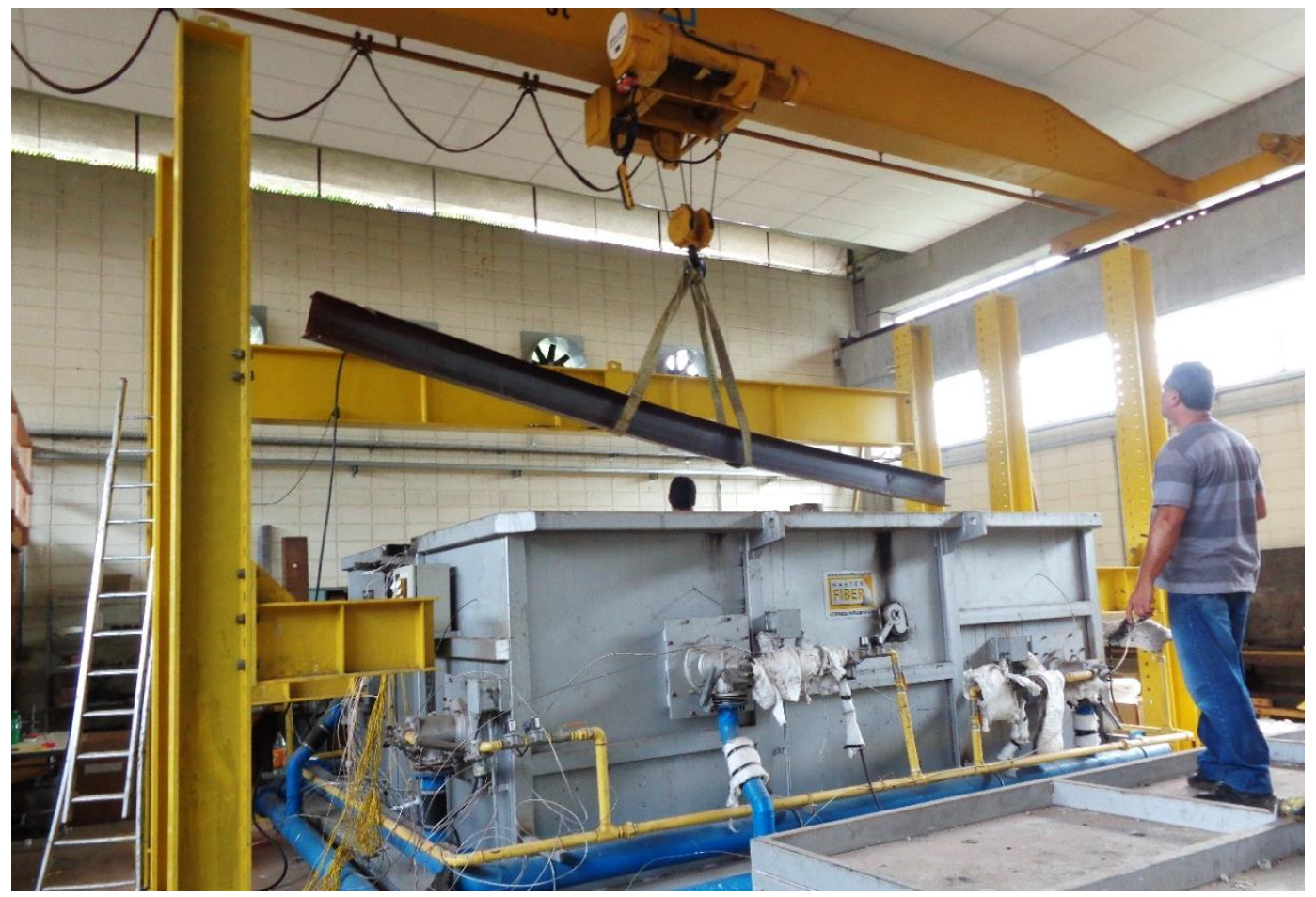



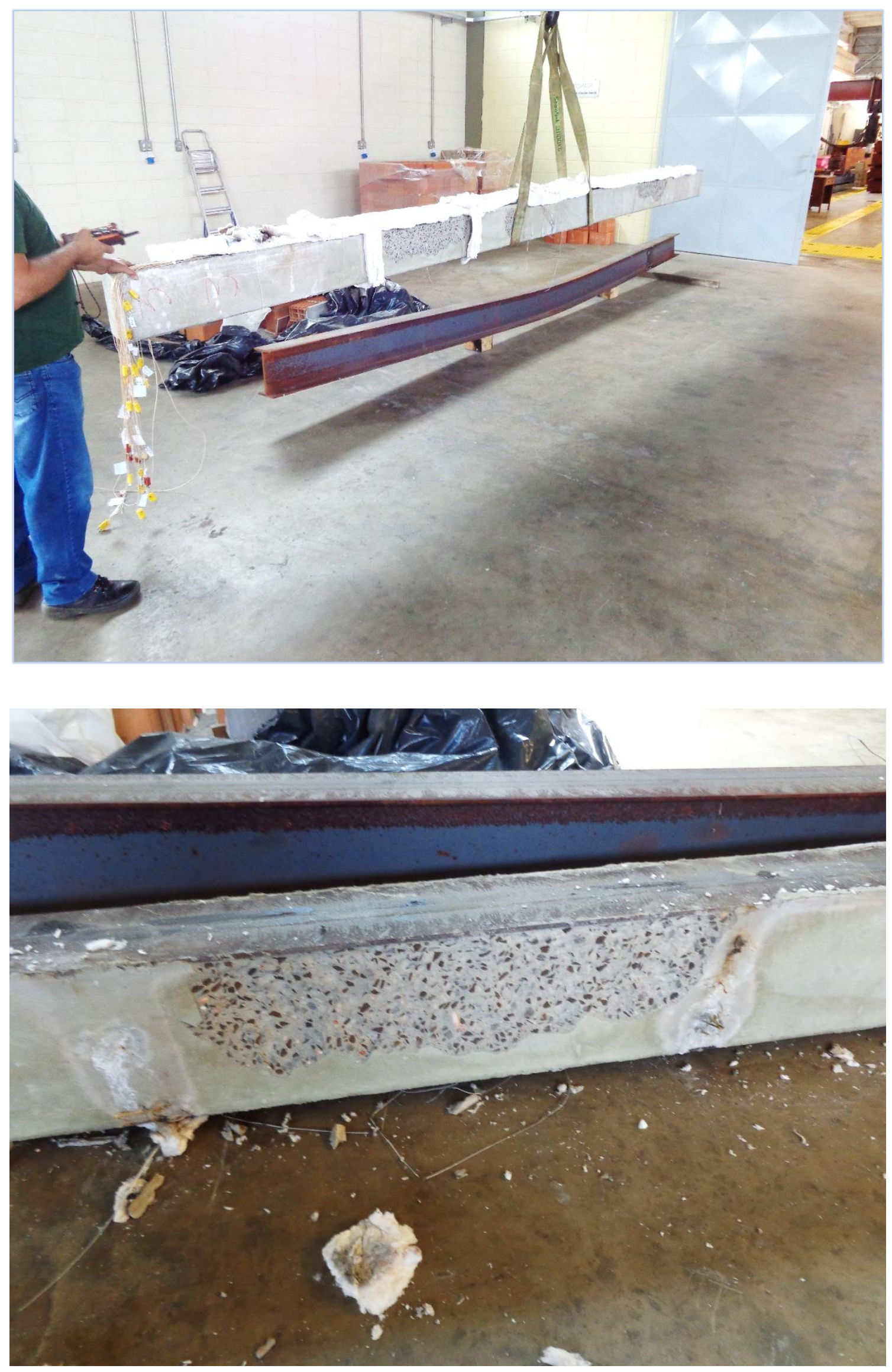

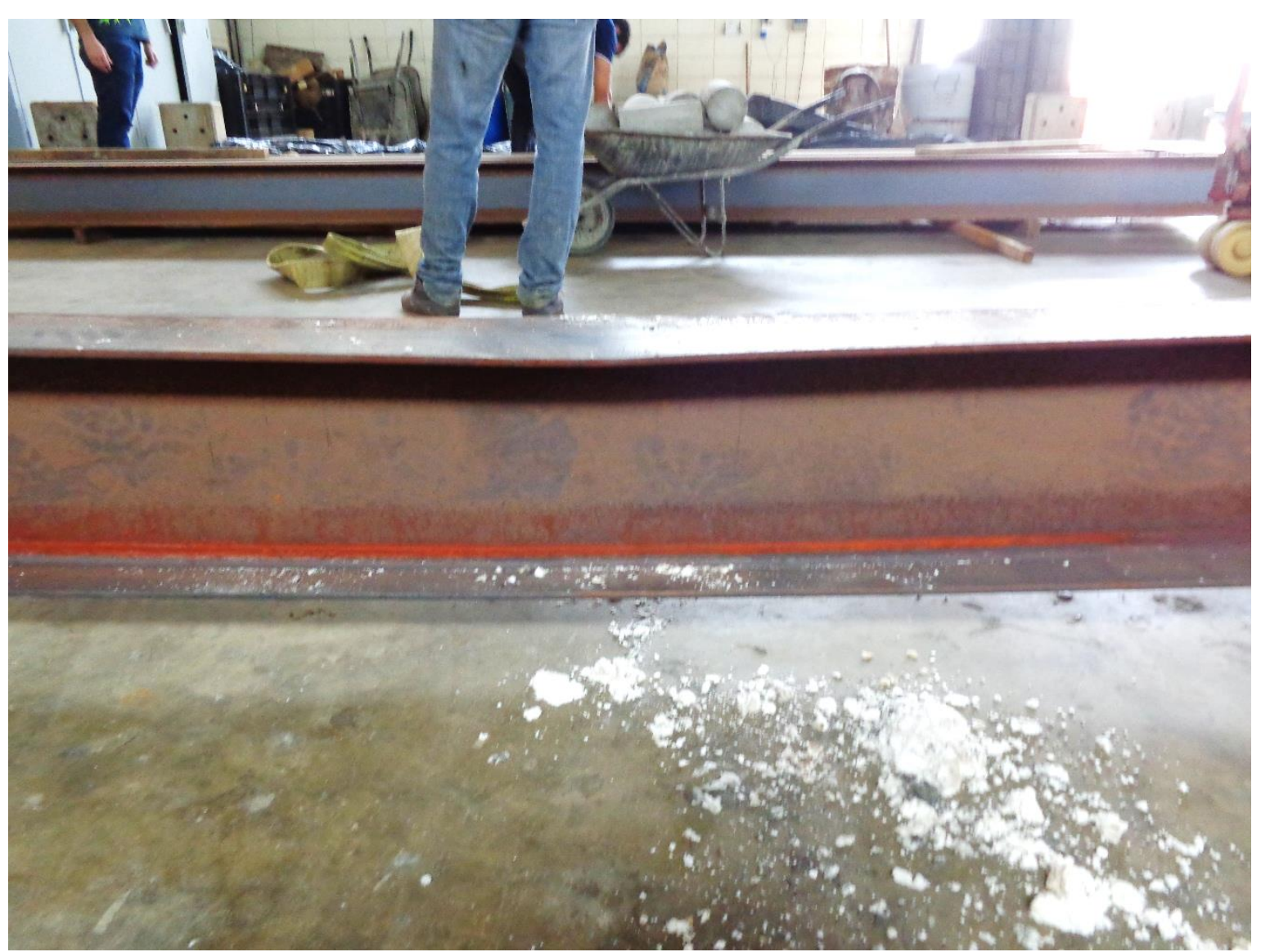